\title{
Proteomic, transcriptomic and epidemiological analysis of adipocyte-secreted proteins'towards a system biological understanding of adipocytes
}

Citation for published version (APA):

Wang, P. (2007). Proteomic, transcriptomic and epidemiological analysis of adipocyte-secreted proteins'towards a system biological understanding of adipocytes. [Doctoral Thesis, Maastricht University]. Datawyse. https://doi.org/10.26481/dis.20070329pw

Document status and date:

Published: 01/01/2007

DOI:

10.26481/dis.20070329pw

Document Version:

Publisher's PDF, also known as Version of record

Please check the document version of this publication:

- A submitted manuscript is the version of the article upon submission and before peer-review. There can be important differences between the submitted version and the official published version of record.

People interested in the research are advised to contact the author for the final version of the publication, or visit the DOI to the publisher's website.

- The final author version and the galley proof are versions of the publication after peer review.

- The final published version features the final layout of the paper including the volume, issue and page numbers.

Link to publication

\footnotetext{
General rights rights.

- You may freely distribute the URL identifying the publication in the public portal. please follow below link for the End User Agreement:

www.umlib.nl/taverne-license

Take down policy

If you believe that this document breaches copyright please contact us at:

repository@maastrichtuniversity.nl

providing details and we will investigate your claim.
}

Copyright and moral rights for the publications made accessible in the public portal are retained by the authors and/or other copyright owners and it is a condition of accessing publications that users recognise and abide by the legal requirements associated with these

- Users may download and print one copy of any publication from the public portal for the purpose of private study or research.

- You may not further distribute the material or use it for any profit-making activity or commercial gain

If the publication is distributed under the terms of Article 25fa of the Dutch Copyright Act, indicated by the "Taverne" license above, 
Proteomic, transcriptomic and epidemiological analysis of adipocyte-secreted proteins

- towards a system biological understanding of adipocytes 
The research described in this thesis was sponsored by The Centre for Human Nutrigenomics, The Netherlands (CHN).

\section{niutín}
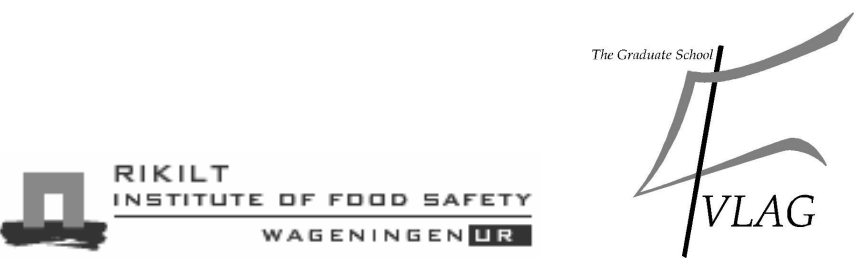

The study presented in this thesis was performed within the Nutrition and Toxicology Research Institute Maastricht (NUTRIM) and RIKILT - Institute of Food Safety, which both participate in the Graduate School VLAG (Food Technology, Agrobiotechnology, Nutrition and Health Sciences), accredited by the Royal Netherlands Academy of Arts and Sciences.

Cover design: Ping Wang

Layout: Ping Wang

Printed by: Datewyse

(C) Ping Wang, 2007

ISBN 978-90-5278-607-0 


\title{
Proteomic, transcriptomic and epidemiological analysis of adipocyte-secreted proteins
}

- towards a system biological understanding of adipocytes

\section{DISSERTATION}

\author{
to obtain the degree of Doctor at \\ the Maastricht University, \\ on the authority of the Rector Magnificus, \\ Prof. Dr. G.P.M.F. Mols, \\ in accordance with the decision of the Board of Deans, \\ to be defended in public \\ on Thursday 29 March 2007 at 16:00 \\ by
Ping Wang
王 萍

born on 27 April 1970 in Shanghai, China

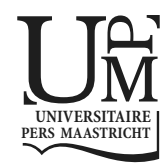




\section{Promotor / Supervisor:}

Prof. Dr. Edwin C.M. Mariman

\section{Co-promotors / Co-supervisors:}

Dr. Jaap Keijer (RIKILT- Institute of Food Safety, Wageningen)

Dr. Johan Renes

\section{Assessment Committee:}

Prof. Dr. Wim H.M. Saris (Chairman)

Prof. Dr. Susanne Klaus (German Institute of Human Nutrition, Potsdam, Germany)

Prof. Dr. Ronald P. Mensink

Prof. Dr. Michael Müller (Wageningen University, Wageningen)

Prof. Dr. Frederik-Jan van Schooten 


\section{Contents}

Chapter 1 .7

Introduction: Adipokines, in a physiological and etiological perspective

Chapter 2 27

Profiling of the secreted proteins during 3T3-L1 adipocyte differentiation leads to the identification of novel adipokines

Chapter 3 47

Insulin modulates the secretion of proteins from mature 3T3-L1 adipocytes: a role for transcriptional regulation

Chapter 4 .65

Absence of an adipogenic effect of rosiglitazone on mature 3T3-L1 adipocytes: increase of lipid catabolism and reduction of adipokine expression

Chapter 5

The circulating PBEF/NAMPT/visfatin level is associated with a beneficial blood lipid profile

Chapter 6 .97

Pigment epithelium-derived factor, a potent anti-angiogenic factor and newly identified adipokine, is associated with obesity, hypertension and impaired glucose metabolism in humans

Chapter 7

General Discussion

Supplementary materials

Summary

Samenvatting 136

Acknowledgements

List of publications .

Curriculum Vita 143 


\section{Introduction: Adipokines, from a physiological and etiological perspective}

P. Wang ${ }^{1,2}$

${ }^{1}$ Functional Genomics Group, Maastricht Proteomics Center, Department of Human Biology, the Nutrition and Toxicology Research Institute Maastricht (NUTRIM), Maastricht University, Maastricht, the Netherlands. ${ }^{2}$ Food Bioactives Group, RIKILTInstitute of Food Safety, Wageningen, the Netherlands. 


\section{Contents}

Obesity 8

Adipose tissue and adipocytes 9

The physiology and the secretion of white adipose tissue 10

The secretory function of adipocytes in the etiology of obesity related disorders ... 16

Outline of the thesis

References

\section{Obesity}

Obesity has reached epidemic proportions globally, affecting persons of virtually all ages in both developed and developing countries, with more than 1 billion adults being overweight, and at least 300 million of them being clinically obese [1]. The prevalence of overweight and obesity is commonly assessed by using the body mass index (BMI), defined as the weight in kilograms divided by the square of the height in meters $\left(\mathrm{kg} / \mathrm{m}^{2}\right)$. A BMI over 25 is defined as overweight, and a BMI over 30 as obese [2].

The rising epidemic of obesity reflects the profound changes in society and in behavioral patterns of communities over recent decades. Although genes are important in determining a person's susceptibility to weight gain [3], the energy balance rather is determined by calorie intake and physical activity [4]. It has been estimated that the genetic factors related to food intake, basal metabolic rate and adipocyte differentiation may contribute 52-75\%, while the environmental factors: life style, psychological factors, and tradition, may provide $25-48 \%$ to the etiology of obesity [5].

Obesity is a major contributor to the global burden of chronic disease and disability [1]. The health consequences of obesity and overweight range from increased risk of premature death, to serious chronic conditions that reduce the overall quality of life. Overweight and obesity lead to adverse metabolic effects on blood pressure, cholesterol, triglycerides and insulin resistance. The non-fatal, but debilitating health problems associated with obesity include respiratory difficulties, osteoarthritis, chronic musculoskeletal problems, skin problems and infertility. The more life-threatening problems fall into four main areas: hypertension and cardiovascular diseases; insulin resistance and type 2 diabetes; certain types of cancers, especially the hormonally related cancers and large-bowel cancers; and gallbladder disease $[1,6]$. In one study in the USA, over half $(53 \%)$ of all deaths in women with a BMI $>29$ could be directly attributed to their obesity [7]. In the global analysis carried out for the World Health Report 2002, approximately $58 \%$ of diabetes, $21 \%$ of ischaemic heart disease and 8$42 \%$ of the cancers mentioned above were attributable to a BMI above 21 [8]. 


\section{Adipose tissue and adipocytes}

Obesity is primarily characterized with increased mass of fat, or adipose tissue. The terms 'fat' and 'adipose tissue' in common usage are almost interchangeable. However, scientifically, in the body composition and metabolism field, 'fat' and 'adipose tissue' are distinct. Fat as one chemically defined component of the body, exists in adipose tissue and other tissues as well. Adipose tissue is composed of not only fat, but also proteins, minerals and water [9]. In normal-weight human subjects adipose tissue constitutes between 10 and $20 \%$ of total body mass in males and between 15 and $25 \%$ in females [10]. Adipose tissue is a specialized loose connective tissue that is extensively laden with adipocytes.

The anatomy of adipose tissue $[9,11]$ shows that some areas of adipose depots are brown, which are termed 'brown adipose tissue' (BAT), while many are white and termed 'white adipose tissue' (WAT). BAT has been found abundantly in small mammals such as rodents, as well as in newborns of larger mammals, including humans. In rodents, all the adipose depots are composed of mixed BAT and WAT in various proportions [11]. In large mammals after birth, BAT gradually disappears from these sites or changes into tissue histologically indistinguishable from WAT. Nevertheless, there is evidence showing that man does have some residual BAT at certain sites but the total amount is rather small $[12,13]$.

WAT and BAT consist of two distinct types of adipocytes, white and brown adipocytes, respectively. Both cell types share the unusual property of accumulation and release of fatty acids that are at the base of their activity. Furthermore they both express the rather specific adrenergic receptor $\beta 3$. However, they have distinct anatomy and functions. White adipocytes [11] are unilocular (with only one big fat droplet), and allow fatty acid accumulation after a meal and distribute fuel (fatty acids) to the organism between meals. Brown adipocytes [14] are multilocular (with multiple fat droplets), and rich in big characteristic mitochondria. Brown adipocyte mitochondria contain uncoupling protein 1 (UCP1), responsible for uncoupling of the oxidative phosphorylation, which in turn is responsible for the thermogenic function of this cell type.

The expanded adipose tissue mass in obesity and overweight is caused by WAT growth through a combination of increasing the size of pre-existing adipocytes (hypertrophy) and de novo adipocyte recruitment (hyperplasia) $[10,15]$. BAT is not the cause of obesity. In fact, it may be useful in counteracting the development of obesity by dispensing the energy [14]. In this thesis, the focus is on WAT only.

In mammals, the adipose tissues form a multi-depot organ, the adipose organ. Following traditional anatomy, adipose tissue can be classified into four categories: subcutaneous adipose tissue, organ-surrounding adipose tissue, interstitial adipose tissue (such as the one infiltrated into muscle tissue) and adipose tissue in bone marrow [9]. Conventionally, adipose tissue is divided into subcutaneous and visceral depots, within the truncal or abdominal region [9, 16]. Various adipose tissue depots may have unique characteristics in metabolism [17]. The weight gain/loss of different depots also may respond differently under the same circumstance [18, 19]. For instance, compared to subcutaneous, visceral adipose tissue may have higher metabolic activity with respect to 
insulin-induced glucose uptake in humans [20]. Mammary gland adipose tissue plays an important role in epithelial cell growth and milk production, whereas bone marrow adipose tissue might participate in hematopoiesis and osteogenesis [21]. Abdominal visceral (intra-abdominal) adipose tissue is regionally present inside the abdominal cavity. Based on magnetic resonance imaging, it has been estimated that men and women contain about $15-18 \%$ and $7-8 \%$ of their total body fat, respectively within the abdominal cavity [22]. Although this depot is a minor part, it is particularly suspected to have a strong link with insulin resistance and coronary heart disease [23]. Conversely, critical reviews [22, 24], based on in vivo studies, cannot conclude that abdominal visceral depot is the major player in causing insulin resistance and the associated metabolic syndrome, but rather suggest that the subcutaneous adipose depot, which usually outweighs the abdominal visceral depot by several-fold, probably plays the major role.

In addition to adipocytes, adipose tissue contains other cell types. It is endowed with a well-organized vasculature [25] and is highly innervated [26]. Blood vessels and nerves link adipose tissue closely to the whole body for metabolic regulation, which is further explained below. In addition, there are other types of non-fat cells (stromal-vascular cells) that are present in adipose tissue, including preadipocytes, the adipocyte precursor cells [27], and, in the obese situations, infiltrated macrophages from the blood [28-30].

Preadipocytes have undergone determination and can further undergo commitment to adipocytes. Adipocyte differentiation, which is the development of adipocytes from preadipocytes and is also termed 'adipogenesis' [31], leads to the hyperplasia of adipose tissue. Via differentiation, dedifferentiation/transdifferentiation and apoptosis/necrosis, the numbers of preadipocytes and adipocytes within adipose tissue are in dynamic change, in response to the nutrition state [32], environmental change [33], pregnancy and lactation [34], drug medication [35, 36] and the adiposity of the cells [30]. The identity of preadipocytes of humans is still under debate. It has been suggested that preadipocytes stem from fibroblasts [37], mesenchymal stem cells [38], or endothelial cell progenitors $[34,39,40]$.

\section{The physiology and the secretion of white adipose tissue}

White adipose tissue is regarded as an active energy reservoir and a source of hormones, and has a passive role as body insulator.

The triglycerides stored in adipose tissue compose an enormous reservoir of metabolic fuel. Triglycerides constitute up to $85 \%$ of the weight of white adipose tissue [41]. In a typical man, the adipose tissue contains $83 \%$ of the whole body energy, and $99.9 \%$ of the energy is stored as triglycerides [42]. White adipose tissue is specialized for the esterification of fatty acids and for their release from triglycerides. Adipocytes allow extra fuel to be stored as triglycerides during calorie abundance and facilitate retrieval during periods of food shortage and calorie deficit (e.g., fasting, starvation, long-term exercise) [43].

In human adipose tissue, the capacity for de novo lipogenesis appears to be low compared with rodent adipose tissue [44] and the contribution of de novo lipogenesis to 
metabolism generally appears not to be significant, except under conditions of overfeeding with a high-carbohydrate diet $[45,46]$. Normally in humans, the liver is the major site for de novo fatty acid synthesis and de novo lipogenesis. Dietary triglycerides and de novo synthesized triglycerides are transported to the adipose tissue in lipoprotein particles, such as very low density lipoproteins. Triglycerides are not directly taken up by adipocytes; rather, they are first hydrolyzed by an extracellular lipoprotein lipase (LPL). After the fatty acids enter the cell, the principal task of adipose tissue is to activate these fatty acids and transfer the resulting CoA derivatives to glycerol in the form of glycerol 3-phosphate. This essential intermediate in lipid biosynthesis mainly comes from glycolysis [47]. Thus, glucose is important for adipocytes to synthesize triglycerides. During lipolysis the triglycerides within adipocytes are hydrolyzed to glycerol and non-esterified fatty acids (NEFAs). The major rate-limiting factor for lipolysis is hormone-sensitive lipase (HSL), but additional lipases such as adipose tissue triglyceride lipase may also play a role. NEFAs as energy substrates are released into the circulation and bind to albumins. They are oxidized, mainly in skeletal muscle, to provide energy. In addition, NEFAs are signaling molecules and substrates for lipoprotein production by the liver [48].

Under normal conditions, the adipocytes are able to fine-tune the balance between the pathways of synthesis (lipogenesis) and breakdown (lipolysis) of triglycerides in response to physiological needs. Through its triglycerides-storing capacity, the adipocytes limit an abnormal increase in plasma NEFAs and keep energy homeostasis. The functions of adipose tissue are regulated by multiple external influences such as autonomic nervous system activity, the rate of blood flow and the delivery of a complex mixture of substrates and hormones into the plasma. The regulation of adipocytes function, in many ways, is species specific. Also gender differences exist with regard to fat mass, fat distribution, regional response and lipolysis rate [48]. Two reviews [43, 49] have provided an excellent overview on the regulation of adipose tissue function. Table 1 summarizes the external key regulators and corresponding process with regard to the function of adipose tissue.

In addition, adipose tissue is capable to modify its own function (autocrine and paracrine) and to participate in the regulation of total body physiology (endocrine) through its secretory function (Figure 1). The complex secretory function of adipocytes is closely integrated into the overall physiological and metabolic control of adipose tissue. Some of the factors secreted by the adipocytes exert local autocrine and paracrine actions, mainly affecting adipose tissue remodeling, adipogenesis, and angiogenesis and are not found in the circulation. Other factors allow the adipocyte to initiate potent feedback actions in the regulation of appetite, food intake, glucose disposal, and energy expenditure.

White adipose tissue is a major secretory organ, particularly through the release of fatty acids during fasting. The identification of leptin [50] led to the recognition that white adipose tissue also has an important endocrine function. To address the biologically active proteins secreted from adipocytes, a term 'adipocytokines' was invented in 1999 [51]. Although many of these molecules do relate to inflammation, this can not cover the broad range of functions. Therefore, this term tends to be replaced by 
'adipokines'[52]. 'Adipokines' are often used for adipose tissue derived molecules [49, 51]. However, other cell types in adipose tissue contribute to the secreted proteins as well. Recently, a considerable number of known 'adipokines', especially inflammation related ones, were found to be mainly from stromal vascular and matrix fractions of adipose tissue, but not from adipocytes [28, 53-58]. Therefore, in a more stringent definition, adipokine applies to only adipocyte-specific or enriched secreted proteins [59]. Nevertheless, a long list of proteins that are named as 'adipokines' appear in the literature, with mixed definitions. Apparently, it is easy to use a broad definition, referring to all secreted proteins and peptides from adipocytes, without having to identify the protein function and to determine the secretion level. Table 2 summarizes briefly the known secreted molecules from adipocytes and adipose tissue, which vary from lipids to proteins and peptides. They act in autocrine, paracrine and/or endocrine manner, and have a function in adipocyte differentiation, energy metabolism, lipid uptake and transport, immune response and inflammation, vasculature and neuron development, and extracellular matrix remodeling. Four excellent reviews [41, 59-61] are recommended for detailed overview on adipokines.

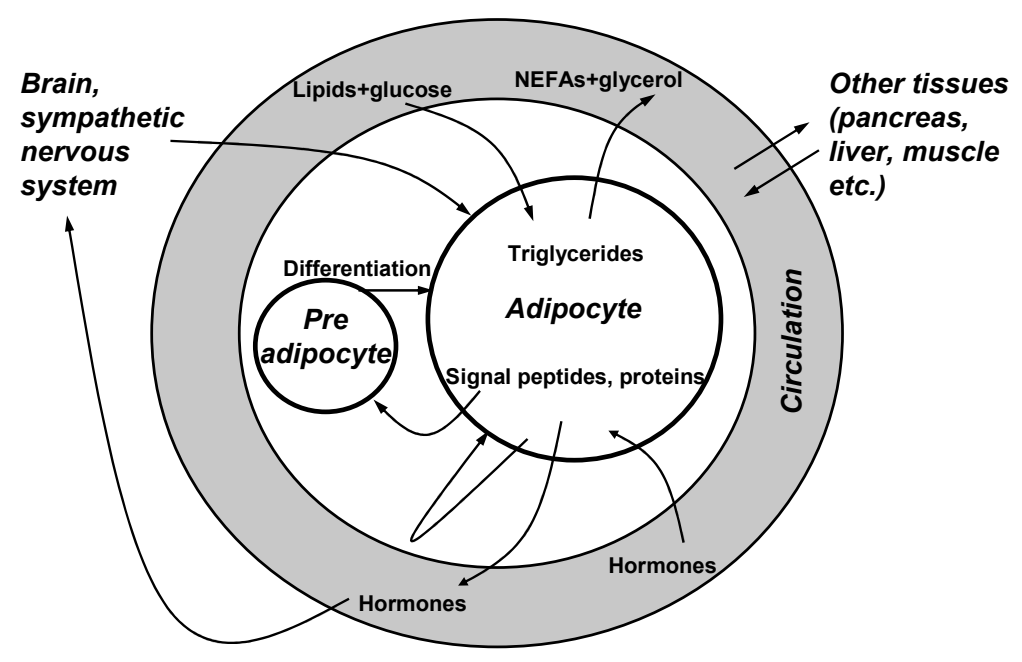

Figure 1. Adipose tissue functions and regulations 
Table 1. External regulators of adipose tissue function

\begin{tabular}{|c|c|c|c|}
\hline Level & Regulator & Process & Note \\
\hline \multicolumn{4}{|c|}{ Differentiation of preadipocytes into adipocytes } \\
\hline \multirow[t]{4}{*}{ hormone } & $\begin{array}{l}\text { insulin/Insulin-like } \\
\text { growth factor-I } \\
\text { (IGF-I) }\end{array}$ & $\begin{array}{l}\text { stimulate differentiation, possibly through } \\
\text { activating ras and/or PKB pathways [31], and } \\
\text { also through SREBP-1c pathway [62] }\end{array}$ & \\
\hline & glucocorticoids & $\begin{array}{l}\text { stimulate differentiation [63] through activating } \\
\text { glucocorticoid receptor, and maybe also } \\
\text { SREBP-1c pathway. }\end{array}$ & \\
\hline & growth hormone & $\begin{array}{l}\text { may stimulate preadipocytes proliferation [64] } \\
\text { and promote differentiation }\end{array}$ & $\begin{array}{l}\text { in rodents, } \\
\text { in vitro }\end{array}$ \\
\hline & prolactin & may promote differentiation [65] & $\begin{array}{l}\text { in rodents, } \\
\text { in vitro }\end{array}$ \\
\hline nutritional factors & free fatty acids & $\begin{array}{l}\text { stimulate differentiation, through derivative } \\
\text { prostaglandin } J_{2} \text { activating PPAR } \gamma \text { pathway [66] }\end{array}$ & \\
\hline drug & $\begin{array}{l}\text { thiazolidinediones } \\
\text { (TZDs) }\end{array}$ & $\begin{array}{l}\text { stimulate differentiation, through activation of } \\
\text { the PPAR } \gamma \text { pathway [67] }\end{array}$ & \\
\hline \multicolumn{4}{|c|}{ Adipocyte trans-differentiation } \\
\hline environment & cold exposure & white into brown adipocytes [11] & in rodents \\
\hline environment & warm exposure & brown into white adipocytes [11] & in rodents \\
\hline drug & adrenegic drugs & white into brown adipocytes [68] & in rodents \\
\hline \multicolumn{4}{|l|}{ Lipogenesis } \\
\hline \multirow[t]{5}{*}{ hormone } & insulin & $\begin{array}{l}\text { activates lipoprotein lipase and the pathways of } \\
\text { esterification [48] }\end{array}$ & \\
\hline & sex steroids & $\begin{array}{l}\text { (inhibitory) regulate the amount and distribution } \\
\text { of adipose tissues [69] }\end{array}$ & \\
\hline & glucocorticoids & $\begin{array}{l}\text { stimulate lipogenesis mediated in part at the } \\
\text { level of the central nervous system [70] }\end{array}$ & \\
\hline & growth hormone & $\begin{array}{l}\text { decreases lipogenesis by inhibiting lipoprotein } \\
\text { lipase activity [71] }\end{array}$ & \\
\hline & prolactin & $\begin{array}{l}\text { may decrease lipogenesis by inhibiting } \\
\text { lipoprotein lipase activity [65] }\end{array}$ & \\
\hline blood flow & feeding & increases substrate (triglycerides) delivery [49] & \\
\hline \multirow[t]{2}{*}{ nutritional factors } & $\begin{array}{l}\text { eicosapentaenoic } \\
\text { acid (EPA), } \\
\text { docosahexaenoic } \\
\text { acid (DHA) }\end{array}$ & $\begin{array}{l}\text { reduce adiposity through the biogenesis of } \\
\text { mitochondria and increase fatty acids catabolism } \\
{[19,72]}\end{array}$ & \\
\hline & flavonoids & $\begin{array}{l}\text { reduce adiposity through the biogenesis of } \\
\text { mitochondria and increase of fatty acids } \\
\text { catabolism }[73,74]\end{array}$ & $\begin{array}{l}\text { in rodents, } \\
\text { BAT may } \\
\text { play role }\end{array}$ \\
\hline \multicolumn{4}{|l|}{ Lipolysis } \\
\hline neurotransmitter & $\begin{array}{l}\text { catecholamines } \\
\text { (noradrenaline, } \\
\text { adrenaline) }\end{array}$ & $\begin{array}{l}\text { active } \beta \text {-adrenegic receptors, stimulate lipolysis } \\
\text { by activation of HSL through cAMP-PKA- } \\
\text { phosphorylation }[26,43]\end{array}$ & \\
\hline \multirow[t]{2}{*}{ hormone } & insulin & $\begin{array}{l}\text { inhibits lipolysis by inhibiting HSL through } \\
\text { dephosphorylation [48] }\end{array}$ & \\
\hline & growth hormone & increases lipolysis [71] & \\
\hline blood flow & fasting & $\begin{array}{l}\text { supports NEFAs release by increasing plasma } \\
\text { albumin supply [49] }\end{array}$ & \\
\hline
\end{tabular}


Table 2. Factors secreted from adipose tissue and adipocytes

\begin{tabular}{|c|c|c|c|c|c|}
\hline & $\begin{array}{l}\text { Functional } \\
\text { category }\end{array}$ & Factor & $\begin{array}{l}\text { Action } \\
\text { manner }\end{array}$ & Functions & $\begin{array}{l}\text { Source inside } \\
\text { adipose tissue }\end{array}$ \\
\hline \multirow{7}{*}{$\frac{n}{2}$} & $\begin{array}{l}\text { non-esterified } \\
\text { fatty acids }\end{array}$ & & autocrine & $\begin{array}{l}\text { stimulate lipids uptake and } \\
\text { metabolism [60] }\end{array}$ & adipocytes \\
\hline & & & paracrine & $\begin{array}{l}\text { enhance adipocyte differentiation } \\
{[75]}\end{array}$ & \\
\hline & & & $\begin{array}{l}\text { endocrine/ } \\
\text { paracrine }\end{array}$ & $\begin{array}{l}\text { affect insulin secretion and } \\
\text { sensitivity [76] }\end{array}$ & \\
\hline & monoglyceride & monobutyrin & paracrine & pro-angiogenic [77] & adipocytes \\
\hline & eicosanoids & $\begin{array}{l}\text { prostaglandin } \\
\mathrm{E}_{2}, \mathrm{I}_{2}\end{array}$ & $\begin{array}{l}\text { autocrine/ } \\
\text { paracrine? }\end{array}$ & $\begin{array}{l}\text { enhance adipocyte differentiation } \\
\text { [78] }\end{array}$ & adipocytes \\
\hline & $\begin{array}{l}\text { steroid } \\
\text { hormones }\end{array}$ & $\begin{array}{l}\text { sex hormones } \\
\text { (estrogens, } \\
\text { androgens) }\end{array}$ & $\begin{array}{l}\text { endocrine/ } \\
\text { autocrine? }\end{array}$ & $\begin{array}{l}\text { change local bioactivity of sex } \\
\text { hormone and associated with } \\
\text { reduced fertility [60]. }\end{array}$ & adipocytes \\
\hline & & cortisol, cotisone & $\begin{array}{l}\text { endocrine/ } \\
\text { autocrine? }\end{array}$ & $\begin{array}{l}\text { change glucocorticoid local } \\
\text { bioactivity [60] }\end{array}$ & adipocytes \\
\hline \multirow{10}{*}{$\frac{0}{0}$} & $\begin{array}{l}\text { energy } \\
\text { metabolism }\end{array}$ & leptin & $\begin{array}{l}\text { endocrine } \\
\text { (brain) }\end{array}$ & $\begin{array}{l}\text { acts through sympathetic nervous } \\
\text { system, inhibits feeding and } \\
\text { increases energy expenditure in } \\
\text { rodents. An indicator of starvation } \\
\text { but not a satiety factor in humans } \\
\text { [79] }\end{array}$ & adipocytes \\
\hline & & adiponectin & endocrine & $\begin{array}{l}\text { insulin sensitizing, stimulates fatty } \\
\text { acid and glucose catabolism, body } \\
\text { energy requirement indicator [80] }\end{array}$ & adipocytes \\
\hline & & resistin & endocrine? & $\begin{array}{l}\text { against insulin sensitivity in liver } \\
\text { in rodents, unknown function in } \\
\text { human [81] }\end{array}$ & $\begin{array}{l}\text { in rodents mainly } \\
\text { from adipocytes, } \\
\text { but from } \\
\text { macrophages in } \\
\text { humans }\end{array}$ \\
\hline & & visfatin & endocrine? & $\begin{array}{l}\text { might mimic insulin action on } \\
\text { glucose metabolism in vitro and in } \\
\text { rodents, but might not relate to } \\
\text { insulin action in humans }[82,83]\end{array}$ & $\begin{array}{l}\text { ubiquitous, may } \\
\text { not secreted } \\
\text { mainly from } \\
\text { adipocytes }\end{array}$ \\
\hline & \multirow{5}{*}{$\begin{array}{l}\text { lipid uptake } \\
\text { and transport }\end{array}$} & lipoprotein lipase & autocrine & mediates lipid uptake $[84,85]$ & adipocytes \\
\hline & & $\begin{array}{l}\text { acylation } \\
\text { stimulating } \\
\text { protein }\end{array}$ & $\begin{array}{l}\text { autocrine/ } \\
\text { paracrine }\end{array}$ & $\begin{array}{l}\text { increases lipogenesis and inhibits } \\
\text { lipolysis [76] }\end{array}$ & adipocytes? \\
\hline & & $\begin{array}{l}\text { fasting-induced } \\
\text { adipose factor }\end{array}$ & $\begin{array}{l}\text { autocrine/ } \\
\text { paracrine? }\end{array}$ & $\begin{array}{l}\text { inhibits lipoprotein lipase, and } \\
\text { decreases adiposity in rodents[86] }\end{array}$ & adipocytes \\
\hline & & $\begin{array}{l}\text { cholesteryl ester } \\
\text { transfer protein }\end{array}$ & $\begin{array}{l}\text { autocrine/ } \\
\text { paracrine }\end{array}$ & $\begin{array}{l}\text { mediates selective uptake of high } \\
\text { density lipoprotein cholesteryl } \\
\text { esters by adipose tissue [87] }\end{array}$ & adipocytes \\
\hline & & $\begin{array}{l}\text { retinol binding } \\
\text { protein }\end{array}$ & endocrine? & $\begin{array}{l}\text { may interfere with insulin action } \\
\text { in liver and muscle [88] }\end{array}$ & adipocytes \\
\hline & cytokines & $\begin{array}{l}\text { tumor necrosis } \\
\text { factor } \alpha\end{array}$ & $\begin{array}{l}\text { autocrine/ } \\
\text { paracrine }\end{array}$ & $\begin{array}{l}\text { pro-inflammatory cytokine, } \\
\text { induces apoptosis, decreases } \\
\text { lipogenesis and stimulates } \\
\text { lipolysis, regulates the production } \\
\text { of other cytokines [52] }\end{array}$ & $\begin{array}{l}\text { mainly not from } \\
\text { adipocytes }\end{array}$ \\
\hline
\end{tabular}


Table 2. Factors secreted from adipose tissue and adipocytes (continued)

\begin{tabular}{|c|c|c|c|c|c|}
\hline & $\begin{array}{l}\text { Functional } \\
\text { category }\end{array}$ & Factor & $\begin{array}{l}\text { Action } \\
\text { manner }\end{array}$ & Functions & $\begin{array}{l}\text { Source inside } \\
\text { adipose tissue }\end{array}$ \\
\hline \multirow{15}{*}{ 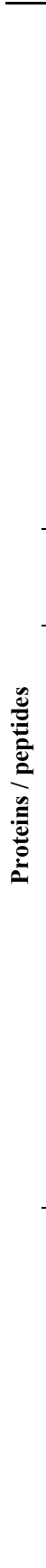 } & \multirow[t]{3}{*}{ cytokines } & interleukin-6 & $\begin{array}{l}\text { endocrine/ } \\
\text { autocrine/ } \\
\text { paracrine }\end{array}$ & $\begin{array}{l}\text { pro-inflammatory cytokine, } \\
\text { decreases lipogenesis, stimulates } \\
\text { energy metabolism and other } \\
\text { hormone release [60], regulates } \\
\text { the production of other cytokines } \\
\text { and acute phase reactants }\end{array}$ & $\begin{array}{l}\text { mainly not from } \\
\text { adipocytes }\end{array}$ \\
\hline & & $\begin{array}{l}\text { IL-1 } \beta, \text { IL-8, } \\
\text { IL-10, IL-18, } \\
\text { IL-17D, } \\
\text { transforming } \\
\text { growth factor- } \beta \text {, } \\
\text { monocyte } \\
\text { chemoattractant } \\
\text { protein } 1\end{array}$ & $\begin{array}{l}\text { endocrine/ } \\
\text { paracrine }\end{array}$ & pro-inflammation? $[52,54]$ & $\begin{array}{l}\text { mainly not from } \\
\text { adipocytes }\end{array}$ \\
\hline & & $\begin{array}{l}\text { macrophage } \\
\text { migration } \\
\text { inhibiting factor }\end{array}$ & $\begin{array}{l}\text { endocrine/ } \\
\text { paracrine }\end{array}$ & macrophage infiltration [89] & $\begin{array}{l}\text { adipocytes and } \\
\text { other cell type }\end{array}$ \\
\hline & $\begin{array}{l}\text { acute phase } \\
\text { reactants }\end{array}$ & $\begin{array}{l}\text { haptoglobin, } \\
\text { serum amyloid } \\
\text { A3 }\end{array}$ & $\begin{array}{l}\text { endocrine/ } \\
\text { paracrine }\end{array}$ & protective? $[90,91]$ & $?$ \\
\hline & \multirow[t]{6}{*}{$\begin{array}{l}\text { vasculature } \\
\text { and neuron } \\
\text { related }\end{array}$} & $\begin{array}{l}\text { plasminogen } \\
\text { activator } \\
\text { inhibitor-1 }\end{array}$ & $\begin{array}{l}\text { paracrine/ } \\
\text { endocrine? }\end{array}$ & procoagulation [92] & adipocytes \\
\hline & & angiotensinogen & $\begin{array}{l}\text { autocrine/ } \\
\text { paracrine }\end{array}$ & $\begin{array}{l}\text { increase blood pressure? } \\
\text { stimulates adipogenesis through } \\
\text { prostacycline [93] }\end{array}$ & adipocytes \\
\hline & & adrenomedullin & $\begin{array}{l}\text { paracrine/ } \\
\text { autocrine/ } \\
\text { endocrine? }\end{array}$ & $\begin{array}{l}\text { decreases blood pressure, } \\
\text { decreases lipolysis [94] }\end{array}$ & $\begin{array}{l}\text { from both pre } \\
\text { and adipocytes }\end{array}$ \\
\hline & & $\begin{array}{l}\text { vascular } \\
\text { endothelial } \\
\text { growth factor }\end{array}$ & $\begin{array}{l}\text { paracinre/ } \\
\text { endocrine? }\end{array}$ & angiogenesis [95] & $\begin{array}{l}\text { mainly not from } \\
\text { adipocytes? }\end{array}$ \\
\hline & & apelin & $\begin{array}{l}\text { paracrine/ } \\
\text { endocrine? }\end{array}$ & $\begin{array}{l}\text { maintains body fluid homeostasis } \\
{[96,97]}\end{array}$ & $\begin{array}{l}\text { ubiquitous, } \\
\text { adipocytes and } \\
\text { neurons }\end{array}$ \\
\hline & & $\begin{array}{l}\text { nerve growth } \\
\text { factor }\end{array}$ & $\begin{array}{l}\text { paracrine/ } \\
\text { endocrine? }\end{array}$ & $\begin{array}{l}\text { development and survival of } \\
\text { sympathetic neurons [98] }\end{array}$ & $\begin{array}{l}\text { adipocytes and } \\
\text { stromal vascular } \\
\text { cells }\end{array}$ \\
\hline & \multirow[t]{5}{*}{$\begin{array}{l}\text { extracellular } \\
\text { matrix }\end{array}$} & collagens & $\begin{array}{l}\text { autocrine/ } \\
\text { paracrine }\end{array}$ & $\begin{array}{l}\text { involved in differentiation, and } \\
\text { may stimulate tumor growth [99] }\end{array}$ & $\begin{array}{l}\text { adipocytes, } \\
\text { endothelial cell }\end{array}$ \\
\hline & & $\begin{array}{l}\text { thrombos- } \\
\text { pondin-1 }\end{array}$ & $\begin{array}{l}\text { autocrine/ } \\
\text { paracrine }\end{array}$ & $\begin{array}{l}\text { cell-matrix and cell-cell } \\
\text { interactions }[100,101]\end{array}$ & $\begin{array}{l}\text { platelets, } \\
\text { adipocytes }\end{array}$ \\
\hline & & $\begin{array}{l}\text { metalloprotein- } \\
\text { ase inhibitors }\end{array}$ & $\begin{array}{l}\text { autocrine/ } \\
\text { paracrine }\end{array}$ & modulate differentiation [102] & adipocytes \\
\hline & & $\begin{array}{l}\text { matrix metallo- } \\
\text { proteinases }\end{array}$ & $\begin{array}{l}\text { autocrine/ } \\
\text { paracrine }\end{array}$ & modulate differentiation [102] & $\begin{array}{l}\text { adipocytes, } \\
\text { macrophages }\end{array}$ \\
\hline & & $\begin{array}{l}\text { secreted protein } \\
\text { acidic and rich in } \\
\text { cysteine }\end{array}$ & $\begin{array}{l}\text { autocrine/ } \\
\text { paracrine }\end{array}$ & $\begin{array}{l}\text { modulates cell adhesion, } \\
\text { differentiation and angiogenesis } \\
{[103]}\end{array}$ & adipocytes \\
\hline
\end{tabular}




\section{The secretory function of adipocytes in the etiology of obesity related disorders}

The physiological function of adipose tissue is essential to the body. When fat mass is lacking (lipoatrophy) in humans, complications similar to type 2 diabetes occur. In lipoatrophic mice models, ablation of WAT leads to severe consequences varying from death soon after birth to lipoatrophic (or lipodystrophic) diabetes with insulin resistance, dyslipidemia, hyperphagia and liver steatosis [104], while surgical implantation of adipose tissue reverses diabetes in lipoatrophic mice [105]. On the other side, in more frequent situations, overweight and obesity are a major risk for chronic diseases. The metabolic syndrome (also known as 'syndrome $\mathrm{X}$ ', or 'insulin resistance syndrome') [106] is a cluster of phenotypes that, both individually and collectively, contributes to an elevated risk of cardiovascular disorders. The features of the metabolic syndrome are insulin resistance, impaired glucose regulation, dyslipidaemia, hypertension, central obesity and microalbuminuria [107, 108], among which insulin resistance is the key component. Metabolic syndrome, insulin resistance, and ultimately type 2 diabetes caused by pancreatic $\beta$ cell failure, are strongly correlated with obesity. It is estimated that between $60 \%$ and $90 \%$ of cases of type 2 diabetes now appear to be related to obesity [109]. Together, the evidence shows that adipose tissue plays an important role in maintaining glucose and lipid homeostasis.

Adipocytes exert a protective action through their fat-storing capabilities, against the occurrence of lipotoxic damage to lean tissues, which is referred to as lipotoxicity (lipid-induced dysfunction) or as lipoapoptosis (lipid-induced programmed cell death) [110]. In addition, hormones secreted from adipocytes participate in regulating the energy balance. The alteration of the secretion profile of adipocytes and adipose tissues, under either a lipoatrophic or obese situation, play essential roles in the development of insulin resistance and metabolic syndrome. A number of adipocyte secreted factors as involved candidates are further explained:

- NEFAs

It is known for a long time that NEFAs secreted from adipocytes impair insulin action. According to the concept that substrates compete for respiration, the excess fatty acids will win the competition for respiration between substrates, via inhibition of the whole body glucose utilization and oxidation, predominantly in muscle, and inhibition of the insulin secretion response to glucose [111]. Furthermore, the endothelial dysfunction seen in obese subjects may also be a consequence of elevated NEFA levels, due to inhibitory effects on endothelial nitric oxide synthase [112].

\section{- Glucocorticoids}

Glucocorticoids, which levels vary with the size of fat mass, are thought to play a role in the regulation of energy stores [113]. They are able to regulate the feeding behavior and promote ingestion of "comfort foods" that may directly result in a reduction of the negative effects caused by chronic stress [114]. High glucocorticoids in the presence of insulin act directly on adipose tissue to stimulate intra-abdominal fat storage. These lipids serve, upon mobilization, as immediate substrates for liver. Glucocorticoids enhance gluconeogenesis and ketogenesis in liver, and inhibit the uptake of glucose in 
muscle [115]. In addition, cortisol stimulates the innate immune response [116]. From these various actions, excess of glucocorticoids may cause insulin resistance [117].

- Inflammation initiators

Insulin resistance is highly correlated to inflammation $(r=0.59, p<0.0001)$ [118]. It is generally assumed that adipocytes initiate the inflammation process and macrophages amplify the signals. Overload of lipid in adipocytes may initiate a state of cellular stress and activation of inflammatory signaling pathways, which leads to increased adipocyte production of pro-inflammatory cytokines, including tumor necrosis factor $\alpha$ (TNF $\alpha$ ), interleukin-6 (IL-6), and chemoattractant molecules such as monocyte chemoattractant protein 1 (MCP-1) and macrophage migration inhibiting factor (MIF). With the help from endothelial cells via interaction between adhesion molecules and integrins and chemokine receptors on the monocyte surface, monocytes are recruited to adipose tissues and differentiate into macrophages [119]. Another possible mechanism is that the macrophages are recruited to scavenge the adipocyte debris, in particular the residual lipid droplets, from dead adipocytes. The necrosis of adipocytes is approximately 3-times higher in obese than in lean human subjects, and also is increased with adipocyte hypertrophy [30]. Macrophages produce many of the same inflammatory cytokines and chemokines as those mentioned above, and additional ones, such as macrophage inflammatory proteins, to propagate inflammation both locally and systemically [119]. Cytokines, such as TNF $\alpha$ and IL-6, have pronounced catabolic effects, and can directly impair the anabolic signaling of insulin in cells [120, 121]. Portal delivery of adipose tissue derived cytokines and lipids may contribute to hepatic inflammation and insulin resistance. Pro-inflammatory cytokines produced in the adipose tissue and the liver create a systemic inflammatory status that promotes insulin resistance in skeletal muscle and other tissues [119].

\section{- Adiponectin}

This hormone is specifically and abundantly expressed in adipose tissue and directly sensitizes the body to insulin by stimulating AMP-activated protein kinase (AMPK) phosphorylation and activation. The adiponectin receptors have been found expressed on insulin target organs, adipocytes, liver and muscle. Its circulating level is reduced in obesity, limiting its insulin enhancing role in the obese state [80].

- Leptin

As an adipocyte-specific hormone, leptin is capable to alter food intake, body weight, energy expenditure and neuroendocrine function. The central metabolic functions of leptin lead to increased insulin sensitivity. The circulating level has a strong correlation with body fat, and the expression and secretion of leptin is increased in obesity. However, leptin resistance may occur in parallel [59].

\section{- Resistin}

It is secreted by adipocytes in mice, while in humans it is more expressed in macrophages and/or other cell types in adipose tissue than adipocytes. In mice it might have effect on the reduction of glucose tolerance and insulin action. However, in human its function is still unclear and its relevance to insulin resistance is in doubt [81]. 


\section{- Acylation-stimulating protein (ASP)}

This small protein, also named as C3adesArg, is produced by inter-hydrolysis processing of complement $\mathrm{C} 3$, factor $\mathrm{B}$ and adipsin. It appears to stimulate triglyceride uptake and lipogenesis in adipocytes. All the precursors and ASP have also been shown to be significantly increased in diabetes, but this is most likely a consequence of the relation between obesity and type 2 diabetes [122].

\section{- Visfatin}

It is a recently discovered adipokine that was shown to be associated with visceral fat in humans and rodents. Visfatin was also shown to mimic the effect of insulin with the same efficacy in rodent cells in vitro and in mouse models [83]. However, conflicting results were reported in humans with regard to its association with adiposity and insulin resistance. The plasma level has been reported as positively [123, 124], negatively [82], or not [125-127] correlated with adiposity/BMI. The strong correlation of its plasma level with visceral fat mass, rather than with subcutaneous fat mass [83], was not confirmed in other studies [124, 127, 128]. Furthermore, visfatin plasma levels were found to positively correlate to its mRNA level in visceral fat and negatively to that in subcutaneous fat in one study [124], but the other way around in another study [82]. Although the circulating visfatin level was found to be elevated in type 2 diabetes [126, 128], and changed up [125] or down [129] in women with gestational diabetes, most of the studies could not show a direct correlation between visfatin and insulin sensitivity/resistance indices. Furthermore a human model on fatty acid-induced skeletal muscle insulin resistance showed that visfatin did not play a role in the development of insulin resistance [82]. To enlighten the partially contradictory findings, the involvement of visfatin in lipid metabolism is investigated and discussed in Chapter 5 of this thesis.

The predominant cancers associated with obesity have a hormonal basis and include breast, prostate, endometrium, colon and gallbladder cancers. Obesity and other conditions related to chronic hyperinsulinemia result decreased levels of IGF-binding proteins, and higher levels of free plasma IGF-I. IGF-I stimulates cell proliferation and inhibits apoptosis and has been shown to have strong mitogenic effects in a wide variety of cancer cell lines [130]. Insulin and free IGF-I interact with and regulate the synthesis and bioavailability of sex steroid horomones that affect the development and progression of certain cancers. Chronic hyperinsulinemia inhibits hepatic synthesis of sex hormone-binding globulin, thus increasing the bioavailability of androgens and estrogens, which are essential for the growth, differentiation and function of many tissues. In addition to the effects on the bioavailability of sex hormones, adipose tissue itself secrets estrogens and contributes to circulating level in men and postmenopausal women. This estrogen may play an important role in the development of endometrial and breast cancers $[131,132]$. In addition, collagen type VI, abundantly secreted from adipocytes, is also suggested to stimulate breast tumor growth [99]. 


\section{Outline of the thesis}

Obesity and overweight pose a major risk for diet-related chronic diseases. Understanding the role of obesity is of major importance in the prevention and treatment of these related diseases. It has been shown that secretion products from adipocytes and adipose tissues play essential roles in the etiology of insulin resistance and metabolic syndrome, and some cancers. Some of these factors have been discovered, but apparently many more are still unknown. There is also still much to learn about how these signals function [43]. In this thesis, we sought to discover new secreted factors from adipocytes, which might possibly serve as a target for intervention to treat and/or prevent obesity and related diseases. We also attempted to understand the regulation of the secretion of these factors at the molecular level.

In this thesis an in vitro model system, murine 3T3-L1 cell line, is employed. It is one of the most frequently used preadipocyte cell lines to study adipogenesis and adipocytes. 3T3-L1 cells were clonally isolated from Swiss 3T3 disaggregated 17- to 19-day mouse embryos $[133,134]$. It has been committed solely to the adipocyte lineage, which means it is already in an early stage of adipocyte development. 3T3-L1 preadipocytes spontaneously differentiate over a period of several weeks into adipocytes when maintained in culture with fetal calf serum. This process can be accelerated by the adipogenesis inducing reagents dexamethasone and isobutylmethylxanthine. High concentration of insulin is used in combination with these inducing agents to accelerate lipid accumulation. Postaglandins $\mathrm{D}_{2}, 15$-deoxy- $\mathrm{J}_{2}$, and $\mathrm{I}_{2}$, as PPAR $\gamma$ ligands, also are used to stimulate adipogenesis [63]. In vitro differentiated adipocytes have many characteristics of adipocytes in vivo. Cells are able to accumulate a great deal of triglycerides and subcutaneous injection of 3T3-L1 adipocytes in nude mouse leads to development of mature fat pads that are histologically indistinguishable from white adipose tissue [135]. On a molecular basis, it has been shown that for many genes, differentiated 3T3-L1 cells accurately recapitulate the in vivo patterns of gene expression observed in the transition of preadipocytes to adipocytes. Many adipocytespecific and adipocyte-enriched genes, such as C/EBP $\alpha$, PPAR $\gamma 2$, SREBP-1a/1c, RXR, GLUT4, FABP4, FASN, adiponectin, and $\beta 3$-adrenergic receptor are highly expressed in 3T3-L1 adipocytes [136]. Compared to mature adipocytes in vivo, the phenotype of 3T3-L1 adipocytes shows some differences. The fat in 3T3-L1 adipocytes is present in multiple droplets [133], in contrast to a single big droplet in white adipocytes in vivo. However, the brown adipocytes marker UCP1 is not expressed in 3T3-L1 adipocytes, showing that 3T3-L1 adipocytes are white adipocytes. Leptin is expressed at a very low level in 3T3-L1 adipocytes and the close line 3T3-F442A [136, 137]. Taking all together, we decided to use 3T3-L1 cells, because they resemble the adipocytes in vivo to a large extent, offer a sustainable and stable study object that allows for comparison, and there is considerable information on gene expression.

To systematically screen new adipokines and understand the regulation events in adipocytes, we applied a proteomics approach using high-throughput two-dimensional gel electrophoresis and mass spectrometry [138]. Chapter 2 describes the work on the profiling of secreted proteins from 3T3-L1 adipocytes with this approach. We have identified some novel secreted proteins, especially growth factors, which may play roles 
in the function of adipocytes. In this chapter, we also indicated that extracellular matrix is an important component of adipocyte function and has a role in adipogenesis.

We have further investigated the regulation of the secretion of these proteins from 3T3L1 adipocytes, in relation to some important stimuli in the body, using a systems biology approach. Systems biology seeks to explain biological phenomena, not on a gene-by-gene basis, but through the net interactions of all cellular and biochemical components (DNA, RNA, protein, metabolites) within a cell or organism [139]. We focused on gene expression at mRNA level by transcriptomics [140] and gene production at protein level, especially at secreted protein level, by proteomics, and used bioinformatics tools. Chapter 3 and 4 describe the use of such a combined transcriptomics and proteomics approach. In Chapter 3, we reveal the important role of transcriptional regulation of protein processing for the effect of insulin on the adipocyte secretome. In Chapter 4 we describe how an anti-diabetic drug, rosiglitazone, exerts its effect on adipocytes through changing adipocytes metabolism and secretion, based on pathway analysis and supported by metabolite assessment.

To substantiate a functional role of the adipokines discovered in cell lines, additional studies are necessary in the whole organism. Here we used an epidemiological analysis, namely association study, to investigate the relation between the novel adipokines and obesity in humans. In Chapter 5, we assessed visfatin found by Fukuhara et al. in 2005 [83]. We conclude that in humans, circulating visfatin is not determined by lipid storage in adipose tissue. Rather, it is an indicator of a beneficial lipid profile. Further, we discuss our findings in relation to the enzymatic role of this protein in the metabolism of nicotinamide adenine dinucleotide (NAD), a substance that is able to increase HDLcholesterol considerably. In Chapter 6, we assessed a novel protein that we found to be secreted from 3T3-L1 adipocytes (Chapter 2), pigment epithelial-derived factor (PEDF) [141]. Interestingly, in humans, PEDF is associated with visceral fat in the body and is related to hypertension and type 2 diabetes.

Finally, the General Discussion presents the author's view on systems biology, the 3T3L1 adipocytes model and the role of the secretory function of adipocytes.

\section{References}

1. Organization, W.h., Information sheet on obesity and overweight. 2003, Geneva: World Health Organization.

2. World Health Organization, Obesity: preventing and managing the global epidemic. Report of a WHO Consultation, in WHO Technical Report Series, No. 894. 2000: Geneva.

3. Maes, H.H., M.C. Neale, and L.J. Eaves, Genetic and environmental factors in relative body weight and human adiposity. Behav Genet, 1997. 27(4): p. 325-51.

4. Fogelholm, M. and K. Kukkonen-Harjula, Does physical activity prevent weight gain--a systematic review. Obes Rev, 2000. 1(2): p. 95-111.

5. Wybranska, I. and M. Orho-Melander, Polymorphisms and Responsiveness to Diet. 2006, the European Nutrigenomics Organisation. p. E-learning module.

6. Pi-Sunyer, F.X., The obesity epidemic: pathophysiology and consequences of obesity. Obes Res, 2002. 10 Suppl 2: p. 97S-104S.

7. Manson, J.E., et al., Body weight and mortality among women. N Engl J Med, 1995. 333(11): p. 677-85.

8. Organization, W.H., Chapter 4: Quantifying selected major risks to health, in The World Health report 2002. 2002: Geneva. 
9. Shen, W., et al., Adipose tissue quantification by imaging methods: a proposed classification. Obes Res, 2003. 11(1): p. 5-16.

10. Hauner, H. and T. Skurk, Adipose Tissue Pathology in Human Obesity, in Adipose Tissue, S. Klaus, Editor. 2001, Landes Bioscience: Austin.

11. Cinti, S., The adipose organ. Prostaglandins Leukot Essent Fatty Acids, 2005. 73(1): p. 9-15.

12. Chakrabarty, K., B. Chaudhuri, and H. Jeffay, Glycerokinase activity in human brown adipose tissue. J Lipid Res, 1983. 24(4): p. 381-90.

13. Cunningham, S., et al., The characterization and energetic potential of brown adipose tissue in man. Clin Sci (Lond), 1985. 69(3): p. 343-8.

14. Cannon, B. and J. Nedergaard, Brown adipose tissue: function and physiological significance. Physiol Rev, 2004. 84(1): p. 277-359.

15. DiGirolamo, M., et al., Qualitative regional differences in adipose tissue growth and cellularity in male Wistar rats fed ad libitum. Am J Physiol, 1998. 274(5 Pt 2): p. R1460-7.

16. van der Kooy, K. and J.C. Seidell, Techniques for the measurement of visceral fat: a practical guide. Int J Obes Relat Metab Disord, 1993. 17(4): p. 187-96.

17. Giorgino, F., L. Laviola, and J.W. Eriksson, Regional differences of insulin action in adipose tissue: insights from in vivo and in vitro studies. Acta Physiol Scand, 2005. 183(1): p. 13-30.

18. Akazawa, S., et al., Efficacy of troglitazone on body fat distribution in type 2 diabetes. Diabetes Care, 2000. 23(8): p. 1067-71.

19. Flachs, P., et al., Polyunsaturated fatty acids of marine origin upregulate mitochondrial biogenesis and induce beta-oxidation in white fat. Diabetologia, 2005. 48(11): p. 2365-75.

20. Virtanen, K.A., et al., Glucose uptake and perfusion in subcutaneous and visceral adipose tissue during insulin stimulation in nonobese and obese humans. J Clin Endocrinol Metab, 2002. 87(8): p. 3902-10.

21. Klaus, S., Overview: biological significance of fat and adipose tissue, in Adipose Tissue, S. Klaus, Editor. 2001, Landes Bioscience: Georgetown,TX.

22. Garg, A., Regional adiposity and insulin resistance. J Clin Endocrinol Metab, 2004. 89(9): p. 4206-10.

23. Despres, J.P., Health consequences of visceral obesity. Ann Med, 2001. 33(8): p. 534-41.

24. Frayn, K.N., Visceral fat and insulin resistance--causative or correlative? Br J Nutr, 2000. 83 Suppl 1: p. S71-7.

25. Larson, D.R., et al., Water-soluble quantum dots for multiphoton fluorescence imaging in vivo. Science, 2003. 300(5624): p. 1434-6.

26. Fliers, E., et al., White adipose tissue: getting nervous. J Neuroendocrinol, 2003. 15(11): p. 1005-10.

27. Hauner, H., M. Wabitsch, and E.F. Pfeiffer, Differentiation of adipocyte precursor cells from obese and nonobese adult women and from different adipose tissue sites. Horm Metab Res Suppl, 1988. 19: p. 35-9.

28. Weisberg, S.P., et al., Obesity is associated with macrophage accumulation in adipose tissue. J Clin Invest, 2003. 112(12): p. 1796-808.

29. Curat, C.A., et al., From blood monocytes to adipose tissue-resident macrophages: induction of diapedesis by human mature adipocytes. Diabetes, 2004. 53(5): p. 1285-92.

30. Cinti, S., et al., Adipocyte death defines macrophage localization and function in adipose tissue of obese mice and humans. J Lipid Res, 2005. 46(11): p. 2347-55.

31. Rosen, E.D. and B.M. Spiegelman, Molecular regulation of adipogenesis. Annu Rev Cell Dev Biol, 2000. 16: p. 145-71.

32. Faust, I.M., et al., Diet-induced adipocyte number increase in adult rats: a new model of obesity. Am J Physiol, 1978. 235(3): p. E279-86.

33. Tholpady, S.S., et al., The cellular plasticity of human adipocytes. Ann Plast Surg, 2005. 54(6): p. 651-6.

34. Morroni, M., et al., Reversible transdifferentiation of secretory epithelial cells into adipocytes in the mammary gland. Proc Natl Acad Sci U S A, 2004. 101(48): p. 16801-6.

35. Hallakou, S., et al., Pioglitazone induces in vivo adipocyte differentiation in the obese Zucker fa/fa rat. Diabetes, 1997. 46(9): p. 1393-9.

36. Prins, J.B., et al., Tumor necrosis factor-alpha induces apoptosis of human adipose cells. Diabetes, 1997. 46(12): p. 1939-44.

37. Gregoire, F.M., Adipocyte differentiation: from fibroblast to endocrine cell. Exp Biol Med (Maywood), 2001. 226(11): p. 997-1002.

38. Ryden, M., et al., Functional characterization of human mesenchymal stem cell-derived adipocytes. Biochem Biophys Res Commun, 2003. 311(2): p. 391-7.

39. Miranville, A., et al., Improvement of postnatal neovascularization by human adipose tissue-derived stem cells. Circulation, 2004. 110(3): p. 349-55.

40. Sengenes, C., et al., Preadipocytes in the human subcutaneous adipose tissue display distinct features from the adult mesenchymal and hematopoietic stem cells. J Cell Physiol, 2005. 205(1): p. 114-22.

41. Trayhurn, P., C. Bing, and I.S. Wood, Adipose tissue and adipokines--energy regulation from the human perspective. J Nutr, 2006. 136(7 Suppl): p. 1935S-1939S. 
42. Cahill, G.F., Jr., Starvation in man. Clin Endocrinol Metab, 1976. 5(2): p. 397-415.

43. Lafontan, M., Fat cells: afferent and efferent messages define new approaches to treat obesity. Annu Rev Pharmacol Toxicol, 2005. 45: p. 119-46.

44. Shrago, E., T. Spennetta, and E. Gordon, Fatty acid synthesis in human adipose tissue. J Biol Chem, 1969. 244(10): p. 2761-6.

45. Hudgins, L.C., et al., Human fatty acid synthesis is stimulated by a eucaloric low fat, high carbohydrate diet. J Clin Invest, 1996. 97(9): p. 2081-91.

46. Aarsland, A., D. Chinkes, and R.R. Wolfe, Contributions of de novo synthesis of fatty acids to total VLDL-triglyceride secretion during prolonged hyperglycemia/hyperinsulinemia in normal man. J Clin Invest, 1996. 98(9): p. 2008-17.

47. Berg, J., et al., Biochmistry. 5th ed. 2002, New York: W. H. Freeman and Company.

48. Arner, P., Human fat cell lipolysis: biochemistry, regulation and clinical role. Best Pract Res Clin Endocrinol Metab, 2005. 19(4): p. 471-82.

49. Frayn, K.N., et al., Integrative physiology of human adipose tissue. Int J Obes Relat Metab Disord, 2003. 27(8): p. 875-88.

50. Zhang, Y., et al., Positional cloning of the mouse obese gene and its human homologue. Nature, 1994. 372(6505): p. 425-32.

51. Funahashi, T., et al., Role of adipocytokines on the pathogenesis of atherosclerosis in visceral obesity. Intern Med, 1999. 38(2): p. 202-6.

52. Trayhurn, P. and I.S. Wood, Adipokines: inflammation and the pleiotropic role of white adipose tissue. Br J Nutr, 2004. 92(3): p. 347-55.

53. $\mathrm{Xu}, \mathrm{H}$., et al., Chronic inflammation in fat plays a crucial role in the development of obesity-related insulin resistance. J Clin Invest, 2003. 112(12): p. 1821-30.

54. Fain, J.N., D.S. Tichansky, and A.K. Madan, Most of the interleukin 1 receptor antagonist, cathepsin S, macrophage migration inhibitory factor, nerve growth factor, and interleukin 18 release by explants of human adipose tissue is by the non-fat cells, not by the adipocytes. Metabolism, 2006. 55(8): p. 1113-21.

55. Fain, J.N., D.S. Tichansky, and A.K. Madan, Transforming growth factor beta1 release by human adipose tissue is enhanced in obesity. Metabolism, 2005. 54(11): p. 1546-51.

56. Fain, J.N., et al., Comparison of the release of adipokines by adipose tissue, adipose tissue matrix, and adipocytes from visceral and subcutaneous abdominal adipose tissues of obese humans. Endocrinology, 2004. 145(5): p. 2273-82.

57. Fain, J.N. and A.K. Madan, Regulation of monocyte chemoattractant protein 1 (MCP-1) release by explants of human visceral adipose tissue. Int J Obes (Lond), 2005. 29(11): p. 1299-307.

58. Fain, J.N., et al., Resistin release by human adipose tissue explants in primary culture. Biochem Biophys Res Commun, 2003. 300(3): p. 674-8.

59. Rajala, M.W. and P.E. Scherer, Minireview: The adipocyte--at the crossroads of energy homeostasis, inflammation, and atherosclerosis. Endocrinology, 2003. 144(9): p. 3765-73.

60. Mohamed-Ali, V., J.H. Pinkney, and S.W. Coppack, Adipose tissue as an endocrine and paracrine organ. Int J Obes Relat Metab Disord, 1998. 22(12): p. 1145-58.

61. Fruhbeck, G., et al., The adipocyte: a model for integration of endocrine and metabolic signaling in energy metabolism regulation. Am J Physiol Endocrinol Metab, 2001. 280(6): p. E827-47.

62. Gondret, F., P. Ferre, and I. Dugail, ADD-1/SREBP-1 is a major determinant of tissue differential lipogenic capacity in mammalian and avian species. J Lipid Res, 2001. 42(1): p. 106-13.

63. Gregoire, F.M., C.M. Smas, and H.S. Sul, Understanding adipocyte differentiation. Physiol Rev, 1998. 78(3): p. 783-809.

64. Wabitsch, M., et al., The role of growth hormone/insulin-like growth factors in adipocyte differentiation. Metabolism, 1995. 44(10 Suppl 4): p. 45-9.

65. Ben-Jonathan, N., et al., Focus on prolactin as a metabolic hormone. Trends Endocrinol Metab, 2006. 17(3): p. 110-6.

66. Forman, B.M., et al., 15-Deoxy-delta 12, 14-prostaglandin $\mathrm{J} 2$ is a ligand for the adipocyte determination factor PPAR gamma. Cell, 1995. 83(5): p. 803-12.

67. Olefsky, J.M., Treatment of insulin resistance with peroxisome proliferator-activated receptor gamma agonists. J Clin Invest, 2000. 106(4): p. 467-72.

68. Himms-Hagen, J., et al., Multilocular fat cells in WAT of CL-316243-treated rats derive directly from white adipocytes. Am J Physiol Cell Physiol, 2000. 279(3): p. C670-81.

69. Mayes, J.S. and G.H. Watson, Direct effects of sex steroid hormones on adipose tissues and obesity. Obes Rev, 2004. 5(4): p. 197-216.

70. Smart, J.L., V. Tolle, and M.J. Low, Glucocorticoids exacerbate obesity and insulin resistance in neuronspecific proopiomelanocortin-deficient mice. J Clin Invest, 2006. 116(2): p. 495-505.

71. Richelsen, B., Action of growth hormone in adipose tissue. Horm Res, 1997. 48 Suppl 5: p. 105-10. 
72. Couet, C., et al., Effect of dietary fish oil on body fat mass and basal fat oxidation in healthy adults. Int $\mathbf{J}$ Obes Relat Metab Disord, 1997. 21(8): p. 637-43.

73. Klaus, S., et al., Epigallocatechin gallate attenuates diet-induced obesity in mice by decreasing energy absorption and increasing fat oxidation. Int J Obes (Lond), 2005. 29(6): p. 615-23.

74. Marie Lagouge, et al., Resveratrol Improves Mitochondrial Function and Protects against Metabolic Disease by Activating SIRT1 and PGC-1a. Cell, 2006. in press.

75. Ailhaud, G., Adipose tissue as an endocrine organ. Int J Obes Relat Metab Disord, 2000. 24 Suppl 2: p. S1-3.

76. Faraj, M., H.L. Lu, and K. Cianflone, Diabetes, lipids, and adipocyte secretagogues. Biochem Cell Biol, 2004. 82(1): p. 170-90.

77. Wilkison, W.O., L. Choy, and B.M. Spiegelman, Biosynthetic regulation of monobutyrin, an adipocytesecreted lipid with angiogenic activity. J Biol Chem, 1991. 266(25): p. 16886-91.

78. Richelsen, B., Factors regulating the production of prostaglandin E2 and prostacyclin (prostaglandin I2) in rat and human adipocytes. Biochem J, 1987. 247(2): p. 389-94.

79. Jequier, E., Leptin signaling, adiposity, and energy balance. Ann N Y Acad Sci, 2002. 967: p. 379-88.

80. Kadowaki, T., et al., Adiponectin and adiponectin receptors in insulin resistance, diabetes, and the metabolic syndrome. J Clin Invest, 2006. 116(7): p. 1784-92.

81. Arner, P., Resistin: yet another adipokine tells us that men are not mice. Diabetologia, 2005. 48(11): p. 2203-5.

82. Pagano, C., et al., Reduced plasma visfatin/pre-B cell colony-enhancing factor in obesity is not related to insulin resistance in humans. J Clin Endocrinol Metab, 2006. 91(8): p. 3165-70.

83. Fukuhara, A., et al., Visfatin: a protein secreted by visceral fat that mimics the effects of insulin. Science, 2005. 307(5708): p. 426-30.

84. Semenkovich, C.F., et al., Insulin regulation of lipoprotein lipase activity in 3T3-L1 adipocytes is mediated at posttranscriptional and posttranslational levels. J Biol Chem, 1989. 264(15): p. 9030-8.

85. Fried, S.K., et al., Lipoprotein lipase regulation by insulin and glucocorticoid in subcutaneous and omental adipose tissues of obese women and men. J Clin Invest, 1993. 92(5): p. 2191-8.

86. Mandard, S., et al., The fasting-induced adipose factor/angiopoietin-like protein 4 is physically associated with lipoproteins and governs plasma lipid levels and adiposity. J Biol Chem, 2006. 281(2): p. 934-44.

87. Benoist, F., et al., Cholesteryl ester transfer protein mediates selective uptake of high density lipoprotein cholesteryl esters by human adipose tissue. J Biol Chem, 1997. 272(38): p. 23572-7.

88. Yang, Q., et al., Serum retinol binding protein 4 contributes to insulin resistance in obesity and type 2 diabetes. Nature, 2005. 436(7049): p. 356-62.

89. Skurk, T., et al., Production and release of macrophage migration inhibitory factor from human adipocytes. Endocrinology, 2005. 146(3): p. 1006-11.

90. Lin, Y., et al., Hyperglycemia-induced production of acute phase reactants in adipose tissue. J Biol Chem, 2001. 276(45): p. 42077-83.

91. Fain, J.N., S.W. Bahouth, and A.K. Madan, Haptoglobin release by human adipose tissue in primary culture. J Lipid Res, 2004. 45(3): p. 536-42.

92. Loskutoff, D.J. and F. Samad, The adipocyte and hemostatic balance in obesity: studies of PAI-1. Arterioscler Thromb Vasc Biol, 1998. 18(1): p. 1-6.

93. Ailhaud, G., M. Teboul, and F. Massiera, Angiotensinogen, adipocyte differentiation and fat mass enlargement. Curr Opin Clin Nutr Metab Care, 2002. 5(4): p. 385-9.

94. Linscheid, P., et al., Autocrine/paracrine role of inflammation-mediated calcitonin gene-related peptide and adrenomedullin expression in human adipose tissue. Endocrinology, 2005. 146(6): p. 2699-708.

95. Mick, G.J., X. Wang, and K. McCormick, White adipocyte vascular endothelial growth factor: regulation by insulin. Endocrinology, 2002. 143(3): p. 948-53.

96. Castan-Laurell, I., et al., Apelin, a novel adipokine over-produced in obesity: friend or foe? Mol Cell Endocrinol, 2005. 245(1-2): p. 7-9.

97. De Mota, N., et al., Apelin, a potent diuretic neuropeptide counteracting vasopressin actions through inhibition of vasopressin neuron activity and vasopressin release. Proc Natl Acad Sci U S A, 2004. 101(28): p. 10464-9.

98. Peeraully, M.R., J.R. Jenkins, and P. Trayhurn, NGF gene expression and secretion in white adipose tissue: regulation in 3T3-L1 adipocytes by hormones and inflammatory cytokines. Am J Physiol Endocrinol Metab, 2004. 287(2): p. E331-9.

99. Iyengar, P., et al., Adipocyte-derived collagen VI affects early mammary tumor progression in vivo, demonstrating a critical interaction in the tumor/stroma microenvironment. J Clin Invest, 2005. 115(5): p. 1163-76.

100.Voros, G. and H.R. Lijnen, Deficiency of thrombospondin-1 in mice does not affect adipose tissue development. J Thromb Haemost, 2006. 4(1): p. 277-8. 
101.Ramis, J.M., et al., Carboxypeptidase E and thrombospondin-1 are differently expressed in subcutaneous and visceral fat of obese subjects. Cell Mol Life Sci, 2002. 59(11): p. 1960-71.

102.Chavey, C., et al., Matrix metalloproteinases are differentially expressed in adipose tissue during obesity and modulate adipocyte differentiation. J Biol Chem, 2003. 278(14): p. 11888-96.

103. Takahashi, M., et al., The expression of SPARC in adipose tissue and its increased plasma concentration in patients with coronary artery disease. Obes Res, 2001. 9(7): p. 388-93.

104.Reitman, M.L., et al., Transgenic mice lacking white fat: models for understanding human lipoatrophic diabetes. Ann N Y Acad Sci, 1999. 892: p. 289-96.

105.Gavrilova, O., et al., Surgical implantation of adipose tissue reverses diabetes in lipoatrophic mice. J Clin Invest, 2000. 105(3): p. 271-8.

106.Sarafidis, P.A. and P.M. Nilsson, The metabolic syndrome: a glance at its history. J Hypertens, 2006. 24(4): p. 621-6.

107. Organization, W.H., Definition diagnosis and classification of diabetes mellitus and its complications. Report of a WHO Consultation. Part 1: Diagnosis and classification of diabetes mellitus. 1999, Geneva: World Health Organization.

108.Alberti, K.G. and P.Z. Zimmet, Definition, diagnosis and classification of diabetes mellitus and its complications. Part 1: diagnosis and classification of diabetes mellitus provisional report of a WHO consultation. Diabet Med, 1998. 15(7): p. 539-53.

109.Anderson, J.W., C.W. Kendall, and D.J. Jenkins, Importance of weight management in type 2 diabetes: review with meta-analysis of clinical studies. J Am Coll Nutr, 2003. 22(5): p. 331-9.

110.Unger, R.H., Lipid overload and overflow: metabolic trauma and the metabolic syndrome. Trends Endocrinol Metab, 2003. 14(9): p. 398-403.

111.Randle, P.J., Regulatory interactions between lipids and carbohydrates: the glucose fatty acid cycle after 35 years. Diabetes Metab Rev, 1998. 14(4): p. 263-83.

112.Davda, R.K., et al., Oleic acid inhibits endothelial nitric oxide synthase by a protein kinase C-independent mechanism. Hypertension, 1995. 26(5): p. 764-70.

113.Richard, D., Q. Huang, and E. Timofeeva, The corticotropin-releasing hormone system in the regulation of energy balance in obesity. Int J Obes Relat Metab Disord, 2000. 24 Suppl 2: p. S36-9.

114.Dallman, M.F., N.C. Pecoraro, and S.E. la Fleur, Chronic stress and comfort foods: self-medication and abdominal obesity. Brain Behav Immun, 2005. 19(4): p. 275-80.

115.Peters, A., et al., The selfish brain: competition for energy resources. Neurosci Biobehav Rev, 2004. 28(2): p. $143-80$.

116.Gabay, C. and I. Kushner, Acute-phase proteins and other systemic responses to inflammation. N Engl J Med, 1999. 340(6): p. 448-54.

117.Walker, B.R., Steroid metabolism in metabolic syndrome X. Best Pract Res Clin Endocrinol Metab, 2001. 15(1): p. 111-22.

118. Yudkin, J.S., Adipose tissue, insulin action and vascular disease: inflammatory signals. Int J Obes Relat Metab Disord, 2003. 27 Suppl 3: p. S25-8.

119.Shoelson, S.E., J. Lee, and A.B. Goldfine, Inflammation and insulin resistance. J Clin Invest, 2006. 116(7): p. 1793-801.

120.Shi, H., et al., Suppressor of cytokine signaling 3 is a physiological regulator of adipocyte insulin signaling. J Biol Chem, 2004. 279(33): p. 34733-40.

121.Argiles, J.M. and F.J. Lopez-Soriano, Catabolic proinflammatory cytokines. Curr Opin Clin Nutr Metab Care, 1998. 1(3): p. 245-51.

122. Cianflone, K., Z. Xia, and L.Y. Chen, Critical review of acylation-stimulating protein physiology in humans and rodents. Biochim Biophys Acta, 2003. 1609(2): p. 127-43.

123.Haider, D.G., et al., Increased plasma visfatin concentrations in morbidly obese subjects are reduced after gastric banding. J Clin Endocrinol Metab, 2006. 91(4): p. 1578-81.

124.Berndt, J., et al., Plasma visfatin concentrations and fat depot-specific mRNA expression in humans. Diabetes, 2005. 54(10): p. 2911-6.

125.Krzyzanowska, K., et al., Increased visfatin concentrations in women with gestational diabetes mellitus. Clin Sci (Lond), 2006. 110(5): p. 605-9.

126.Chen, M.P., et al., Elevated plasma level of visfatin/pre-B cell colony-enhancing factor in patients with type 2 diabetes mellitus. J Clin Endocrinol Metab, 2006. 91(1): p. 295-9.

127.Varma, V., et al., Human visfatin expression: relationship to insulin sensitivity, intramyocellular lipid and inflammation. J Clin Endocrinol Metab, 2006. in press.

128.Hammarstedt, A., et al., Visfatin is an adipokine but it is not regulated by thiazolidinediones. J Clin Endocrinol Metab, 2006. 91(3): p. 1181-4.

129.Chan, T.F., et al., Decreased plasma visfatin concentrations in women with gestational diabetes mellitus. J Soc Gynecol Investig, 2006. 13(5): p. 364-7. 
130.Tatar, M., A. Bartke, and A. Antebi, The endocrine regulation of aging by insulin-like signals. Science, 2003. 299(5611): p. 1346-51.

131.Calle, E.E. and M.J. Thun, Obesity and cancer. Oncogene, 2004. 23(38): p. 6365-78.

132.Bray, G.A., The underlying basis for obesity: relationship to cancer. J Nutr, 2002. 132 (11 Suppl): p. 3451S-3455S.

133.Green, H. and M. Meuth, An established pre-adipose cell line and its differentiation in culture. Cell, 1974. 3(2): p. 127-33.

134.Green, H. and O. Kehinde, Sublines of mouse 3 T3 cells that accumulate lipid. Cell, 1974. 1(3): p. $113-$ 116.

135.Green, H. and O. Kehinde, Formation of normally differentiated subcutaneous fat pads by an established preadipose cell line. J Cell Physiol, 1979. 101(1): p. 169-71.

136. Soukas, A., et al., Distinct transcriptional profiles of adipogenesis in vivo and in vitro. J Biol Chem, 2001. 276(36): p. 34167-74.

137.Mandrup, S., et al., Obese gene expression at in vivo levels by fat pads derived from s.c. implanted 3T3F442A preadipocytes. Proc Natl Acad Sci U S A, 1997. 94(9): p. 4300-5.

138.Pandey, A. and M. Mann, Proteomics to study genes and genomes. Nature, 2000. 405(6788): p. 837-46.

139.Liu, E.T., Systems Biology, Integrative Biology, Predictive Biology. Cell, 2005. 121(4): p. 505-506.

140.Lockhart, D.J. and E.A. Winzeler, Genomics, gene expression and DNA arrays. Nature, 2000. 405(6788): p. $827-36$.

141.Tombran-Tink, J., The neuroprotective and angiogenesis inhibitory serpin, PEDF: new insights into phylogeny, function, and signaling. Front Biosci, 2005. 10: p. 2131-49. 
Chapter 1. Introduction 


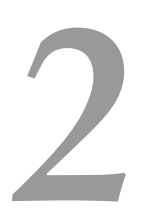

\section{Profiling of the secreted proteins during 3T3-L1 adipocyte differentiation leads to the identification of novel adipokines}

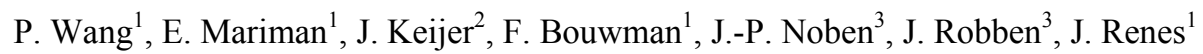

${ }^{1}$ Maastricht Proteomics Center, the Nutrition and Toxicology Research Institute Maastricht (NUTRIM), Department of Human Biology, Maastricht University, Maastricht, the Netherlands. ${ }^{2}$ RIKILT-Institute of Food Safety, Wageningen, the Netherlands. ${ }^{3}$ Biomedical Research Institute, Limburgs University Centrum and School of Life Sciences, Transnational University Limburg, Diepenbeek, Belgium.

CMLS, Cellular and Molecular Life Sciences. 61 (2004) 2405-2417

DOI $10.1007 / \mathrm{s} 00018-004-4256-\mathrm{z}$ 


\begin{abstract}
Adipose tissue is an endocrine organ capable of secreting a number of adipokines with a role in the regulation of adipose tissue and whole-body metabolism. We used twodimensional gel electrophoresis combined with mass spectrometry to profile the secreted proteins from (pre)adipocytes. The culture medium of 3T3-L1 cells during adipocyte differentiation was screened, and 41 proteins that responded to blocking of secretion by $20^{\circ} \mathrm{C}$ treatment and/or brefeldin A treatment were identified. Prohibitin, stress-70 protein, and adhesion-regulating molecule 1 are reported for the first time as secreted proteins. In addition, procollagen C-proteinase enhancer protein, galectin-1, cyclophilin A and C, and SF20/IL-25 are newly identified as adipocyte secreted factors. Secretion profiles indicated a dynamic environment including an actively remodeling extracellular matrix and several factors involved in growth regulation.
\end{abstract}

\title{
Key words
}

3T3-L1 adipocyte, secretion, proteomics, extracellular matrix, growth regulation. 


\section{Introduction}

Obesity is one of the most frequent nutritional disorders in western societies. It is strongly associated with type II diabetes, cardiovascular diseases and cancer [1, 2]. Obesity is characterized by excess of body fat mass, which is mostly stored in adipose tissue. In addition, adipose tissue is an endocrine organ able to secrete a number of signal molecules. Adipocyte-specific or -enriched secreted proteins, termed adipokines, have a variety of local, peripheral and central effects on metabolism, which could be links between obesity and related diseases [3, 4]. Novel secreted proteins involved in lipid and glucose metabolism have been discovered in the last 10 years, such as leptin, adiponectin, and resistin, but also proteins with alternative functions such as complement $\mathrm{C}$ and D (adipsin), which are also involved in triglyceride synthesis [4]. Until now, the number of systematic searches for secreted proteins from preadipocytes, adipocytes and/or adipose tissue is limited. Genes that encode adipocyte-specific or enriched secreted or surface proteins have been screened in 3T3-L1 adipocytes and human visceral adipose tissue [5-7]. At the protein level, one-dimensional (1D)electrophoresis and liquid chromatography-based separation combined with tandem mass spectrometry (MS/MS) have been used to identify secreted proteins during differentiation of 3T3-L1 preadipocytes to adipocytes [8].

Here we present our results for proteins secreted during adipocyte differentiation using a systematic proteomic approach, based on the selective blocking of secretion pathways. Proteins can be secreted via the endoplasmic reticulum (ER)/Golgi-dependent pathway to the extracellular space. In addition, some proteins are found to be secreted via ER/Golgi-independent pathways [9]. Brefeldin A (BFA) is known to inhibit protein secretion in eukaryotic cells by interfering with the function of the Golgi apparatus [10]. Treatment at $20^{\circ} \mathrm{C}$ blocks both the ER/Golgi pathway as well as the ER/Golgiindependent pathways [11]. Both BFA and $20^{\circ} \mathrm{C}$ treatment have been reported to totally block the secretion of leptin from 3T3-L1 adipocytes [12]. We employed mouse 3T3-L1 cells, as the model system most frequently used to study adipocytes in vitro [13]. We used $20^{\circ} \mathrm{C}$ or BFA treatment to block protein secretion, allowing us to discriminate the secreted proteins from non-secreted, leaked proteins in the medium. We screened the culture medium by two-dimensional (2D) gel electrophoresis followed by MS for identification. This approach led to the discovery of novel adipokines.

\section{Materials and methods}

Chemicals were purchased from Sigma (Zwijndrecht, The Netherlands) unless stated otherwise.

Cell culture and medium protein sample preparation Murine 3T3-L1 fibroblasts (American Type Culture Collection) were cultured and differentiated in vitro essentially as described by Bouwman et al. [14], except that preadipocytes were treated with an adipogenic cocktail for 2 days. Differentiation was monitored by the visual appearance of fat droplets in the cells. On day $0,4,8$ and 12 of differentiation, 3T3-L1 cells cultured in 150-mm dishes were prepared for sampling by washing the cells three times with $25 \mathrm{ml}$ serum-free medium (D-MEM/F-12, 1:1; Invitrogen, Breda, The 
Netherlands). Then, the washed cells were incubated in $12 \mathrm{ml}$ phenol red-free and serum-free medium supplemented with $0.7 \mu \mathrm{M}$ bovine insulin, $2.2 \mathrm{mg} / \mathrm{l}$ human transferrin, $10.6 \mathrm{nM}$ sodium selenium and $13.1 \mu \mathrm{M}$ ethanolamine at $37^{\circ} \mathrm{C}$ or $20^{\circ} \mathrm{C}$. To block the secretion of cells with BFA, a pretreatment of adding $20 \mu \mathrm{M}$ BFA to the medium for $1 \mathrm{~h}$ at $37^{\circ} \mathrm{C}$ was performed before washing. After washing, the cells were incubated in the medium supplemented with $20 \mu \mathrm{M}$ BFA at $37^{\circ} \mathrm{C}$. After $8 \mathrm{~h}$, the media were harvested, and centrifuged at $4^{\circ} \mathrm{C}, 150 \mathrm{~g}$ for $10 \mathrm{~min}$. The supernatants were transferred to dialysis tubes (2-kDa molecular-weight cutoff; Spectrum Laboratories, Rancho Dominguez, Calif. US) and dialyzed against $20 \mathrm{mM} \mathrm{NH} 4 \mathrm{HCO} 3$ at $4^{\circ} \mathrm{C}$ for $20 \mathrm{~h}$. Meanwhile, the cells were trypsinized and counted with a hemocytometer. The dialyzed medium samples were freeze-dried and dissolved in fresh rehydration buffer ( $8 \mathrm{M}$ urea, 2\% w/v CHAPS, $65 \mathrm{mM}$ dithiothreitol, 0.5\% v/v IPG buffer 3-10 NL (Amersham Bioscience, Roosendaal, The Netherlands)). The protein concentrations of the samples were measured by a protein assay kit (Bio-Rad, Veenendaal, The Netherlands), based on the method of Bradford. Aliquots were stored at $-80^{\circ} \mathrm{C}$. Independent triplicate experiments were performed.

Two-dimensional gel electrophoresis Medium samples derived from $2.2 \times 10^{6}$ cells were used for 2D gel analysis according to Bouwman et al. [14] but with 24-cm pH 310 NL strips. The gels were silver stained simultaneously [15]. The images of gels were obtained using a GS-800 calibrated densitometer (Bio-Rad), and processed by PDQuest 7.2 (Bio-Rad). The gel intensity was normalized with respect to the total protein amount applied on the gel. Gels from the samples with the same time point and the same treatment in three independent experiments formed one replicate group with average spot intensities (absent spots were excluded). A difference of the average value of the spot intensity between groups was considered as meaningful at a threshold ratio of 2 or more. Any spot that showed a difference between the $37^{\circ} \mathrm{C}$ condition and the blocking condition, $20^{\circ} \mathrm{C}$ or BFA treatment, was selected for further identification. To simplify MS-dependent identification of spots, parallel gels were made with higher sample loading, and stained with Coomassie Brilliant Blue. The differentially expressed spots were excised using an automated spot cutter (Bio-Rad).

MS and protein identification Spots were in-gel digested and peptide-mass fingerprints were obtained by matrix-assisted laser desorption/ionization- time of flight mass spectrometry (MALDI-TOF) (Waters, Almere, The Netherlands) as described by Bouwman et al. [14]. Some spots that could not be identified by MALDI-TOF analysis were further processed by liquid chromatography electrospray ionization tandem mass spectrometry (LC-MS/MS) as described by Dumont et al. [16], allowing a maximum of one missed cleavage. The MALDI-TOF data were screened against the Swiss-Prot database using the ProteinLynx GlobalServer (Waters), and against the National Center for Biotechnology Information non-redundant mouse database using Mascot (http://www.matrixscience.com/search_form_select.html) and Profound (http://prowl. rockefeller.edu/profound_bin/WebProFound.exe). The MS/MS data were screened against the GenBank non-redundant mouse database using Mascot and Sequest (ThermoFinnigan, San Jose, Calif.). 
1D and 2D Western blotting To confirm the identity of adiponectin, adipocyte medium samples were analyzed by $1 \mathrm{D}$ or 2D Western blot. For preparing the 1D blot, proteins were separated on a denaturing $12.5 \%$ gel. For the $2 \mathrm{D}$ blot, samples were separated on immobilized 11-cm (Bio-Rad) $\mathrm{pH}$ 3-10 non-linear strips followed by second-dimensional separation on $12.5 \%$ Criterion gels (Bio-Rad), according to the manufacturer's instruction. The separated proteins were transferred to Hybond ECL nitrocellulose membrane (Amersham Bioscience). An additional 2D gel was run in parallel followed by silver staining for reference. After blocking, the blots were probed with an anti-mouse adiponectin monoclonal antibody (Chemicon, Chandlers Ford, UK), washed, and incubated with a horseradish peroxidase-conjugated secondary antibody (DAKO, Glostrup, Denmark). The signals were detected by Super- Signal West Pico Chemiluminescent reagent and CLXPose clear blue X-ray film (Perbio Science, Ettenleur, The Netherlands).

Amino acid sequence search for features of secreted proteins For the identified secreted protein candidates without a signal peptide as indicated by Swiss-Prot, the amino acid sequence was analyzed [17] with SignalP V2.0.b2 and TMAP. SignalP [18] predicts the presence and location of signal peptide cleavage sites in the N-terminal part (first 70 residues). TMAP [19] predicts the number of transmembrane domains.

\section{Results}

Identification of secreted proteins from 3T3-L1 cells during adipocyte differentiation On day 12 of differentiation, more than half of the cells showed adipogenic conversion characterized by visible fat droplets inside the cells. The secreted proteins in cell culture medium were harvested at day $0,4,8$, and 12 , and profiled using 2D gel electrophoresis (fig. 1A). From a total of 1077 spots, 193 responded to blocking conditions; 158 spots were blocked by $20^{\circ} \mathrm{C}$ as well as by BFA treatment, 32 spots were blocked only by the $20^{\circ} \mathrm{C}$ treatment. One of these spots, which was later identified as SF20/IL-25, was blocked at day 4 and 8, but not at day 12. Another three spots were only blocked by the BFA treatment. In total, from 161 spots, the proteins could be identified by MALDI-TOF MS and LC-MS/MS, and are marked on the master gel (fig. $1 \mathrm{~B}$ ). These spots represent 41 different proteins (table 1). 


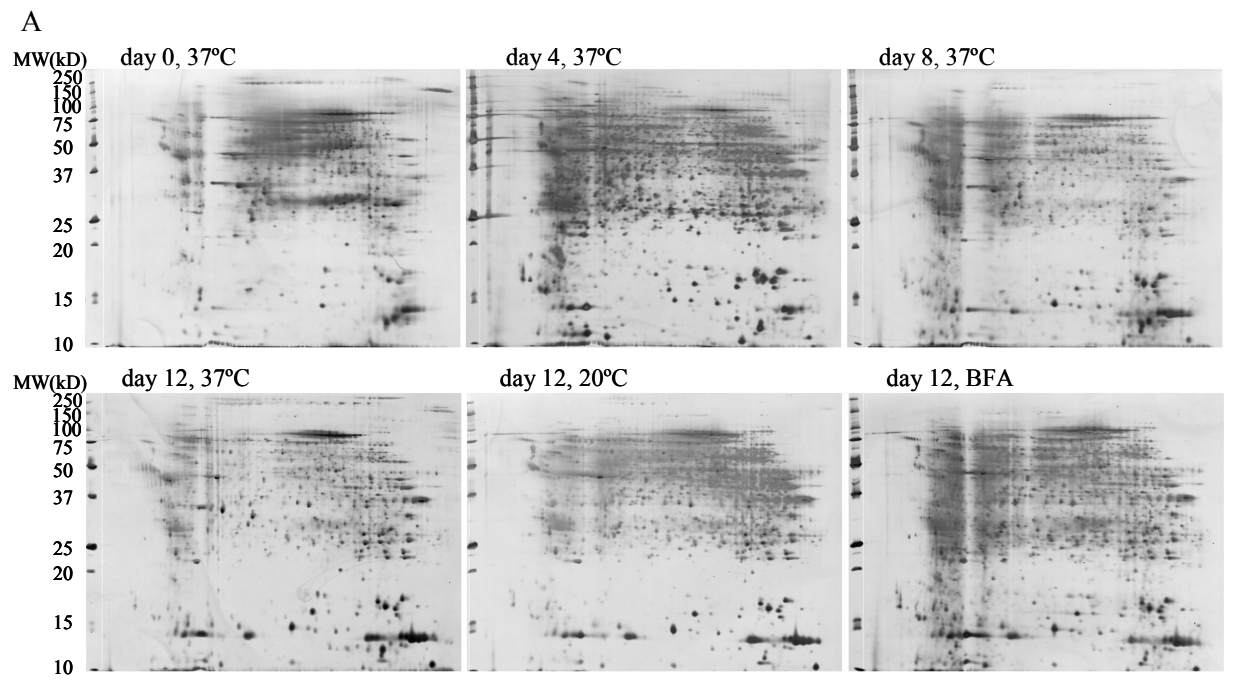

B

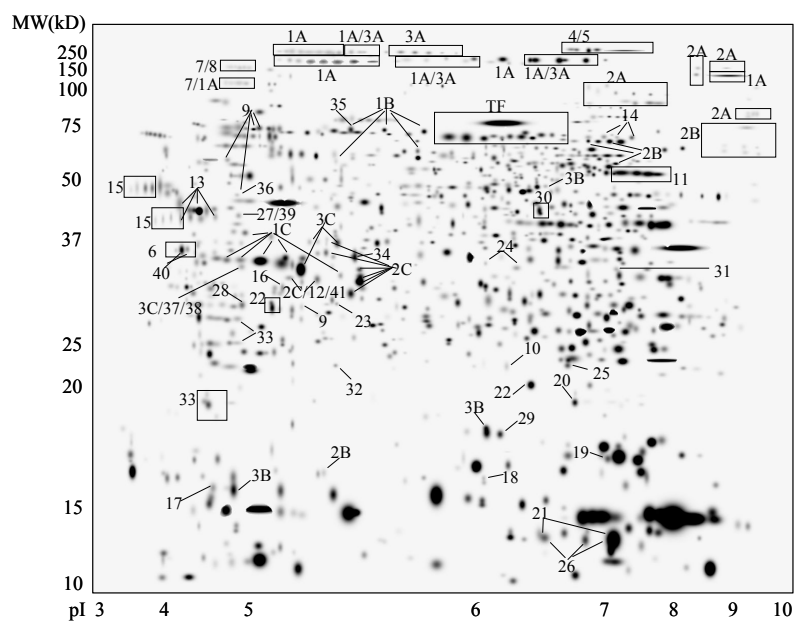

Fig. 1. Medium proteins from 3T3-L1 cells during differentiation separated on 2D gels. (A) Representative gels of medium proteins, derived from $2.2 \times 10^{6} 3 \mathrm{~T} 3$-L1 cells on day $0,4,8$, and 12 , and on day 12 treated with $20^{\circ} \mathrm{C}$ or $20 \mu \mathrm{M}$ BFA. (B) The master gel with identified (mixed) spots. Spot numbers refer to the ID of the protein in table 1 (TF, human transferrin). 
Table 1. Identification of candidate secreted proteins from 3T3-L1 cells during differentiation.

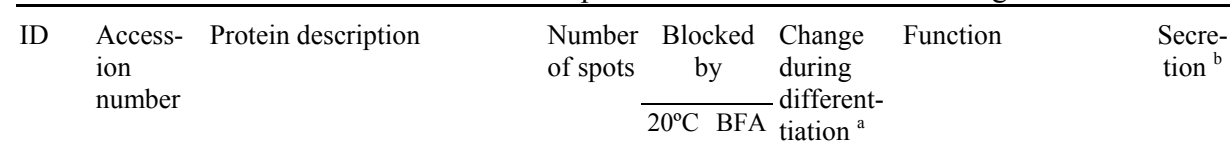

\begin{tabular}{|c|c|c|c|c|c|c|c|c|}
\hline \multicolumn{9}{|c|}{ Extracellular matrix and related proteins } \\
\hline $1 \mathrm{~A}$ & P11087 & (pro) collagen type I alpha 1 & 35 & yes & yes &,$\pm \mathrm{v}$ & $\begin{array}{l}\text { extracellular matrix } \\
\text { component }\end{array}$ & I \\
\hline 1B & & $\begin{array}{l}\text { collagen type I alpha } 1 \\
\text { fragment }\end{array}$ & 5 & yes $^{c}$ & yes & + & & I \\
\hline $1 \mathrm{C}$ & & $\begin{array}{l}\text { collagen type I alpha } 1 \mathrm{C} \text { - } \\
\text { terminal propeptide }\end{array}$ & 6 & yes $^{c}$ & yes $^{d}$ &,$\pm \mathrm{v}$ & $\begin{array}{l}\text { collagen catabolism } \\
\text { by-product }\end{array}$ & I \\
\hline $2 \mathrm{~A}$ & Q01149 & (pro) collagen type I alpha 2 & 15 & yes & yes &,$\pm \mathrm{v}$ & $\begin{array}{l}\text { extracellular matrix } \\
\text { component }\end{array}$ & I \\
\hline $2 \mathrm{~B}$ & & $\begin{array}{l}\text { collagen type I alpha } 2 \\
\text { fragment }\end{array}$ & 10 & yes & yes $^{d}$ & + & & I \\
\hline $2 \mathrm{C}$ & & $\begin{array}{l}\text { collagen type I alpha } 2 \mathrm{C} \text { - } \\
\text { terminal propeptide }\end{array}$ & 8 & yes & yes &,$\pm \mathrm{v}$ & $\begin{array}{l}\text { collagen catabolism } \\
\text { by-product }\end{array}$ & I \\
\hline $3 \mathrm{~A}$ & P08121 & (pro) collagen type III alpha 1 & 19 & yes & yes &,$\pm \mathrm{v}$ & $\begin{array}{l}\text { extracellular matrix } \\
\text { component }\end{array}$ & I \\
\hline 3B & & $\begin{array}{l}\text { collagen type III alpha } 1 \\
\text { fragment }\end{array}$ & 3 & yes & yes & + & & I \\
\hline $3 \mathrm{C}$ & & $\begin{array}{l}\text { collagen type III alpha } 1 \mathrm{C} \text { - } \\
\text { terminal propeptide }\end{array}$ & 4 & yes & yes &,$\pm \mathrm{v}$ & $\begin{array}{l}\text { collagen catabolism } \\
\text { by-product }\end{array}$ & I \\
\hline 4 & P02463 & (pro) collagen type IV alpha 1 & 5 & yes & yes & + & $\begin{array}{l}\text { extracellular matrix } \\
\text { component }\end{array}$ & I \\
\hline 5 & P08122 & (pro) collagen type IV alpha 2 & 5 & yes & yes & + & $\begin{array}{l}\text { extracellular matrix } \\
\text { component }\end{array}$ & I \\
\hline 6 & O88207 & $\begin{array}{l}\text { collagen type } \mathrm{V} \text { alpha } 1 \\
\text { fragment }\end{array}$ & 3 & yes & yes & + & $\begin{array}{l}\text { extracellular matrix } \\
\text { component }\end{array}$ & I \\
\hline 7 & Q04857 & (pro) collagen type VI alpha 1 & 8 & yes & yes &,$+ \wedge$ & $\begin{array}{l}\text { extracellular matrix } \\
\text { component }\end{array}$ & I \\
\hline 8 & Q02788 & (pro) collagen type VI alpha 2 & 1 & yes & yes &,$+ \wedge$ & $\begin{array}{l}\text { extracellular matrix } \\
\text { component }\end{array}$ & I \\
\hline 9 & P33434 & $\begin{array}{l}\text { matrix metalloproteinase- } 2 \text { and } \\
\text { fragment }\end{array}$ & 6 & yes & yes & \pm & collagen catabolism & I \\
\hline 10 & P25785 & metalloproteinase inhibitor 2 & 1 & yes & yes & + & $\begin{array}{l}\text { inhibitor of } \\
\text { metalloproteinases }\end{array}$ & I \\
\hline 11 & Q61398 & $\begin{array}{l}\text { procollagen C-proteinase } \\
\text { enhancer protein }\end{array}$ & 6 & yes & yes & \pm & collagen catabolism & I \\
\hline 12 & P28301 & protein-lysine 6-oxidase & 2 & yes & yes &,$\pm \mathrm{v}(\mathrm{m})$ & $\begin{array}{l}\text { modification for } \\
\text { fibrous collagen }\end{array}$ & I \\
\hline 13 & P07214 & SPARC, osteonectin & 4 & yes & yes & ++ & $\begin{array}{l}\text { modulator of cell- } \\
\text { matrix interaction }\end{array}$ & I \\
\hline \multicolumn{9}{|c|}{ Lipid metabolism } \\
\hline 14 & P01027 & complement $\mathrm{C} 3$ beta chain & 3 & yes & yes & ++ & $\begin{array}{l}\text { stimulate triglyceride } \\
\text { synthesis }\end{array}$ & I \\
\hline 15 & P03953 & adipsin & 8 & yes & yes & ++ & $\begin{array}{l}\text { stimulate triglyceride } \\
\text { synthesis }\end{array}$ & I \\
\hline 16 & Q60994 & adiponectin & 1 & no & yes & ++ & $\begin{array}{l}\text { control of fat } \\
\text { metabolism and } \\
\text { insulin sensitivity }\end{array}$ & I \\
\hline
\end{tabular}


Table 1. Identification of candidate secreted proteins from 3T3-L1 cells during differentiation (continued).

\begin{tabular}{|c|c|c|c|c|c|c|c|c|}
\hline \multicolumn{9}{|c|}{ Growth regulation } \\
\hline 17 & $\mathrm{P} 16045$ & galectin-1 & 1 & yes & no & ++ & growth regulator & I \\
\hline 18 & Q9CPT4 & $\begin{array}{l}\text { Stromal cell-derived growth } \\
\text { factor SF20/IL-25 }\end{array}$ & 1 & no & no & ++ & $\begin{array}{l}\text { stimulate limphcyte } \\
\text { proliferation }\end{array}$ & I \\
\hline 19 & P17742 & cyclophilin A & 1 & yes & no &,$+ \wedge$ & $\begin{array}{l}\text { protein folding, } \\
\text { immune regulation }\end{array}$ & I \\
\hline 20 & P30412 & cyclophilin C & 1 & yes & no & + & $\begin{array}{l}\text { protein folding, } \\
\text { immune regulation }\end{array}$ & I \\
\hline 21 & P34884 & $\begin{array}{l}\text { macrophage migration } \\
\text { inhibitory factor }\end{array}$ & 2 & yes & yes & $\pm(\mathrm{m})$ & $\begin{array}{l}\text { pro-inflammatory } \\
\text { cytokines }\end{array}$ & I \\
\hline 22 & P97298 & $\begin{array}{l}\text { pigment epithelium-derived } \\
\text { factor (fragment) }\end{array}$ & 3 & yes & yes &,$\pm \mathrm{v}$ & neurotrophic protein & I \\
\hline 23 & P24142 & prohibitin & 1 & yes & no & - & $\begin{array}{l}\text { inhibits DNA } \\
\text { synthesis }\end{array}$ & II \\
\hline \multicolumn{9}{|c|}{ Others } \\
\hline 24 & O09164 & extracellular SOD & 2 & yes & yes & ++ & antioxidant & I \\
\hline 25 & P35700 & peroxiredoxin 1 & 1 & yes & no & ++ & antioxidant & II \\
\hline 26 & P01887 & beta-2 microglobulin & 3 & yes & yes & $\pm(\mathrm{m})$ & cell defense & I \\
\hline 27 & Q61646 & haptoglobin & 1 & yes & no & $++(\mathrm{m})$ & $\begin{array}{l}\text { acute-phase response, } \\
\text { proteolysis }\end{array}$ & I \\
\hline 28 & P02571 & gamma-actin fragment & 1 & yes & yes & + & cytoskeleton & II \\
\hline 29 & P18760 & cofilin, non-muscle isoform & 1 & yes & no & ++ & $\begin{array}{l}\text { control of actin } \\
\text { polymerization }\end{array}$ & II \\
\hline 30 & P13020 & gelsolin fragment & 2 & yes & yes &,$+ \wedge$ & $\begin{array}{l}\text { actin-depolymerizing } \\
\text { factor }\end{array}$ & I \\
\hline 31 & O88569 & $\begin{array}{l}\text { heterogeneous nuclear } \\
\text { ribonucleoprotein A2/B1 }\end{array}$ & 1 & yes & yes &,$++ \wedge$ & pre-mRNA processing & II \\
\hline
\end{tabular}

\begin{tabular}{|c|c|c|c|c|c|c|c|c|}
\hline \multicolumn{9}{|c|}{ High expression on day 4 and only blocked by $20^{\circ} \mathrm{C}$ treatment } \\
\hline 32 & Q9DCX2 & $\begin{array}{l}\text { ATP synthase D chain, } \\
\text { mitochondrial }\end{array}$ & 1 & yes & no &,$\pm^{\wedge}$ & proton transport & II \\
\hline 33 & P20152 & vimentin fragment & 5 & yes & no &,$\pm \wedge$ & intermediate filament & II \\
\hline 34 & $\mathrm{P} 02570$ & beta-actin fragment & 1 & yes & no &,$++ \wedge$ & cytoskeleton & II \\
\hline \multicolumn{9}{|c|}{ From mixed spots } \\
\hline 35 & P38647 & $\begin{array}{l}\text { stress- } 70 \text { protein, } \\
\text { mitochondrial }\end{array}$ & 1 & no & yes & $++(\mathrm{m})$ & chaperone & II \\
\hline 36 & Q9JKV1 & adhesion regulating molecule 1 & 1 & yes & yes & $-(\mathrm{m})$ & cell adhesion & II \\
\hline 37 & P48036 & annexin A5 & 1 & yes & yes & $\pm(\mathrm{m})$ & phospholipid binding & II \\
\hline 38 & Q9JM65 & $\begin{array}{l}\text { nonclathrin coat protein } \\
\text { epsilon-COP }\end{array}$ & 1 & yes & yes & $\pm(\mathrm{m})$ & protein transport & II \\
\hline 39 & Q01853 & $\begin{array}{l}\text { transitional endoplasmic } \\
\text { reticulum ATPase fragment }\end{array}$ & 1 & yes & no & $++(\mathrm{m})$ & protein transport & II \\
\hline 40 & Q60817 & $\begin{array}{l}\text { NASCENT polypeptide- } \\
\text { associated complex alpha } \\
\text { polypeptide }\end{array}$ & 2 & yes & yes & $+(\mathrm{m})$ & $\begin{array}{l}\text { protein transport, } \\
\text { transcription } \\
\text { coactivator }\end{array}$ & II \\
\hline 41 & P17182 & alpha enolase fragment & 2 & yes & yes &,$\pm \mathrm{v}(\mathrm{m})$ & glycolysis & Il \\
\hline
\end{tabular}


Secretion features of candidate proteins Of the 41 candidate proteins, 26 were reported in the literature as secreted proteins. With the exception of cyclophilin A, these proteins are located in the extracellular space as annotated in the Swiss-Prot or the SOURCE (http://source.stanford.edu) database. However, 5 of these known extracellular proteins are without a secretion signal peptide as annotated in the database: collagen $\mathrm{V}$ alpha 1, galectin-1, macrophage migration inhibitory factor (MIF), stromal cell-derived growth factor SF20/IL-25, and cyclophilin C. To screen for the potential secretion features, these 5 proteins and cyclophilin A were analyzed together with the remaining 15 proteins by the SignalP and TMAP programs. In three proteins, collagen $\mathrm{V}$ alpha 1, SF20/IL-25, and cyclophilin C, a secretion signal peptide sequence could be identified. Furthermore, prohibitin, stress-70 protein, and adhesion-regulating molecule 1 were found to harbor a predicted secretion signal sequence indicating that these are genuine secreted proteins. Peroxiredoxin 1 might be anchored to the membrane because it has a predicted N-terminal transmembrane helix. Transitional endoplasmic reticulum ATPase and alpha enolase have a predicted transmembrane helix in the middle of the sequence, which is a feature of a transmembrane protein. The remaining 12 proteins, including the known secreted proteins galectin-1 and MIF, lack both the secretion signal sequence and the membrane anchor sequences (table 2).

Table 2. Predicted secretion features of the candidate secreted proteins from 3T3-L1 cells during differentiation.

\begin{tabular}{|c|c|c|c|c|}
\hline ID & Protein & $\begin{array}{l}\text { Annotated } \\
\text { location }^{\text {a }}\end{array}$ & $\begin{array}{l}\text { Nmber of } \\
\text { transmembrane- } \\
\text { helix }^{b}\end{array}$ & $\begin{array}{l}\text { Presence of } \\
\text { signal } \\
\text { peptide }^{c}\end{array}$ \\
\hline$\overline{6}$ & collagen type $\mathrm{V}$ alpha 1 & Exs & 1 & yes \\
\hline 18 & SF20/IL-25 & Exs & 1 & yes \\
\hline 20 & cyclophilin C & Cyt, Exs & 1 & yes \\
\hline 17 & galectin-1 & Exs & 0 & no \\
\hline 21 & macrophage migration inhibitory factor & Exs & 0 & no \\
\hline 19 & cyclophilin A & Cyt & 0 & no \\
\hline 36 & adhesion regulating molecule 1 & Mem & 0 & yes \\
\hline 23 & prohibitin & Cyt & $1(\mathrm{~N}-)$ & yes \\
\hline 35 & stress-70 protein, mitochondrial & Mit & $1(\mathrm{~N}-)$ & yes \\
\hline 25 & peroxiredoxin 1 & Cyt & $1(\mathrm{~N}-)$ & no \\
\hline 39 & transitional endoplasmic reticulum ATPase (fragment) & Gol, ER, Nuc & 1 (middle) & no \\
\hline 41 & alpha enolase (fragment) & Cyt & 1 (middle) & no \\
\hline 28 & gamma-actin (fragment) & Cyt & 0 & no \\
\hline 29 & cofilin, non-muscle isoform & Nuc, Cyt & 0 & no \\
\hline 31 & heterogeneous nuclear ribonucleoprotein A2/B1 & Nuc & 0 & no \\
\hline 32 & ATP synthase D chain, mitochondrial & Mit & 0 & no \\
\hline 33 & vimentin (fragment) & Cyt & 0 & no \\
\hline 34 & beta-actin (fragment) & Cyt & 0 & no \\
\hline 37 & annexin A5 & Mem & 0 & no \\
\hline 38 & nonclathrin coat protein epsilon-COP & Mem, Gol & 0 & no \\
\hline 40 & $\begin{array}{l}\text { NASCENT polypeptide-associated complex alpha } \\
\text { polypeptide }\end{array}$ & Nuc, Cyt & 0 & no \\
\hline
\end{tabular}

a From Swiss-Prot database. Exs, extracelluar space; Cyt, cytoplasm; Mem, membrane; Gol, Golgi apparatus; ER, endoplasmic reticulum; Mit, mitochondrion; Nuc, nucleus. ${ }^{\mathrm{b}}$ Predicted by TMAP program; N, N-terminal. ${ }^{\mathrm{c}}$ Predicted by SignalP program. 


\section{Strongly up-regulated secretion of adipocyte markers during differentiation} Complement $\mathrm{C} 3$ that was detected at a low level in the medium of preadipocytes clearly increased during differentiation. Adipsin was also detected, but only in the medium of day 8 and 12, as two groups of spots within a pI range of 3.5-4.5 at \pm 41 and $\pm 48 \mathrm{kDa}$, respectively (fig. 1B, spot ID 15). This is in line with the already reported glycosylation [20], but also suggests additional forms of post-translational modification. Adiponectin was identified as well (fig. 2 A, B) and followed the same secretion pattern as adipsin. Although different forms of adiponectin have been reported, only one form was detected by us which was shown to be glycosylated by the presence of a mass peak of 1679 in the spectrum [21]. The secretion of adiponectin was only blocked by BFA. Treatment of $20^{\circ} \mathrm{C}$ instead seemed to increase the secretion somehow (fig. 2C), as was confirmed by $1 \mathrm{D}$ Western blotting (fig. 2D).

\section{Different changes of extracellular matrix components and their modifying proteins} during adipocyte differentiation Collagens made an important contribution to the secretion profile of 3T3-L1 cells, since they represented 106 out of 193 analyzed spots. These spots belong to eight different proteins related to five types of collagen. All types of collagen were secreted at any time point during differentiation but with a different profile. Collagens I and III were found as major types in both preadipocyte and adipocyte medium. The summed intensities of spots of these types of collagen generally showed first a decrease and then an increase during differentiation. At day 12, the level of secretion per cell of these two types of collagen was again that of day 0 (fig. 3 ). The level of secretion of collagens IV, V and VI showed an increase during differentiation (fig. 3). We also identified four proteins that are involved in the process of collagen modification and degradation: matrix metalloproteinase-2, metalloproteinase inhibitor 2 , procollagen C-proteinase enhancer protein, and protein-lysine 6-oxidase. For those proteins also, the secretion level was found to change during differentiation (fig. 3). Another extracellular matrix component SPARC (osteonectin), a modulator of cell matrix interaction and collagen synthesis [22], was strongly up-regulated during differentiation, in line with previous reports $[5,8]$.

Secretion patterns of growth-modulating factors during differentiation The growth-modulating factors galectin-1, cyclophilin A and C, stromal cell-derived growth factor SF20/IL-25, MIF, pigment epithelium derived factor (PEDF) and prohibitin were identified in our experiments (table 1, fig. 4). The secretion of the first four of these proteins was clearly up-regulated during differentiation, whereas the secretion of prohibitin, a known negative regulator of growth, decreased at day 12 to about half of its level compared with that at day 0. For MIF, the pattern could not be determined by 2D gel analysis because it was mixed with beta- 2 microglobulin as detected by LCMS/MS. The fragments of PEDF corresponding to the C- and N-terminal half of the protein showed a similar pattern as collagens I and III. For the complete protein, the pattern could not be determined by 2D gel analysis because it was in an area of high abundant spots, but Western blotting revealed the same pattern as for the fragments (data not shown). 

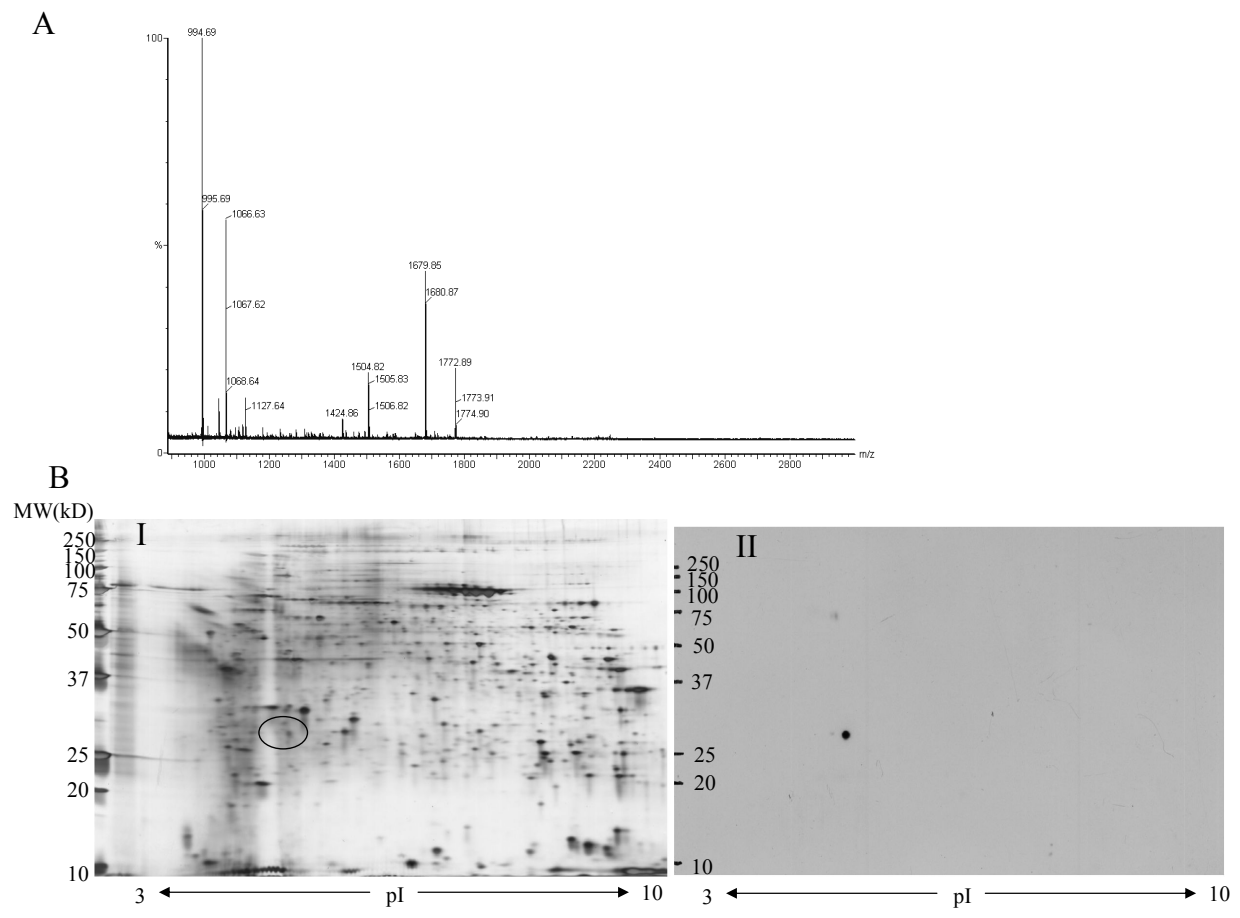

$\mathrm{C}$

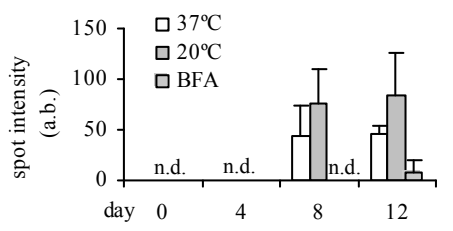

$\mathrm{D}$

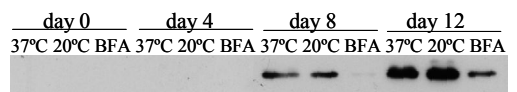

Fig. 2. Identification of adiponectin and its secretion during 3T3-L1 adipocyte differentiation under unblocked and blocked conditions. (A) MALDI-TOF mass spectrum of tryptic peptide mixture derived from adiponectin. (B) Spot detection on 2D Western blot. One gel loaded with 15 $\mu \mathrm{g}$ proteins derived from $5.7 \times 10^{5}$ day 8 adipocytes was silver-stained (I). Another gel loaded with $7.5 \mu \mathrm{g}$ proteins was blotted and probed with an anti-adiponectin antibody (II). The area of the adiponectin spot is circled. (C) Secretion levels of adiponectin detected by $2 \mathrm{D}$ gel on day 0,4 , 8,12 of differentiation, at $37^{\circ} \mathrm{C}, 20^{\circ} \mathrm{C}$, and with $20 \mu \mathrm{M}$ BFA, respectively. The values were expressed as the mean \pm SD of gel spot intensity in arbitrary units (a.b.) from three independent experiments; n.d., not detectable. (D) A representative 1D blot showing the secretion levels of adiponectin for the same conditions. Every lane was loaded with medium proteins derived from 5 $\mathrm{x} 10^{4}$ cells. 


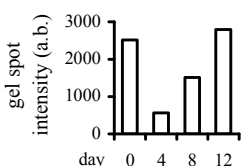

collagen type I alpha 1

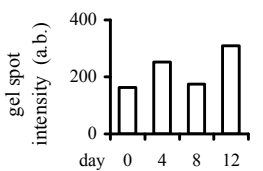

matrix metalloproteinase-2

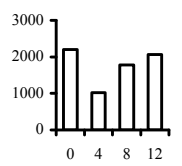

collagen type I alpha 2

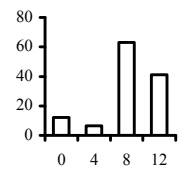

metalloproteinase inhibitor 2

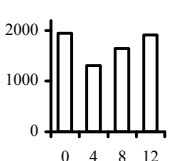

collagen type III alpha 1

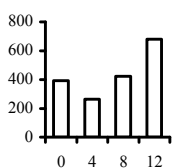

procollagen C-

proteinase enhancer protein

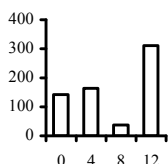

collagen type IV alpha $1 / 2$

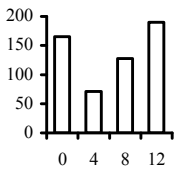

protein-lysine 6-

oxidase /enolase fragment/collagen type I alpha $2 \mathrm{C}$ peptide

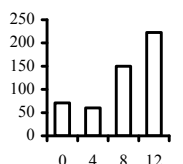

collagen type $\mathrm{V}$ alpha 1

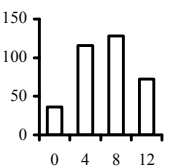

collagen type VI alpha $1 / 2$

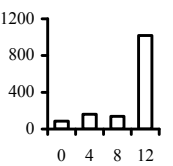

SPARC

(osteonectin)

Fig. 3. Secretion levels of extracellular matrix components and related proteins from 3T3-L1 cells during differentiation. Medium was sampled at $37^{\circ} \mathrm{C}$ without BFA on day $0,4,8$, and 12 during differentiation. The gel intensity of one protein in arbitrary units (a.b.) was expressed as the sum of the gel intensities of all spots containing this protein. The gel intensity of each spot is the mean from three independent experiments.
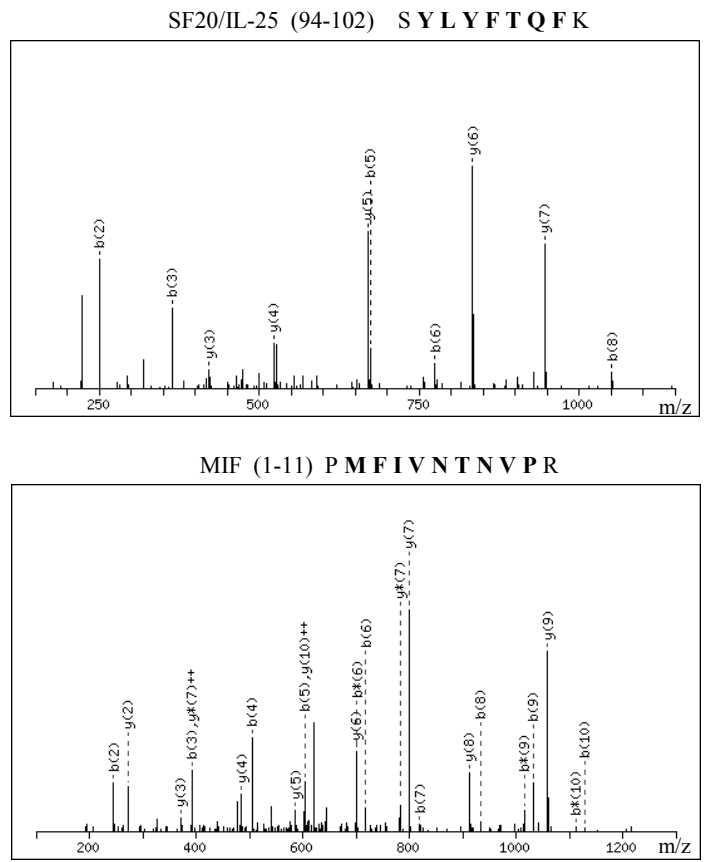

Fig. 4. LC-MS/MS identification of SF20/IL-25 and MIF. Spectra were obtained as indicated in Materials and methods. 
Other proteins secreted by 3T3-L1 cells during differentiation The acute-phase reactant haptoglobin and the self-defense protein beta- 2 microglobulin were identified in the medium at day 12, but they appeared on the gel as mixed spots with a fragment of transitional endoplasmic reticulum ATPase and with MIF, respectively. Of these, haptoglobin was not yet present at day 0 . We identified two proteins, extracellular superoxide dismutase and peroxiredoxin 1, presenting as antioxidants in the medium of adipocytes. Both were hardly detectable at day 0 , but showed strong up-regulation toward day 12. According to our criteria, a component of the cytoskeleton, a fragment of gamma-actin, and two actin filament modulators, cofilin and gelsolin (table 1), were identified as secreted factors. While these three proteins showed an increase in secretion level between day 0 and 12, gelsolin reached its highest level at day 4 .

Finally, a ribonucleosome component, heterogeneous nuclear ribonucleoprotein A2/B1, was found to be present in the medium and strongly up-regulated upon differentiation (table 1).

Cellular proteins in the medium responding to $20^{\circ} \mathrm{C}$ or $\mathrm{BFA}$ treatment $\mathrm{We}$ clustered the spots that showed the highest expression at day 4 , when the cells were easy to detach from the culture dish during incubation with the serum-free medium, and that were only blocked by the $20^{\circ} \mathrm{C}$ treatment. Three cellular proteins met these criteria (table 1), whose presence in the medium was possibly due to cell leakage, as discussed below. We observed an additional group of cellular proteins among the potentially secreted factors, which are involved in protein synthesis and transport or which are membrane proteins. However, these were all identified from mixed spots (table 1). Only stress-70 protein and adhesion- regulating molecule 1 have a potential signal peptide, and therefore might be true secreted proteins.

\section{Discussion}

We used a systematic proteomic approach with secretion blocking and identified novel secreted proteins during 3T3-L1 adipocyte differentiation. Previously, Kratchmarova et al. [8] identified a number of factors secreted by 3T3-L1 adipocytes, some of which were also found here. In contrast to our findings, they reported a downregulation of PEDF and identified haptoglobin as a major secreted protein. The HCNP precursor protein was also detected by us, but with a less than twofold change during differentiation. The differences between the studies may be due to the experimental approach or to the analysis of different subtypes of these proteins.

Efficacy and limitations of the approach The validity of our procedure was demonstrated by the detection of several known adipocyte-specific secreted proteins: complement C3, adiponectin and adipsin. The efficacy of the blocking method was confirmed by Western blot analysis of adiponectin (fig. 2) and PEDF (not shown). Nevertheless, some spots contained more than one protein, obscuring the secretion pattern of individual proteins. At day 4 under serum-free conditions, we observed a considerable number of floating cells at $37^{\circ} \mathrm{C}$, but not at $20^{\circ} \mathrm{C}$. In addition, the protein 
concentration of the harvested medium was highest at $37^{\circ} \mathrm{C}$ at day 4 , indicating that the detachment of cells might be associated with increased leakage of cellular proteins. Using the $20^{\circ} \mathrm{C}$ treatment as a single selection criterion, cellular proteins with the highest expression in the medium at day 4 might be aberrantly categorized as being secreted. For some cellular proteins, fragments were observed to be blocked by both $20^{\circ} \mathrm{C}$ and BFA. This may be due to the differential expression of proteinases, which by themselves are blocked by these treatments.

Some well-known adipokines, including leptin, resistin, plasminogen activator inhibitor-1, vascular endothelial growth factor, and collagen type VI alpha 3, were not identified. This can be explained in several ways. Like leptin, they may have a low abundance in the medium of 3T3-L1 adipocytes and occur below the detection level of our system. 3T3-L1 cells may behave differently from in vivo (pre)adipocytes, but there is recent evidence that some adipokines and cytokines like interleukin-6 (Il-6) and tumor necrosis factor- $a$ are mainly expressed by other cells in the stromal-vascular part of adipose tissue and are not released by adipocytes [23, 24]. Furthermore, by 2D gel electrophoresis, only part of the secretory proteome is visualized. In addition, adipokines may occur as spots mixed with other prominent unblocked proteins. Finally, some proteins are possibly secreted in a way not affected by temperature or BFA.

\section{New features of extracellular proteins discovered by this blocking strategy A} number of new aspects of protein secretion during adipocyte differentiation were revealed. One of these is the different response of secreted proteins to the blocking conditions, which may reflect their different secretion pathways. The proteins whose secretion could not be blocked by BFA, such as galectin-1 [9], cyclophilin A and C, SF20/IL-25, and cofilin, are secreted through an ER/Golgi-independent pathway. Furthermore, the inconsistent blocking behavior of SF20/IL-25 suggests that mature 3T3-L1 adipocytes possess an additional secretion pathway, which is only present in adipocytes. In addition, our approach revealed unique features of adiponectin secretion by its positive response to $20^{\circ} \mathrm{C}$ treatment. The slightly up-regulated secretion of adiponectin at $20^{\circ} \mathrm{C}$ might relate to observations showing increased adiponectin mRNA and serum concentrations in mice exposed to cold [25].

There are two obvious routes by which proteins can end up in the extracellular space. One is through active secretion pathways, which may involve an N-terminal secretion signal peptide [9]. The other is through passive shedding of proteins with a transmembrane domain into the extracellular space by proteolytic enzymatic mechanisms [26]. We found that the structural analysis of a protein does not provide conclusive information about its intraor extracellular location, and that a functional assay like our blocking procedure has an important added value. For example, the structure of cyclophilin A does not give any indication about its secretion, but it has been reported as a secreted growth factor [27]. As described above, fragments of some cellular proteins might be shedded. One of those is alpha enolase, a well-known key enzyme in glycolysis with a single transmembrane helix as revealed by TMAP analysis. Indeed, alpha enolase has been reported as a cell surface protein [28, 29]. Our findings indicate that it is also present on 3T3-L1 adipocytes. There is evidence that the 
plasminogen cascade is required for adipocyte differentiation [30], in which alpha enolase can serve as a receptor of plasminogen.

Remodeling of the extracellular matrix in adipose tissue development During adipocyte differentiation, the cell morphology converts from a fibroblast-like to a spherical shape. This requires a dramatic remodeling of the extracellular matrix [13, 31$]$. The most obvious change was the dramatic reduction in fibrillar collagens I and III at the early stage of differentiation, which corresponds to the increased likelihood of cells to detach from the culture dish at day 4 in serum-free medium. The decrease in fibrillar collagens probably provides a more permissive environment for adipocyte expansion [32]. At later stages of differentiation, we observed a clear increase in fibrillar collagens. This regulated decrease and increase may explain some of the contradictory reports at the mRNA and protein levels [33-36]. In accordance with the in vivo basement membrane [37], we observed that the main component collagen IV is up-regulated during differentiation. Interestingly, the basement membrane may not only offer structural support to cells and tissues, but can also be an important regulator of vascularization [38] which is a fundamental aspect of adipose tissue development [39].

\section{Growth regulation as a new aspect of adipokines revealed by novel adipocyte-} secreted proteins Except for well-known adipocyte secreted proteins, such as complement $\mathrm{C} 3$, adiponectin, adipsin, osteonectin, several collagens, matrix metalloproteinase-2, metalloproteinase inhibitor 2, haptoglobin, and a housekeeping protein beta-2 microglobulin [40], our identification method confirmed five other secreted proteins that have been reported in only a very limited number of studies, such as MIF [41], protein-lysine 6-oxidase [42], extracellular superoxide dismutase [43], gelsolin, and PEDF [8]. Furthermore, five proteins were newly identified as adipocyte secreted factors that have previously been reported as being secreted by other cell systems: procollagen C-proteinase enhancer protein [44], galectin-1, cyclophilin A and C, and SF20/IL-25. Moreover, three proteins (with a signal peptide sequence) are reported here for the first time as secreted factors: prohibitin, stress-70 protein, and adhesion-regulating molecule 1 . Seven out of these 13 confirmed and newly identified secreted proteins have a function in growth regulation.

MIF as an inhibitor of the random migration of macrophages might play a role in the significant infiltration of macrophages into white adipose tissue as recently discovered [23]. MIF is associated not only with the immune response but also with cell growth and differentiation during wound healing and carcinogenesis [45].

PEDF is a member of the serine protease inhibitor superfamily [46]. It is highly expressed in human adipose tissue [47] and may function in anti-angiogenesis and innervation $[48,49]$. We observed that 3T3-L1 cells secrete about the same amount of PEDF per cell at day 0 and day 12 , but much less at day 4 . This pattern is different from the previous report [8] but in line with that of collagens I and III, to which PEDF specifically binds in vitro [50]. Galectin-1 is expressed in a wide variety of cells and tissues including adipose tissue. Under different circumstances, it acts as a mitogen or as an inhibitor of cell proliferation, differentiation, and apoptosis [51]. The increasing 
secretion of galectin-1 during 3T3-L1 differentiation suggests an active involvement in adipose tissue development.

Cyclophilin $\mathrm{A}$ and $\mathrm{C}$ are intracellular immunophilin family proteins known to be distributed ubiquitously. They have peptidyl-prolyl cis-trans isomerase activity and act as molecular chaperones [52, 53]. Cyclophilin A does not have the structural characteristics for secretion, but was reported to be secreted from vascular smooth muscle cells as an autocrine growth factor [27] and from macrophages [54]. We observed first an up-, then a down-regulation of cyclophilin A during adipocyte differentiation. However, these quantifications may have been affected by some leakage of the cellular protein pool.

SF20/IL-25, like cyclophilin C, was also originally isolated from a mouse bone marrow stromal cell line [55]. In vitro findings indicated that this growth factor supports proliferation of lymphoid cells. However, these results could not be reproduced [56]. We have found that it is strongly up-regulated between days 0 and 4 of adipocyte differentiation and maintained at a high level throughout the differentiation process, indicating that this growth factor could be involved in adipogenesis and adipose tissue development.

Prohibitin is a fundamentally important gene ubiquitously expressed from yeast to humans and originally identified as an inhibitor of DNA synthesis [57]. It was detected in the mitochondria inner cell membrane and the nucleus. Recently, it has been established as a vascular (membrane) maker of adipose tissue in mouse and humans [58]. Our result shows that prohibitin is secreted into the medium of both preadipocytes and adipocytes, and that its concentration levels off at day 12 . The presence of a possible signal peptide sequence is in line with our finding, but its function in the extracellular space, like its function on the cell surface, remains unknown.

Adhesion-regulating molecule 1 was discovered as a novel cell adhesion-promoting factor that was upregulated in breast cancer cells [59]. Our 2D gel experiment showed its presence in 3T3-L1 adipocyte medium, but did not provide more information about its blocking behavior and regulation, because it was in a mixed spot.

From the above descriptions, we can conclude that differentiating adipocytes secrete proteins that are able to stimulate or inhibit the growth of immune cells, vascular endothelium cells, neuronal cells or tumor cells. From those factors for which the secretory profile was determined, the positive factors, galectin-1, cyclophilin A and C, and SF20/IL-25, were up-regulated, and the negative factor prohibitin was downregulated. In vivo, therefore, these factors are likely involved in regulating defined processes associated with adipose tissue development like vascularization and innervation.

Most of these growth factors have been shown to play different roles in tumor development, including proliferation (SF20/IL-25) [55, 56], invasion (galectin-1) [60], and angiogenesis (MIF) [61]. The addition of 3T3-L1 adipocyte-derived secreted factors to breast cancer cells in vitro induced transcriptional programs of tumorigenesis including increased cell proliferation, invasive potential, survival, and angiogenesis, and type VI collagen was identified as a critical factor in this effect [62]. We therefore 
propose that the above-mentioned factors may also contribute to the tumorigenic potential of 3T3-L1 adipocytes. One should note that (some of) the tumor-related activities might merely be due to the immortalized nature of 3T3-L1 cells. However, the fact that the secretion profile of these factors changes during adipocyte differentiation implies that their secretion is a true characteristic of adipogenesis.

\section{Conclusion}

In conclusion, we have performed protein profiling with 2D gel electrophoresis and MS to study the secretion profiles of 3T3-L1 adipocytes during differentiation, using BFA and temperature blocking to distinguish between active secretion and leakage. Secretion profiles were determined, indicating a dynamic environment including an actively remodeling ECM and several factors involved in growth regulation. In addition, several new secreted proteins were discovered by this strategy, whose biological functions can now be further explored.

Acknowledgements We thank Dr. E. Smit and Mr. A. Zorenc of the Department of Human Biology, Maastricht University for helpful discussions. Mr. E. Royackers of the Biomedical Research Institute, The Transnational University Limburg is acknowledged for technical assistance in LC-MS/MS analysis. This work was supported by the Centre for Human Nutrigenomics in The Netherlands.

\section{References}

1. Caballero A. E. (2003) Endothelial dysfunction in obesity and insulin resistance: a road to diabetes and heart disease. Obes.Res. 11: 1278-1289

2. Calle E. E., Rodriguez C., Walker-Thurmond K. and Thun M.J. (2003) Overweight, obesity, and mortality from cancer in a prospectively studied cohort of U.S. adults. N. Engl. J. Med. 348: 1625-1638

3. Rajala M. W. and Scherer P. E. (2003) Minireview: the adipocyte - at the crossroads of energy homeostasis, inflammation, and atherosclerosis. Endocrinology 144: 3765-3773

4. Mohamed-Ali V., Pinkney J. H. and Coppack S. W. (1998) Adipose tissue as an endocrine and paracrine organ. Int. J. Obes. Relat. Metab. Disord. 22: 1145-1158

5. Scherer P. E., Bickel P. E., Kotler M. and Lodish H. F. (1998) Cloning of cell-specific secreted and surface proteins by subtractive antibody screening. Nat. Biotechnol. 16: 581-586

6. Tsuruga H., Kumagai H., Kojima T. and Kitamura T. (2000) Identification of novel membrane and secreted proteins upregulated during adipocyte differentiation. Biochem. Biophys. Res. Commun. 272: 293-297

7. Yang Y. S., Song H. D., Li R. Y., Zhou L. B., Zhu Z. D., Hu R. M. et al. (2003) The gene expression profiling of human visceral adipose tissue and its secretory functions. Biochem. Biophys. Res. Commun. 300: 839-846

8. Kratchmarova I., Kalume D. E., Blagoev B., Scherer P. E., Podtelejnikov A. V., Molina H. et al. (2002) A proteomic approach for identification of secreted proteins during the differentiation of 3T3-L1 preadipocytes to adipocytes. Mol. Cell Proteom. 1: 213-222

9. Nickel W. (2003) The mystery of nonclassical protein secretion: a current view on cargo proteins and potential export routes. Eur. J. Biochem. 270: 2109-2119

10. Orci L., Tagaya M., Amherdt M., Perrelet A., Donaldson J. G., Lippincott-Schwartz J. et al. (1991) Brefeldin A, a drug that blocks secretion, prevents the assembly of non-clathrin-coated buds on Golgi cisternae. Cell 64: 1183-1195

11. Hughes R. C. (1999) Secretion of the galectin family of mammalian carbohydrate-binding proteins. Biochim. Biophys. Acta. 1473: 172-185

12. Bradley R. L., Cleveland K. A. and Cheatham B. (2001) The adipocyte as a secretory organ: mechanisms of vesicle transport and secretory pathways. Recent Prog. Horm. Res. 56: 329-358 
13. Gregoire F. M., Smas C. M. and Sul H. S. (1998) Understanding adipocyte differentiation. Physiol. Rev. 78: 783-809

14. Bouwman F. G., Renes J. W. and Mariman E. C. M. (2004) A combination of protein profiling and isotopomer analysis using matrix-assisted laser Desorption /ionization-time of flight mass spectrometry reveals an active metabolism of the extracellular matrix of 3T3-L1 adipocytes. Proteomic 4: 3855-3863

15. Shevchenko A., Wilm M., Vorm O. and Mann M. (1996) Mass spectrometric sequencing of proteins from silver-stained polyacrylamide gels. Anal. Chem. 68: 850-858

16. Dumont D., Noben J. P., Raus J., Stinissen P. and Robben J.(2004) Proteomic analysis of cerebrospinal fluid from multiple sclerosis patients. Proteomics 4: 2117-2124

17. Welsh J. B., Sapinoso L. M., Kern S. G., Brown D. A., Liu T., Bauskin A. R. et al. (2003) Large-scale delineation of secreted protein biomarkers overexpressed in cancer tissue and serum. Proc. Natl. Acad. Sci. USA 100: 3410-3415

18. Nielsen H., Engelbrecht J., Brunak S. and Heijne G. von (1997) A neural network method for identification of prokaryotic and eukaryotic signal peptides and prediction of their cleavage sites. Int. J. Neural. Syst. 8: 581-599

19. Persson B. and Argos P. (1996) Topology prediction of membrane proteins. Protein Sci. 5: 363-371

20. Cook K. S., Min H. Y., Johnson D., Chaplinsky R. J., Flier J. S., Hunt C. R. et al. (1987) Adipsin: a circulating serine protease homolog secreted by adipose tissue and sciatic nerve. Science 237: 402-405

21. Wang Y., Xu A., Knight C., Xu L. Y. and Cooper G. J. (2002) Hydroxylation and glycosylation of the four conserved lysine residues in the collagenous domain of adiponectin: potential role in the modulation of its insulin-sensitizing activity. J. Biol. Chem. 277: 19521-19529

22. Motamed K. (1999) SPARC (osteonectin/BM-40). Int. J. Biochem. Cell Biol. 31: 1363-1366

23. Xu H., Barnes G. T., Yang Q., Tan G., Yang D., Chou C. J. et al. (2003) Chronic inflammation in fat plays a crucial role in the development of obesity-related insulin resistance. J. Clin. Invest. 112: 1821-1830

24. Fain J. N., Madan A. K., Hiler M. L., Cheema P. and Bahouth S. W. (2004) Comparison of the release of adipokines by adipose tissue, adipose tissue matrix, and adipocytes from visceral and subcutaneous abdominal adipose tissues of obese humans. Endocrinology 145: 2273-2282

25. Yoda M., Nakano Y., Tobe T., Shioda S., Choi-Miura N. H. and Tomita M. (2001) Characterization of mouse GBP28 and its induction by exposure to cold. Int. J. Obes. Relat. Metab. Disord. 25: 75-83

26. Mullberg J., Althoff K., Jostock T. and Rose-John S. (2000) The importance of shedding of membrane proteins for cytokine biology. Eur. Cytokine Netw. 11: 27-38

27. Jin Z. G., Melaragno M. G., Liao D. F., Yan C., Haendeler J., Suh Y. A. et al. (2000) Cyclophilin A is a secreted growth factor induced by oxidative stress. Circ. Res. 87: 789-796

28. Arza B., Felez J., Lopez-Alemany R., Miles L. A. and Munoz-Canoves P. (1997) Identification of an epitope of alpha-enolase (a candidate plasminogen receptor) by phage display. Thromb. Haemost. 78: 1097-1103

29. Pancholi V. (2001) Multifunctional alpha-enolase: its role in diseases. Cell. Mol. Life Sci. 58: 902-920

30. Selvarajan S., Lund L. R., Takeuchi T., Craik C. S. and Werb Z. (2001) A plasma kallikrein-dependent plasminogen cascade required for adipocyte differentiation. Nat. Cell Biol. 3: 267-275

31. Gregoire F. M. (2001) Adipocyte differentiation: from fibroblast to endocrine cell. Exp. Biol. Med. (Maywood) 226: 997-1002

32. Bradshaw A. D., Puolakkainen P., Dasgupta J., Davidson J. M., Wight T. N. and Sage E. H. (2003) SPARC-null mice display abnormalities in the dermis characterized by decreased collagen fibril diameter and reduced tensile strength. J. Invest. Dermatol. 120: 949-955

33. Kubo Y., Kaidzu S., Nakajima I., Takenouchi K. and Nakamura F. (2000) Organization of extracellular matrix components during differentiation of adipocytes in long-term culture. In Vitro Cell Dev. Biol. Anim. 36: 38-44

34. Weiner F. R., Shah A., Smith P. J., Rubin C. S. and Zern M. A. (1989) Regulation of collagen gene expression in 3T3-L1 cells: effects of adipocyte differentiation and tumor necrosis factor alpha. Biochemistry 28: 4094-4099

35. Nakajima I., Yamaguchi T., Ozutsumi K. and Aso H. (1998) Adipose tissue extracellular matrix: newly organized by adipocytes during differentiation. Differentiation 63: 193-200

36. Nakajima I., Muroya S., Tanabe R. and Chikuni K. (2002) Extracellular matrix development during differentiation into adipocytes with a unique increase in type V and VI collagen. Biol. Cell 94: 197-203

37. Pierleoni C., Verdenelli F., Castellucci M. and Cinti S. (1998) Fibronectins and basal lamina molecules expression in human subcutaneous white adipose tissue. Eur. J. Histochem. 42: 183-188

38. Kalluri R. (2003) Basement membranes: structure, assembly and role in tumour angiogenesis. Nat. Rev. Cancer 3: 422-433

39. Larson D. R., Zipfel W. R., Williams R. M., Clark S. W., Bruchez M. P., Wise F. W. et al. (2003) Watersoluble quantum dots for multiphoton fluorescence imaging in vivo. Science 300: 1434-1436 
40. Gorzelniak K., Janke J., Engeli S. and Sharma A. M. (2001) Validation of endogenous controls for gene expression studies in human adipocytes and preadipocytes. Horm. Metab. Res. 33:625-627

41. Sakaue S., Nishihira J., Hirokawa J., Yoshimura H., Honda T., Aoki K. et al. (1999) Regulation of macrophage migration inhibitory factor (MIF) expression by glucose and insulin in adipocytes in vitro. Mol. Med. 5: 361-371

42. Dimaculangan D. D., Chawla A., Boak A., Kagan H. M. andLazar M. A. (1994) Retinoic acid prevents downregulation of ras recision gene/lysyl oxidase early in adipocyte differentiation. Differentiation 58: $47-52$

43. Nakao C., Ookawara T., Sato Y., Kizaki T., Imazeki N., Matsubara O. et al. (2000) Extracellular superoxide dismutase in tissues from obese (ob/ob) mice. Free Radic. Res. 33: 229-241

44. Kessler E., Mould A. P. and Hulmes D. J. (1990) Procollagen type I C-proteinase enhancer is a naturally occurring connective tissue glycoprotein. Biochem. Biophys. Res. Commun. 173: 81-86

45. Nishihira J. (1998) Novel pathophysiological aspects of macrophage migration inhibitory factor (review). Int. J. Mol. Med. 2: 17-28

46. Becerra S. P., Sagasti A., Spinella P. and Notario V. (1995) Pigment epithelium-derived factor behaves like a noninhibitory serpin. J. Biol. Chem. 270: 25992-25999

47. Su A. I., Cooke M. P., Ching K. A., Hakak Y., Walker J. R., Wiltshire T. et al. (2002) Large-scale analysis of the human and mouse transcriptomes. Proc. Natl. Acad. Sci. USA 99: 4465-4470

48. Chader G. J. (2001) PEDF: raising both hopes and questions in controlling angiogenesis. Proc. Natl. Acad. Sci. USA 98:2122-2124

49. Bouck N. (2002) PEDF: anti-angiogenic guardian of ocular function. Trends Mol. Med. 8: 330-334

50. Kozaki K., Miyaishi O., Koiwai O., Yasui Y., Kashiwai A., Nishikawa Y. et al. (1998) Isolation, purification, and characterization of a collagen-associated serpin, caspin, produced by murine colon adenocarcinoma cells. J. Biol. Chem. 273:15125-15130

51. Scott K. and Weinberg C. (2004) Galectin-1: a bifunctional regulator of cellular proliferation. Glycoconj. J. 19: $467-477$

52. Galat A. (1993) Peptidylproline cis-trans-isomerases: immunophilins. Eur. J. Biochem. 216: 689-707

53. Gothel S. F. and Marahiel M. A. (1999) Peptidyl-prolyl cistrans isomerases, a superfamily of ubiquitous folding catalysts. Cell. Mol. Life Sci. 55: 423-436

54. Sherry B., Yarlett N., Strupp A. and Cerami A. (1992) Identification of cyclophilin as a proinflammatory secretory product of lipopolysaccharide-activated macrophages. Proc. Natl. Acad. Sci. USA 89: 35113515

55. Tulin E. E., Onoda N., Nakata Y., Maeda M., Hasegawa M., Nomura H. et al. (2001) SF20/IL-25, a novel bone marrow stromaderived growth factor that binds to mouse thymic shared antigen-1 and supports lymphoid cell proliferation. J. Immunol. 167: 6338-6347

56. Tulin E. E., Onoda N., Nakata Y., Maeda M., Hasegawa M., Nomura H. et al. (2003) SF20/IL-25, a novel bone marrow stromaderived growth factor that binds to mouse thymic shared antigen-1 and supports lymphoid cell proliferation. J. Immunol. 170: 1593, Retraction

57. McClung J. K., Jupe E. R., Liu X. T. and Dell'Orco R. T. (1995) Prohibitin: potential role in senescence, development, and tumor suppression. Exp. Gerontol. 30: 99-124

58. Kolonin M. G., Saha P. K., Chan L., Pasqualini R. and Arap W. (2004) Reversal of obesity by targeted ablation of adipose tissue. Nat. Med. 10: 625-632

59. Simins A. B., Weighardt H., Weidner K. M., Weidle U. H. and Holzmann B. (1999) Functional cloning of ARM-1, an adhesion-regulating molecule upregulated in metastatic tumor cells. Clin. Exp. Metastasis 17: $641-648$

60. He J. and Baum L. G. (2004) Presentation of galectin-1 by extracellular matrix triggers T cell death. J. Biol. Chem. 279:4705-4712

61. Nishihira J., Ishibashi T., Fukushima T., Sun B., Sato Y. and Todo S. (2003) Macrophage migration inhibitory factor (MIF): its potential role in tumor growth and tumor-associated angiogenesis. Ann. N. Y. Acad. Sci. 995: 171-182

62. Iyengar P., Combs T. P., Shah S. J., Gouon-Evans V., Pollard J. W., Albanese C. et al. (2003) Adipocytesecreted factors synergistically promote mammary tumorigenesis through induction of anti-apoptotic transcriptional programs and proto-oncogene stabilization. Oncogene 22: 6408-6423 
Chapter 2. Secreted proteins from 3T3-L1 adipocytes 


\section{Insulin modulates the secretion of proteins from mature 3T3-L1 adipocytes: a role for transcriptional regulation of processing}

P. Wang ${ }^{1,2}$, J. Keijer ${ }^{2}$, A. Bunschoten ${ }^{2}$, F. Bouwman ${ }^{1}$, J. Renes ${ }^{1}$, E. Mariman ${ }^{1}$

${ }^{1}$ Functional Genomics Group, Research Institute NUTRIM, Department of Human Biology, Maastricht University, Maastricht, the Netherlands, ${ }^{2}$ Food Bioactives Group, Rikilt-Institute of Food Safety, Wageningen, the Netherlands

Diabetologia. (2006) 49:2453-2462

DOI 10.1007/s00125-006-0321-5 


\begin{abstract}
Aims/hypothesis Under conditions of insulin resistance and type 2 diabetes, fat cells are subjected to increased levels of insulin, which may have a major impact on the secretion of adipokines.

Materials and methods Using transcriptomics and proteomics, we investigated how insulin affects the transcription and protein secretion profile of mature 3T3-L1 adipocytes.

Results We found that insulin has a significant impact on protein secretion of 3T3-L1 adipocytes. However, transcription is not the major regulation point for these secreted proteins. For extracellular matrix components, our data suggest that the mRNA level of processing enzymes, but not of target proteins, is the regulating point at which insulin stimulates secretion and function of the relevant proteins. Among these enzymes, we report a novel finding, namely that sulfatase 2 gene is regulated by insulin, which may induce a functional change in cultured adipocytes.

Conclusions/interpretation We propose that enhancement of protein processing and secretion rather than transcription of the secreted protein genes is part of the strategic role of insulin in the induction of cellular responses.
\end{abstract}

\title{
Keywords
}

Adipocytes . Insulin . Proteomics . Secretion . Transcriptomics

\section{Abbreviations}

1D: one-dimensional; 2D: two-dimensional; ECM: extracellular matrix; Glc: low insulin high glucose condition; HSPG: heparan sulfate proteoglycans; Ins: high insulin low glucose condition; Ins+Glc: high insulin high glucose condition; MALDI-TOF: matrix assisted laser desorption/ionisation-time of flight; P4ha1: procollagen-proline, 2oxoglutarate 4-dioxygenase (proline 4-hydroxylase), alpha 1; Pcolce: procollagen Cendopeptidase enhancer protein; PTM: post-translational modification; Q-PCR: quantitative real time RT-PCR analysis; Sulf 2: sulfatase 2. 


\section{Introduction}

Obesity is associated with insulin resistance and type 2 diabetes, implying that adipose tissue plays a role in the development of these disorders [1]. The primary function of adipose tissue is storage of fat, but it is also recognised as an active regulation centre, providing signals to guide metabolism. Well-known examples of signalling molecules MALDI-TOF (adipokines) secreted by adipose tissue are leptin, adiponectin, resistin and IL-6 [2]. Adipokine secretion is responsive to afferent messages to the fat cells [3]. Under conditions of insulin resistance and type 2 diabetes, fat cells are subjected to increased levels of insulin, which may have a major impact on the adipokines. A number of reviews have provided overviews of the relation between circulating levels of insulin and specific adipokines in rodents and humans [2, 4]. According to these, IL-6 and leptin have shown a consistently positive relation with insulin in various studies, while the response of resistin and adiponectin to insulin remains contradictory.

Often a high level of insulin is associated with hyperglycaemia. Only in the first stage of insulin resistance or at the later stage of type 2 diabetes do high insulin and high glucose not appear in parallel. As insulin targets, adipocytes respond to insulin by enhancing glucose uptake, which is impaired in insulin resistance and type 2 diabetes [5]. High levels of glucose alone may induce the production of inflammatory factors and acute phase reactants in adipocytes [6]. However, in in vivo investigations of obesity and type 2 diabetes, the contributions from high insulin and/or high glucose were hardly distinguished [2].

The effect of insulin on protein secretion has been addressed specifically in vitro using mouse 3T3-L1 adipocytes. It was shown that insulin can stimulate exocytosis of a regulated secretory compartment containing adiponectin, which is distinct from that containing type VI alpha 3 collagen [7]. Another study indicated that insulin stimulates the activity of the constitutive secretory pathway, possibly by increasing the activity of phospholipase D [8]. Despite the information obtained, these studies also showed that the mechanism of protein secretion regulation by insulin in adipocytes is complex and warrants further detailed study.

'Omics' technology provides powerful tools for expression profiling of biological events. Numerous studies have used genomics-approaches to investigate insulin actions in relation to insulin resistance and type 2 diabetes, but only few specifically addressed the effect of insulin on adipocyte secretion [9]. In our previous work we set up a twodimensional (2D) gel-secreted protein map of mouse 3T3- L1 adipocytes [10]. In addition to lipid metabolism regulators and growth factors, we found that the majority of secreted proteins belong to extracellular components and their related proteins. Here, using transcriptomics and proteomics, we investigated how insulin affects the transcription and protein secretion profile of mature 3T3-L1 adipocytes. As insulin stimulates glucose uptake and differences in intracellular glucose levels may affect gene expression, we performed our studies under conditions of low and high glucose. 


\section{Materials and methods}

Cell culture and sample preparation Murine 3T3-L1 fibroblasts (American Type Culture Collection, ATCC Number: CL-173) were cultured and differentiated to adipocytes in vitro as previously described [10], except that in the adipogenic cocktail 1 $\mu \mathrm{mol} / 1$ 15- deoxy- 1 12,14-prostaglandin J2 (Cayman Chemical, Ann Arbor, MI, USA) was used instead of $10 \mu \mathrm{mol} / 1$ prostaglandin I2 (Carbacyclin). On day 8 , differentiated cells grown in DMEM/F-12 (1:1) medium supplemented with $10 \%$ fetal calf serum (Perbio Science, Erembodegem, Belgium) were treated with $1 \mu \mathrm{mol} / 1$ insulin (cat. no. I 1882; Sigma, Zwijndrecht, the Netherlands) and $4.5 \mathrm{mmol} / 1$ glucose (high insulin low glucose condition [Ins]) or $15.75 \mathrm{mmol} / 1$ glucose (high insulin high glucose condition [Ins + Glc]). In parallel, control cells were cultured in the same medium with $4.5 \mathrm{mmol} / \mathrm{l}$ glucose alone (Basal) or $15.75 \mathrm{mmol} / 1$ glucose alone (low insulin high glucose condition, [Glc]). Each condition had quadruplicates. The Ins vs Basal conditions were used to monitor the effect of insulin at the low glucose level; the Ins+Glc vs Glc conditions were used to do the same at the high glucose level. On day 10, two replications with approximately $2.6 \times 10^{6}$ cells of all conditions were collected separately for total RNA isolation using Trizol (Invitrogen, Breda, the Netherlands) according to the manufacturer's instruction, and after chloroform extraction, an extraction of phenol: chloroform: isoamylalcohol (25:24:1), followed by a chloroform extraction, was added. Quality and quantity of total RNA were checked by spectrophotometer and agarose gel. Cells of the two other replications with approximately $7 \times 10^{6}$ cells were washed and incubated with the corresponding serum-free medium, supplemented with $2.2 \mathrm{mg} / \mathrm{l}$ transferrin and $10.6 \mathrm{nmol} / \mathrm{l}$ sodium selenite, for $6 \mathrm{~h}$. The number of cells was counted and culture medium proteins were collected, dialysed, lyophilised and dissolved as described before [10]. The duplicated protein samples were pooled for later analysis. Three independent experiments were performed.

Microarray The mouse 50-mer 10K_A oligo set (MWG, Ebersberg, Germany) and additional 50-mer oligonucleotides of genes encoding secretory proteins and proteins involved in energy metabolism were printed in-house on GAP II-coated glasses (Corning, Acton, MA, US) using a Microgrid II arrayer (BioRobotics, Cambridge, UK). A total of 10117 (10060 non-redundant) mouse oligo probes was arrayed. In addition to the manufacturer's annotation, the oligonucleotides were further annotated with Gene Ontology using SOURCE (http://smd.stanford.edu/cgi-bin/source/sourceBatchSearch, last accessed 28 October 2005).

We used five total RNA samples of three independent experiments per condition for hybridisation of the oligo DNA arrays as described [11]. For this, total RNA samples were reverse transcribed ( $45 \mu \mathrm{g}$ scale) to cDNA and labelled with Cy5 using a direct labelling method as described [12]. A pool of total RNA from all samples labelled with Cy3 was used as a 1:1 (v/v) reference in the hybridisations. The signals were captured by ScanArray Express HT (PerkinElmer Life Sciences, Billerica, MA, US) at 90\% laser power and $60 \%$ photomultiplier tube voltage. 
Microarray data analysis The data were extracted (medium density) using ArrayVision (version 7.0, Imaging Research, St Catharines, ON, Canada). The overall quality of the slides was checked both by visual inspection and Bland-Altmen plots. Next, the eligible array data were exported into GeneMaths XT (Applied Maths, SintMartens-Latem, Belgium). Spots with an average intensity, over all arrays, of lower than two-fold above average background were removed from further analysis. Then, the Cy5 intensities of the remaining 4019 spots were normalised against the $\mathrm{Cy} 3$ reference exactly as described [11]. The differences between samples were visualised using GeneMaths embedded discriminant analysis. This is a supervised form of principal component analysis, based on all expression data, and in which samples are first assigned to their treatment group and then separated along the dimension of maximum variation in gene or protein expression between the groups. Individual spots with a signal more than two-fold different from the average of the replicates $(n=5)$ were excluded and flagged. Fold change calculations and Student t-tests were performed in Microsoft Excel. Fold change equals ratio in the case of increase or equals $-1 /$ ratio in the case of decrease. Cut-off criteria for differential expression was set at a fold change of $>1.3$ and $p<0.05$. For genes with replicated spots, the average value of individual spots was used.

Quantitative real-time RT-PCR All six total RNA samples per treatment were used in quantitative real-time RT-PCR analysis (Q-PCR) of 18 genes (primer information, see Supplementary Table 1). After cDNA synthesis using an iScript kit (Bio-Rad, Veenendaal, the Netherlands), Q-PCR was conducted in iQ SYBR Green Supermix (MyiQ Single- Color Real-Time PCR Detection System; Bio-Rad), according to the manufacturer's instructions. The standard curve method was used in Q-PCR data analysis. Ribosomal protein S15 was selected as reference gene on the basis of its constant expression behaviour on the array.

One- and two-dimensional gel electrophoresis Protein samples obtained from $2.4 \times 10^{6}$ cells of each condition were analysed by 2D gel electrophoresis as described [10]. The data were obtained from PDQuest (version 7.2; Bio-Rad) and the gel density was normalised on the basis of total quantity in a spiked set of molecular weight markers. The gels were matched to a secreted protein reference map for 3T3-L1 adipocytes [10] and 99 secreted spots of $<85 \mathrm{kDa}$ were matched. The data were exported into GeneMaths for discriminant principal component analysis. A 1.8-fold change was taken as cut-off for regulation. Protein samples obtained from $2.2 \times 10^{5}$ cells were separated using 18-cm one-dimensional (1D) SDS PAGE (Protean II XL; Bio-Rad) to analyse high-molecularweight proteins. After silver staining [10], gel images were obtained with a GS-800 calibrated densitometer and analysed with Quantity One (Bio-Rad). An adipocyte medium protein sample treated with Brefeldin A [10] was loaded on the same gel, to verify protein secretion. Protein bands were excised and identified by matrix assisted laser desorption/ionisation-time of flight (MALDI-TOF) mass spectrometry [13]. 


\section{Results}

Insulin generates minor changes in the transcriptome of mature adipocytes in vitro To investigate the effect of insulin on mature adipocytes, 3T3-L1 adipocytes were cultured for 2 days with $1 \mu \mathrm{mol} / \mathrm{l}$ insulin with either high glucose or low glucose. For reference, cells were cultured with high or low glucose only. The morphology of the adipocytes as examined by light microscopy was similar for all four conditions. Total RNA samples from three independent experiments, performed in duplicate for each of the four conditions, were individually hybridised against a common reference pool on oligo DNA arrays. Two arrays were excluded from the analysis for quality reasons, one for Ins+Glc and the other for Ins. A total of 4019 of 10117 probes with average signals higher than two-fold over the background signal and representing 3718 non-redundant genes were used for further data analysis. The comparison between the insulin and noninsulin treatment at the same glucose level showed minor changes in the transcriptome. No gene changed $>2$-fold in either comparison. Of the probe signals, $92.4 \%$ (low glucose) or $90.4 \%$ (high glucose) were in the range of -1.2 - to 1.2 -fold.

Using a fold change of 1.3 and a $p$ of 0.05 as cut-off, 105 genes were found to be differentially expressed in mature adipocytes by insulin treatment at low or high glucose levels (Fig. 1). The overlap of the insulin-regulated gene list between low and high glucose levels was small, indicating an influence of glucose on the effect of insulin. We used Q-PCR to confirm the mRNA change for 12 of the differentially expressed genes and six of their family members. A good correlation between array and Q-PCR data was found $\left(\mathrm{R}^{2}=0.803\right)$. Three examples, procollagenproline, 2-oxoglutarate 4-dioxygenase (proline 4-hydroxylase), alpha 1 (P4ha1), procollagen C-endopeptidase enhancer protein (Pcolce) and sulfatase 2 (Sulf2), are shown (Fig. 2).

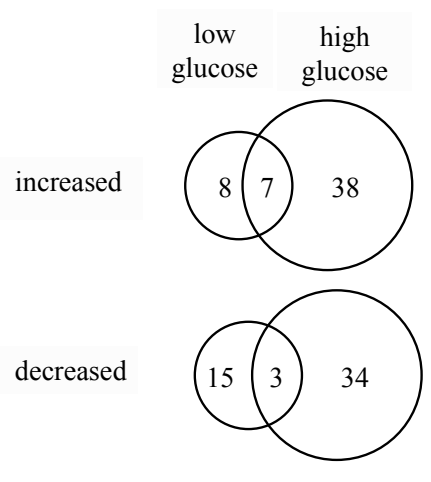

Fig. 1 Number of genes regulated by insulin at low and high glucose level. Based on microarray data, insulin and basal conditions were compared to obtain the number of regulated genes for the low glucose level; insulin+glucose and glucose conditions were compared for the high glucose level. Cut-off criteria: fold change $>1.3$ and t-test $\mathrm{p}<0.05$ 

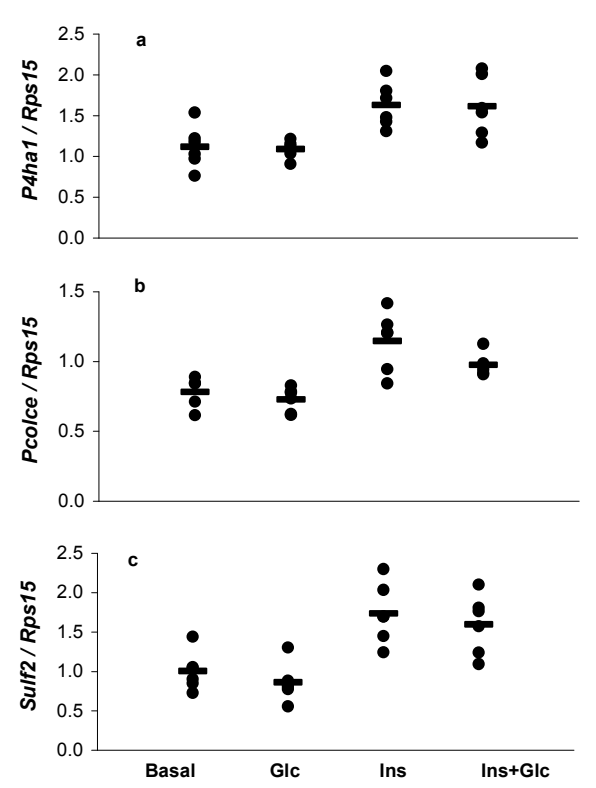

Fig. 2 Expression levels of genes involved in protein processing measured by quantitative realtime PCR, relative to ribosomal protein S15 (Rps15) expression. Dots, individual samples; bars, group average $(n=6)$. The fold change of Ins/Basal and Ins + Glc/Glc, respectively, were for: (a) P4ha1 $1.46(p=0.008)$ and $1.48(p=0.016)$; (b) Pcolce $1.47(p=0.007)$ and $1.34(p=0.001)$; and (c) Sulf2 $1.73(p=0.004)$ and $1.86(p=0.003)$

The 105 differentially expressed genes were clustered into ten functional groups based on Gene Ontology annotations (Fig. 3). One additional group consisted of genes with unknown function. The largest group was that of structural proteins and related enzymes, consisting of genes with a functional annotation of cytoskeleton, cell adhesion and extracellular matrix (ECM) (Table 1). All genes of this functional group were upregulated, except cysteine-rich protein 61. Sulf2, an extracellular endosulfatase, showed the largest increase in response to insulin (1.8-fold). This was not influenced by the glucose state. Glucose alone had no effect on its expression (Table 1 and Fig. 2). The up-regulation of proteolysis inhibitors, tissue inhibitor of metalloproteinases (Timp1 and Timp4), implies reduced degradation of ECM components. The next major functional group was related to protein expression. However, the upregulation or downregulation of individual genes involved in mRNA processing and protein synthesis, folding, modification and transport gave an inconsistent picture of the effect of insulin on protein expression in general. For all groups the insulin effect was more explicit with high glucose than with low glucose, while glucose itself had no direct effect on the expression of most of these genes. This implies that regulation of these processes by insulin is dependent on the level of glucose. 


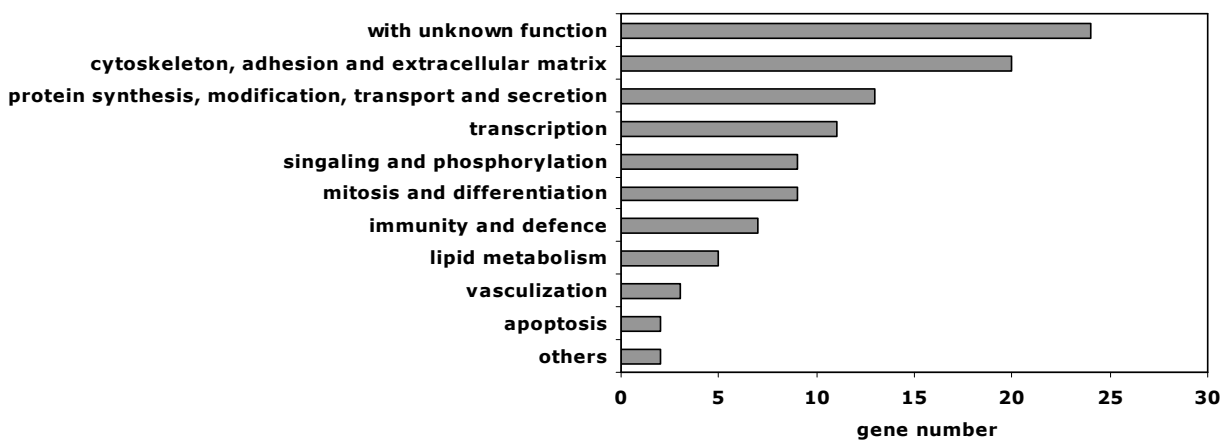

Fig. 3 Functional categories of genes regulated by insulin

We analysed the expression of 38 genes on the array and involved in insulin signalling pathways and found no significant effect (Supplementary Table 2). Since insulin signal transmission occurs mostly via phosphorylation of the proteins, it is not surprising that our data showed no significant influence on mRNA levels. One exception was phosphatidylinositol 3-kinase, regulatory subunit, polypeptide 2 (p85 beta), which was upregulated by insulin (fold change $=1.22, p=0.046$ and fold change $=1.39, p=0.011$ at low and high glucose, respectively). It has been reported that $\mathrm{p} 85$ beta negatively regulates the downstream signalling of phosphatidylinositol 3-kinase [14]. Therefore, the up-regulation of p85 beta suggests an attenuation of particular insulin signalling pathways.

Insulin modulates protein secretion from mature adipocytes in vitro No clear effect of insulin was seen on the expression of genes encoding secreted proteins or proteins involved in secretion pathways. To assess whether this would also be the case at the protein level, we also analysed the secreted proteins of an identical set of experiments performed in parallel to those described for mRNA expression analysis using $2 \mathrm{D}$ gel electrophoresis. Using a secretory protein map of 3T3-L1 adipocytes [10], we identified 86 secreted spots corresponding to 37 genes in the 10 to $85 \mathrm{kDa}$ range. High molecularweight proteins were left out of the analysis due to overall low resolution in the highmolecular-weight part of the gel. A strong effect of insulin on the expression of secreted proteins was detected. A total of 63 spots $(73.3 \%)$ corresponding to 29 genes $(78.4 \%)$ were upregulated or downregulated by insulin at either high or low glucose level. The majority of the secreted proteins were affected at both high and low glucose levels (Table 2). The most dominant change in the secretion profile was the increase of the Cpeptides of collagen type I and III, which are the processing by-products of fibrillar collagens (Fig. 4). 
Table 1 Expression of cytoskeleton, adhesion and extracellular matrix genes regulated by insulin

\begin{tabular}{|c|c|c|c|c|c|c|c|c|c|}
\hline \multirow[t]{2}{*}{ Function } & \multirow[t]{2}{*}{ Symbol } & \multirow[t]{2}{*}{ GeneID } & \multirow[t]{2}{*}{ Name } & \multicolumn{2}{|c|}{ Ins/Basal } & \multicolumn{2}{|c|}{$\mathrm{Ins}+\mathrm{Glc} / \mathrm{Glc}$} & \multicolumn{2}{|c|}{ Glc/Basal } \\
\hline & & & & $\mathrm{FC}$ & $p$ & $\mathrm{FC}$ & $p$ & $\mathrm{FC}$ & $p$ \\
\hline \multicolumn{10}{|l|}{ Cytoskelton } \\
\hline & Tubb6 & 67951 & Tubulin, beta 6 & 1.18 & 0.302 & 1.36 & 0.025 & -1.14 & 0.230 \\
\hline Actin binding & Cnn3 & 71994 & Calponin 3 , acidic & 1.30 & 0.007 & 1.29 & 0.018 & -1.10 & 0.230 \\
\hline Actin binding & Tagln 2 & 21346 & Transgelin 2 & 1.40 & 0.033 & 1.45 & 0.011 & -1.13 & 0.336 \\
\hline \multicolumn{10}{|l|}{ Adhesion } \\
\hline & Postn & 50706 & $\begin{array}{l}\text { Periostin, osteoblast specific } \\
\text { factor }\end{array}$ & 1.32 & 0.049 & 1.38 & 0.044 & -1.23 & 0.170 \\
\hline & $\operatorname{Itga} 5$ & 16402 & Integrin alpha 5 & 1.11 & 0.365 & 1.42 & 0.001 & -1.28 & 0.061 \\
\hline & Cyr61 & 16007 & Cysteine-rich protein 61 & -1.01 & 0.880 & -1.41 & 0.035 & 1.38 & 0.035 \\
\hline & $S d c 1$ & 20969 & Syndecan 1 & 1.22 & 0.187 & 1.51 & 0.006 & -1.29 & 0.091 \\
\hline & Cspg2 & 13003 & $\begin{array}{l}\text { Chondroitin sulfate } \\
\text { proteoglycan } 2\end{array}$ & 1.51 & 0.002 & 1.33 & 0.198 & 1.11 & 0.315 \\
\hline $\begin{array}{l}\text { Poteoglycan } \\
\text { synthesis }\end{array}$ & Chst2 & 54371 & $\begin{array}{l}\text { Carbohydrate sulfotransferase } \\
2\end{array}$ & 1.39 & 0.013 & 1.31 & 0.045 & -1.13 & 0.240 \\
\hline $\begin{array}{l}\text { Proteoglycan } \\
\text { hydrolysis }\end{array}$ & Sulf2 & 72043 & Sulfatase 2 & 1.76 & 0.013 & 1.73 & 0.009 & -1.02 & 0.804 \\
\hline \multicolumn{10}{|l|}{ Extracellular matrix } \\
\hline & $T g f b i$ & 21810 & $\begin{array}{l}\text { Transforming growth factor, } \\
\text { beta induced }\end{array}$ & 1.35 & 0.005 & 1.12 & 0.024 & -1.18 & 0.012 \\
\hline & Col5al & 12831 & Procollagen, type V, alpha 1 & 1.11 & 0.290 & 1.32 & 0.018 & -1.10 & 0.334 \\
\hline & Col6a3 & 12835 & Procollagen, type VI, alpha 3 & 1.25 & 0.001 & 1.47 & 0.009 & -1.09 & 0.131 \\
\hline & Col6a2 & 12834 & Procollagen, type VI, alpha 2 & 1.11 & 0.116 & 1.31 & 0.029 & -1.06 & 0.401 \\
\hline & Col5a3 & 53867 & Procollagen, type V, alpha 3 & 1.09 & 0.209 & 1.39 & 0.044 & -1.26 & 0.073 \\
\hline Collagen process & P4hal & 18451 & $\begin{array}{l}\text { Procollagen-proline 4- } \\
\text { hydroxylase alpha } 1 \\
\text { polypeptide }\end{array}$ & 1.27 & 0.038 & 1.32 & 0.000 & -1.00 & 0.904 \\
\hline Collagen process & Loxl1 & 16949 & Lysyl oxidase-like 1 & 1.25 & 0.064 & 1.31 & 0.005 & 1.00 & 0.942 \\
\hline Collagen process & Pcolce & 18542 & $\begin{array}{l}\text { Procollagen C-endopeptidase } \\
\text { enhancer protein }\end{array}$ & 1.22 & 0.082 & 1.36 & 0.017 & -1.12 & 0.332 \\
\hline $\begin{array}{l}\text { Proteolysis } \\
\text { inhibitor }\end{array}$ & Timp1 & 21857 & $\begin{array}{l}\text { Tissue inhibitor of } \\
\text { metalloproteinase } 1\end{array}$ & 1.05 & 0.595 & 1.35 & 0.038 & -1.22 & 0.188 \\
\hline $\begin{array}{l}\text { Proteolysis } \\
\text { inhibitor }\end{array}$ & Timp4 & 110595 & $\begin{array}{l}\text { Tissue inhibitor of } \\
\text { metalloproteinase } 4\end{array}$ & 1.67 & 0.010 & 1.28 & 0.006 & 1.03 & 0.607 \\
\hline
\end{tabular}

The expression, fold change (FC) and t-test $\mathrm{p}$ value (p) were calculated from microarray analysis $(n=5)$ 
To obtain information on the high-molecular weight secretion profile, we used 1D gel electrophoresis. Three bands that showed differential expression and were verified as secreted by brefeldin A [10] were identified by MALDITOF mass spectrometry. They contain ECM components (procollagens and nidogen) and whole-chain complement C3 (Fig. 5).
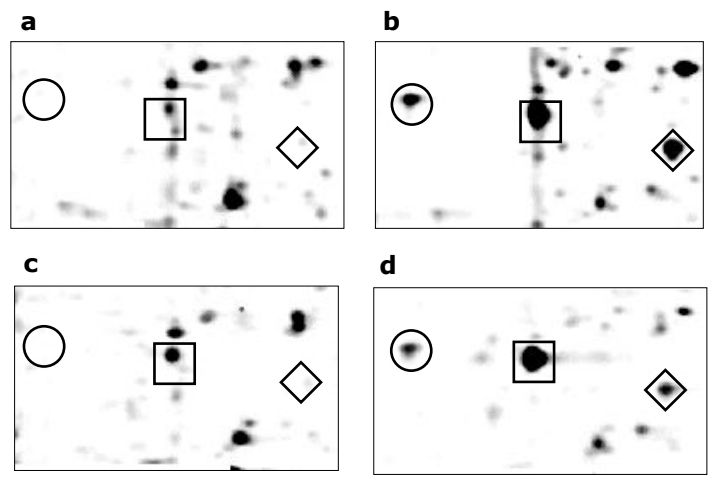

d

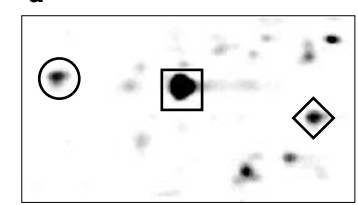

Fig. 4 Collagen C peptides as measured by $2 \mathrm{D}$ gel analysis in (a) basal, (b) high glucose, (c) high insulin and (d) high insulin high glucose conditions. A section of one representative $2 \mathrm{D}$ gel image per condition is shown. Circles, collagen I alpha $1 \mathrm{C}$ peptide; squares, collagen III alpha 1 C-peptide; diamonds, collagen I alpha $2 \mathrm{C}$-peptide

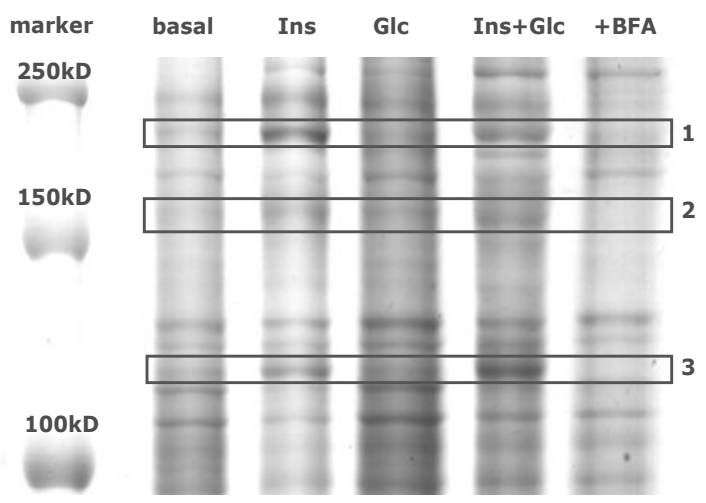

Fig. 5 Differentially expressed high-molecularweight proteins as measured by $1 \mathrm{D}$ gel analysis. One representative image is shown. A sample treated with brefeldin A (+BFA) was used to verify secretion. Band 1: procollagen I alpha $1+$ procollagen III alpha 1; band 2: nidogen+procollagen I alpha 2+collagen VI alpha 2; band 3: complement $\mathrm{C} 3$

The combined secretion profiles showed that insulin increases the secretion and processing of ECM components, such as collagen type I, III, V, VI and nidogen. The upregulation of ECM processing is in line with the increased secretion of processing enzymes and their regulators, such as matrix metalloproteinase 2, metalloproteinase inhibitor 2 and procollagen C-endopeptidase enhancer protein (Table 2). The secretion of most of the detected adipokines, such as complement $\mathrm{C} 3$, adipsin, secreted acidic 
cysteinerich protein (SPARC), and pigment epithelium-derived factor, was stimulated by insulin. The downregulated secretory spots (Table 2) were all from intracellular proteins [10], except adiponectin and galectin-1. Western blotting confirmed that adiponectin was not upregulated by insulin, but this technique also failed to show any significant downregulation (data not shown).

\section{Comparison of insulin effect on transcriptome and proteome of secretory genes} Discriminant principal component analysis is a powerful tool for illustrating the general effect of different treatments. Discriminant principal component analysis of the 2D secreted protein profile confirmed that, compared with glucose alone, insulin generated a clear shift of the secreted protein profile (Fig. 6a). In contrast, the transcription profile of the 36 corresponding genes (nascent polypeptide associated complex alpha polypeptide gene was not included due to its low expression) was hardly affected (Fig. 6b).

The discrepancy between the effect of insulin at the secreted protein level and the mRNA level as observed by discriminant principal component analysis was verified by zooming in on individual proteins/genes (Table 2). Of the 37 genes, 29 were changed by insulin treatment at the secreted protein level. However, only four of them (superoxide dismutase 3 extracellular, macrophage migration inhibitory factor, procollagen type $\mathrm{V}$ alpha 1 and Pcolce) showed a comparable regulation at mRNA level, while the others were not regulated at the transcriptional level.

The strong increase of collagen C-peptides indicated considerable regulation at the protein processing level. In this respect, we found two interesting genes. Prolyl 4hydroxylase catalyses the first post-translational modification (PTM) of collagen, resulting in the 4-hydroxylation of a number of proline residues [15]. Active prolyl 4hydroxylase is a tetramer composed of two pairs of non-identical subunits $(\alpha 2 \beta 2)$. The concentration of alpha-subunit limits the rate of formation of active enzyme [16]. Microarray data, confirmed by Q-PCR, showed that the expression of P4ha1 was significantly upregulated by insulin at both low and high glucose levels (Fig. 2). Glucose itself had no effect on this gene, indicating that this upregulation is glucoseindependent and insulin-specific. Cleavage of $\mathrm{N}$ - and C-peptides is also an important step in fibrillar collagen maturation. The C-endopeptidase enhancer protein (PCOLCE) binds and drives the enzymatic cleavage of type I procollagen [17]. Although the Cendopeptidase (Bmp1) was not changed, the upregulation of Pcolce (Fig. 2) could lead to an increase in proteinase activity and thus contribute significantly to the increased amount of C-peptides in extracellular medium. 
Table 2 Expression of secreted proteins regulated by insulin

\begin{tabular}{|c|c|c|c|c|c|c|c|c|c|}
\hline \multirow{3}{*}{ Protein description } & \multicolumn{4}{|c|}{ Protein secretion level } & \multirow{3}{*}{ Gene } & \multicolumn{4}{|c|}{ mRNA level } \\
\hline & \multicolumn{2}{|c|}{ Ins/Basal } & \multicolumn{2}{|c|}{$\mathrm{Ins}+\mathrm{Glc} / \mathrm{Glc}$} & & \multicolumn{2}{|c|}{ Ins/Basal } & \multicolumn{2}{|c|}{ Ins + Glc/Glc } \\
\hline & $\begin{array}{l}\text { Over } \\
\text {-all }\end{array}$ & $\begin{array}{c}\text { Max } \\
\text { FC }\end{array}$ & $\begin{array}{c}\text { Over } \\
\text {-all }\end{array}$ & Max FC & & $\mathrm{FC}$ & $p$ & FC & $p$ \\
\hline \multicolumn{10}{|l|}{ Down-regulated proteins } \\
\hline Vimentin fragment & - & -4.6 & - & -13.9 & Vim & 1.17 & 0.016 & 1.11 & 0.187 \\
\hline Beta actin fragment & - & -7.6 & - & -6.8 & Actb & -1.12 & 0.077 & 1.20 & 0.028 \\
\hline Cofilin, non-muscle isoform & - & -1.9 & \pm & -1.6 & $C f l 1$ & 1.03 & 0.597 & 1.24 & 0.032 \\
\hline Gesolin fragment & \pm & -1.5 & - & 3.9 & Gsn & 1.10 & 0.236 & 1.11 & 0.115 \\
\hline Adiponectin & - & -2.1 & \pm & -1.5 & $A c d c$ & -1.12 & 0.320 & -1.03 & 0.852 \\
\hline ATP synthase D chain, mitochondrial & - & -2.1 & - & -2.9 & Atp $5 h$ & -1.24 & 0.861 & 1.03 & 0.744 \\
\hline Galectin-1 & - & -1.9 & - & -2.9 & Lgals1 & -1.03 & 0.937 & 1.01 & 0.881 \\
\hline Peroxiredoxin 1 & - & -8.5 & - & -6.6 & $\operatorname{Prdxl}$ & 1.09 & 0.241 & 1.03 & 0.801 \\
\hline Prohibitin & - & -4.0 & - & -5.0 & $P h b$ & -1.07 & 0.392 & 1.08 & 0.437 \\
\hline \multicolumn{10}{|l|}{ Up-regulated proteins } \\
\hline $\begin{array}{l}\text { Collagen I alpha } 1 \text { fragment and C- } \\
\text { terminal peptide }\end{array}$ & + & 31.9 & + & 51.0 & Collal & 1.11 & 0.442 & 1.23 & 0.160 \\
\hline $\begin{array}{l}\text { Collagen I alpha } 2 \text { fragment and C- } \\
\text { terminal peptide }\end{array}$ & + & 14.7 & + & 14.2 & Colla2 & 1.05 & 0.596 & 1.20 & 0.132 \\
\hline $\begin{array}{l}\text { Collagen III alpha } 1 \text { fragment and C- } \\
\text { terminal peptide }\end{array}$ & + & 3.4 & + & 7.0 & Col3al & 1.17 & 0.170 & 1.16 & 0.134 \\
\hline Adipsin & + & 6.0 & + & 3.6 & $A d n$ & -1.20 & 0.204 & -1.11 & 0.397 \\
\hline Collagen V alpha 1 fragment & + & 3.5 & + & 4.8 & Col5al & 1.11 & 0.290 & 1.32 & 0.018 \\
\hline Matrix metalloproteinase-2 & + & 11.7 & \pm & 2.3 & Mmp2 & 1.17 & 0.502 & 1.31 & 0.102 \\
\hline $\begin{array}{l}\text { Procollagen C-endopeptidase enhancer } \\
\text { protein }\end{array}$ & + & 4.2 & + & 7.3 & Pcolce & 1.22 & 0.082 & 1.36 & 0.017 \\
\hline $\begin{array}{l}\text { Pigment epithelium-derived factor } \\
\text { fragment }\end{array}$ & + & 3.2 & + & 1.9 & Serpinf1 & 1.19 & 0.334 & 1.14 & 0.400 \\
\hline $\begin{array}{l}\text { Heterogeneous nuclear } \\
\text { 1ribonucleoprotein A2/B1 }\end{array}$ & \pm & 1.2 & + & $\propto$ & Hnrpa $2 b 1$ & 1.02 & 0.928 & 1.00 & 0.964 \\
\hline superoxide dismutase 3 , extracellular & \pm & -1.1 & + & 2.2 & Sod3 & 1.07 & 0.473 & 1.38 & 0.040 \\
\hline secreted acidic cysteine rich glycoprotein & + & 7.0 & + & 4.2 & Sparc & 1.03 & 0.623 & 1.18 & 0.076 \\
\hline Metalloproteinase inhibitor 2 & \pm & -1.1 & + & $\propto$ & Timp2 & -1.04 & 0.825 & 1.23 & 0.065 \\
\hline \multicolumn{10}{|l|}{ Possible down-regulated proteins } \\
\hline \multirow{2}{*}{$\begin{array}{l}\text { Annexin A5, Coatomer protein subunit } \\
\text { epsilon (mixed with collage III alpha } 1 \\
\text { C-peptide) }\end{array}$} & - & -3.1 & - & -4.0 & Anxa5 & 1.02 & 0.813 & 1.04 & 0.893 \\
\hline & & & & & Cope & 1.14 & 0.180 & 1.11 & 0.362 \\
\hline \multicolumn{10}{|l|}{ Possible up-regulated proteins } \\
\hline \multirow{2}{*}{$\begin{array}{l}\text { Protein-lysine 6-oxidase, alpha enolase } \\
\text { fragment (mixed with collagen I alpha 2) }\end{array}$} & + & $\propto$ & + & $\propto$ & Lox & 1.07 & 0.763 & -1.04 & 0.787 \\
\hline & + & $\propto$ & + & $\propto$ & Enol & 1.20 & 0.079 & 1.21 & 0.157 \\
\hline \multirow{2}{*}{$\begin{array}{l}\text { Macrophage migration inhibitory factor } \\
\text { (mixed with beta- } 2 \text { microglobulin) }\end{array}$} & + & 3.3 & + & 2.7 & Mif & 1.18 & 0.106 & 1.35 & 0.025 \\
\hline & & & & & $B 2 m$ & -1.01 & 0.902 & 1.02 & 0.879 \\
\hline $\begin{array}{l}\text { Nascent polypeptide associated complex } \\
\text { alpha (mixed with collagen V fragment) }\end{array}$ & + & 3.5 & + & 4.8 & $\mathrm{Naca}$ & \multicolumn{4}{|c|}{ undetectable signal on array } \\
\hline Nidogen (mixed with collagen I and VI) & + & (1D) & + & (1D) & Nid1 & 1.04 & 0.529 & 1.09 & 0.293 \\
\hline \multicolumn{10}{|l|}{ Dual regulated proteins } \\
\hline \multirow[t]{2}{*}{ Complement $\mathrm{C} 3$ beta chain } & + & 3.7 & + & 4.0 & $C 3$ & 1.10 & 0.191 & 1.13 & 0.223 \\
\hline & - & -2.3 & - & -7.2 & & & & & \\
\hline
\end{tabular}

Protein secretion levels were measured by $2 \mathrm{D}$ gel analysis $(n=3)$ or by $1 \mathrm{D}$ analysis (1D) when indicated. When more than one spot had the same protein identification, the total signal of all spots was used for comparison to show the overall change (+: increased, \pm : no change, -: decreased) and the fold change of the spot with the maximum change is given (Max FC). mRNA levels were measured by microarray analysis $(n=5)$. FC, fold change; $\propto$, spot appeared only in condition with insulin. $p$ values are for t-test. 

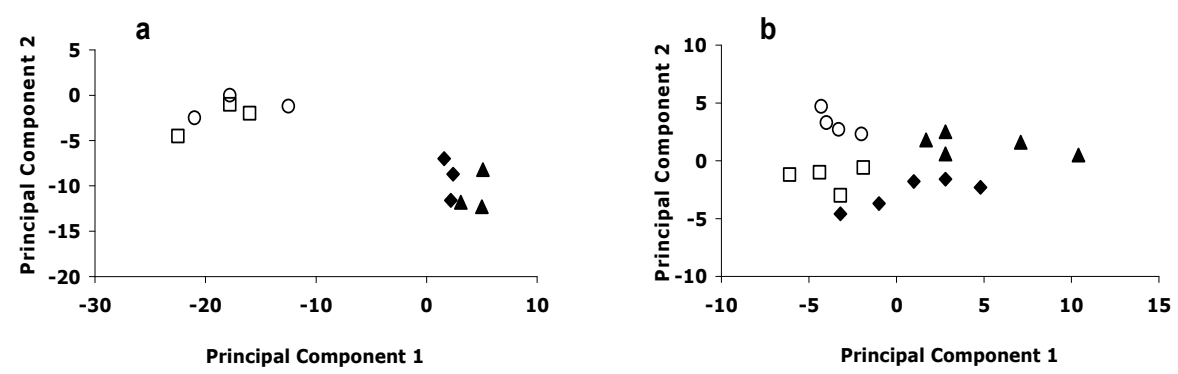

Fig. 6 Discriminant principle component analysis (a) of secreted proteins on the secretion pattern by $2 \mathrm{D}$ gel analysis, and (b) of matched mRNAs on the expression pattern by microarray analysis. One symbol represents one sample profile in the groups of basal $(\bullet)$, insulin $(\square)$, glucose $(\boldsymbol{\Delta})$ or insulin+glucose (०)

\section{Discussion}

We used transcriptomics and proteomics to reveal the effects of insulin on adipocyte secretion. From a proteomics view, insulin had a significant impact on protein secretion. However, transcription is not the major regulation point for these secreted proteins. A discrepancy between mRNA and protein levels has been observed in other studies [18, 19]. In addition to technical differences, the proposed molecular explanations include polysome activation on mRNA, alternative mRNA splicing, protein turnover, specific proteolytic processing and PTMs [20]. Further, the discrepancy between transcript and protein level largely depends on the nature of the proteins studied. Maturation of the secreted proteins involves significant PTMs. For example, glycosylation and signal peptide cleavage are common events for these proteins. A secreted protein undergoes synthesis, modification, and transport before it can be located to its destined extracellular space. Therefore, it is reasonable to expect a low correlation between its mRNA and secreted protein level.

Here, we go further and propose a biological role for this discrepancy in the action of insulin. Insulin is a very potent hormone that is precisely regulated both spatially and temporally [21]. A highly effective means of regulating the activity of target proteins involved in insulin signalling pathways is phosphorylation, one form of PTM. Likewise, PTM can also be used to efficiently promote the secretion of proteins, as an alternative to upregulation of their transcription. On the basis of our findings, insulin promotes collagen protein secretion via the transcriptional upregulation of enzymes involved in PTMs. Via processing enzymes, this regulation can evoke a highly amplified effect. For example PCOLCE, which was up-regulated in this study, can enhance the activity of procollagen Cendopeptidase up to 20 -fold [17]. 
Besides an effect on collagens, increased processing and other PTMs might also explain effects on other secreted proteins, such as adipsin, SPARC and complement C3, which are highly upregulated by insulin at the secretion level, but not at the mRNA level. Alternatively, this could be explained by a general upregulation of exocytosis.

Using the 2D gel system to study adipocyte secretion in mouse 3T3-L1 cells has several advantages and limitations, as discussed previously [10]. Only part of the secretory proteome is visualised. For instance, we were not able to cover all known adipocytesecreted proteins to address their response to insulin and determine the relationship between their mRNA and secretion levels. Further, the change of protein quantity based on a single spot may be underestimated if a protein is present in several isoforms and thus as several spots on the gel, or overestimated if one gel spot contains more than one protein. Therefore we took all the spots with the same identification into account and provide information on mixed spots in Table 2. One major advantage of 2D gel analysis is that it is useful for visualising protein modifications. The different isoforms and modifications can be separated on the basis of their different isoelectric points and mol. wt. The importance of processing and secondary modification as the effect of insulin is illustrated by the $2 \mathrm{D}$ analysis of the $\mathrm{C}$-peptides of collagens. Another example is that the beta chain of complement $\mathrm{C} 3$ had three spots on the gel [10]. Two spots were upregulated, as was the $\mathrm{C} 3$ complete chain on 1D gel, and one spot was downregulated by insulin, indicating different modifications. Detailed information about the modifications may provide more insight into the exact effect of insulin on the expression and function of these proteins.

Insulin promotes cell survival and anti-apoptosis [22, 23]. Numerous studies have shown that cell survival and death strongly depend on cell adhesion and the ECM [24, 25]. Our previous work showed that ECM components represent a major part of the proteins secreted from 3T3-L1 adipocytes in vitro [10]. We propose that the upregulation of secretion of ECM components, together with the increased gene expression of adhesion molecules (Table 1) by insulin, contributes to a strengthened survival of in vitro cultured adipocytes. Since in vivo adipocytes are intensively supported by the basement membrane [26], insulin may similarly affect adipocyte survival in vivo.

Apart from adiponectin and galectin, the downregulated proteins in the medium are not genuine secreted proteins. As a reflection of secreted proteinase activity, their presence in the medium may be caused by leakage and shedding [10]. In view of the improved cell survival, it is not surprising to see a decrease of leaked cellular proteins. The difference from other genuine secreted proteins implies that secretion of adiponectin and galectin 1 is regulated by insulin in a different way. This may be consistent with the finding that adiponectin and collagen VI alpha 3 are in two distinct exocytosis compartments [7].

Here, we report for the first time that Sulf2 expression is significantly upregulated by insulin in 3T3-L1 adipocytes in vitro. Sulf2 belongs to the family of extracellular endosulfatases that are able to remodel the 6-O sulfation state of cell surface heparan sulfate proteoglycans (HSPG). Again, its regulation shows that transcription of PTM enzyme genes is a target of insulin in adipocytes. The human SULF2 (KIAA1247) gene 
is located in a type 2 diabetes susceptibility region on human chromosome 20 [27]. HSPG has been implicated in diverse physiological processes [28-31] by binding ligands for which the specific structure and/or negative charge of the heparan sulfate chain is instrumental [32]. It has already been reported that de-sulfation of HSPG accounts for altered function. For example, avian QSULF1, a family member of Sulf2, inhibited angiogenesis in vitro [33]. Analogously, desulfation triggered by insulin via Sulf2 may induce functional changes in adipocytes. Interestingly, reduced amounts and an altered function of HSPG have been extensively reported in patients with type 2 and also type 1 diabetes $[34,35]$. The decrease of HSPG and their sulfation in diabetes may be due to a decrease of N-deacetylase [36], possibly induced by a high glucose level [37]. However, others have shown that high glucose only diminished the level of HSPG without significant changes in N-deacetylase and sulfation (especially N-sulfation) in cultured 3T3-L1 adipocytes [38]. Besides glucose, insulin has also been considered to underlie alteration of HSPG. The 35S labelled HSPG from liver were lower in obese and insulin-resistant Zucker rats than in their unaffected littermates [39]. Our results suggest that besides glucose, insulin might independently induce a pattern change in HSPG in cultured adipocytes. Immunocytochemical analysis with the antibody 10E4 (Seikagaku, Tokyo, Japan) has been used to assay the 6-O de-sulfation by transfected Qsulf1 in 3T3-L1 fibroblasts [40]. Using this antibody, we failed to detect a significant decrease of HSPG sulfation in 3T3-L1 mature adipocytes after treatment with insulin (data not shown). However, the 10E4 antibody may not be able to properly recognise 6O sulfation [41].

\section{Conclusion}

We used a combined transcriptomic and proteomic approach to study the effect of insulin on mature 3T3-L1 adipocytes focusing on secreted proteins. Interestingly, we observed that insulin has a large effect on secretion but not on transcription of secreted protein genes. This discrepancy may be partly explained by the transcriptional upregulation of processing protein genes. It reveals that PTM is induced by insulin not only in signal transduction, but also in the regulation of secretion. Determination of quantity and activity of the PTM-enzymes will further support this hypothesis. Our study is one of the first to use transcriptomics and proteomics, and clearly demonstrates the added value of a combined genomics approach to the study of biological mechanisms.

Acknowledgements We thank our colleagues in the Functional Genomics Group and the Food Bioactives Group for technical support and helpful discussions. We also thank J. Broers and F. Houben (Department of Molecular Cell Biology) for help with immunocytochemistry. This study was financed by the Centre for Human Nutrigenomics in the Netherlands. 


\section{References}

1. Kahn BB, Flier JS (2000) Obesity and insulin resistance. J Clin Invest 106:473-481

2. Fasshauer M, Paschke R (2003) Regulation of adipocytokines and insulin resistance. Diabetologia 46:1594-1603

3. Lafontan M (2005) Fat cells: afferent and efferent messages define new approaches to treat obesity. Annu Rev Pharmacol Toxicol 45:119-146

4. Faraj M, Lu HL, Cianflone K (2004) Diabetes, lipids, and adipocyte secretagogues. Biochem Cell Biol $82: 170-190$

5. Summers SA, Whiteman EL, Birnbaum MJ (2000) Insulin signaling in the adipocyte. Int J Obes Relat Metab Disord 24 (Suppl 4):S67-S70 Diabetologia (2006) 49:2453-2462 2461

6. Lin Y, Berg AH, Iyengar P et al (2005) The hyperglycemia induced inflammatory response in adipocytes: the role of reactive oxygen species. J Biol Chem 280:4617-4626

7. Bogan JS, Lodish HF (1999) Two compartments for insulin stimulated exocytosis in 3T3-L1 adipocytes defined by endogenous ACRP30 and GLUT4. J Cell Biol 146:609-620

8. Millar CA, Meerloo T, Martin S et al (2000) Adipsin and the glucose transporter GLUT4 traffic to the cell surface via independent pathways in adipocytes. Traffic 1:141-151

9. Chen X, Cushman SW, Pannell LK, Hess S (2005) Quantitative proteomic analysis of the secretory proteins from rat adipose cells using a 2D liquid chromatography-MS/MS approach. J Proteome Res 4:570-577

10. Wang P, Mariman E, Keijer J et al (2004) Profiling of the secreted proteins during 3T3-L1 adipocyte differentiation leads to the identification of novel adipokines. Cell Mol Life Sci 61:2405-2417

11. Pellis L, Franssen-van Hal NL, Burema J, Keijer J (2003) The intraclass correlation coefficient applied for evaluation of data correction, labeling methods, and rectal biopsy sampling in DNA microarray experiments. Physiol Genomics 16:99-106

12. Van Der Meer-Van Kraaij C, Van Lieshout EM, Kramer E, Van Der Meer R, Keijer J (2003) Mucosal pentraxin (Mptx), a novel rat gene 10-fold down-regulated in colon by dietary heme. FASEB J 17:12771285

13. Bouwman F, Renes J, Mariman E (2004) A combination of protein profiling and isotopomer analysis using matrix-assisted laser desorption/ionization-time of flight mass spectrometry reveals an active metabolism of the extracellular matrix of 3T3- L1 adipocytes. Proteomics 4:3855-3863

14. Ueki K, Fruman DA, Yballe CM et al (2003) Positive and negative roles of p85 alpha and p85 beta regulatory subunits of phosphoinositide 3-kinase in insulin signaling. J Biol Chem 278:48453-48466

15. Alberts B, Johnson A, Lewis J, Raff M, Roberts K, Walter P (2002) Cell junctions, cell adhesion, and the extracellular matrix. In: Gibbs S (ed) Molecular biology of the cell. Garland, New York, pp 1065-1126

16. Kivirikko KI, Helaakoski T, Tasanen K et al (1990) Molecular biology of prolyl 4-hydroxylase. Ann N Y Acad Sci 580: 132-142

17. Ricard-Blum S, Bernocco S, Font B et al (2002) Interaction properties of the procollagen C-proteinase enhancer protein shed light on the mechanism of stimulation of BMP-1. J Biol Chem 277:33864-33869

18. Chen G, Gharib TG, Huang CC et al (2002) Discordant protein and mRNA expression in lung adenocarcinomas. Mol Cell Proteomics 1:304-313

19. Griffin TJ, Gygi SP, Ideker T et al (2002) Complementary profiling of gene expression at the transcriptome and proteome levels in Saccharomyces cerevisiae. Mol Cell Proteomics 1: 323-333

20. Hegde PS, White IR, Debouck C (2003) Interplay of transcriptomics and proteomics. Curr Opin Biotechnol 14:647-651

21. Saltiel AR, Pessin JE (2002) Insulin signaling pathways in time and space. Trends Cell Biol 12:65-71

22. Kido Y, Nakae J, Accili D (2001) Clinical review 125: the insulin receptor and its cellular targets. J Clin Endocrinol Metab 86: 972-979

23. Barthel A, Schmoll D, Unterman TG (2005) FoxO proteins in insulin action and metabolism. Trends Endocrinol Metab 16:183-189

24. Santini MT, Rainaldi G, Indovina PL (2000) Apoptosis, cell adhesion and the extracellular matrix in the three-dimensional growth of multicellular tumor spheroids. Crit Rev Oncol Hematol 36:75-87

25. Farrelly N, Lee YJ, Oliver J, Dive C, Streuli CH (1999) Extracellular matrix regulates apoptosis in mammary epithelium through a control on insulin signaling. J Cell Biol 144:1337-1348

26. Pierleoni C, Verdenelli F, Castellucci M, Cinti S (1998) Fibronectins and basal lamina molecules expression in human subcutaneous white adipose tissue. Eur J Histochem 42:183-188

27. Fossey SC, Mychaleckyj JC, Pendleton JK et al (2001) A highresolution 6.0-megabase transcript map of the type 2 diabetes susceptibility region on human chromosome 20. Genomics 76:45-57

28. BernfieldM, GotteM, Park PWet al (1999) Functions of cell surface heparan sulfate proteoglycans. Annu Rev Biochem 68:729-777

29. Iozzo RV (2001) Heparan sulfate proteoglycans: intricate molecules with intriguing functions. J Clin Invest 108:165-167 
30. Wilsie LC, Chanchani S, Navaratna D, Orlando RA (2005) Cell surface heparan sulfate proteoglycans contribute to intracellular lipid accumulation in adipocytes. Lipids Health Dis 4:2

31. Mahley RW, Ji ZS (1999) Remnant lipoprotein metabolism: key pathways involving cell-surface heparan sulfate proteoglycans and apolipoprotein E. J Lipid Res 40:1-16

32. Nakato H, Kimata K (2002) Heparan sulfate fine structure and specificity of proteoglycan functions. Biochim Biophys Acta 1573:312-318

33. Wang S, Ai X, Freeman SD et al (2004) QSulf1, a heparan sulfate 6-O-endosulfatase, inhibits fibroblast growth factor signaling in mesoderm induction and angiogenesis. Proc Natl Acad Sci USA 101:48334838

34. Kozma EM, Olczyk K, Glowacki A et al (1996) Glycosaminoglycans of human serum and their alterations in diabetes mellitus. Acta Biochim Pol 43:567-574

35. Conde-Knape K (2001) Heparan sulfate proteoglycans in experimental models of diabetes: a role for perlecan in diabetes complications. Diabetes Metab Res Rev 17:412-421

36. Kjellen L, Bielefeld D, Hook M (1983) Reduced sulfation of liver heparan sulfate in experimentally diabetic rats. Diabetes 32: 337-342

37. Kofoed-Enevoldsen A, Noonan D, Deckert T (1993) Diabetes mellitus induced inhibition of glucosaminyl N-deacetylase: effect of short-term blood glucose control in diabetic rats. Diabetologia 36:310-315

38. Parthasarathy N, Gotow LF, Bottoms JD et al (2000) Influence of glucose on production and N-sulfation of heparan sulfate in cultured adipocyte cells. Mol Cell Biochem 213:1-9

39. Olsson U, Egnell AC, Lee MR et al (2001) Changes in matrix proteoglycans induced by insulin and fatty acids in hepatic cells may contribute to dyslipidemia of insulin resistance. Diabetes 50:2126-2132

40. Ai X, Do AT, Lozynska O, Kusche-Gullberg M, Lindahl U, Emerson CP Jr (2003) QSulf1 remodels the 6$\mathrm{O}$ sulfation states of cell surface heparan sulfate proteoglycans to promote Wnt signaling. J Cell Biol $162: 341-351$

41. van den Born J, Salmivirta K, Henttinen T et al (2005) Novel heparan sulfate structures revealed by monoclonal antibodies. J Biol Chem 280:20516-20523 2462 Diabetologia (2006) 49:2453-2462 
Chapter 3. Insulin modulates adipocyte secretion 


\section{Absence of an adipogenic effect of rosiglitazone on mature 3T3-L1 adipocytes: increase of lipid catabolism and reduction of adipokine expression}

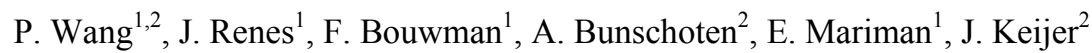

${ }^{1}$ Functional Genomics Group, The Nutrition and Toxicology Research Institute Maastricht (NUTRIM), Department of Human Biology, Maastricht University, Maastricht, the Netherlands. ${ }^{2}$ Food Bioactives Group, RIKILT-Institute of Food Safety, Wageningen, the Netherlands.

Diabetologia (2007) In press

DOI 10.1007/s00125-006-0565-0 


\begin{abstract}
Aims/hypothesis The thiazolidinedione (TZD) rosiglitazone is a peroxisome proliferatoractivated receptor- $\gamma$ agonist that induces adipocyte differentiation and, hence, lipid accumulation. This is in apparent contrast to the long-term anti-diabetic, insulinsensitising effect of rosiglitazone. We tested whether the action of rosiglitazone involves specific effects on mature adipocytes, which are different from those on preadipocytes.

Methods Differentiated mature 3T3-L1 adipocytes were used as an in vitro model. Transcriptomics, proteomics and assays of metabolism were applied to assess the effect of rosiglitazone in different insulin and glucose conditions.

Results Rosiglitazone does not induce an increase, but rather a decrease of the lipid content of mature adipocytes. Analysis of transcriptome data, confirmed by quantitative RT-PCR and measurements of lipolysis, indicates that an altered energy metabolism may underlie this change. The pathway analysis shows a consistent picture dominated by lipid catabolism. In addition, we confirmed at both mRNA level and protein level that rosiglitazone represses adipokine expression, except adiponectin and apolipoprotein E gene. Moreover, transcriptome changes indicate that a general repression of genes encoding secreted proteins occurs.

Conclusions/interpretation Our findings suggest that the change of adiposity as seen in vivo reflects a shift in balance between the different effects of TZDs on preadipocytes and on mature adipocytes, while the changes in circulating adipokine levels primarily result from an effect on mature adipocytes.
\end{abstract}

\title{
Keywords
}

Adipose tissue, adipokine, energy metabolism, lipogenesis, lipolysis, mature adipocytes, microarray, secretion, thiazolidinediones

\section{Abbreviations}

ADFP: adipocyte differentiation-related protein; APOE: apolipoprotein E; CAV1: caveolin 1; 1D: one-dimensional; 2D: two-dimensional; FASN: fatty acid synthase ; IG: high glucose and insulin condition; PPAR: peroxisome proliferator-activated receptor; PPARG: peroxisome proliferator-activated receptor gamma; PPRE: PPAR-responsive element; Q-PCR: quantitative real time RT- PCR; Rosi: rosiglitazone with low insulin and glucose condition; RosilG: rosiglitazone with high insulin and glucose condition; Rps15 : ribosomal protein S15; SCD1: stearoyl-Coenzyme A desaturase 1; TCA cycle: citric acid cycle; TZD: thiazolidinedione ; UCP2: uncoupling protein 2 


\section{Introduction}

Rosiglitazone (BRL-49653), a thiazolidinedione (TZD) drug, is used against type 2 diabetes mellitus [1]. It has been proposed that the glucose-lowering action of TZDs is mainly mediated by activating peroxisome proliferator-activated receptor (PPAR)- $\gamma$ (PPARG) [2, 3]. PPARG is most abundantly produced in adipose tissue, suggesting that this is the primary site of action of TZDs [4]. Proposed mechanisms underlying the adipocyte-mediated anti-diabetic action of TZDs are the trapping of fatty acids inside adipocytes and away from muscle, the so-called 'fatty acid steal' hypothesis and the altering adipokine release [1].

PPARG is a critical transcription factor in adipogenesis [5]. Its expression increases strongly during adipocyte differentiation [6]. By activating PPARG, rosiglitazone promotes adipocyte differentiation in vitro $[7,8]$. An increase in the number of small adipocytes and fat mass by TZDs in both animal models and human subjects, suggests that adipocyte differentiation also occurs in vivo $[9,10]$. Compared with preadipocytes, adipocytes have a much higher capacity for fatty acid uptake and lipid storage and are potentially more insulin-sensitive due to higher numbers of glucose transporters and insulin receptors [6]. By increasing the number of adipocytes, TZDs can lower circulating NEFA and improve lipid exposure of peripheral tissues, thus improving whole-body insulin sensitivity [1].

This hypothesis is clearly attractive, but other effects of TZDs may occur. It has been pointed out that the increased number of small adipocytes caused by TZD treatment is not only a result of the appearance of new adipocytes, but also due to the shrinkage and/or disappearance of existing mature adipocytes [10]. TZD-induced body weight gain in vivo is used as a marker of increased adiposity. However, there is evidence that this may also be due to fluid retention [11]. In fact, the fat mass may be unaffected or even decreased. In $o b / o b$ mouse, whole body weight was increased, but the fat pad weight was not changed after rosiglitazone treatment [12]. In type 2 diabetes patients, the visceral fat area was found to be decreased [13]. 'Fatty acid steal' therefore is not just a matter of increased lipid storage.

The maturation of adipocytes is positively correlated with the expression of adipokines. Several of these profoundly influence insulin sensitivity and glucose metabolism, e.g leptin, adiponectin and resistin [14]. However, it has been observed that TZDs decrease the circulating level of individual adipokines such as leptin [15], resistin [16] and plasminogen activator inhibitor-1 [17], and also of cytokines [18]. A decreased production of these adipokines by TZDs seems to conflict with the adipogenic properties of these drugs.

The above discrepancy could be due to different effects on preadipocytes and mature adipocytes in adipose tissue. It is clear that TZDs stimulate preadipocytes into the process of differentiation. However, their effect on mature adipocytes is less clear. In vivo studies do not allow us to distinguish between the effects on these two cell types. Therefore, to study the effects of TZDs on mature adipocytes, we used in vitro differentiated mature 3T3-L1 adipocytes. In addition to the assessment of lipid accumulation and adipokine secretion, we used transcriptomics to obtain insight into the 
effects of rosiglitazone. Although high insulin and high glucose levels mimic the situation in vivo when rosiglitazone is administered, we also included low insulin and low glucose levels for comparison purposes.

\section{Materials and methods}

Cell culture and sample preparation Murine 3T3-L1 fibroblasts (CL-173; American Type Culture Collection, Manassas, VA, US) were cultured and differentiated to adipocytes in vitro as described [19]. On day 8, differentiated cells, grown in DMEM/F12 (1:1) supplemented with 10\% fetal calf serum (Perbio Science, Erembodegem, Belgium), were treated with $0.5 \mu \mathrm{mol} / 1$ rosiglitazone maleate (GlaxoSmithKline, Worthing, UK) with low (4.5 mmol/l) glucose and (fetal calf serum level) insulin (Rosi), or with high (15.75 mmol/l) glucose and $1 \mu \mathrm{mol} / 1$ insulin (RosiIG). In parallel, control cells were cultured in the same medium with low (basal) or high glucose and insulin (IG). Each condition was created in quadruplicate. On day 10, two replications were collected separately for total RNA isolation using Trizol as described [19]. Cells of the other two replications were washed and incubated with the corresponding serum-free medium, supplemented with $2.2 \mathrm{mg} / \mathrm{l}$ transferrin and $10.6 \mathrm{nmol} / 1$ sodium selenite for 6 hours. The number of cells was counted and culture medium proteins were collected as described [20]. The duplicated protein samples were pooled for later analysis. Three independent experiments were performed.

Oil-red O staining An optimised oil-red O staining method [21] was adapted for 3T3L1 adipocytes cultured in a 6-well plate. We added an additional quick wash with $70 \%$ ethanol after fixing and washing with water. After staining and washing, the neutral lipid-bound pigment was dissolved in DMSO and absorbance at $540 \mathrm{~nm}$ was measured. The staining for 3T3-L1 preadipocytes was used as background to correct for unspecific binding. The obtained absorbance values were further corrected for cell numbers measured in replicated wells. Five independent experiments were performed in duplicate, but in the first two experiments Basal and Rosi conditions were not measured.

Glycerol assay The culture media of cells that had been treated for $48 \mathrm{~h}$ were collected per condition, frozen in liquid $\mathrm{N}_{2}$, then stored at $-80{ }^{\circ} \mathrm{C}$ until analysis. The concentration of glycerol in the medium was measured by a quantitative enzymatic assay kit (Sigma, Saint Louis, MO, USA), according to the manufacturer's instruction. The concentrations were corrected for cell numbers measured in replicated wells in parallel.

Microarray The mouse 10K_A oligo set (MWG, Ebersberg, Germany) and additional oligonucleotides of genes encoding secretory proteins and proteins involved in energy metabolism were in-house printed and further annotated as described [19]. Five total RNA samples of three independent experiments per condition were used for hybridisation against reference RNA, also as described [19]. 
Microarray data analysis The data were analysed as described [19]. Briefly, spots with an average intensity, over all arrays, of lower than twofold above average background were removed from further analysis, then the intensities of the remaining 4019 spots were normalised against reference. Fold-change calculations, student $t$ tests and correlation test (Pearson) were performed in Excel (Microsoft). Fold-change equals ratio in the case of increase and equals -1 /ratio in the case of decrease. Cut-off criteria for differential expression was set at fold-change $>1.3$ and $p<0.05$. For genes with replicated spots, the average value of individual spots was used.

Data were further analysed using Ingenuity Pathways Analysis (Ingenuity Systems, www.ingenuity.com). The program recognised 4005 of 4019 spot entries, and thus a total of 3718 genes. Differentially expressed genes that associated with a canonical pathway in the Ingenuity Pathways Knowledge Base were considered for evaluation. The significance of the association between the data set and the canonical pathway was measured in two ways: (1) a ratio of the number of genes from the data set that map to the pathway divided by the total number of genes that map to the canonical pathway is displayed; (2) Fischer's exact test was used to calculate a $p$-value determining the probability that the association between the genes in the dataset and the canonical pathway is explained by chance alone. A pathway with a significance $<0.05$ was taken as significantly regulated.

Quantitative real-time RT-PCR All six total RNA samples per treatment were used for quantitative real-time RT-PCR (Q-PCR) of 22 genes (primer information in supplementary material Table 1). Q-PCR was performed as described [19]. Ribosomal protein S15 (Rps15) mRNA was used as reference.

One-dimensional and two-dimensional gel electrophoresis Protein samples were analysed by one-dimensional (1D) and two-dimensional (2D) gel electrophorosis, corrected for cell numbers, as described [19]. Brefeldin-A-treated adipocyte medium protein sample [20] was loaded on the same 1D gel, to verify protein secretion. Differentially expressed secreted protein bands were excised and identified by matrixassisted laser desorption ionisation-time of flight mass spectrometry [22].

Western blotting The secretion level of adiponectin was analysed by $1 \mathrm{D}$ western blotting as described [20].

\section{Results}

Effect of rosiglitazone on the lipid content of mature adipocytes To assess the effect of rosiglitazone on lipid accumulation in mature adipocytes, we measured the lipid content of differentiated 3T3-L1 adipocytes. Visual inspection by microscopy showed no change in morphology and fat cell percentage in the population of 3T3-L1 adipocytes after 2 days of treatment with RosilG or Rosi $(0.5 \mu \mathrm{mol} / 1$ rosiglitazone at either high or low insulin/glucose levels respectively), as compared with untreated adipocytes. Nevertheless, the lipid content, as detected by oil-red $\mathrm{O}$ staining, was $10 \%$ 
lower $(p<0.001, \mathrm{n}=5)$ in RosilG-treated cells, while no difference was observed in Rositreated cells (Fig. 1).

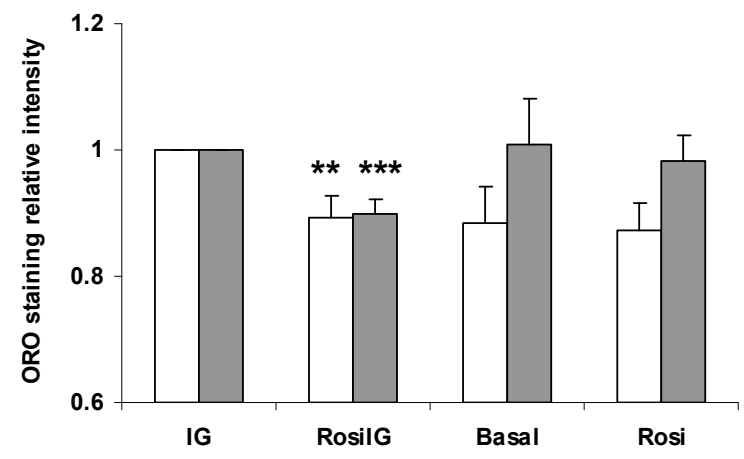

Fig. 1. Oil red O staining (ORO) for lipid content in 3T3-L1 adipocytes. Data are expressed as mean \pm SD. $n=5$ for high glucose and insulin (control condition) (IG) and rosiglitazone with high insulin and glucose condition (RosiIG); $n=3$ for basal and rosiglitazone with low insulin and glucose condition (Rosi). Blank bars: absorbance, relative value; filled bars: absorbance, relative value corrected for cell numbers. ${ }^{* *} p<0.01$ compared with IG condition before cell number correction (t test), ${ }^{* * *} p<0.001$ compared with IG condition after cell number correction (t test).

Effect of rosiglitazone on gene expression To reveal the possible mechanisms for the decreased lipid content of rosiglitazone-treated 3T3-L1 adipocytes, we used DNA microarray to profile the gene expression. The complete analysis set was imported into Ingenuity Pathway Analysis for canonical pathway analysis. The significantly changed pathways were involved in metabolism, but not in signalling, such as PPAR signalling or insulin receptor signalling (Fig. 2). The expression of Pparg itself was downregulated 1.8- and 2.2-fold $(p<0.005)$ by Rosi and RosilG treatment respectively. Notably, pathways related to energy metabolism were among those that were most changed. Taking the high redundancy among these pathways in the Ingenuity database into account, we checked the individual pathways for redundancy. This showed that oxidative phosphorylation, fatty acid metabolism, glycolysis and gluconeogenesis, the pentose phosphate pathway, the citric acid (TCA) cycle, glycerolipid metabolism, glutathione metabolism, steroid (androgen, estrogen and C21 steroids) metabolism and prostaglandin metabolism are independent pathways, while for the others it cannot be ruled out that they were identified as significant just because they contain genes overlapping with other pathways.

For these independently regulated pathways, we determined the direction of change by examining the individual genes in the pathways. The regulation of gene expression of rate-limiting or otherwise representative enzymes is presented in Table 1. High 
insulin/glucose attenuated the effect of rosiglitazone on some genes of complex I and II of the electron transport chain. However, high insulin/glucose treatment itself did not induce a change in the expression of these genes from the basal state. In general, rosiglitazone produced dominant effects, as indicated by the Pearson product moment correlation coefficient of 0.875 for the fold changes of the complete analysis set of Rosi/Basal and RosiIG/IG. The changes in the pathways indicate that rosiglitazone enhanced both energy metabolism at the TCA cycle and oxidative phosphorylation. The generated energy may be dispensed with the help of up-regulated uncoupling protein 2 (Ucp2). Enhanced energy metabolism is mainly supported by up-regulation of the pathways involved in uptake and activation of fatty acids and in beta-oxidation in both mitochondria and peroxisomes. In contrast, de novo fatty acid synthesis was downregulated, as indicated by fatty acid synthase (Fasn) and stearoyl-Coenzyme A desaturase $1(S c d 1)$. The down-regulation of triglyceride synthesis enzymes and upregulation of adipocyte lipase (patatin-like phospholipase domain containing 2) together imply a decreased lipogenesis in mature adipocytes (Table 1).

Accompanying fatty acid catabolism, glycerol activation by glycerol kinase and oxidation by glycerol phosphate dehydrogenase to dihydroxyacetone phosphate were up-regulated, feeding glycolysis and gluconeogenesis. The enzymes catalysing glycolysis/gluconeogenesis were all up-regulated, possibly in favour of gluconeogenesis. In addition, the up-regulation of glycogenin, a gene priming glycogen synthesis, implies an increase of glycogen synthesis.

Most genes in the amino acid metabolism pathways that were regulated also participate in fatty acid metabolism or in glycolysis. Therefore, we did not take amino acid metabolism pathways as independent rosiglitazone-regulated pathways. However, two key enzymes that catalyse the catabolism of leucine (Table 1) were down-regulated. This implies that rosiglitazone saves amino acids from being used as fuel in energy metabolism.

Glutathione metabolism was significantly changed by rosiglitazone treatment. Two glutathione S-transferases that detoxify lipid peroxides, microsomal glutathione Stransferase 3 and glutathione S-transferase A4, were up-regulated, while other glutathione S-transferases were down-regulated by rosiglitazone. This is in line with the up-regulation of fatty acid oxidation by rosiglitazone.

Microsomal glutathione S-transferase 3 is involved not only in glutathione metabolism, but also in eicosanoid metabolism, which is also regulated by rosiglitazone. The expression of genes encoding enzymes involved in prostaglandin metabolism implies that the conversion from prostaglandin $\mathrm{H} 2$ to E2, F2 and D2 may be enhanced, while conversion to I 2 may be reduced.

Cholesterol biosynthesis and steroid hormone metabolism were also affected by rosiglitazone. Expression of some steroid dehydrogenases were up-regulated, while hydroxysteroid 11-beta dehydrogenase 1 was down-regulated (Table 1). The latter has been reported as one of the beneficial effects of TZDs, leading to a decrease in the stress hormone cortisol [23]. 


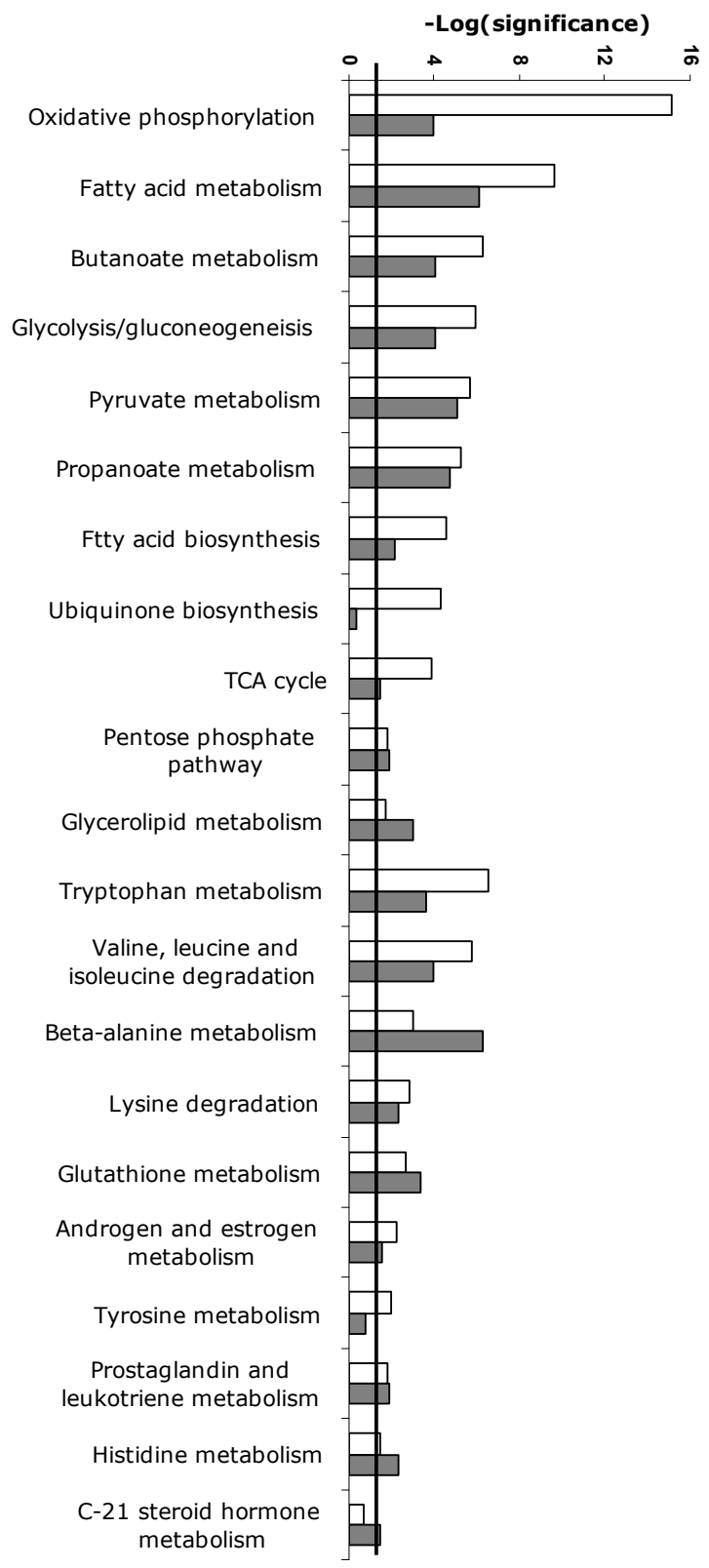

Fig. 2. Regulated canonical pathways by rosiglitazone. Microarray data analysed by Ingenuity Pathway Analysis. Blank bars, with low insulin/glucose; filled bars, with high insulin/glucose. Bold line, threshold. 
Table 1. Key enzymes of metabolism pathways regulated by rosiglitazone.

\begin{tabular}{|c|c|c|c|c|c|c|c|c|}
\hline \multirow[t]{2}{*}{ Pathway } & \multirow[t]{2}{*}{ Change } & \multirow[t]{2}{*}{ Gene } & \multirow[t]{2}{*}{ GeneID } & \multirow[t]{2}{*}{ Name } & \multicolumn{2}{|c|}{ Rosi/Basal } & \multicolumn{2}{|c|}{ RosiIG/IG } \\
\hline & & & & & $\begin{array}{l}\text { Fold - } \\
\text { change }\end{array}$ & $p$ & $\begin{array}{l}\text { Fold- } \\
\text { change }\end{array}$ & $p$ \\
\hline \multirow[t]{2}{*}{ TCA cycle } & \multirow[t]{2}{*}{ Up } & $I d h 3 a$ & 67834 & $\begin{array}{l}\text { Isocitrate dehydrogenase } 3 \text { (NAD+) } \\
\text { alpha }\end{array}$ & 2.53 & 0.000 & 2.55 & 0.000 \\
\hline & & Cs & 12974 & Citrate synthase & 1.95 & 0.000 & 1.47 & 0.000 \\
\hline \multirow{5}{*}{$\begin{array}{l}\text { Oxidative } \\
\text { phosphory- } \\
\text { lation }\end{array}$} & \multirow[t]{5}{*}{ Up } & Ndufa 5 & 68202 & $\begin{array}{l}\text { NADH dehydrogenase (ubiquinone) } 1 \\
\text { alpha subcomplex, } 5\end{array}$ & 1.72 & 0.009 & 1.20 & 0.235 \\
\hline & & Sdhd & 66925 & $\begin{array}{l}\text { Succinate dehydrogenase complex, } \\
\text { subunit D }\end{array}$ & 1.83 & 0.001 & 1.51 & 0.039 \\
\hline & & Uqcrcl & 22273 & $\begin{array}{l}\text { Ubiquinol-cytochrome c reductase core } \\
\text { protein I }\end{array}$ & 1.47 & 0.007 & 1.33 & 0.017 \\
\hline & & Cox7al & 12865 & $\begin{array}{l}\text { Cytochrome c oxidase subunit VIIa } \\
\text { polypeptide } 1\end{array}$ & 1.78 & 0.002 & 1.55 & 0.003 \\
\hline & & Atp $5 h$ & 71679 & $\begin{array}{l}\text { ATP synthase, } \mathrm{H}+\text { transporting, } \\
\text { mitochondrial F0 complex, subunit d }\end{array}$ & 1.71 & 0.006 & 1.49 & 0,005 \\
\hline \multirow{2}{*}{$\begin{array}{l}\text { Fatty acid } \\
\text { transport }\end{array}$} & \multirow[t]{2}{*}{ Up } & $C d 36$ & 12491 & CD36 antigen, & 2.54 & 0.000 & 2.27 & 0.006 \\
\hline & & Fabp4 & 11770 & Fatty acid bind & 1.64 & 0.088 & 1.57 & 0.142 \\
\hline $\begin{array}{l}\text { Fatty acid } \\
\text { activation }\end{array}$ & Up & Acsll & 14081 & $\begin{array}{l}\text { Acyl-CoA synthetase long-chain family } \\
\text { member } 1\end{array}$ & 2.50 & 0.000 & 1.97 & 0.000 \\
\hline \multirow{5}{*}{$\begin{array}{l}\text { Fatty acid beta } \\
\text { oxidation }\end{array}$} & \multirow[t]{5}{*}{ Up } & Crat & 12908 & Carnitine acetyltransferase & 1.45 & 0.006 & 1.47 & 0.007 \\
\hline & & Slc $25 a 20$ & 57279 & $\begin{array}{l}\text { Solute carrier family } 25 \text { (mitochondrial } \\
\text { carnitine/acylcarnitine translocase), } \\
\text { member } 20\end{array}$ & 1.63 & 0.003 & 1.22 & 0.092 \\
\hline & & Acox 1 & 11430 & Acyl-Coenzyme A oxidase 1, palmitoyl & 2.70 & 0.000 & 2.54 & 0.000 \\
\hline & & Acaal & 113868 & $\begin{array}{l}\text { Acetyl-Coenzyme A acyltransferase } 1 \\
\text { (peroxisomal) }\end{array}$ & 1.67 & 0.002 & 1.29 & 0.017 \\
\hline & & Acaa2 & 52538 & $\begin{array}{l}\text { Acetyl-Coenzyme A acyltransferase } 2 \\
\text { (mitochondrial) }\end{array}$ & 2.70 & 0.000 & 1.94 & 0.000 \\
\hline \multirow{2}{*}{$\begin{array}{l}\text { Fatty acid } \\
\text { synthesis }\end{array}$} & \multirow[t]{2}{*}{ Down } & Fasn & 14104 & Fatty acid synthase & -1.52 & 0.000 & -1.55 & 0.001 \\
\hline & & $S c d 1$ & 20249 & Stearoyl-CoA desaturase 1 & -3.65 & 0,000 & -4.31 & 0,000 \\
\hline \multirow{2}{*}{$\begin{array}{l}\text { Triacylgly- } \\
\text { cerol synthesis }\end{array}$} & \multirow[t]{2}{*}{ Down } & Ppap $2 b$ & 67916 & Phosphatidic acid phosphatase type $2 \mathrm{~B}$ & -1.38 & 0.001 & -1.48 & 0.000 \\
\hline & & Dgat2 & 67800 & Diacylglycerol O-acyltransferase 2 & -1.31 & 0.003 & -1.37 & 0.006 \\
\hline \multirow{2}{*}{$\begin{array}{l}\text { Lipid droplet } \\
\text { formation }\end{array}$} & \multirow[t]{2}{*}{ Up/down } & $A d f p$ & 11520 & Adipose differentiation related protein & 5.97 & 0.000 & 6.60 & 0.000 \\
\hline & & Cav1 & 12389 & Caveolin, caveolae protein 1 & -2.20 & 0.000 & -2.30 & 0.001 \\
\hline $\begin{array}{l}\text { Glycerolipid } \\
\text { lysis }\end{array}$ & Up & Pnpla2 & 66853 & $\begin{array}{l}\text { Patatin-like phospholipase domain } \\
\text { containing } 2\end{array}$ & 1.52 & 0.006 & 1.67 & 0.007 \\
\hline \multirow{2}{*}{$\begin{array}{l}\text { Glycerol } \\
\text { metabolism }\end{array}$} & \multirow[t]{2}{*}{ Up } & $G k$ & 14933 & Glycerol kinase & 1.86 & 0.007 & 1.88 & 0.003 \\
\hline & & $G p d 1$ & 14555 & $\begin{array}{l}\text { Glycerol-3-phosphate dehydrogenase } 1 \\
\text { (soluble) }\end{array}$ & 2.07 & 0.009 & 1.68 & 0.032 \\
\hline $\begin{array}{l}\text { Energy } \\
\text { expenditure }\end{array}$ & Up & Ucp2 & 22228 & $\begin{array}{l}\text { Uncoupling protein } 2 \text { (mitochondrial, } \\
\text { proton carrier) }\end{array}$ & 1.78 & 0.001 & 1.50 & 0.003 \\
\hline \multirow{5}{*}{$\begin{array}{l}\text { Glutathione } \\
\text { metabolism }\end{array}$} & \multirow[t]{5}{*}{ Up/down } & Mgst3 & 66447 & Microsomal glutathione S-transferase 3 & 2.11 & 0.001 & 1.88 & 0.001 \\
\hline & & Gsta4 & 14860 & Glutathione S-transferase A4 & 1.36 & 0.046 & -1.01 & 0.924 \\
\hline & & Gstm1 & 14862 & Glutathione S-transferase M1 & -1.88 & 0.000 & -2.01 & 0.010 \\
\hline & & Gstt1 & 14871 & Glutathione S-transferase theta 1 & -1.38 & 0.060 & -1.51 & 0.044 \\
\hline & & Gstz1 & 14874 & Glutathione transferase zeta 1 & -1.44 & 0.001 & -1.57 & 0.015 \\
\hline \multirow{3}{*}{$\begin{array}{l}\text { Prostaglandin } \\
\text { metabolism }\end{array}$} & \multirow[t]{3}{*}{ Up/down } & Cbr3 & 109857 & Carbonyl reductase 3 & 3.04 & 0.000 & 3.96 & 0.000 \\
\hline & & Ptges 2 & 96979 & Prostaglandin E synthase 2 & 1.45 & 0.012 & 1.61 & 0.000 \\
\hline & & Ptgis & 19223 & Prostaglandin I2 (prostacyclin) synthase & -1.71 & 0.002 & -1.41 & 0.004 \\
\hline
\end{tabular}


Table 1. Key enzymes of metabolism pathways regulated by rosiglitazone (continued)

\begin{tabular}{|c|c|c|c|c|c|c|c|c|}
\hline \multirow[t]{2}{*}{ Pathway } & \multirow[t]{2}{*}{ Change } & \multirow[t]{2}{*}{ Gene } & \multirow[t]{2}{*}{ GeneID } & \multirow[t]{2}{*}{ Name } & \multicolumn{2}{|c|}{ Rosi/Basal } & \multicolumn{2}{|c|}{ RosiIG/IG } \\
\hline & & & & & $\begin{array}{l}\text { Fold - } \\
\text { change }\end{array}$ & $p$ & $\begin{array}{l}\text { Fold- } \\
\text { change }\end{array}$ & $p$ \\
\hline \multirow[t]{3}{*}{$\begin{array}{l}\text { Steroids } \\
\text { metabolism }\end{array}$} & Up/down & $H s d 17 b 7$ & 15490 & $\begin{array}{l}\text { Hydroxysteroid 17-beta dehydrogenase } \\
7\end{array}$ & 1.63 & 0.003 & 1.73 & 0.002 \\
\hline & & Nsdhl & 18194 & $\begin{array}{l}\text { NAD }(\mathrm{P}) \text { dependent steroid } \\
\text { dehydrogenase-like }\end{array}$ & 1.51 & 0.039 & 1.37 & 0.017 \\
\hline & & $H s d 11 b 1$ & 15483 & $\begin{array}{l}\text { Hydroxysteroid 11-beta dehydrogenase } \\
1\end{array}$ & -2.73 & 0.001 & -2.05 & 0.004 \\
\hline $\begin{array}{l}\text { Glyconeogene } \\
\text {-sis }\end{array}$ & Up & Fbp2 & 14120 & Fructose-1,6-bisphosphatase 2 & 2.92 & 0.003 & 2.82 & 0.014 \\
\hline $\begin{array}{l}\text { Glycogen } \\
\text { synthesis }\end{array}$ & Up & Gyg & 27357 & Glycogenin & 1.52 & 0.001 & 1.34 & 0.008 \\
\hline \multirow{2}{*}{$\begin{array}{l}\text { Pyruvate } \\
\text { metabolism }\end{array}$} & $\mathrm{Up}$ & Pdhal & 18597 & Pyruvate dehydrogenase E1 alpha 1 & 1.38 & 0.001 & 1.33 & 0.001 \\
\hline & & $P d h b$ & 68263 & $\begin{array}{l}\text { pyruvate dehydrogenase (lipoamide) } \\
\text { beta }\end{array}$ & 1.59 & 0.005 & 1.61 & 0.004 \\
\hline \multirow[t]{2}{*}{$\begin{array}{l}\text { Pentose } \\
\text { phosphate }\end{array}$} & Up & H6pd & 100198 & $\begin{array}{l}\text { Hexose-6-phosphate dehydrogenase } \\
\text { (glucose 1-dehydrogenase) }\end{array}$ & 1.60 & 0.000 & 1.47 & 0.001 \\
\hline & & Taldo1 & 21531 & Transaldolase 1 & 1.57 & 0.001 & 1.33 & 0.036 \\
\hline \multirow{2}{*}{$\begin{array}{l}\text { Leu } \\
\text { catabolism }\end{array}$} & Down & Ivd & 56357 & Isovaleryl Coenzyme A dehydrogenase & -1.42 & 0.004 & -1.72 & 0.000 \\
\hline & & $M c c c 1$ & 72039 & $\begin{array}{l}\text { Methylcrotonoyl-Coenzyme A } \\
\text { carboxylase } 1 \text { (alpha) }\end{array}$ & -1.26 & 0.026 & -1.35 & 0.031 \\
\hline
\end{tabular}

Mean value of microarray data $(n=5)$,

Rosi/basal: the effect with low insulin/glucose; RosiIG/IG: the effect with high insulin/glucose.

Effect of rosiglitazone on the expression of genes encoding adipocyte-secreted proteins To assess whether protein secretion by mature adipocytes is altered by rosiglitazone, we checked genes encoding adipocyte-secreted proteins. The list was based on literature [24-27] and our previous work [20]. In total, 61 genes were present on the array. Il-1-beta, Il6, Il10 and leptin showed very low signals (less than twofold of background) and were excluded from the analysis. Among the remaining 57 genes, only apolipoprotein E (Apoe) was up-regulated by Rosi treatment, and more than $40 \%$ of the genes were significantly down-regulated at both Rosi and RosilG treatment (Table 2).

Interestingly, the general down-regulation of adipokines was also observed for other genes encoding secreted proteins. We used Gene Ontology to cluster the expressed genes on the microarray into secreted protein encoding genes and intracellular/unknown location protein-encoding genes (additional gene expression information is available at www.foodbioactives.nl). In the first cluster, more genes were significantly downregulated (Fig.3a, c). Of 477 genes, $24.9 \%$ and $25.8 \%$ were significantly downregulated, while $9.6 \%$ and $6.7 \%$ were up-regulated by Rosi and RosiIG respectively. Of the up-regulated genes, most encode multi-location proteins, which can also reside in the nucleus, mitochondria and/or membranes. If these genes are omitted from the analysis, only seven genes were up-regulated (1.5\%). In the cellular protein cluster, by contrast, the majority of the regulated genes were up-regulated (Fig. 3b, d). Of 3382 
genes, $10.3 \%$ and $10.1 \%$ were significantly up-regulated, while $5.1 \%$ and $5.0 \%$ were down-regulated by Rosi and RosilG treatment respectively.

To complement array data, we used 2D and 1D gel electrophoresis and western blotting to examine the effect of rosiglitazone on secretion. With regard to complement $\mathrm{C} 3$, a $30 \%$ reduction of secretion by Rosi or RosilG treatment was observed on the $1 \mathrm{D}$ gel (Fig. 4). This is less than the change observed at the gene expression level. Nine spots on the 2D gel were identified as adipsin. We assessed the changes for individual spots, as well as for all spots in total. In both cases, the decrease effected by rosiglitazone at the gene expression level was similar to the decrease found at the secreted protein level with RosilG treatment. However, this decrease at the protein level was less prominent with Rosi treatment (Fig. 5). The secretion of adiponectin was also analysed by western blotting. A slight increase with rosiglitazone was detected (Fig. 6), although there was no change at the gene expression level.
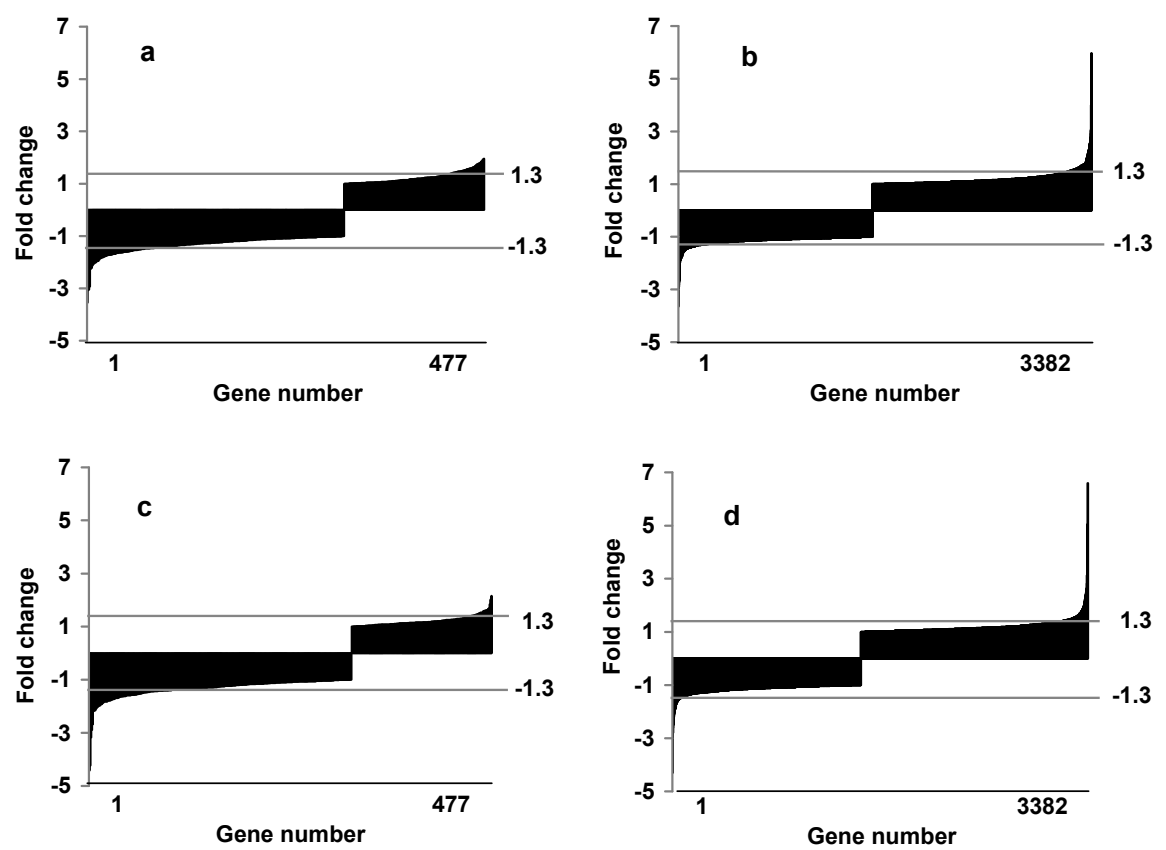

Fig. 3 Regulation pattern by rosiglitazone of genes encoding extracellular proteins and of genes encoding intracellular proteins or proteins of unknown location. (a, c): extracellular pattern; (b, d): intracellular pattern. $(a, b)$ : rosiglitazone with low insulin/glucose; $(c, d)$ : rosiglitazone with high insulin/glucose. 
Table 2. Effect of rosiglitazone on the expression of genes encoding adipocyte-secreted proteins.

\begin{tabular}{|c|c|c|c|c|c|c|c|}
\hline \multirow[t]{2}{*}{ Function } & \multicolumn{2}{|c|}{ Gene symbol GeneID } & \multirow[t]{2}{*}{ Name } & \multicolumn{2}{|c|}{ Rosi / Basal } & \multicolumn{2}{|c|}{ RosiIG / IG } \\
\hline & & & & $\begin{array}{l}\text { Fold - } \\
\text { change }\end{array}$ & $p$ & $\begin{array}{l}\text { Fold- } \\
\text { change }\end{array}$ & $p$ \\
\hline \multirow[t]{4}{*}{ Lipid metabolism } & $A d n$ & 11537 & Complement factor D (adipsin) & -3.55 & 0.000 & -4.23 & 0.000 \\
\hline & $C 3$ & 12266 & Complement component 3 & -2.25 & 0.000 & -2.68 & 0.001 \\
\hline & $\mathrm{Lpl}$ & 16956 & Lipoprotein lipase & 1.12 & 0.166 & -1.02 & 0.627 \\
\hline & Apoe & 11816 & Apolipoprotein E & 1.34 & 0.026 & 1.18 & 0.145 \\
\hline \multirow[t]{4}{*}{ Insulin sensitivity } & Retn & 57264 & Resistin & -3.07 & 0.000 & -3.17 & 0.001 \\
\hline & $\operatorname{Igfl}$ & 16000 & Insulin-like growth factor 1 & -1.55 & 0.012 & -1.58 & 0.001 \\
\hline & Pbef1 & 59027 & $\begin{array}{l}\text { Pre-B-cell colony-enhancing } \\
\text { factor } 1\end{array}$ & -1.24 & 0.050 & -1.28 & 0.085 \\
\hline & Adipoq & 11450 & Adiponectin & -1.09 & 0.462 & -1.25 & 0.108 \\
\hline \multirow[t]{15}{*}{ Inflammation } & $H p$ & 15439 & Haptoglobin & -2.93 & 0.000 & -4.42 & 0.000 \\
\hline & Ptx 3 & 19288 & Pentaxin related gene & -1.68 & 0.001 & -1.58 & 0.000 \\
\hline & $T g f b 3$ & 21809 & $\begin{array}{l}\text { Transforming growth factor, } \\
\text { beta } 3\end{array}$ & -1.58 & 0.008 & -1.44 & 0.056 \\
\hline & $B 2 m$ & 12010 & Beta-2 microglobulin & -1.54 & 0.018 & -1.64 & 0.006 \\
\hline & $\mathrm{Ccl} 2$ & 20296 & $\begin{array}{l}\text { chemokine (C-C motif) ligand } \\
2\end{array}$ & -1.54 & 0.012 & -1.48 & 0.023 \\
\hline & Saa3 & 20210 & Serum amyloid A 3 & -1.49 & 0.047 & -1.38 & 0.001 \\
\hline & Cxcl12 & 20315 & $\begin{array}{l}\text { chemokine (C-X-C motif) } \\
\text { ligand } 12\end{array}$ & -1.45 & 0.006 & -1.42 & 0.046 \\
\hline & Il6ra & 16194 & Interleukin 6 receptor, alpha & -1.16 & 0.128 & -1.15 & 0.037 \\
\hline & $T g f b l$ & 21803 & $\begin{array}{l}\text { Transforming growth factor, } \\
\text { beta } 1\end{array}$ & -1.15 & 0.163 & 1.02 & 0.914 \\
\hline & $\operatorname{Tg} f b 2$ & 21808 & $\begin{array}{l}\text { Transforming growth factor, } \\
\text { beta } 2\end{array}$ & -1.15 & 0.306 & -1.07 & 0.584 \\
\hline & Ill 18 & 16173 & Interleukin 18 & -1.15 & 0.224 & -1.01 & 0.937 \\
\hline & D17Wsulc & 28106 & SF20/IL25 & -1.03 & 0.794 & -1.16 & 0.088 \\
\hline & Lgals1 & 16852 & $\begin{array}{l}\text { Lectin, galactose binding, } \\
\text { soluble } 1\end{array}$ & 1.05 & 0.774 & 1.08 & 0.590 \\
\hline & Len2 & 16819 & Lipocalin 2 & 1.11 & 0.228 & 1.20 & 0.179 \\
\hline & Mif & 17319 & $\begin{array}{l}\text { Macrophage migration } \\
\text { inhibitory factor }\end{array}$ & 1.18 & 0.076 & 1.17 & 0.137 \\
\hline \multirow[t]{2}{*}{ Antioxidant } & Sod3 & 20657 & $\begin{array}{l}\text { Superoxide dismutase } 3 \text {, } \\
\text { extracellular }\end{array}$ & -1.09 & 0.500 & -1.39 & 0.036 \\
\hline & Mt1 & 17748 & Metallothionein 1 & -1.11 & 0.577 & -1.12 & 0.417 \\
\hline \multirow[t]{6}{*}{ Vascular function } & $A d m$ & 11535 & Adrenomedullin & -1.41 & 0.003 & -1.50 & 0.000 \\
\hline & Agt & 11606 & Angiotensinogen & -1.22 & 0.161 & -1.15 & 0.150 \\
\hline & Serpinfl & 20317 & $\begin{array}{l}\text { serine (or cysteine) peptidase } \\
\text { inhibitor, clade F, member } 1 \\
\text { (Pigment epithelium-derived } \\
\text { factor) }\end{array}$ & -1.15 & 0.237 & -1.25 & 0.187 \\
\hline & $V e g f a$ & 22339 & $\begin{array}{l}\text { Vascular endothelial growth } \\
\text { factor A }\end{array}$ & -1.03 & 0.724 & -1.08 & 0.644 \\
\hline & Apln & 30878 & Apelin & 1.01 & 0.969 & 1.02 & 0.790 \\
\hline & Serpinel & 18787 & $\begin{array}{l}\text { serine (or cysteine) peptidase } \\
\text { inhibitor, clade E, member } 1 \\
\text { (Plasminogen activator } \\
\text { inhibitor-1) }\end{array}$ & -1.01 & 0.897 & 1.27 & 0.013 \\
\hline
\end{tabular}


Table 2. Effect of rosiglitazone on the expression of genes encoding adipocyte-secreted proteins (continued)

\begin{tabular}{|c|c|c|c|c|c|c|c|}
\hline \multirow[t]{2}{*}{ Function } & \multirow[t]{2}{*}{ Gene } & \multirow[t]{2}{*}{ GeneID } & \multirow[t]{2}{*}{ Name } & \multicolumn{2}{|c|}{ Rosi / Basal } & \multicolumn{2}{|c|}{ RosiIG / IG } \\
\hline & & & & $\begin{array}{l}\text { Fold - } \\
\text { change }\end{array}$ & $p$ & $\begin{array}{l}\text { Fold- } \\
\text { change }\end{array}$ & $p$ \\
\hline \multirow{15}{*}{$\begin{array}{l}\text { Extracellular } \\
\text { matrix component }\end{array}$} & Nid2 & 18074 & Nidogen 2 & -1.64 & 0.002 & -1.96 & 0.003 \\
\hline & Sparc & 20692 & $\begin{array}{l}\text { Secreted acidic cysteine rich } \\
\text { glycoprotein }\end{array}$ & -1.63 & 0.000 & -1.56 & 0.000 \\
\hline & Col5a2 & 12832 & Procollagen, type V, alpha 2 & -1.62 & 0.000 & -1.62 & 0.003 \\
\hline & Col5al & 12831 & Procollagen, type V, alpha 1 & -1.59 & 0.003 & -1.48 & 0.013 \\
\hline & Colla2 & 12843 & Procollagen, type I, alpha 2 & -1.64 & 0.020 & -1.40 & 0.002 \\
\hline & Colla1 & 12842 & Procollagen, type I, alpha 1 & -1.60 & 0.065 & -1.38 & 0.020 \\
\hline & Col3al & 12825 & Procollagen, type III, alpha 1 & -1.52 & 0.024 & -1.59 & 0.002 \\
\hline & Col4a5 & 12830 & Procollagen, type IV, alpha 5 & -1.44 & 0.034 & -1.37 & 0.019 \\
\hline & Col6a2 & 12834 & Procollagen, type VI, alpha 2 & -1.32 & 0.011 & -1.19 & 0.108 \\
\hline & Col6al & 12833 & Procollagen, type VI, alpha 1 & -1.31 & 0.117 & 1.05 & 0.740 \\
\hline & Col5a3 & 53867 & Procollagen, type V, alpha 3 & -1.20 & 0.046 & -1.29 & 0.076 \\
\hline & Col4al & 12826 & Procollagen, type IV, alpha 1 & -1.16 & 0.114 & -1.16 & 0.069 \\
\hline & Col4a2 & 12827 & Procollagen, type IV, alpha 2 & -1.16 & 0.153 & -1.29 & 0.003 \\
\hline & Nid1 & 18073 & Nidogen 1 & -1.04 & 0.723 & 1.04 & 0.767 \\
\hline & Col6a3 & 12835 & Procollagen, type VI, alpha 3 & -1.03 & 0.690 & -1.01 & 0.960 \\
\hline \multirow{9}{*}{$\begin{array}{l}\text { Extracellular } \\
\text { matrix processing }\end{array}$} & Mmp3 & 17392 & Matrix metalloproteinase 3 & -2.01 & 0.003 & -2.02 & 0.013 \\
\hline & Lox & 16948 & Lysyl oxidase & -1.87 & 0.005 & -2.17 & 0.002 \\
\hline & Timp2 & 21858 & $\begin{array}{l}\text { Tissue inhibitor of } \\
\text { metalloproteinase } 2\end{array}$ & -1.81 & 0.002 & -1.92 & 0.000 \\
\hline & Mmp2 & 17390 & Matrix metalloproteinase 2 & -1.44 & 0.054 & -1.30 & 0.100 \\
\hline & Timp1 & 21857 & $\begin{array}{l}\text { Tissue inhibitor of } \\
\text { metalloproteinase } 1\end{array}$ & -1.32 & 0.095 & -1.30 & 0.055 \\
\hline & Pcolce & 18542 & $\begin{array}{l}\text { procollagen C-endopeptidase } \\
\text { enhancer protein }\end{array}$ & -1.31 & 0.029 & -1.48 & 0.002 \\
\hline & Mmp19 & 58223 & Matrix metalloproteinase 19 & -1.01 & 0.848 & -1.08 & 0.347 \\
\hline & Mmpl1 & 17385 & Matrix metalloproteinase 11 & 1.05 & 0.860 & -1.12 & 0.413 \\
\hline & Timp4 & 110595 & $\begin{array}{l}\text { Tissue inhibitor of } \\
\text { metalloproteinase } 4\end{array}$ & 1.06 & 0.672 & 1.25 & 0.055 \\
\hline \multirow[t]{3}{*}{ Miscellaneous } & Gal & 14419 & Galanin & -3.04 & 0.000 & -2.89 & 0.000 \\
\hline & Gsn & 227753 & Gelsolin & -1.63 & 0.000 & -1.52 & 0.000 \\
\hline & Ppic & 19038 & Peptidylprolyl isomerase $\mathrm{C}$ & -1.27 & 0.049 & -1.38 & 0.001 \\
\hline
\end{tabular}

Mean value of microarray data $(\mathrm{n}=5)$,

Rosi/basal: the effect with low insulin/glucose; RosiIG/IG: the effect with high insulin/glucose. 


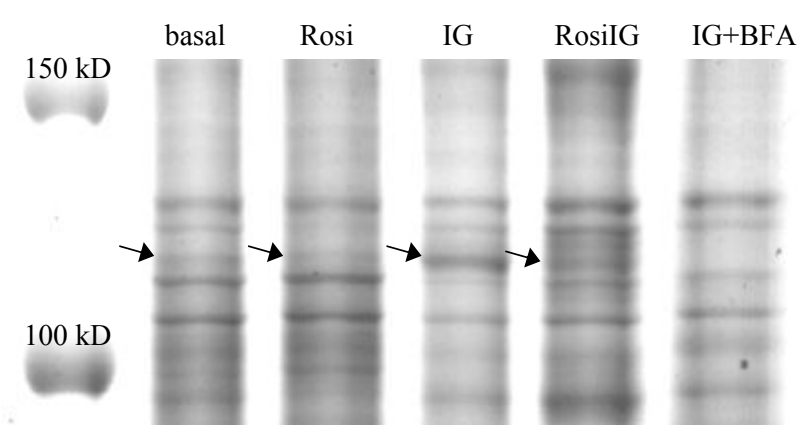

Fig. 4 The effect of rosiglitazone on the secretion of complement $\mathrm{C} 3$ as measured by $1 \mathrm{D}$ gel analysis. The marked bands were identified as $\mathrm{C} 3$. One representative image is shown. A sample treated by brefeldin A (IG+BFA) was used to verify secretion.
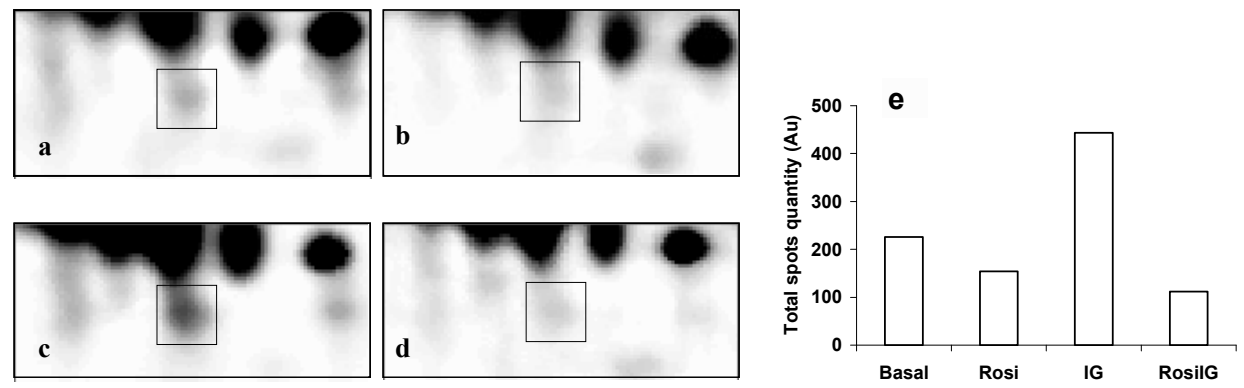

Fig. 5 The effect of rosiglitazone on the secretion of adipsin as measured by $2 \mathrm{D}$ gel analysis. A section of one representative 2D gel image is shown for an individual adipsin spot (marked in square) from the condition (a) low glucose and insulin control condition (Basal), (b) rosiglitazone with low insulin and glucose condition (Rosi), (c) high glucose and insulin control condition (IG) and (d) rosiglitazone with high insulin and glucose condition (RosiIG). (e) Total quantity of adipsin in the culture medium of 3T3-L1 adipocytes expressed in arbitury unit ( $\mathrm{Au})$. 


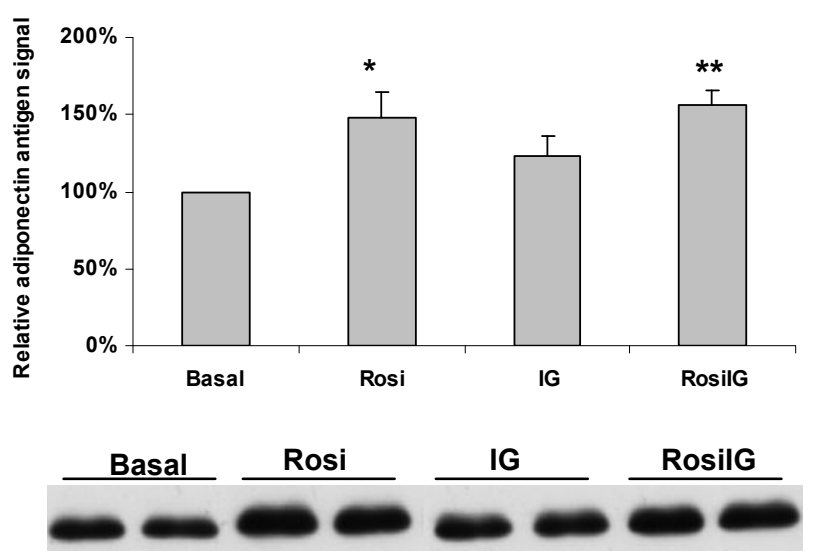

Fig. 6 The effect of rosiglitazone on the secretion of adiponectin as measured by western blotting. Data are expressed as mean $\pm \mathrm{SD}(n=3)$ and one representative western blot image is shown. * $p<0.05$ compared with Basal condition (t test); ${ }^{* *} p<0.01$ compared with IG condition ( $\mathrm{t}$ test). Basal, low glucose and insulin control condition; Rosi, rosiglitazone with low insulin and glucose condition; IG, high glucose and insulin control condition; RosilG, rosiglitazone with high insulin and glucose condition

General confirmation of the microarray data by quantitative real-time RT- PCR analysis To confirm our microarray data, we checked the expression of 22 genes that encode secreted proteins or are related to lipid metabolism, by Q-PCR, using Rps 15 as reference. Rps 15 was chosen because of its constant expression behaviour on the arrays. A gene was selected as target gene because either itself or its family member showed changed expression based on microarray data. The comparison showed a strong correlation between array data and Q-PCR data (Supplementary Fig. 1), with Pearson correlation coefficients of 0.987 and 0.986 for Rosi/basal and RosiIG/IG, respectively.

The effect of rosiglitazone on lipolysis We assessed the glycerol level in the culture medium as a measure of the lipolysis of adipocytes. RosilG treatment significantly increased the release of glycerol from 3T3-L1 mature adipocytes, whereas glycerol release was significantly decreased by Rosi treatment (Fig. 7). 


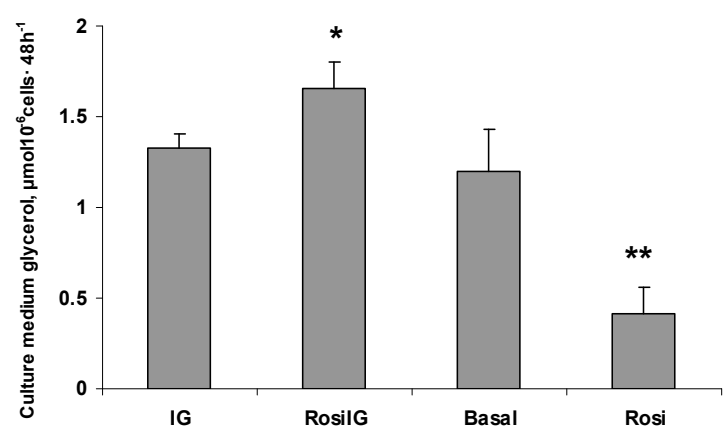

Fig. 7 The effect of rosiglitazone on the culture medium glycerol levels. Data are expressed as mean $\pm \mathrm{SD}(n=3) . * p<0.05$ compared with IG condition ( $\mathrm{t}$ test); $* * p<0.01$ compared with Basal condition ( $t$ test). Basal, low glucose and insulin control condition; Rosi, rosiglitazone with low insulin and glucose condition; IG, high glucose and insulin control condition; RosilG, rosiglitazone with high insulin and glucose condition.

\section{Discussion}

As a PPARG agonist, rosiglitazone stimulates adipogenesis, which is accompanied by an increasing lipid content of the differentiating cells. However, our results showed that rosiglitazone does not induce an increase of the lipid content, but decreases it in mature adipocytes at high insulin/glucose level. The pathway analysis based on transcriptome data points out that an altered energy metabolism may underlie this phenomenon.

Although the level of insulin/glucose has some influence, the effect of rosiglitazone on the transcriptome was clearly dominant. The most significantly regulated pathways by rosiglitazone in 3T3-L1 adipocytes were fatty acid oxidation, the TCA cycle and oxidative phosphorylation. Besides an up-regulation of fatty acid catabolism pathways, our data indicate that rosiglitazone favours adipocytes to utilise fatty acids for energy production and spares glucose and amino acids by enhancing glycogen synthesis and inhibiting amino acid catabolism pathways. This is in line with the up-regulation of $U c p 2$ and the down-regulation of $S c d 1$ expression. The increase of UCP2 is correlated with a shift in substrate utilisation in favour of lipids as the dominant metabolic fuel [28]. SCD1 is involved in fatty acids synthesis, but it has also been shown that SCD1 deficiency activates metabolic pathways that promote beta-oxidation and decrease lipogenesis [29].

Our conclusions regarding energy metabolism are consistent with recent studies. Mitochondrial changes have been shown in response to TZD treatment in 3T3-L1 adipocytes [30], human adipocytes in vitro [31] and mouse adipocytes in vivo [12]. These studies show that TZDs, including rosiglitazone, up-regulate fatty acid oxidation by increasing mitochondrial protein and gene expression, but not in a transdifferentiation manner $[12,30]$. This has been confirmed by direct measurement of labelled palmitic acid oxidation [12] or indirect calorimetric calculation [32]. We also found that among the genes involved in protein biosynthesis, over $80 \%$ of those up- 
regulated by rosiglitazone were genes encoding mitochondrial ribosomal proteins. This is consistent with an increase of mitochondrial biogenesis and remodelling [12]. We speculate that the maintenance of increased mitochondrial mass and function utilises (part of) the energy that the cell no longer needs for lipid synthesis under rosiglitazone treatment.

A decrease in lipogenesis pathways accompanies the increased fatty acid catabolism pathways caused by rosiglitazone in mature adipocytes, as shown by decreased expression of genes encoding triacylglycerol synthesis enzymes and increased lipase gene expression. The down-regulation of Fasn by TZD has also been observed in brown adipocytes [33]. Caveolin-1 (CAV1) is an important protein for efficient lipid droplet formation [34]. The down-regulation of its gene expression supports a decrease of lipid accumulation. The up-regulation of adipocyte differentiation related protein gene (Adfp), which encodes a lipid droplet-associated protein, seems to conflict with the decreased lipogenesis observed by us (Table 1). However, in mature 3T3-L1 adipocytes, ADFP is spatially associated with lipid droplets subjected to lipolysis and is suggested to play a role in lipolysis [35]. Furthermore, the protein level of ADFP in mature adipocytes is not determined by the mRNA level, but by the amount of micro-lipid droplets [35]. Therefore the increase of $A d f p$ expression might also be interpreted as being in agreement with up-regulated lipolysis.

The pentose phosphate pathway provides NADPH to be used in reductive biosynthesis, including fatty acid biosynthesis [36]. Rosiglitazone enhances the pentose phosphate pathway, but inhibits fatty acid biosynthesis, while stimulating other NADPHdependent pathways, such as glutathione detoxification, cholesterol and steroid biosynthesis, and prostaglandin metabolism (carbonyl reductase 3 ). The excess of NADPH may be a driving force behind the up-regulation of these pathways by rosiglitazone.

The present study indicates that in mature 3T3-L1 adipocytes rosiglitazone enhances fatty acid catabolism, increases lipolysis and reduces lipogenesis pathways. This may lead to a net decrease of lipid content of the cells. Indeed, we observed increased lipolysis expressed in terms of an increased glycerol level in the medium and a decreased lipid content of the cells under RosilG treatment. This is in line with the increased lipolysis effected by rosiglitazone in a recent study on rat white adipose tissue [37]. We did not observe increased lipolysis under Rosi treatment, where in fact the glycerol level was decreased rather than increased. The difference implies that the insulin/glucose level alters the effect of rosiglitazone. It is likely that at low insulin/glucose level, the 'starved' adipocytes use glycerol as an energy source, rather than releasing it into the medium. However, it should be noted that low insulin/glucose is not a realistic situation in vivo when rosiglitazone is administered. The decreased lipid content is consistent with the physiological effects of TZDs in both animal models [10, 38] and in humans [9], where TZDs increase the number of small adipocytes. In adipose tissue treated with TZDs, mature adipocytes can become smaller by actively burning fat, in parallel to the emerging of small immature adipocytes due to preadipocyte differentiation. With rosiglitazone, mature adipocytes take fatty acids for burning rather 
than for storage. This still fits the 'fatty acid steal' hypothesis [1] and can explain part of the anti-diabetic effects of rosiglitazone.

Rosiglitazone affects the function of mature adipocytes not only with respect to fat metabolism, but also with respect to adipokine secretion. Despite the limitations of the present study, namely that a mid-size array was used and that the expression changes of several genes could not be detected due to sensitivity, our data at both the mRNA level and the protein level confirmed that rosiglitazone represses adipokine expression, except adiponectin and Apoe. Since the majority of adipokines are negatively correlated with insulin sensitivity [39], the general repression may correct the disturbance of insulin sensitivity caused by obesity. Furthermore, our transcriptome analysis suggests that rosiglitazone induces a general decrease in expression of genes encoding secreted proteins. This implies a general mechanism, in which energy redistribution might be involved.

We observed that repression at the secretion level was less significant than at the gene expression level. One explanation is that the effect on protein lags behind the effect on mRNA. Another reason might be the influence of insulin. We have recently studied the role of insulin in 3T3-L1 adipocyte secretion [19]. We observed that at a low insulin level, the secretion of proteins is already suppressed. Consequently, the inhibitory effect of rosiglitazone on secretion is less prominent in the low insulin condition.

In contrast to most adipokines, adiponectin is reversely correlated with obesity, and its circulating level is up-regulated by TZDs [40]. A functional PPAR-responsive element (PPRE) in the adiponectin promoter could be the reason for the stimulation [41]. We observed an up-regulation only at the secretion level, but not at gene expression level. This is in line with the conclusion from another study, that although plasma levels of adiponectin were up-regulated by TZDs, there was no significant effect on adiponectin gene expression [16].

Rosiglitazone is a potent PPARG agonist. It seems logical to assume that all these effects are mediated through regulation of PPARG. Indeed, we observed that rosiglitazone induced a significant decrease of Pparg expression in mature 3T3-L1 adipocytes. This is in contrast to an overwhelming increase during adipogenesis, but it is in line with several reports [42-44]. With respect to PPARG downstream effects, we found here that two PPRE-bearing genes, Cavl and $S c d 1$, were down-regulated, and two other genes, adiponectin and lipoprotein lipase, remained unchanged, while most PPRE-bearing genes [45], such as CD36 antigen, fatty acid binding protein 4, adipocyte and acyl-Coenzyme A oxidase 1, palmitoyl, were up-regulated by rosiglitazone (Tables 1 and 2). The effect of TZDs on $S c d 1$ in mature adipocytes is opposite to that in preadipocytes [46], and the effect on Cavl is in contrast to the reports in other cell types $[47,48]$. It has been known that PPARG acts with different transcriptional partners, corepressors and/or co-activators as a complex, to activate or repress the expression of target genes [49, 50]. Possibly, the PPARG complex is modulated by rosiglitazone in mature adipocytes in a manner that is different from that occurring in preadipocytes and other cell types. 


\section{Conclusion}

We have shown that rosiglitazone, in contrast to the stimulation of adipogenesis in preadipocytes, reduces adiposity of mature adipocytes by increasing fatty acid catabolism pathways. In addition, rosiglitazone represses the expression and secretion of adipokines of mature adipocytes. Our findings suggest that the change of adiposity as seen in vivo [13] may reflect a shift in balance between the effects of TZDs on preadipocytes and those on mature adipocytes, while the changes in circulating adipokine levels primarily result from an effect on mature adipocytes. These aspects all contribute to the therapeutic effects of TZDs.

Acknowledgements We thank our colleagues in the Functional Genomics Group and the Food Bioactives Group, especially V. de Boer, for technical support and helpful discussions. We also thank GlaxoSmithKline for the gift of rosiglitazone. This study was financed by the Centre for Human Nutrigenomics in the Netherlands.

\section{References}

1. Yki-Jarvinen, H., Thiazolidinediones. N Engl J Med, 2004. 351(11): p. 1106-18.

2. Olefsky, J.M., Treatment of insulin resistance with peroxisome proliferator-activated receptor gamma agonists. J Clin Invest, 2000. 106(4): p. 467-72.

3. Larsen, T.M., S. Toubro, and A. Astrup, PPARgamma agonists in the treatment of type II diabetes: is increased fatness commensurate with long-term efficacy? Int J Obes Relat Metab Disord, 2003. 27(2): p. 147-61.

4. Kintscher, U. and R.E. Law, PPARgamma-mediated insulin sensitization: the importance of fat versus muscle. Am J Physiol Endocrinol Metab, 2005. 288(2): p. E287-91.

5. Rosen, E.D., et al., C/EBPalpha induces adipogenesis through PPARgamma: a unified pathway. Genes Dev, 2002. 16(1): p. 22-6.

6. Gregoire, F.M., C.M. Smas, and H.S. Sul, Understanding adipocyte differentiation. Physiol Rev, 1998. 78(3): p. 783-809.

7. Hutley, L.J., et al., Effects of rosiglitazone and linoleic acid on human preadipocyte differentiation. Eur J Clin Invest, 2003. 33(7): p. 574-81.

8. Shao, D. and M.A. Lazar, Peroxisome proliferator activated receptor gamma, CCAAT/enhancer-binding protein alpha, and cell cycle status regulate the commitment to adipocyte differentiation. J Biol Chem, 1997. 272(34): p. 21473-8.

9. Boden, G., et al., Effect of thiazolidinediones on glucose and fatty acid metabolism in patients with type 2 diabetes. Metabolism, 2003. 52(6): p. 753-9.

10. de Souza, C.J., et al., Effects of pioglitazone on adipose tissue remodeling within the setting of obesity and insulin resistance. Diabetes, 2001. 50(8): p. 1863-71.

11. Fonseca, V., Effect of thiazolidinediones on body weight in patients with diabetes mellitus. Am J Med, 2003. 115 Suppl 8A: p. 42S-48S.

12. Wilson-Fritch, L., et al., Mitochondrial remodeling in adipose tissue associated with obesity and treatment with rosiglitazone. J Clin Invest, 2004. 114(9): p. 1281-9.

13. Miyazaki, Y., et al., Effect of pioglitazone on abdominal fat distribution and insulin sensitivity in type 2 diabetic patients. J Clin Endocrinol Metab, 2002. 87(6): p. 2784-91.

14. Fasshauer, M. and R. Paschke, Regulation of adipocytokines and insulin resistance. Diabetologia, 2003. 46(12): p. 1594-603.

15. Tonelli, J., et al., Mechanisms of early insulin-sensitizing effects of thiazolidinediones in type 2 diabetes. Diabetes, 2004. 53(6): p. 1621-9.

16. Rasouli, N., et al., Increased plasma adiponectin in response to pioglitazone does not result from increased gene expression. Am J Physiol Endocrinol Metab, 2006. 290(1): p. E42-6.

17. Mattoo, V., et al., Metabolic effects of pioglitazone in combination with insulin in patients with type 2 diabetes mellitus whose disease is not adequately controlled with insulin therapy: results of a six-month, 
randomized, double-blind, prospective, multicenter, parallel-group study. Clin Ther, 2005. 27(5): p. 55467.

18. Mohanty, P., et al., Evidence for a potent antiinflammatory effect of rosiglitazone. J Clin Endocrinol Metab, 2004. 89(6): p. 2728-35.

19. Wang, P., et al., Insulin modulates the secretion of proteins from mature 3T3-L1 adipocytes: a role for transcriptional regulation of processing. Diabetologia, 2006. 49(10): p. 2453-62.

20. Wang, P., et al., Profiling of the secreted proteins during 3T3-L1 adipocyte differentiation leads to the identification of novel adipokines. Cell Mol Life Sci, 2004. 61(18): p. 2405-17.

21. Koopman, R., G. Schaart, and M.K. Hesselink, Optimisation of oil red O staining permits combination with immunofluorescence and automated quantification of lipids. Histochem Cell Biol, 2001. 116(1): p. 63-8.

22. Bouwman, F., J. Renes, and E. Mariman, A combination of protein profiling and isotopomer analysis using matrix-assisted laser desorption/ionization-time of flight mass spectrometry reveals an active metabolism of the extracellular matrix of 3T3-L1 adipocytes. Proteomics, 2004. 4(12): p. 3855-63.

23. Berger, J., et al., Peroxisome proliferator-activated receptor-gamma ligands inhibit adipocyte 11 beta hydroxysteroid dehydrogenase type 1 expression and activity. J Biol Chem, 2001. 276(16): p. 12629-35.

24. Rajala, M.W. and P.E. Scherer, Minireview: The adipocyte--at the crossroads of energy homeostasis, inflammation, and atherosclerosis. Endocrinology, 2003. 144(9): p. 3765-73.

25. Krug, A.W. and M. Ehrhart-Bornstein, Newly discovered endocrine functions of white adipose tissue: possible relevance in obesity-related diseases. Cell Mol Life Sci, 2005. 62(12): p. 1359-62.

26. Maquoi, E., et al., Modulation of adipose tissue expression of murine matrix metalloproteinases and their tissue inhibitors with obesity. Diabetes, 2002. 51(4): p. 1093-101.

27. Trayhurn, P. and I.S. Wood, Adipokines: inflammation and the pleiotropic role of white adipose tissue. Br J Nutr, 2004. 92(3): p. 347-55.

28. Dulloo, A.G., J. Seydoux, and J. Jacquet, Adaptive thermogenesis and uncoupling proteins: a reappraisal of their roles in fat metabolism and energy balance. Physiol Behav, 2004. 83(4): p. 587-602.

29. Ntambi, J.M., et al., Loss of stearoyl-CoA desaturase-1 function protects mice against adiposity. Proc Natl Acad Sci U S A, 2002. 99(17): p. 11482-6.

30. Wilson-Fritch, L., et al., Mitochondrial biogenesis and remodeling during adipogenesis and in response to the insulin sensitizer rosiglitazone. Mol Cell Biol, 2003. 23(3): p. 1085-94.

31. Bogacka, I., et al., Structural and functional consequences of mitochondrial biogenesis in human adipocytes in vitro. J Clin Endocrinol Metab, 2005. 90(12): p. 6650-6.

32. Boden, G., et al., Thiazolidinediones upregulate fatty acid uptake and oxidation in adipose tissue of diabetic patients. Diabetes, 2005. 54(3): p. 880-5.

33. Teruel, T., et al., Rosiglitazone up-regulates lipoprotein lipase, hormone-sensitive lipase and uncoupling protein-1, and down-regulates insulin-induced fatty acid synthase gene expression in brown adipocytes of Wistar rats. Diabetologia, 2005. 48(6): p. 1180-8.

34. Cohen, A.W., et al., Role of caveolin-1 in the modulation of lipolysis and lipid droplet formation. Diabetes, 2004. 53(5): p. 1261-70.

35. Brasaemle, D.L., et al., Proteomic analysis of proteins associated with lipid droplets of basal and lipolytically stimulated 3T3-L1 adipocytes. J Biol Chem, 2004. 279(45): p. 46835-42.

36. Berg, J., et al., Biochmistry. 5th ed. 2002, New York: W. H. Freeman and Company.

37. Festuccia, W.T., et al., PPARgamma agonism increases rat adipose tissue lipolysis, expression of glyceride lipases, and the response of lipolysis to hormonal control. Diabetologia, 2006. 49(10): p. 242736.

38. Okuno, A., et al., Troglitazone increases the number of small adipocytes without the change of white adipose tissue mass in obese Zucker rats. J Clin Invest, 1998. 101(6): p. 1354-61.

39. Lazar, M.A., How obesity causes diabetes: not a tall tale. Science, 2005. 307(5708): p. 373-5.

40. Hammarstedt, A., et al., The effect of PPARgamma ligands on the adipose tissue in insulin resistance. Prostaglandins Leukot Essent Fatty Acids, 2005. 73(1): p. 65-75.

41. Iwaki, M., et al., Induction of adiponectin, a fat-derived antidiabetic and antiatherogenic factor, by nuclear receptors. Diabetes, 2003. 52(7): p. 1655-63.

42. Rosenbaum, S.E. and A.S. Greenberg, The short- and long-term effects of tumor necrosis factor-alpha and BRL 49653 on peroxisome proliferator-activated receptor (PPAR)gamma2 gene expression and other adipocyte genes. Mol Endocrinol, 1998. 12(8): p. 1150-60.

43. Hauser, S., et al., Degradation of the peroxisome proliferator-activated receptor gamma is linked to ligand-dependent activation. J Biol Chem, 2000. 275(24): p. 18527-33.

44. Takamura, T., et al., Stage-specific effects of a thiazolidinedione on proliferation, differentiation and PPARgamma mRNA expression in 3T3-L1 adipocytes. Eur J Pharmacol, 2001. 422(1-3): p. 23-9.

45. Desvergne, B. and W. Wahli, Peroxisome proliferator-activated receptors: nuclear control of metabolism. Endocr Rev, 1999. 20(5): p. 649-88. 
46. Kurebayashi, S., et al., Thiazolidinediones downregulate stearoyl-CoA desaturase 1 gene expression in 3T3-L1 adipocytes. Diabetes, 1997. 46(12): p. 2115-8.

47. Llaverias, G., et al., Rosiglitazone upregulates caveolin-1 expression in THP-1 cells through a PPARdependent mechanism. J Lipid Res, 2004. 45(11): p. 2015-24.

48. Chintharlapalli, S., et al., 1,1-Bis(3'-indolyl)-1-(p-substituted phenyl)methanes induce peroxisome proliferator-activated receptor gamma-mediated growth inhibition, transactivation, and differentiation markers in colon cancer cells. Cancer Res, 2004. 64(17): p. 5994-6001.

49. Tan, N.S., et al., Multiple expression control mechanisms of peroxisome proliferator-activated receptors and their target genes. J Steroid Biochem Mol Biol, 2005. 93(2-5): p. 99-105.

50. Guan, H.P., et al., Corepressors selectively control the transcriptional activity of PPARgamma in adipocytes. Genes Dev, 2005. 19(4): p. 453-61. 
Chapter 4. Rosiglitazone effects on mature adipocytes 


\section{The circulating PBEF/NAMPT/visfatin level is associated with a beneficial blood lipid profile}

Ping Wang ${ }^{1}$, Marleen M.J. van Greevenbroek², Freek G. Bouwman'1, Martijn C.G.J Brouwers $^{2}$, Carla J.H. van der Kallen ${ }^{2}$, Egbert Smit ${ }^{1}$, Jaap Keijer ${ }^{3}$, Edwin C.M. Mariman $^{1}$

${ }^{1}$ Dept. Human Biology, Nutrition and Toxicology Research Institute Maastricht, Maastricht University, the Netherlands. ${ }^{2}$ Dept. Internal Medicine, Cardiovascular Research Institute Maastricht, Academic Hospital Maastricht and University of Maastricht, Maastricht, the Netherlands. ${ }^{3}$ Food Bioactives Group, RIKILT-Institute of Food Safety, Wageningen, the Netherlands

Submitted 


\begin{abstract}
Objective Visfatin is a recently discovered adipokine that was shown to be associated with visceral fat. Visfatin has been identified as Pre-B-cell colony-enhancing factor 1 (PBEF) and nicotinamide phosphoribosyltransferase (NAMPT). To explore the link of $\mathrm{PBEF} / \mathrm{NAMPT} / \mathrm{visfatin}$ with fat storage and metabolism, we analyzed the relation of its plasma level with several parameters of adiposity and the circulating blood lipid profile in both relatives $(n=35)$ and spouse controls $(n=40)$ of familial combined hyperlipidemia (FCHL) families.

Results In both groups, plasma level of PBEF/NAMPT/visfatin lacked association with whole body adiposity and visceral fat size, but correlated positively with HDLcholesterol and negatively with triglycerides.

Conclusions In humans, circulating PBEF/NAMPT/visfatin is not determined by lipid storage in adipose tissue. Rather, it is an indicator of a beneficial lipid profile regardless of genetic background of lipid metabolism. We speculate that this may be related to its enzymatic function in NAD metabolism.
\end{abstract}

\title{
Key words:
}

Adipokine, adipose tissue, HDL-cholesterol, NAD metabolism, triglycerides

\section{Abbreviations:}

BMI: body mass index; FCHL: familial combined hyperlipidemia; NAMPT: nicotinamide phosphoribosyltransferase; PBEF: Pre-B-cell colony-enhancing factor 1.

Footnote: ${ }^{1}$ in the remaining of the text, PBEF was used to refer to the protein PBEF/NAMPT/visfatin. 


\section{Introduction}

Following the discovery of leptin, adipose tissue is endowed with an important endocrine function. It secretes a number of peptides, adipokines, which have a functional role in a large number of diverse processes, including glucose and lipid homeostasis [1]. In humans, the subcutaneous and visceral adipose depots can be distinguished. Different functions are attributed to these depots, since studies have shown that the size of visceral, but not subcutaneous, adipose tissue is strongly linked to the relative risk for the development of insulin resistance and type 2 diabetes [2].

Visfatin is a recently discovered adipokine that was shown to be associated with visceral fat in humans and rodents [3]. Visfatin was also shown to mimic the effect of insulin with the same efficacy in rodent cells in vitro and in mouse models [3]. However, the following studies in human subjects reported conflicting results with regard to the association with adiposity [4-6], subcutaneous or visceral fat [4, 5, 7], and insulin resistance [5-7].

Visfatin is a rediscovery of the cytokine-like protein Pre-B-cell colony-enhancing factor 1 (PBEF $\left.{ }^{1}\right)$ [8]. It was also identified as cytosolic nicotinamide phosphoribosyltransferase (NAMPT), demonstrated by in vitro, in vivo and structural studies [9-11]. This enzyme is involved in NAD biosynthesis [10]. NAD has been established as a molecule, similar to ATP, that plays an important dual role as energy and signal transducer [12].

In view of the associations of PBEF with adipose tissue (energy storage) and NAD metabolism (energy metabolism), we wondered if the circulating level of PBEF could reflect lipid storage, especially that of visceral fat, and lipid metabolism in humans. Recently it was reported that visfatin in serum is correlated with HDL and apolipoprotein A1 in Asian Indians [13]. We have chosen to address these relation in familial combined hyperlipidemia (FCHL) families, in which the accumulation of abdominal fat, especially visceral fat, is highly prevalent [14]. To explore the link of PBEF with lipids storage and metabolism, we analyzed the relation of plasma PBEF with several parameters of adiposity, and with the plasma lipid profile in genetically predisposed relatives of FCHL families, as well as in their spouses, as a representation of the general Caucasian population.

\section{Methods}

Subjects The subjects were extracted from a large cohort of FCHL families [14], of which the members visited the Maastricht research clinic between 2003 and 2005, where the plasma samples were collected. The study protocol has been described in detail elsewhere [15]. In short, any lipid-lowering medication had been withdrawn during the last 2 weeks before blood sampling. In the group of relatives, 35 non-diabetic subjects were evenly selected from 16 unrelated families. The members from each family were limited to at most three, to avoid profound genetic influences from a single family. Among these FCHL relatives, 20 were hyperlipidemic. In the spouse group, 40 non-diabetic age- and gender- matched subjects representing the general population 
were randomly selected. The study was approved by the Medical Ethical Committee of University Hospital Maastricht, and all subjects gave written informed consent.

Anthropometrical measurements Body weight, height and body mass index (BMI) were measured in fasting state as described previously [14]. The skinfold thickness of biceps, triceps, subscapular and suprailiac regions was measured, and percentage body fat was derived from the sum of the four skinfold measurements using the method of Durnin and Womersley [16]. The size of subcutaneous adipose tissue and visceral adipose tissue were measured with an ultrasound method as described elsewhere [15].

Biochemical measurements Fasting venous blood samples were collected in precooled EDTA vacutainer tubes and immediately processed. EDTA-plasma aliquots were stored at $-80^{\circ} \mathrm{C}$ until analysis. Triglycerides, total cholesterol, HDL- and LDLcholesterol, and ApoB lipoprotein were measured as described previously [14]. PBEF was measured using a commercial enzyme immunoassay kit (Phoenix, Belmont, NY, USA), according to the manufacturer's instruction. In this assay the blood samples were 3 -fold diluted. Samples were measured in duplicate and the average was used in the data analysis.

Statistic analysis All analyses were performed with SPSS 12.0 (SPSS, Chicago, IL, USA). All values are expressed as mean \pm standard deviation. Variables significantly deviating from normal distribution were logarithmically transformed. For comparing groups, Student's $t$-test was used. The associations of circulating PBEF with other parameters were first assessed using bivariate correlation analysis by Pearson correlation coefficients. Then, for parameters of a bivariate correlation with PBEF at a significance level $<0.20$ in whole cohort, backwards multiple linear regression analysis was performed to assess the independent relation after correction for age and gender. Statistical calculations were performed in two-tail and a $p$ value $<0.05$ was considered statistically significant.

\section{Results}

Characteristics of the subjects By definition, FCHL relatives differed significantly from the spouse group with regard to plasma lipid profile, but additional differences were seen in adiposity, especially intra-abdominal (visceral) adiposity (Table 1). Both individually and combined, these two groups comprised a broad range in adiposity.

The relation between plasma PBEF level, adiposity and plasma lipid profile In the group of FCHL relatives, including both normolipidemic and hyperlipidemic subjects, plasma PBEF level was not associated with any of the adiposity indicators, including BMI, body fat percentage, sizes of subcutaneous and visceral adipose depots. However, PBEF correlated positively with HDL-cholesterol and negatively with triglycerides (Table 2). In the spouse group, plasma PBEF level showed the same correlations with 
HDL-cholesterol and triglycerides and not with any of the other parameters (Table 2 and Fig. 1).

Table 1. Anthropometric and biochemical characteristics of the FCHL families' cohort.

\begin{tabular}{|c|c|c|c|c|}
\hline & Relatives & Spouses & & \\
\hline families & 16 & 14 & & \\
\hline male/female & $15 / 20$ & $21 / 19$ & & \\
\hline age (yr) & $52.1 \pm 8.8$ & $49.1 \pm$ & 9.6 & \\
\hline BMI (kg/m2) & $30.1 \pm 4.8$ & $26.8 \pm$ & 4.2 & $* *$ \\
\hline body fat percentage & $36.5 \pm 7.7$ & $32.9 \pm$ & 7.5 & $*$ \\
\hline subcutanouse fat $(\mathrm{cm})$ & $3.2 \pm 1.2$ & $2.8 \pm$ & 1.2 & \\
\hline visceral fat $(\mathrm{cm}){ }^{1}$ & $10.0 \pm 3.1$ & $7.7 \pm$ & 2.6 & $* *$ \\
\hline total cholesterol $(\mathrm{mmol} / \mathrm{l})^{1}$ & $6.4 \pm 1.7$ & $5.2 \pm$ & 0.9 & $* *$ \\
\hline triglycerides $(\mathrm{mmol} / \mathrm{l})^{1}$ & $2.7 \pm 1.6$ & $1.4 \pm$ & 0.7 & $* *$ \\
\hline HDL-cholesterol (mmol/l) & $0.85 \pm 0.22$ & $0.97 \pm$ & 0.21 & $*$ \\
\hline 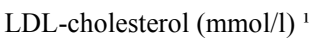 & $4.3 \pm 1.4$ & $3.6 \pm$ & 0.8 & \\
\hline $\operatorname{apoB}(\mathrm{g} / \mathrm{l})^{1}$ & $1.3 \pm 0.3$ & $1.0 \pm$ & 0.2 & $* *$ \\
\hline $\operatorname{PBEF}(\mu \mathrm{g} / \mathrm{ml})^{1}$ & $40 \pm 13$ & 38 & 12 & \\
\hline
\end{tabular}

The two groups were different with a significance $* \mathrm{p}<0.05$ or $* * \mathrm{p}<0.01$ in $\mathrm{t}$-test $\left({ }^{1}\right.$ data were log transformed in comparison).

Table 2. The correlation coefficients between PBEF ${ }^{1}$ and other variables in FCHL families' cohort

\begin{tabular}{|c|c|c|c|c|c|c|}
\hline & \multicolumn{2}{|c|}{$\begin{array}{c}\text { Relatives } \\
n=35\end{array}$} & \multicolumn{2}{|c|}{$\begin{array}{c}\text { Spouses } \\
n=40\end{array}$} & \multicolumn{2}{|c|}{$\begin{array}{c}\text { Pooled } \\
n=75\end{array}$} \\
\hline & $r$ & $p$ & $r$ & $p$ & $r$ & $p$ \\
\hline gender & -0.065 & 0.712 & -0.152 & 0.350 & -0.100 & 0.394 \\
\hline age & 0.191 & 0.273 & 0.034 & 0.836 & 0.118 & 0.312 \\
\hline$\overline{\mathrm{BMI}}$ & -0.280 & 0.103 & 0.001 & 0.995 & -0.083 & 0.479 \\
\hline body fat percentage & -0.139 & 0.426 & -0.249 & 0.121 & -0.163 & 0.162 \\
\hline subcutaneous adipose tissue size & 0.078 & 0.655 & -0.101 & 0.533 & -0.001 & 0.992 \\
\hline visceral adipose tissue size ${ }^{1}$ & -0.130 & 0.456 & -0.189 & 0.242 & -0.103 & 0.377 \\
\hline total cholesterol $^{1}$ & -0.136 & 0.436 & -0.166 & 0.307 & -0.086 & 0.465 \\
\hline triglycerides ${ }^{1}$ & -0.407 & $0.015 *$ & -0.352 & $0.026 *$ & -0.261 & $0.024 *$ \\
\hline HDL-cholesterol & 0.340 & $0.046 *$ & 0.399 & $0.011 *$ & 0.321 & $0.005 * *$ \\
\hline LDL-cholesterol $^{1}$ & -0.003 & 0.984 & -0.139 & 0.392 & -0.030 & 0.803 \\
\hline Apo $B^{1}$ & -0.020 & 0.910 & -0.305 & 0.056 & -0.111 & 0.342 \\
\hline
\end{tabular}

${ }^{1} \log$ transformed data

$* \mathrm{p}<0.05, * * \mathrm{p}<0.01$ 

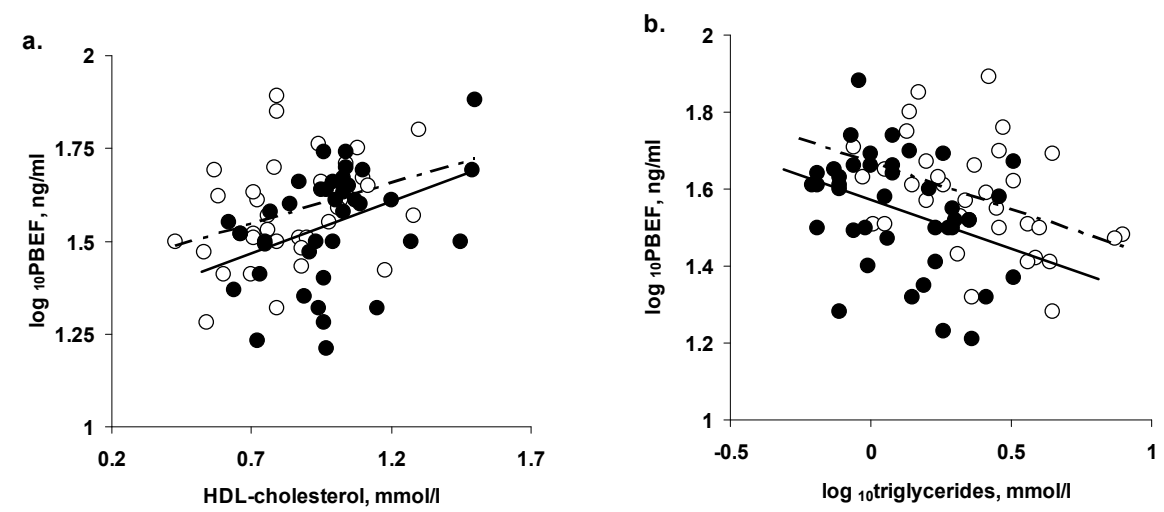

Fig. 1. Scatter plot for plasma PBEF and lipid profile (a: HDL-cholesterol, b: triglycerides) in FCHL families' cohort. Empty dots and dotted regression line: relatives; filled dots and regression line: spouses,

Because the correlations were similar in both groups, we pooled the data to increase the power in a regression model. When HDL-cholesterol, $\log _{10}$ triglycerides and body fat percentage were entered by backward stepwise method, and age, gender and group identity (spouse or relative) as a dummy variable were force-entered as independent variables into a model with $\log _{10} \mathrm{PBEF}$ as the dependent variable, multiple linear regression showed that HDL-cholesterol and triglycerides, but not body fat percentage, were independent predictors of plasma PBEF, with the standardized coefficients $\beta=$ $0.337(p=0.011)$ and $\beta=-0.301(p=0.034)$, respectively. This model $(p=0.0004)$ yielded a value of $R^{2}=0.27$, thereby explaining approximately $30 \%$ of the variance in plasma PBEF level.

\section{Discussion}

The aim of the present study was to test the link between body fat and the circulating level of PBEF. Our results showed that the circulating level of PBEF lacks correlation with static body fat indices, including BMI and visceral fat size, but relates to the beneficial high HDL/low triglyceride plasma lipid profile reflecting lipid metabolism in a non-diabetic genetically heterogeneous predisposed dyslipidemic cohort (FCHL relatives). Remarkably, these facts are also found to exist in the spouse group. This group can be regarded as representing the general Caucasian population. Although the size of the study cohorts was limited, the repeated finding corroborates that circulating PBEF has no relation with fat storage but with lipid metabolism in humans, independent of genetic background.

The significant association of circulating PBEF with HDL-cholesterol and triglycerides in Caucasians has not been reported before. In the study of Pagano et al. on Caucasians [5], the relation between PBEF and lipid profile was not directly analyzed. However, the obese group that had a significantly lower level of HDL-cholesterol and higher level of 
triglycerides, also had a significantly lower level of plasma PBEF compared to the lean group. This is in line with our findings. Chen et al. [6] did not find an association between circulating PBEF and lipid profile in Asians. However, they pooled type 2 diabetic and control subjects in the data analysis. Smith et al. recently reported that serum PBEF level correlated positively to HDL-cholesterol and apolipoproptein A1 in Asian Indians, but they could not find such a correlation in Caucasians [13]. Compared to the non-fasting samples used in their study, our results were obtained from fasting state, which is a more reproducible and better defined baseline for metabolic studies. Because of this, Smith et al. could miss the relation in Caucasians. In addition, it allowed us to detect the correlation with triglycerides. We did not measure the concentration of apolipoprotein A1. However, as the major component of HDL, apolipoprotein A1 is highly correlated with HDL-cholesterol. Together, it implies that the relation between circulating PBEF and HDL-cholesterol is universal: in Asians and in Caucasians, in hyperlipidemic subjects and in the general population.

The relation between PBEF and lipid profile may be explained in the light of the cytosolic function of PBEF as a nicotinamide phosphoribosyltransferase (NAMPT). This enzyme salvages the nicotinamide that is formed during NAD metabolism, to replenish the cellular NAD level. This pathway may have beneficial impact on aging and longevity $[11,17]$. Interestingly, it has been observed that oral administration of nicotinamide significantly increased cellular NAD level and serum HDL-cholesterol level in hemodialysis patients. The change of HDL-cholesterol correlated significantly with the change of NAD concentration in total blood cells [18]. Another NAD biosynthesis substrate, nicotinic acid, has been reported as the most potent agent for raising HDL-cholesterol [19]. Altogether, these obeservations strongly suggest that maintenance of the beneficial high HDL-cholesterol/low plasma triglycerides phenotype [20] may be associated with NAD metabolism. Our finding on the association of circulating PBEF with the plasma lipid profile implies that PBEF may serve as the link between those two processes. Presently, it is unclear how the cytosolic function of this protein is reflected in its extracellular level. It has been suggested that release of PBEF in the culture medium is most likely due to cell leakage [10]. But the significant amount of the circulating level suggests that extracellular PBEF is not merely derived from cell leakage. Therefore the source of circulating PBEF still needs to be defined.

Although the expression of PBEF in adipose tissue has been shown [3-5, 7], our data do not support the concept that adipose tissue is the main source of circulating PBEF, since no significant association was found to general adiposity indices or specific adipose tissue depots. This is conformed by studies showing PBEF is ubiquitously expressed in the body. Among different human tissues, the maximum gene expression was found in liver and peripheral blood leukocytes [8, 21]. A large-scale analysis of the human transcriptome indicated that the PBEF gene is highly expressed in whole blood, over 100 -times of the median abundance, while the expression in adipocytes is just about 2times of the median abundance (GEO series GSE1133) [22].

In mouse it was suggested that circulating PBEF plays a physiological role in lowering plasma glucose level but with a small contribution due to its low concentration, being 3$10 \%$ that of insulin [3]. In humans, the normal fasting PBEF level is $10-40 \mathrm{ng} / \mathrm{mL}$, 
which equals $180-700 \mathrm{pmol} / \mathrm{L}$ for this $55 \mathrm{kD}$ protein, 3.6-14 times the concentration of the normal fasting insulin level $(50 \mathrm{pmol} / \mathrm{L})$. If PBEF could act with the same efficacy as insulin, it should contribute importantly to the regulation of glucose metabolism. But a recent study has shown lack of association between circulating PBEF level and glucose metabolism / insulin resistance in healthy lean and obese subjects [5]. We indeed could not find such an association in the present groups either (data not shown). This suggests that circulating PBEF is not a regulator of glucose metabolism in humans.

\section{Conclusion}

Circulating PBEF is not likely a visceral fat-determined adipokine that plays a role in glucose metabolism and insulin resistance. Rather, the significant association positively with HDL-cholesterol and negatively with triglycerides suggests that circulating PBEF is an indicator of beneficial lipid metabolism, possibly linked to NAD metabolism. Further mechanistic studies in this direction may help to understand the physiological role of circulating PBEF.

Acknowledgements We thank Ms. V. Vermeulen of the Dept. Internal Medicine for the assistance in sample preparation. This study was financed by the Centre for Human Nutrigenomics in the Netherlands.

\section{References}

1. Trayhurn, P., C. Bing, and I.S. Wood, Adipose tissue and adipokines--energy regulation from the human perspective. J Nutr, 2006. 136(7 Suppl): p. 1935S-1939S.

2. Giorgino, F., L. Laviola, and J.W. Eriksson, Regional differences of insulin action in adipose tissue: insights from in vivo and in vitro studies. Acta Physiol Scand, 2005. 183(1): p. 13-30.

3. Fukuhara, A., et al., Visfatin: a protein secreted by visceral fat that mimics the effects of insulin. Science, 2005. 307(5708): p. 426-30.

4. Berndt, J., et al., Plasma visfatin concentrations and fat depot-specific mRNA expression in humans. Diabetes, 2005. 54(10): p. 2911-6.

5. Pagano, C., et al., Reduced plasma visfatin/pre-B cell colony-enhancing factor in obesity is not related to insulin resistance in humans. J Clin Endocrinol Metab, 2006. 91(8): p. 3165-70.

6. Chen, M.P., et al., Elevated plasma level of visfatin/pre-B cell colony-enhancing factor in patients with type 2 diabetes mellitus. J Clin Endocrinol Metab, 2006. 91(1): p. 295-9.

7. Varma, V., et al., Human visfatin expression: relationship to insulin sensitivity, intramyocellular lipid and inflammation. J Clin Endocrinol Metab, 2006. in press.

8. Samal, B., et al., Cloning and characterization of the cDNA encoding a novel human pre-B-cell colonyenhancing factor. Mol Cell Biol, 1994. 14(2): p. 1431-7.

9. Wang, T., et al., Structure of Nampt/PBEF/visfatin, a mammalian NAD(+) biosynthetic enzyme. Nat Struct Mol Biol, 2006. 13(7): p. 661-662.

10. Rongvaux, A., et al., Pre-B-cell colony-enhancing factor, whose expression is up-regulated in activated lymphocytes, is a nicotinamide phosphoribosyltransferase, a cytosolic enzyme involved in NAD biosynthesis. Eur J Immunol, 2002. 32(11): p. 3225-34.

11. Revollo, J.R., A.A. Grimm, and S. Imai, The NAD biosynthesis pathway mediated by nicotinamide phosphoribosyltransferase regulates Sir2 activity in mammalian cells. J Biol Chem, 2004. 279(49): p. 50754-63.

12. Ziegler, M., New functions of a long-known molecule. Emerging roles of NAD in cellular signaling. Eur J Biochem, 2000. 267(6): p. 1550-64. 
13. Smith, J., et al., Visfatin concentration in Asian Indians is correlated with high density lipoprotein cholesterol and apolipoprotein A1. Clin Endocrinol (Oxf), 2006. 65(5): p. 667-72.

14. Keulen, E.T., C. Voors-Pette, and T.W. de Bruin, Familial dyslipidemic hypertension syndrome: familial combined hyperlipidemia, and the role of abdominal fat mass. Am J Hypertens, 2001. 14(4 Pt 1): p. 35763.

15. Brouwers, M.C., et al., Fatty liver is an integral feature of familial combined hyperlipidemia: relation with fat distribution and plasma lipids. Clin Sci (Lond), 2006. in press.

16. Durnin, J.V. and J. Womersley, Body fat assessed from total body density and its estimation from skinfold thickness: measurements on 481 men and women aged from 16 to 72 years. Br J Nutr, 1974. 32(1): p. 77-97.

17. Bitterman, K.J., et al., Inhibition of silencing and accelerated aging by nicotinamide, a putative negative regulator of yeast sir2 and human SIRT1. J Biol Chem, 2002. 277(47): p. 45099-107.

18. Takahashi, Y., et al., Nicotinamide suppresses hyperphosphatemia in hemodialysis patients. Kidney Int, 2004. 65(3): p. 1099-104.

19. Chapman, M.J., et al., Raising high-density lipoprotein cholesterol with reduction of cardiovascular risk: the role of nicotinic acid--a position paper developed by the European Consensus Panel on HDL-C. Curr Med Res Opin, 2004. 20(8): p. 1253-68.

20. Linsel-Nitschke, P. and A.R. Tall, HDL as a target in the treatment of atherosclerotic cardiovascular disease. Nat Rev Drug Discov, 2005. 4(3): p. 193-205.

21. Kitani, T., S. Okuno, and H. Fujisawa, Growth phase-dependent changes in the subcellular localization of pre-B-cell colony-enhancing factor. FEBS Lett, 2003. 544(1-3): p. 74-8.

22. Su, A.I., et al., A gene atlas of the mouse and human protein-encoding transcriptomes. Proc Natl Acad Sci U S A, 2004. 101(16): p. 6062-7. 
Chapter 5. Circulating PBEF associates with lipid profile 


\section{6}

Pigment epithelium-derived factor, a potent antiangiogenic factor and newly identified adipokine, is associated with obesity, hypertension and impaired glucose metabolism in humans

E. Smit ${ }^{1}$, P. Wang ${ }^{1}$, G.H. Goossens ${ }^{1}$, M. Kruijshoop ${ }^{2}$, M.A. van Baak ${ }^{1}$, E.E. Blaak ${ }^{1}$, W.D. Boeckx ${ }^{3}$, C.J. van der Kallen ${ }^{2}$, M.M. van Greevenbroek ${ }^{2}$, E.J.M. Feskens ${ }^{4,5}$, M.C.G.J. Brouwers ${ }^{2}$, E.C.M. Mariman ${ }^{1}$

${ }^{1}$ Dept. Human Biology, Nutrition and Toxicology Research Institute Maastricht, Maastricht University, The Netherlands. ${ }^{2}$ Dept. Internal Medicine, Cardiovascular Research Institute Maastricht, Academic Hospital Maastricht and University of Maastricht, Maastricht, The Netherlands. ${ }^{3}$ Department of Plastic Surgery, Academic Hospital Maastricht, Maastricht, The Netherlands. ${ }^{4}$ Division of Human Nutrition, Wageningen University, Wageningen, The Netherlands. ${ }^{5}$ Center for Nutrition and Health, National Institute for Public Health and the Environment, Bilthoven, Netherlands

Submitted 


\begin{abstract}
Aims/hypothesis Adipose tissue releases factors (adipokines) that influence local, peripheral as well as central processes. In the present study we determined the relationship between plasma concentration of the recently identified adipokine PEDF and human obesity, specific adipose tissue depots, glucose metabolism and blood pressure.

Methods Plasma PEDF was measured in 33 male subjects (study 1, BMI 20-33 kg/m²) and 84 male / 63 female subjects (study 2, BMI 30-40 kg/m²), respectively, by ELISA. Blood pressure, lipid profile, glucose, insulin measurements were performed as well as standard anthropometry including measurement of various adipose tissue depots

Results Plasma PEDF concentration correlated strongly with BMI $(p<.001)$, visceral adipose tissue $(p=.001)$ as well as triglycerides $(p=.035)$ and fasting insulin $(p=$ 0.048 ) in our first study population. Interestingly, in class I obese and class II obese subjects plasma PEDF concentrations were largely independent of BMI, but were higher in hypertensive compared normotensive subjects $(p=.002)$. This relationship was especially evident in male impaired glucose tolerant (IGT) and type 2 diabetic (T2DM) subjects ( $p=.038$ and $p=.008$, respectively) and female T2DM $(p=.002)$ subjects.

Conclusions/interpretation We observed that increased circulating levels of PEDF are positively associated with BMI, the size of the visceral fat depot and insulin concentration in NGT normal to early class I obese males. Furthermore, circulating PEDF levels are elevated in hypertensive versus normotensive obese IGT male and T2DM male and female subjects and as such could play a role in the etiology of hypertension and cardiovascular complications in these subjects.
\end{abstract}

\title{
Keywords
}

Pigment epithelium-derived factor, adipokine, hypertension, impaired glucose tolerance, type 2 diabetes, visceral fat, insulin resistance

\section{Abbreviations}

PEDF: pigment epithelium-derived factor; FBG: fasting blood glucose; NFG: normal fasting glucose; T2DM: type 2 diabetes mellitus; HOMA-IR: Homeostasis Model Assessment of Insulin Resistance; SBP: systolic blood pressure; DBP: diastolic blood pressure; NT: normotensive; HT: hypertensive 


\section{Introduction}

Obesity is a major health problem worldwide. Due to a dramatic increase in the incidence of obesity in western societies over the years, the incidence of obesityassociated diseases such as type 2 diabetes mellitus (T2DM), cardiovascular disease and cancer has also increased [1,2]. In recent years adipose tissue has been increasingly recognized as an important secretory organ that releases factors influencing local, peripheral as well as central processes [3]. These factors, called adipokines, include for example leptin and adiponectin which play a role in glucose and lipid metabolism, but also pro-inflammatory cytokines such as interleukin 6 and tumor necrosis factor alpha [4]. Therefore adipokines may play a role in development of obesity-related diseases. Recent proteomic studies have identified a number of novel proteins secreted by preadipocytes and adipocytes in vitro $[5,6]$. Among these proteins was pigment epithelium-derived factor (PEDF).

The PEDF protein was originally identified in retinal cell culture supernatant and characterized as a neurotrophic factor [7]. In addition, there are various lines of evidence that PEDF possesses anti-oxidative properties as well as anti-angiogenic and anti-vasopermeability properties [8-11]. With respect to the anti-angiogenic and antivasopermeability activity of PEDF it is thought to function antagonistically to vascular endothelial growth factor (VEGF) [11]. Substantial evidence suggests that PEDF plays a role in the development of diabetic retinopathy in animals and humans [12], but relatively little is know about PEDF function outside the boundaries of the eye. The PEDF gene is highly expressed in adipose tissue in mice and adipose tissue, liver and bone marrow in humans [13-15]. Interestingly, PEDF protein has been detected in (human) plasma at a physiologically relevant concentration, suggesting that PEDF may affect angiogenesis/vascular permeability or neurotrophic/processes throughout the human body [16].

Since murine 3T3-L1 adipocytes secrete PEDF [5] we hypothesized that, if this is also true for human adipocytes in vivo, the amount of body fat could be an important determinant of circulating PEDF concentration. We performed two cross-sectional studies, the first in male NGT normal weight to early class I obese subjects with a BMI varying from 20 to $33 \mathrm{~kg} / \mathrm{m}^{2}$ and the second in male and female NGT, IGT or T2DM subjects with a BMI ranging from 30 to $40 \mathrm{~kg} / \mathrm{m}^{2}$. Our aim was to determine the relationship of plasma PEDF with obesity, obesity-related hypertension and impaired glucose metabolism in humans.

\section{Subjects, materials and methods}

Study design We performed two separate cross-sectional studies in Caucasian males and females. For both studies the participants were asked to come to the laboratory after an overnight fast and to refrain from smoking, drinking alcohol and doing strenuous exercise for a period of $24 \mathrm{~h}$ prior to the study. The study protocols were approved by the Medical Ethics Committee of Maastricht Academic Hospital and the clinical investigations were performed according to the Declaration of Helsinki. All subjects gave informed consent for participation in these studies. WHO criteria for BMI were 
used to classify normal weight versus pre-obes and obese subjects, WHO criteria for 2 hour (2h) glucose concentrations were used to classify subjects as NGT, IGT or T2DM and WHO criteria for blood pressure were used to classify normotension (NT) and hypertension (HT) $[17,18,19]$.

Study 1 Thirty-two male subjects (spouse controls) with a continuous BMI range of 20 to $33 \mathrm{~kg} / \mathrm{m}^{2}$ were selected from Familial Combined Hyperlipidemia (FCHL) study performed in Maastricht [20]. Subject characteristics summarized in table 1. The subjects in this study were extensively characterized for body fat distribution with specific attention for the subcutaneous and abdominal depots, as described below.

Study 2 Eighty-four male and sixty-three female obese subjects with a continuous BMI range of 30 to $40 \mathrm{~kg} / \mathrm{m}^{2}$ were selected from the Cohort study Diabetes and Atherosclerosis Maastricht (CODAM) [21]. Subject characteristics are summarized in table 1. This study was performed with special attention for the impact of BMI, blood pressure and glucose metabolism on plasma PEDF concentrations. We analyzed both male and female subjects to determine whether there is a gender-specific difference in plasma PEDF levels.

Anthropometric measurements Body mass index (BMI) was calculated by dividing body weight $(\mathrm{kg})$ by height $(\mathrm{m})$ squared. Hip circumference was determined in standing position at the level of the trochanter major. Biceps, triceps, subscapular and suprailiacal skinfold thickness ( $\mathrm{mm}$ ) was measured with a plastic caliper on the nondominant side. Waist circumference and sagittal diameter were measured in supine position at the level midway between the iliacal crest and lowest rib at the end of a normal expiration. Sagittal diameter was measured with a sliding beam caliper. Waistto-hip ratio (WHR) was calculated as the ratio between waist and hip circumference.

Ultrasound Subcutaneous and visceral adipose tissue was measured with an ATL 9 HDI ultrasound system (Bothell, WA, USA) at the same level as waist circumference and sagittal diameter. Subcutaneous fat was determined in the midline in transverse direction with a L5-10 transducer and was defined as the distance between skin and linea alba. The average of two measurements was taken for analysis. The novel accurate quantitative measurement of visceral (or intra-abdominal) fat was performed as described by Stolk et al. [22]. Briefly, using a C4-2 transducer, the distance between peritoneum and the anterior part of vertebral body was measured in a sagittal direction at three sites: at midline, and $10 \mathrm{~cm}$ to left and right from the midline, respectively. All distances were measured twice and the average of each of the three sites was used to calculate the average visceral fat depot. These measurements were done with minimal pressure exerted on the probe and at the end of a normal expiration.

Biochemical analysis Venous blood was collected using a vacutainer system and EDTA as anti-coagulant. Plasma was separated from cells by centrifugation (10 min, 
$1.000 \times \mathrm{g}, 4^{\circ} \mathrm{C}$ ), frozen in liquid nitrogen and stored in aliquots at $-80^{\circ} \mathrm{C}$ until analysis. Plasma free fatty acids, triglycerides, HDL- and LDL-cholesterol were determined as described by Keulen et al. 2002 [20]. PEDF was quantified by ELISA (Chemikon, Temecula, CA, USA; assay sensitivity: $0.9 \mathrm{ng} / \mathrm{mL}$; range of detection $0.9 \mathrm{ng} / \mathrm{mL}$ to 62.5 $\mathrm{ng} / \mathrm{mL}$, intra-assay variation around $5.3 \%$ and inter-assay variation around $16.0 \%$ ). Since PEDF protein strongly associates with other plasma proteins, which may interfere with quantification of total plasma PEDF protein, plasma was treated with urea $(8 \mathrm{~mol} / \mathrm{L}$ final concentration) for $60 \mathrm{~min}$ on ice, diluted 400 times in dilution buffer and applied to the ELISA plate (as recommended by the manufacturer). Insulin concentrations were determined using an ELISA (study 1) from Mercodia (Uppsala, Sweden) or with a twosided immunoradiometric assay (study 2) in the Endocrinological laboratory, University Hospital Free University, Amsterdam, The Netherlands using monoclonal antibodies (Medgenix Diagnostics, Fleurus, Belgium). Fasting blood glucose (FBG) was determined using the hexokinase enzymatic assay (ABX Diagnostics, Montpellier, France) and a Cobas Fara centrifugal analyzer. Homeostasis model assessment (HOMA-IR) was calculated as a measure of insulin resistance (formula: insulin x FBG / 22.5).

Statistical analysis Data outliers were removed from analyses when Cook's distance was $>1$. Variables significantly deviating from normal distribution were log transformed. Parametric data were analyzed using Student's $t$-test for comparison of groups and Pearson ( $r$, standard age-corrected) correlation coefficient for analysis of bivariate relationships. Non-parametric data were analyzed using Wilcoxon's Rank Sum test and Spearman's $\rho\left(r_{s}\right)$ correlation coefficient, respectively. Multivariate linear regression analysis was performed using only those variables that were univariately related to dependent variable PEDF at the $p<.150$ significance level. Statistical analyses were performed with SPSS for Windows version 12 (SPSS Inc., Chicago, IL, USA). Data is presented as mean \pm SEM. Statistical calculations were performed twotailed and a $p$-value $<0.05$ was considered statistically significant.

\section{Results}

Plasma PEDF levels in normal weight and class I obese male subjects In this study thirty-two NGT individuals with a BMI ranging from 20 to $33 \mathrm{~kg} / \mathrm{m}^{2}$ participated who were extensively characterized for body fat distribution. All subjects had a normal glucose tolerance and blood pressure according to WHO criteria. Relationships were found between plasma PEDF levels and BMI $(r=.676, p<.001$; figure 1A), a descriptor of total body adiposity, and various descriptors of abdominal adiposity such as waist circumference $(r=.534, p=.003)$ and sagittal diameter $(r=.581, p=.001)$. In addition, PEDF concentrations correlated strongly with size of the visceral fat depot $(r$ $=.576, p=.001$; figure $1 \mathrm{~B}$ ) as measured by ultrasound. No significant correlation was found between PEDF level and abdominal subcutaneous fat $(p=.881$; figure 1C) or subcutaneous fat determined for various locations around the body (biceps, $p=.841$; triceps, $p=.383$; subscapular, $p=.352$; suprailiacal, $p=.202$, not shown). Finally, 
plasma PEDF was positively correlated with plasma triglyceride $\left(r_{s}=.380, p=.035\right)$ and fasting insulin $\left(r_{s}=.370, p=0.048\right)$, but not FBG concentration $(p=.256)$.

Multiple linear regression analyses using the abdominal subcutaneous and visceral fat as input variables showed that only visceral fat is a significant predictor for plasma PEDF level. With the final model we constructed, $43 \%$ of the observed variance in plasma PEDF level could be explained (table 2). Results were similar when multiple regression analysis was performed with visceral fat and non-abdominal subcutaneous fat depots (not shown).

Plasma PEDF levels in class I and class II obese male and female subjects This study was performed in males and females with a BMI ranging from 30 to $40 \mathrm{~kg} / \mathrm{m}^{2}$ and included subjects with NGT, IGT or T2DM. According to WHO criteria twenty male and twenty-nine female subjects had NGT, twenty-two males and twelve females had IGT and forty-two males and twenty-two females had T2DM.

\section{- Male}

In the male group $(n=84)$ PEDF correlated positively with $\operatorname{SBP}(r=.255, p=.025)$. A non-significant relationship was observed between PEDF and insulin concentration $\left(r_{s}\right.$ $=.189, p=.084)$, which, upon separation into NGT, IGT and T2DM, was found to be strongest in IGT subjects $\left(r_{s}=.611, p=.003\right)$, less so in NGT $\left(r_{\mathrm{s}}=.434, p=.056\right)$ subjects and absent in subjects with T2DM $(p=.382)$. Plasma PEDF did not correlate with BMI $(p=.848)$, WHR $(p=.498)$, sagittal diameter $(p=.401)$ or FBG concentration $(p=.136)$.

We found significantly decreased plasma PEDF concentrations in class II obese NGT subjects compared to class I obese NGT male subjects $(p=.001)$. In contrast, we observed equal or higher plasma PEDF level in class II obese compared to class I obese IGT and T2DM subjects (figure 2A). T2DM patients had the highest mean plasma PEDF concentration of the NGT, IGT and T2DM categories.

Since a positive correlation was found between plasma PEDF and SBP we analyzed the relationship of plasma PEDF with hypertension. Comparison of normotensive (NT) with hypertensive (HT) subjects in this cohort showed a significantly higher PEDF level in HT subjects $(p=.002$; figure $3 \mathrm{~A})$. Following this analysis we subdivided the NT and HT male subjects into NGT, IGT and T2DM categories. From this we observed that PEDF levels were comparable between NT and HT subjects with NGT while for IGT or T2DM subjects PEDF level was clearly higher in those subjects with HT ( $p=.038$ and $p=.008$, respectively) as is shown in figure $3 \mathrm{~B}$.

\section{- Female}

In contrast to the male group no significant correlations were found between plasma PEDF concentration and any of the measured variables including SBP. Plasma PEDF concentrations of class I and class II obese NGT, IGT and T2DM female subjects did not differ significantly. However, plasma PEDF concentrations tend to be highest in 
class II obese T2DM female subjects (figure 2B), as was observed for the male subjects. In contrast to male subjects significantly increased plasma PEDF was not observed in HT compared to NT female subjects (figure 3A). Comparison of NT with HT NGT, IGT and T2DM female subjects showed that for NGT and IGT subjects PEDF concentrations were similar but were significantly lower in NT compared to HT T2DM subjects $(p=.002$; figure $3 \mathrm{C})$.

Table 1. Subject characteristics.

\begin{tabular}{|c|c|c|c|}
\hline \multirow{2}{*}{$\begin{array}{l}\text { Characteristic } \\
\text { Gender }\end{array}$} & \multirow{2}{*}{$\frac{\text { Study } 1}{\mathrm{~m}}$} & \multicolumn{2}{|c|}{ Study 2} \\
\hline & & $\mathrm{m}$ & $\mathrm{f}$ \\
\hline Subjects (n) & 32 & 84 & 63 \\
\hline Age (yr) & $53.6 \pm 2.5$ & $59.1 \pm 0.72$ & $59.7 \pm 0.9$ \\
\hline BMI (kg/m2) & $25.9 \pm 0.6$ & $32.9 \pm 0.32$ & $33.8 \pm 0.4$ \\
\hline Waist (cm) & $95.4 \pm 1.6$ & $113.6 \pm 0.89$ & $104.9 \pm 2.0$ \\
\hline Hip (cm) & $99.5 \pm 1.0$ & $109.9 \pm 0.79$ & $113.5 \pm 2.0$ \\
\hline WHR & $0.96 \pm 0.12$ & $1.03 \pm 0.01$ & $0.93 \pm 0.1$ \\
\hline $\mathrm{FBG}(\mathrm{mmol} / \mathrm{l})$ & $5.08 \pm 0.07$ & $7.07 \pm 0.22$ & $6.33 \pm 0.24$ \\
\hline Insulin (mU/1) & $5.92 \pm 0.80$ & $17.51 \pm 1.07$ & $13.21 \pm 0.79$ \\
\hline HOMA-IR & $1.36 \pm 0.19$ & $5.87 \pm 0.57$ & $3.95 \pm 0.36$ \\
\hline $\mathrm{DBP}(\mathrm{mm} \mathrm{Hg})$ & $85 \pm 2$ & $87 \pm 1$ & $83 \pm 1$ \\
\hline SBP (mm Hg) & $138 \pm 3$ & $146 \pm 2$ & $144 \pm 3$ \\
\hline
\end{tabular}

Values are means \pm SEM; m, male; f, female; BMI, Body Mass Index; FBG, Fasting Blood Glucose; WHR, Waist-to-Hip Ratio; HOMA-IR, Homeostasis Model Assessment of Insulin Resistance; DBP, Diastolic Blood Pressure; SBP, Systolic Blood Pressure.

Table 2. Linear regression models predicting of plasma PEDF level in lean to overweight obese male individuals (study 1 ).

\begin{tabular}{lcccccc}
\hline Model & $\beta$ & SE $B$ & St $\beta$ & $95 \%$ CI & $\begin{array}{l}p \text {-value } \\
\text { model }\end{array}$ & $\begin{array}{l}R^{2} \\
\text { model }\end{array}$ \\
\hline $\begin{array}{l}\text { Univariate } \\
\text { Visceral fat }\end{array}$ & 479.0 & 116.0 & .60 & $242.0-716.0$ & $<.001$ & .36 \\
\hline $\begin{array}{l}\text { Multivariate, model 1 } \\
\text { Visceral fat }\end{array}$ & 449.5 & 127.6 & .57 & $188.4-710.5$ & .001 & .37 \\
\hline $\begin{array}{l}\text { Multivariate, model 2 } \\
\text { Visceral fat }\end{array}$ & 352.6 & 166.6 & .44 & $7.8-697.3$ & .010 & .43 \\
\hline
\end{tabular}

Dependent variable PEDF; St, Standardized; SE, standard error; CI, confidence interval;

${ }^{a}$ adjusted for age; ${ }^{b}$ adjusted for age, fasting insulin and fasting glucose 
A.

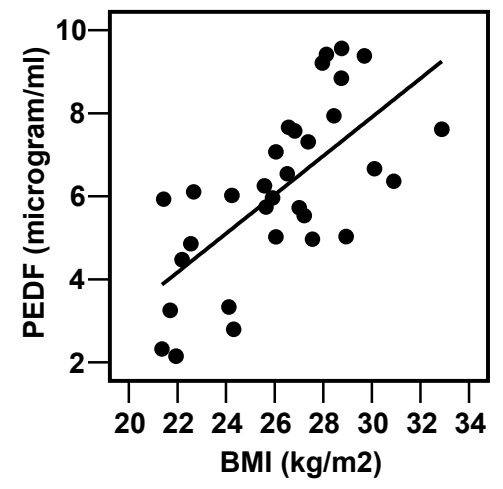

C.

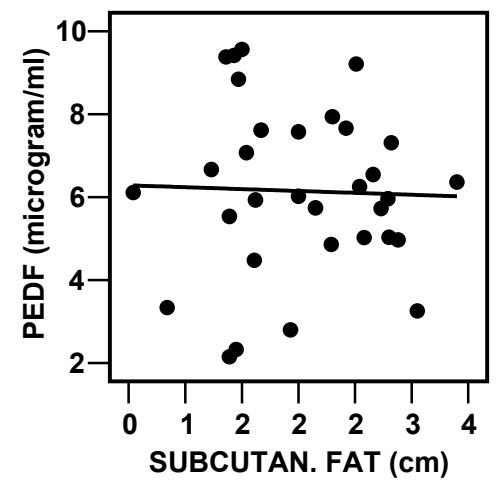

B.

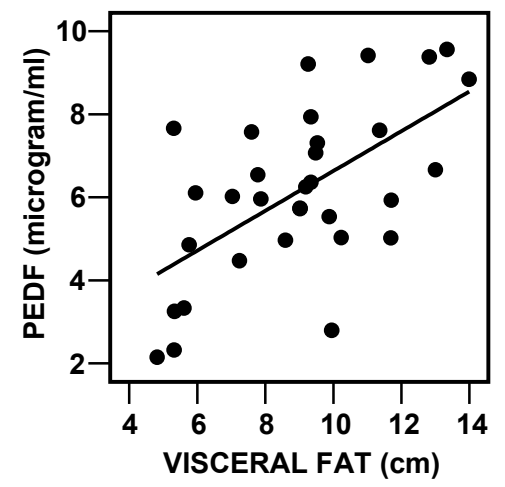

Fig.1. Plasma PEDF in males (study 1) (A) Relationship of plasma PEDF with BMI $(r=.676$, $p<.001)$, (B) visceral fat $(r=.576, p<.001)$, (C) abdominal subcutaneous fat $(r=-.057, p=.881)$. Solid line, linear regression curve fit. 
A.

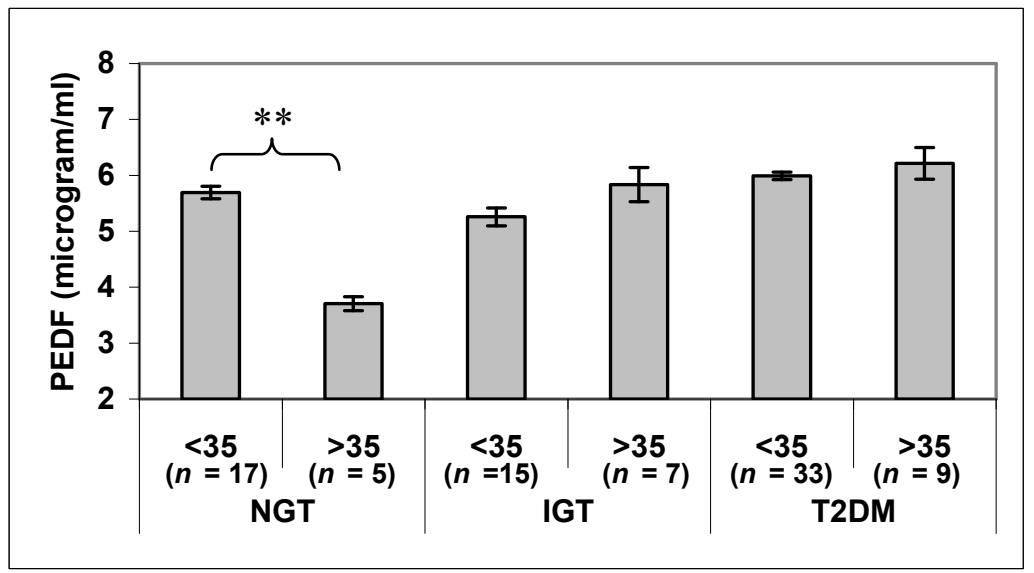

B.

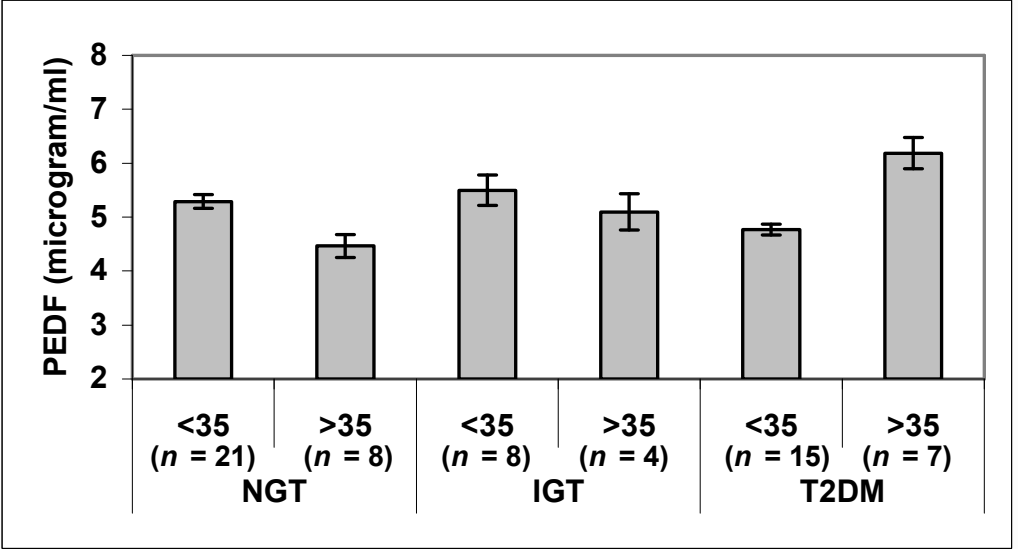

Fig. 2. Plasma PEDF in obese (BMI $30-35 \mathrm{~kg} / \mathrm{m}^{2}$ ) and class II obese (BMI $35-40 \mathrm{~kg} / \mathrm{m}^{2}$ ) males and females and the relationship with NGT, IGT or T2DM (study 2). (A) male subjects ; NGT class I obese $v s$. NGT class II obese, $p=.001$; IGT class I obese $v s$. IGT class II obese, not significant (ns); T2DM class I obese $v s$. T2DM class II obese, $n s$; (B) females; NGT class I obese $v s$. NGT class II obese, $n \mathrm{~s}$; IGT class I obese $v s$. IGT class II obese, $n s ;$ T2DM class I obese $v s$. T2DM class II obese, $n s .{ }^{* *}, p=.001 ;<35$, class I obese; $>35$, class II obese. 
A

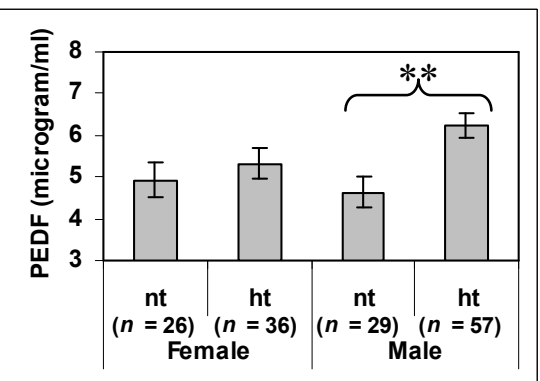

B

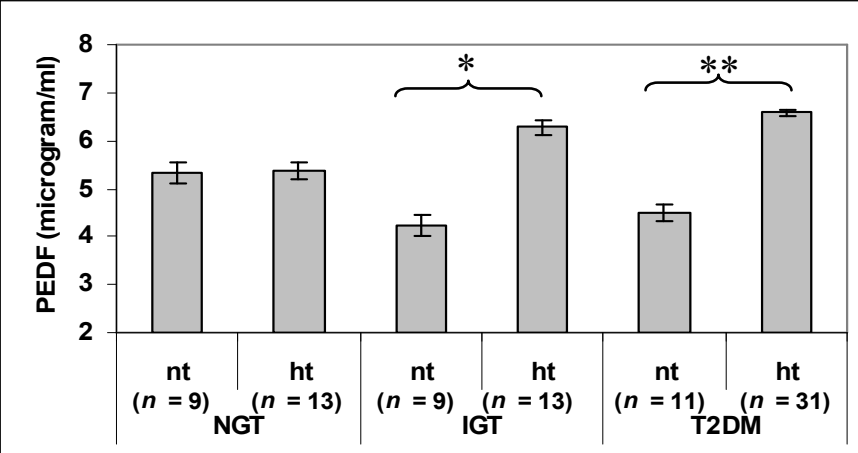

C

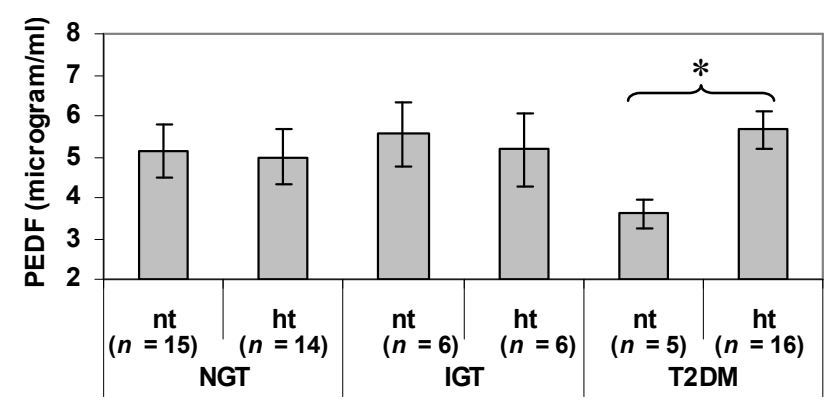

Fig. 3. Plasma PEDF in male and female subjects and the relationship with normo- and hypertension (study 2). (A) Plasma PEDF in normotensive (nt) vs. hypertensive (ht) female subjects, $n s$; nt $v s$. ht male subjects, $p=.002$; (B) Plasma PEDF in nt $v s$. ht male NGT, IGT and T2DM subjects. NGT nt $v s$. NGT ht, $n s$; IGT nt $v s$. IGT ht subjects, $p=.038$; T2DM nt $v s$. T2DM ht, $p=.008$; (C) Plasma PEDF in nt and ht female NGT, IGT and T2DM subjects. NGT nt $v s$. NGT ht, $n s$; IGT nt $v s$. IGT ht, $n s ;$ T2DM nt $v s$. T2DM ht, $p=.002$. 


\section{Discussion}

Pigment epithelium-derived factor (PEDF) was recently identified and as an adipocyte secretory protein (or adipokine) from murine adipocytes in vitro in our laboratory [5] and confirmed by others in human adipocytes in vitro [23]. Since PEDF is also highly expressed in human adipose tissue [15], we hypothesized that plasma PEDF concentration could be increased in human obesity. To investigate this we performed two human cohort studies that are, to our knowledge, the first cohort study to report plasma PEDF concentrations in vivo in humans. Our work confirms biochemical data from Petersen et al. [16], that PEDF is present in the circulation at an average concentration of $5 \mu \mathrm{g} / \mathrm{ml}$ in both males and females. More interestingly, the studies show that plasma PEDF concentration is positively related with total body fat in lean to early class I obese male subjects (study 1) and with impaired glucose metabolism and blood pressure in obese male and female subjects (study 2).

In study 1 we observed that an increased abdominal fat mass is strongly associated with an increased circulating PEDF concentration in male subjects suggesting that this adipose tissue depot may be directly or indirectly involved in increasing circulating PEDF concentration. In other words, PEDF may be secreted into the circulation directly from the intra-abdominal adipose tissue or, alternatively, other factors derived from this tissue could stimulate PEDF secretion by tissues such as liver, in which PEDF is also highly expressed.

Since obesity, particularly visceral obesity, is associated with insulin resistance [24], that may ultimately lead to development of type 2 diabetes mellitus (T2DM), we examined the associations of plasma PEDF concentration with fasting insulin and glucose levels. Study 1 did not reveal a relationship with FBG since all subjects had normal fasting glucose levels, but we did find a positive relationship between plasma PEDF and insulin resistance in these subjects. This finding indicates that insulin could have a role in stimulating PEDF expression.

In study 2 we observed that in obese NGT, non-insulin resistant, subjects an increasing class II obese subjects have decreased plasma PEDF levels, a phenomenon that was not observed for the IGT and T2DM subjects. This effect was significant in males but in females only a tendency was observed. This suggests that in obese NGT subjects there may be a certain threshold BMI above which plasma PEDF concentration decreases again. This effect may be due to a counter-regulatory response in class II obese NGT subjects, down-regulating PEDF production. However, when glucose metabolism becomes disturbed (when an individual progresses from NGT to IGT and finally overt T2DM) this down-regulation is abolished (or masked by a stronger effect of impaired glucose metabolism). From our results it is difficult to determine which molecular mechanisms underlie this dual response, but again insulin resistance could be an important determinant in this case.

In addition to a relationship with disturbances in glucose metabolism, we found that obese hypertensive (HT) male subjects have a significantly increased plasma PEDF concentration compared to normotensive (NT) subjects. In obese females a similar, but not significant, increase was observed. This finding indicates a possible role for PEDF, 
as a factor that has been demonstrated to negatively influence angiogenesis and vasopermeability $[10,11]$, in the development of hypertension. This is especially relevant for subjects with IGT and T2DM. We already demonstrated that PEDF is positively related to impaired glucose metabolism and further analyses showed that the increased PEDF concentration in HT subjects is mainly present in subjects with IGT or T2DM.

It has previously been recognized that subjects with IGT and T2DM have an increased risk for development of hypertension [25] and our data also point to a relationship between presence of IGT or T2DM and hypertension in obese subjects. Thus, one could speculate whether an anti-angiogenic factor such as PEDF could be directly involved in the development of hypertension in subjects with an impaired glucose metabolism by negatively influencing angiogenesis or vasopermeability in the vascular system throughout the body.

With respect to the effect of gender on plasma PEDF levels the following can be said. Overall plasma PEDF concentrations do not differ between males and females. We find significant effects of various parameters on plasma PEDF concentrations in the obese male study population, whereas these effects are less significant or tend to significance in the female population. The lower significance of these effects is probably due to greater variation in the female data. We do however observe a clear similarity between male and female data (with respect to blood pressure for example) and at this time have no reason to suspect that a gender-specific difference in regulation of plasma PEDF concentration exists.

\section{Conclusion}

Our data showed that circulation level of PEDF does positively correlate with fat, especially with visceral fat. This warrants the further studies on its role in obesity and visceral fat related disorders. Its association with hypertension and/or impaired glucose tolerance in obese people suggests that PEDF could play a role in the etiology of hypertension and cardiovascular disease (complications) in obese IGT and T2DM subjects.

\section{References}

1. Caballero AE (2003) Endothelial dysfunction in obesity and insulin resistance: a road to diabetes and heart disease. Obes Res 11:1278-1289

2. Calle EE, Rodriguez C, Walker-Thurmond K, Thun MJ (2003) Overweight, obesity, and mortality from cancer in a prospectively studied cohort of U.S. adults. N Engl J Med 348:1625-1638

3. Mohamed-Ali V, Pinkney JH, Coppack SW (1998) Adipose tissue as an endocrine and paracrine organ. Int J Obes Relat Metab Disord 22:1145-1158

4. Havel PJ (2004) Update on adipocyte hormones: regulation of energy balance and carbohydrate/lipid metabolism. Diabetes 53 Suppl 1:S143-151

5. Wang P, Mariman E, Keijer J et al. (2004) Profiling of the secreted proteins during 3T3-L1 adipocyte differentiation leads to the identification of novel adipokines. Cell Mol Life Sci 61:2405-2417 
6. Kratchmarova I, Kalume DE, Blagoev B et al. (2002) A proteomic approach for identification of secreted proteins during the differentiation of 3T3-L1 preadipocytes to adipocytes. Mol Cell Proteomics 1:213-222, 2002

7. Tombran-Tink J, Chader GG, Johnson LV (1991) PEDF: a pigment epithelium-derived factor with potent neuronal differentiative activity. Exp Eye Res.53(3):411-414.

8. Yamagishi S, Inagaki Y, Amano S, Okamoto T, Takeuchi M and Makita Z (2002) Pigment epitheliumderived factor protects cultured retinal pericytes from advanced glycation end product-induced injury through its antioxidative properties. Biochem Biophys Res Commun. 296:877-882

9. Yamagishi S, Inagaki Y, Nakamura K et al. (2004) Pigment epithelium-derived factor inhibits TNF-ainduced interleukin-6 expression in endothelial cells by suppressing NADPH oxidase-mediated reactive oxygen species generation. J Mol Cell Cardiol 37: 497-506

10. Dawson DW, Volpert OV, Gillis P et al. (1999) Pigment epithelium-derived factor: a potent inhibitor of angiogenesis. Science 285:245-248

11. Liu H, Ren J-G, Cooper WL, Hawkins CE, Cowan MR, and Tong PY (2004) Identification of the antivasopermeability effect of pigment epithelium-derived factor and its active site. Proc Natl Acad Sci U S A 101: 6605-6610

12. Chader GJ (2005) Surmountable challenges in translating pigment epithelium-derived factor (PEDF) therapy from animal models to clinical trials for retinal degenerations.Retina. 25:S29-S30

13. Su AI, Wiltshire T, Batalov S et al. (2004) A gene atlas of the mouse and human protein-encoding transcriptomes. Proc Natl Acad Sci U S A 101:6062-6067

14. Genomics Institute of the Novartis Research Foundation (2003) Symatlas. URL: http://symatlas.gnf.org. Search SerpinF1 in mouse and human databases.

15. Maeda K, Okubo K, Shimomura I, et al. (1997) Analysis of an expression profile of genes in the human adipose tissue. Gene 190 (2): 227-235

16. Petersen SV, Valnickova Z, Enghild JJ (2003) Pigment-epithelium-derived factor (PEDF) occurs at a physiologically relevant concentration in human blood: purification and characterization. Biochem $\mathrm{J}$ 374:199-206

17. World Health Organization (1995) Physical status: the use and interpretation of anthropometry. Report of a WHO Expert Committee. WHO Technical Report Series 854. WHO, Geneva, Switzerland

18. World Health Organization (1999) Definition, diagnosis and classification of diabetes mellitus. Report of a WHO consultation. Part 1: Diagnosis and Classification of Diabetes Mellitus. WHO, Geneva, Switzerland

19. World Health Organization-International Society of Hypertension (1999) Guidelines for the Management of Hypertension. J Hypertens. 17(2):151-183

20. Keulen ET, Kruijshoop M, Schaper NC, Hoeks AP, de Bruin TW (2002) Increased intima-media thickness in familial combined hyperlipidemia associated with apolipoprotein B. Arterioscler Thromb Vasc Biol 22:283-288

21. Kruijshoop M, Feskens EJ, Blaak EE, de Bruin TW (2004) Validation of capillary glucose measurements to detect glucose intolerance or type 2 diabetes mellitus in the general population. Clin Chim Acta 341(12):33-40.

22. Stolk RP, Wink O, Zelissen PM, Meijer R, van Gils AP, Grobbee DE (2001) Validity and reproducibility of ultrasonography for the measurement of intra-abdominal adipose tissue. Int J Obes Relat Metab Disord. 25(9):1346-1351.

23. Zvonic S, Lefevre M, Kilroy G, et al. (2006) Secretome of primary cultures of human adipose-derived stem cells (ASCs): modulation of serpins by adipogenesis. Mol Cell Proteomics. In press

24. Despres JP. (2001) Health consequences of visceral obesity. Ann. Med. 33(8):534-541

25. Cooper ME, Johnston CI. (2000) Optimizing treatment of hypertension in patients with diabetes. 283(24):3177-3179 
Chapter 6. Plasma PEDF is elevated in human obesity 


\section{General Discussion}

P. Wang ${ }^{1,2}$

${ }^{1}$ Maastricht Proteomics Center, Department of Human Biology, the Nutrition and Toxicology Research Institute Maastricht (NUTRIM), Maastricht University, Maastricht, the Netherlands. ${ }^{2}$ Food Bioactives Group, RIKILT-Institute of Food Safety, Wageningen, the Netherlands. 


\section{Contents}

How to understand the cell through a systems biology approach? 112

How useful is the 3T3-L1 cell line as an adipocyte model? 116

What is the role of the secretory function in the physiology of adipose tissue?.. 119

\section{How to understand the cell through a systems biology approach?}

Although functional genomics is intended to annotate the functions of all genes in the genome of an organism [1], life is not easily expressed in simple cause and effect relationships. With the power to delete, replace, modify and control individual genes, came the realization that a single perturbation could either produce many effects simultaneously, ranging from the subtle to the disastrous, or, more frequently, resulted in no effect at all. This is due to the robustness and resilience of biological systems [2]. It has long been recognised that the ability to maintain the performance in the face of perturbation and uncertainty is strongly favoured by evolution, and is the key property of all biological systems [3]. This defines the challenge of understanding biological systems at a system level: complex networks with molecular interactions that operate hierarchically or in parallel. The exact meaning of the term 'systems biology' is not yet clearly defined, but it is generally agreed that it has something to do with a quantitative description of life, using the rapidly growing body of transcriptomic, proteomic and metabolomic ('omics') data to generate a holistic, comprehensive and unbiased view of the biological system, presently at a cellular level [2, 4-6]. Compared with traditional physiology, systems biology is distinct in its quantitative molecular basis [7].

A biological system cannot be understood fully by merely assembling genes, proteins with their interactions, although such a level of functional genomic understanding is the first step to approach real life [8]. The question is, how we come to an understanding? With regard to the key properties of robustness [3] and modularity [9], biological systems and complicated mechanical systems show interesting similarity. The view of a well-understood designed machine offers a powerful perspective on the littleunderstood biological system. This concept can be dated back to almost 60 years ago when scientists realised that the communication and control in living organisms is comparable to that of the machine $[8,10]$. From this point of view, cellular process can be studied analogously to an electronic circuit [9]. The functional units in the cell can be classified as feedback loops, switches, timers, oscillators and amplifiers. After logical and informational processing, these modules can perform cellular activities such as communications, homeostasis, spatial and temporal organization, reproduction and adaptation to stimuli. Finally we are able to predict what a cell can do by simply knowing what module is present and in which way they are connected. In the author's view, a quantitative assembling of 'omics' data in dynamic functional modules is the way to approach systems biology. 
Practical questions arise in assembling, or integrating, 'omics' data. At this stage, most work has been done at the transcriptome and proteome level. It is already noted that mRNA changes do not necessary reflect protein changes, as we showed in Chapter 3 and 4 . A number of reasons are listed as below.

First, technical aspects cannot be neglected in pursuing a systems description. In our research, 2D gel spots with silver staining were used to detect protein abundance, and aligned micro spots of fluorescence-labelled cDNA were used to detect mRNA abundance. In general, it can be stated that different detection sensitivity in proteomic and microarray techniques generate a much smaller size of proteomic data compared to transcriptomic data, which does not allow a complete match anyway. And overall, the resolution and accuracy of the 2D gel assay is less than that of DNA microarray assay. The quantification of protein spots on the gel can be affected by non-uniform spots size, and also by the possible co-presence of more proteins in that spot. The dynamic range of silver staining is small compared to fluorescence dyes. Our probes on the DNA microarray did not take the alternative splicing into account, while on 2D gel, different isoforms of proteins were visible. However, these technical drawbacks are possible to overcome. With regard to different expression products resulting from one gene, newly launched microarrays by Affymetrix (tiled probes) and Agilent (probes representing different mRNAs) offer the opportunity to gain insight into splice events. For proteomics, quantitative 2D LC-MS/MS can be a good solution. It offers a high sensitivity, a high resolution, a broad dynamic range and high-speed throughout [11]. When the data processing algorithm combines all the peptide peaks of the same protein as one output, the total amount of the protein can be more easily correlated to total amount of mRNA. However, in this way the information on the pattern of different protein isoforms will be missed.

Second, the changes in gene expression and protein levels may follow different sequential waves $[12,13]$. In acute studies, protein synthesis may lag behind mRNA synthesis. On the other hand, in long-term studies, gene expression differences may already return to basal levels when protein levels are still altered. A possible solution to get insights of such temporal aspects of regulation is to perform time course studies.

Third, proteins that do not change in response to the mRNA change, or change in a different manner than the mRNA change, may be regulated at post-transcriptional levels. There are general considerations on the relation between gene expression (mRNA) and gene production (protein) with respect to post-transcriptional events. The binding states of mRNA with active from or inactive form of ribosomes, stability of mRNA, alternative splicing, protein turnover, specific proteolytic processing and posttranslational modification, all can have large impact on the nature and level of protein production [14]. By incorporating these processes, we can generate more regulatory links and networks [15].

Besides these general factors, the relation between mRNA and protein can depend on the type of protein. For extracellular-located secreted proteins, the transport control might be more important than upstream transcription and translation control. Also, the intracellular pool of the secreted proteins may buffer the effect of transcription and translation. If we would examine only intracellular or extracellular location for a gene 
encoding a secreted protein, we have a higher chance of getting non-correlated data between gene expression and the level of the protein, compared to a gene encoding an intracellular-located protein. However, when we combine the intra and extracellular compartments, we most likely will find the similar correlations for secreted proteins as for intra-cellular-located proteins. This may also be true for organelle or fractionation proteomics. A less tight relation can be expected between the mRNA and the protein in one organelle or one fraction of the cell. For instance, the level of GLUT4 in the membrane is highly controlled by insulin, and is only influenced to a small extent by its mRNA level. This type of discrepancy between the mRNA and the protein can be entirely explained by a inconsistency in our definition of a system. When we consider the transcriptome, the complete cell is taken as a system, when we look at the extracellular or organelle proteome, only that part of the system is taken. Furthermore, mitochondrion as an organelle defines an even more complex system, because it has its own chromosome and transcription and translation machinery. In the case of an observed discrepancy, an involvement of protein transport and processing should be taken into account.

A certain stimulus can determine a specific relation between mRNA and protein. We observed that the treatments with insulin (Chapter 3) and rosiglitazone (Chapter 4), which were conducted in parallel, lead to different relation patterns between the same set of mRNA and related proteins (Table 1). Insulin induced a general discrepancy between the mRNA level and the extracellular level of these proteins, while rosiglitazone treatment maintained the correlation. Insulin is a potent hormone, and has profound impacts in the cell, covering metabolism, cell survival, growth and other functions [16]. Insulin operates through signal transduction, resulting primarily in protein modifications and only in adaptive mRNA changes. It has been shown that protein transport is regulated by insulin [17-20]. As we showed in Chapter 3, the protein processing module is also regulated by insulin. Compared with insulin, rosiglitazone hits gene transcription first, through it transcription factor binding activity, and thus affects protein levels. In accord with this, we showed in Chapter 4 that rosiglitazone has defined effects on energy metabolism, and has less power in protein translation and processing. Therefore the correlation between $\mathrm{mRNA}$ and protein is not interfered by rosiglitazone.

In summary, it is a functional advantage for the cell to be able to modulate its functionality at different levels of integration. This makes the cell more flexible and skilled in its adaptation to the environment, but results in a 'discrepancy' between different 'omics' datasets. 
Table 1. The change of mRNA and extracellular protein of 3T3-L1 adipocytes under the 2-day treatment of insulin or rosiglitazone.

\begin{tabular}{|c|c|c|c|c|}
\hline & \multicolumn{2}{|c|}{ Insulin } & \multicolumn{2}{|c|}{ Rosiglitazone } \\
\hline & $\mathrm{mRNA}^{1}$ & $\begin{array}{c}\text { Extracellular } \\
\text { protein }^{2}\end{array}$ & $\mathrm{mRNA}^{1}$ & $\begin{array}{c}\text { Extracellular } \\
\text { protein }^{2}\end{array}$ \\
\hline Collagen type I alpha 1 & 1.35 & + & $0.71 *$ & - \\
\hline Complement $\mathrm{C} 3$ & 0.96 & $+-^{3}$ & $0.39 * *$ & - \\
\hline Adipsin & 0.89 & + & $0.28 * *$ & - \\
\hline SPARC & 1.08 & + & $0.62 * *$ & - \\
\hline Peroxiredoxin & 1.00 & - & $1.39 * *$ & \pm \\
\hline
\end{tabular}

The integration of "omics" data definitely needs computational tools. Although, in data integration the algorithms are powerful to align a positive match [4], they are weak to deal with negative mismatches. When a mismatch or discrepancy occurs, the manual input with existing biological knowledge is needed to process the data sets in a fruitful way, until the 'bioinformatic' tool is capable to make logical links with all our biological knowledge. Our research on the insulin effect on the secretion of 3T3-L1 adipocytes in Chapter 3 provides a good example on how to handle the discrepancy and to generate useful information on the signalling flow in the cells. We observed that insulin has a large effect on secretion but not on transcription of secreted protein genes. We found that this discrepancy may be partly explained by the transcriptional upregulation of processing protein genes. Our results have an important biological meaning, since they help to understand at what molecular level endocrine responses of adipocytes are triggered by insulin. It reveals that the module of post-translational modification is an important cellular target of insulin, not only for the signal transduction, but also for the regulation of secretion. Our results are also important with respect to the methodology of integrating data. This study is one of the first to use both transcriptomics and proteomics and clearly demonstrates the added value of a combined genomics approach to study biological mechanisms.

\section{Message}

Life seems simple, robustly continues its own way. However, life is complex, with numerous interacted networks of genes, transcripts, proteins, and metabolites. And life is dynamic, with many modules inside processing and digesting the information from the environment. Viewing the cell as running functional modules instead of a bunch of genes can help us to catch the holistic perspective of the cell without getting lost in the sea of 'omics 'data. 


\section{How useful is the 3T3-L1 cell line as an adipocyte model?}

The 3T3-L1 cell line is among the first established preadipocytes lines that have been characterized [21, 22]. The convenience of culturing in vitro has made 3T3-L1 cells a popular model system in adipogenesis studies. Increasing knowledge on the molecular mechanisms active in adipocytes has been generated with 3T3-L1 as a model. For scientists, the more extensive background knowledge is available, the more preferred the model is. Therefore, 3T3-L1 together with its close relative 3T3-F442A are currently the two most used cell lines in adipose differentiation studies [22, 23]. Also, 3T3-L1 adipocytes are extensively employed to study the insulin actions in adipocytes $[24,25]$ and in the specific field of adipocyte secretion, 3T3-L1 adipocytes are often used as a model to investigate the secretion pathways and regulation [17-20, 26]. Altogether, this motivated us to choose the 3T3-L1 cell line as an adipocyte model.

On the other hand, it is known that 3T3-L1 adipocytes, having multilocular fat droplets and lacking leptin production capacity, are not identical to fully mature white adipocytes in vivo, which are the major source of leptin and have only one big fat droplet per cell [21, 27]. Furthermore, minor differences in the transcriptional programme between 3T3-L1 adipocytes and in vivo adipocytes exist [28], which might be caused by a general difference between in vitro cell lines and in vivo cells: the former are aneuploid and the latter are diploid [29]. 3T3-L1 adipocytes have no regional identity compared to primary cultures from a specific depot, which might be important to characterize adipocyte metabolic activity and response to stimuli $[30,31]$. These differences in phenotype can be just due to a general drawback of in vitro cell culture, lacking a factor(s) or condition(s) that are present in the tissue context and necessary for a key transcriptional regulation. Two studies, the development of 3T3-L1 adipocytes following subcutaneous injection into nude mouse to mature fat pads that are histologically indistinguishable from white adipose tissue [32], and the restored expression of leptin gene in closely related 3T3-F442A adipocytes in vivo following transplantation [33], indicate that the genetic background of adipocyte is still conserved in these cell lines and that these cells can faithfully mimic the in vivo situation once the proper communication and control signals are present.

Since the 3T3-L1 cell line is derived from a mouse embryo, the species difference needs to be taken into account when extrapolating new concepts to adipocytes in humans. Overall, among experimental model species, rodents have the most similar lipid metabolism as humans, with respect to tissue sites of de novo fatty acid synthesis or lipogenesis and primary carbon precursor sources [34]. But for specific process discrepancies exist. The adipose tissue of rodents responds to more types of hormones than humans adipose tissue, thus the metabolic regulation can be different [34]. For example, rosiglitazone can induce the expression of glycerol kinase in 3T3-L1 adipocytes [35], but this effect could not be confirmed in vivo in humans nor in primary human cell culture [36]. Our own results (Chapter 4) confirmed the increased expression of the glycerol kinase gene in 3T3-L1 adipocytes by rosiglitazone treatment. However, in contrast to the suggestion of Guan et al. that this leads to a recycling of the lipolysis product glycerol to increase lipid synthesis [35], we observed an increased release of glycerol to the medium and reduced lipid content, which implies a 'futile' 
cycle of triglyceride breakdown and re-synthesis from glycerol and free fatty acids. Interestingly, human adipocytes in vivo and 3T3-L1 adipocytes in our experiment shared the common metabolic phenotype with respect to the increased release of glycerol, despite the divergent regulation of glycerol kinase expression.

For secreted adipokines, species differences are an important issue to consider for at least three reasons. First is the difference in expression specificity. Resistin is maybe the best example. The source of circulating resistin in mice and humans is drastically different. Mouse resistin is expressed predominantly in white adipocytes [37], whereas a scan of a variety of human tissues showed that human resistin is expressed at the highest level in macrophages in bone marrow followed by lung, with almost undetectable levels in adipocytes [38]. In Chapter 5, we discussed the source of PBEF/NMRPT/visfatin. The secretion from 3T3-L1 adipocytes [39] and high abundance in brown and white adipose tissue of mice as detected in a large-scale analysis of the mouse tissue transcriptome [40] conflicts with its human expression profile. In humans, the adipocytes express this gene much lower than total blood cells [40]. Second is the difference in regulatory and response patterns. For example, adipsin is abundantly expressed in 3T3-L1 adipocytes, as well as in primary adipocytes of both rodents and humans. The species difference exists in its production and circulation level at obese status, which is decreased in rodents [41], but increased in humans [42]. Third is the function of specific adipokines. Let us look at the most famous adipokine, leptin. The involvement of leptin in the development of obesity in $o b / o b$ [43] and $d b / d b$ [44] mouse models establishes its role in sensing the nutrition status, and regulating food intake and energy expenditure via hypothalamic receptors and the sympathetic nervous system. While this is true in rodents, in humans leptin senses the nutrition status not for controlling energy uptake and metabolism, but for permission of the onset of puberty and reproduction via the hypothalamo-pituitary-gonadal axis [45]. Again, the genetic background of adipocytes is not the only determinant in understanding the physiological role of adipokines, which needs to be examined and understood in the context of whole body physiology, developmental programs and evolutionary survival strategies. For the rodent models living in a laboratory, feeding is a continuous process, while the humans have distinguished feeding and fasting periods. This difference of food intake pattern might determine our human adipose tissue operates, responds and communicates (by secreted molecules) in a different way. As Arner said, men are not mice [46].

Despite the above considerations, the use of the 3T3-L1 cell line as an adipocyte model will continue. Although we do not know what are the best criteria to judge how close and how far 3T3-L1 adipocytes are from a perfect adipocytes model, some characteristics, at least the key ones, such as fat accumulation, insulin signalling and PPAR $\gamma$ signalling pathways are reflected well in 3T3-L1 cells. The advantage of using a cloned cell line is also of importance with regard to cell-population homogeneity. In Chapter 4, the advantage to use such a cell line but not an in vivo tissue to elicit the possible mechanisms of rosiglitazone is clearly demonstrated. Caution should be taken to extrapolate the findings in 3T3-L1 adipocytes without verification in human adipocytes. Ideally this should be done in the in vivo context. This principle was applied in this thesis. We detected pigment epithelial-derived factor (PEDF) in the culture media of both 3T3-L1 preadipocytes and adipocytes, whereupon it was suggested as a 
possible novel adipokine (Chapter 2). The large-scale analysis of the human tissue transcriptome showed that PEDF is almost exclusively expressed in human adipocytes [40], which encouraged us to move on to humans. In Chapter 6 , analysis in humans showed that the circulation level of PEDF does positively correlate with fat, especially with visceral fat. This warrants the further studies on its role in obesity and visceral fat related disorders. To highlight the importance of human validation, in Chapter 5 we assessed visfatin in a similar way, but failed to show any correlation between its circulating level and adipose mass, leaving us to question its role in human as an adipocyte-specific adipokine.

From the studies presented in Chapters 2, 3 and 4, we noticed that extracellular matrix proteins, particularly collagens, contribute to a significant part of 3T3-L1 cells secreted proteins, and these collagens are actively regulated not only during the adipocyte differentiation process, but also by stimuli such as insulin and rosiglitazone in the mature stage. A protein turnover study confirmed that 3T3-L1 adipocytes do actively synthesize collagens and collagens are the proteins with the highest turnover in the cell [47]. However, another proteomics study on rat primary adipocytes could not find most of these collagens or collagens related processing enzymes in the culture medium [48]. This poses the question whether the relationship between collagens and adipocytes is only an artefact of in vitro culture or not. The adherence to culture dishes might require the adipocytes to develop more proteins for the extracellular matrix to establish contact with the culture surface, while the primary adipocytes are floating in the culture medium. Across species, adipocytes do have an abundant extracellular matrix in vivo. Every adipocyte is supported by a basement membrane, composed by collagens and other extracellular matrix proteins as examined by immunohistochemistry [49]. A systematic survey of active genes in human adipose tissue using microarrays also showed that extracellular matrix proteins such as collagen type I, III, IV and VI are predominant and expressed at high level [50]. The synthesis of collagen may have a direct functional link to fat metabolism. The collagen synthesis rate of another line of uncloned 3T3 cells, 3T3-M2, which is not capable to accumulate fat, is near half of that in 3T3-L1 preadipocytes [21]. A system biology analysis showed that for fatty acids utilization in yeast, both metabolism genes and cell morphology genes are necessary [51]. This suggests that 'passive' structural proteins and active metabolic enzymes have a systemlevel connection. Together, it implies that the link between collagens and adipocytes is not merely an artefact of in vitro cell culture. In this context, the extracellular matrix components, particularly collagens, are potential targets for intervention on obesity and related disorders. This view is supported by P. Scherer, although he has focused on the role of extracellular matrix in angiogenesis within adipose tissue [52].

Beyond the possible functional role, the relation of collagens and adipocytes may tell us more about the origin of preadipocytes. Adipocytes have been described to develop from mesenchymal cell lineage. This adipocytic lineage together with osteocytic lineages and endothelial lineage are thought to be derived from the same bone marrow multipotent mesenchymal stem cells $[53,54]$. Osteoblasts and endothelial cells are also specialized in the synthesis of extracellular matrix, mainly collagens [55, 56]. It is not strange to see that adipocytes, which are from the same origin, also have this specificity. Interestingly, all three cell types, osteoblasts, endothelial cells and (pre)adiopocytes, 
readily show adaptive proliferation, in response to wound repair, bone damage and a positive energy balance, respectively. This adaptive capacity may underlie their extracellular matrix synthesis capacity.

\section{Message}

The 3T3-L1 cell line is a useful white adipocyte model to study adipocyte differentiation, extracellular matrix remodelling, and response to stimuli, including the secretion and intracellular transport of proteins. When it is used as a mirror for human white adipocytes, remember that men are not mice.

\section{What is the role of the secretory function in the physiology of adipose tissue?}

In 1987, Siiteri identified the endocrine role of adipose tissue in relation to sex steroids [11]. In 1996, Smith entitled adipose tissue as "endocrine organ" with regard to the role of leptin [57]. In 1998 Mohamed-Ali and colleagues made a first overview on the secreted active products from white adipose tissue, and clearly identified the endocrine substances (hormones) and also paracrine substances of adipose tissue up to that date [58]. In the literature, 'endocrine organ' is not a well-defined term and is often used to title a tissue/organ that does not belong to endocrine system, such as intestine, lung, and even skin. Since nearly every organ in the animal is capable of secreting some molecules into the bloodstream and with some remote targets, which is called endocrine action, as defined by the Medical Subject Headings (MeSH) of NIH, the term 'endocrine organ' seems not of much unique value and importance. However, applying this title to adipose tissue emphasizes its active role in contrast to its original "lazy" title of 'connective tissue'. It is also understandable to use 'endocrine organ', rather than 'endocrine tissue' for adipose tissue, since it shows aspects of high level organisation. At the time, Mohamed-Ali and colleagues gave the paracrine function the same importance and called adipose tissue 'endocrine and paracrine organ'. Leaving out the much abused use of the term 'endocrine organ' in literature, the title of endocrine and paracrine organ for adipose tissue is good and partially accurate (I will provide the argument for the partiality below). But this title has a tendency to be split and only "endocrine organ" is in fashion now (Figure 1).

The endocrine function of adipose tissue is well illustrated by its secretion of hormones, leptin and adiponectin. Although the function of leptin later has been found to be diverse between rodents and humans [59], and leptin is also produced in placenta and fetal tissues [45], this does not do harm to its position as a hormone. It is produced in adipose tissue and exerts its effect either in satiety or reproduction by targeting its receptors in the brain hypothalamus, exactly complying with the definition of a hormone. Adiponectin as one of the most actively expressed genes in adipocytes and secreted into circulation in significant amounts, can address its receptor in liver and skeletal muscle to regulate energy metabolism [60]. Interestingly, in contrast to other hormones, an endogenous transient regulation of leptin and adiponectin has not been observed, indicating a chronic regulation and they possibly serve as a long-term indicator of body energy intake and requirement. Although sex steroid hormones can be 
secreted from adipocytes, their significant contribution to the system level is in doubt and maybe occurs only under special circumstances [61]. Cytokines are generally considered to act locally in a paracrine or autocrine rather than endocrine manner, according to MeSH. They differ from classical hormones also with regard to the fact that they are produced by a number of tissues or cell types, rather than by specialized glands.

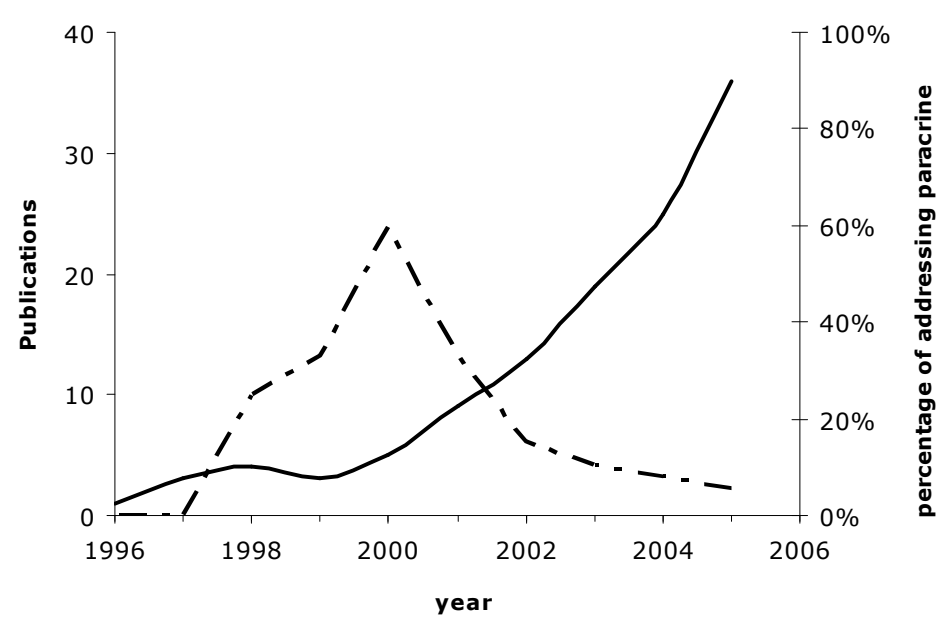

Fig. 1. The publications concerning adipose tissue as an endocrine organ in the last 10 years. The data were analyzed by ISI web of knowledge. The increasing number of the publications ( - ) and decreased coverage percentage of the paracrine function $(\bullet-)$ are shown.

In addition to the above endocrine and putative endocrine factors, other secreted proteins act locally. We already know that lipoprotein lipase helps adipocytes to take up lipids [62]; extracellular matrix components support the morphology of adipocytes as a fragile fat bag [49]; angiotensinogen is involved in recruiting new adipocytes via adipogenesis [63]; macrophage migration inhibitory factor is involved in recruitment of macrophages to adipose tissue to remove dead cells [64, 65]; pigment-epithelium derived factor [66] and nerve growth factor [67] can be involved in modulation of innervation; and extracellular matrix components might be involved in angiogenesis within adipose tissue [55]. These autocrine and paracrine factors play important roles in the physiology and development of adipose tissue, and in this way affect the etiology and complications of obesity and related diseases. Not only the adipogenesis process and adipocytes can be targets for intervention against obesity and related complications, but also the adipocyte paracrine action may be targeted for this purpose. For example, adipose tissue appears as the most sensitive of the non-malignant tissues to angiogenesis inhibitors, as illustrated by weight loss in a genetic obese mouse model, without adverse 
effects, as a result of systemic anti-angiogenesis drug treatment [68]. In diet-induced obese mice, a killing peptide targeted to existing blood vessels in adipose tissue induced apoptosis of vasculature and resulted in ablation of white adipose tissue [69].

Every cell lives in a communicating context with other cells in close and/or remote distance. Therefore the endocrine/paracrine/autocrine function does not make adipocytes and adipose tissue special. The real special nature of adipocyte and adipose tissue is their ability to maintain lipid homeostasis by fat accumulation and lipolysis. The endocrine and paracrine function is to serve the main role of adipose tissue as a specialized energy reservoir with automated indicators and a close link to the whole organism via the vasculature and nervous systems. In this sense, "endocrine and paracrine organ' leaves the major and specific nature of adipose tissue out, so this title is only partially correct.

For adipose tissue, efficient uptake of the excess energy and mobilizing the reserved energy in response to the energy status of the body is the main role (Figure 2). Apparently, the secretory function of adipose tissue needs to be regulated synchronously with its energy metabolism status. In Chapter 4, we found that a general repression of genes encoding secreted proteins occurs when lipid catabolism is activated by rosiglitazone in mature 3T3-L1 adipocytes. We suspect that this involves a general mechanism, in which the energy status and secretion are connected. A recent publication addressing the role of redox potential in secretory pathways is in line with our hypothesis. Scherer and his group found that disulfide bonds of resistin and adiponectin are unusually exposed towards outside and of critical importance for secretion and can be regulated by redox potential within secretory pathways [52]. The redox potential is governed by the level of glutathione and ultimately by reactive oxygen species (ROS). ROS are by-products of mitochondrial respiration, which might be elevated with high energy metabolism in adipocytes. Scherer further assumed that all secreted proteins whose secretion depending on disulfide bonds can be affected by the same mechanism [52]. We observed that glutathione metabolism was significantly changed by rosiglitazone treatment (Chapter 4 ). The gene expression profile indicates that a major part of the glutathione S-transferase genes are down-regulated while the use of glutathione to detoxify lipid peroxides may be increased by rosiglitazone. This can cause a decrease of the cellular glutathione level and subsequently affect the secretory pathways, possibly towards a down-regulation in general. To release this burden on secretory pathways, the gene expression of secreted proteins might be repressed as a negative feedback. In this view, energy metabolism is indeed central for adipocytes, and the secretion function is under the control of the energy status.

The anti-adipogenic effect in mature adipocytes and the restoration of adipokine secretion by rosiglitazone that are elucidated in Chapter 4 are attractive. It not only (partially) explains the anti-diabetic mechanism, but also suggests a healthy beneficial effect of this drug. Rosiglitazone can enhance the energy metabolism while also increase the energy metabolism capacity by mitochondria biogenesis. It is not known in which direction ROS level can be changed in adipocytes treated with rosiglitazone. However, an increase of ROS level has been suggested [70]. The excess ROS may cause cell death directly, and/or indirectly by over-modifying the secretory function of 
adipocytes to such an extent that is not sufficient to maintain adipocyte physiology. The cell death in adipose tissue can be the initiation of inflammation. Will the decreased inflammation by TZDs treatment in short-term finally turn to be increased inflammation? We need long-term studies in vivo to well characterize this potent drug family. Similar consideration also applies to drugs that increase lipolysis and/or fatty acid oxidation in adipocytes. The increased free fatty acids generated from lipolysis either are burned in adipocytes or enter the circulation. This may cause increased oxidative stress in adipocytes and the stress to other organs by increased free fatty acids in circulation. In short-term, the loss of fat mass by these drugs can be beneficial, while in long-term, the adverse effects might counteract the beneficial effects. Again, long-term studies in vivo are in need.

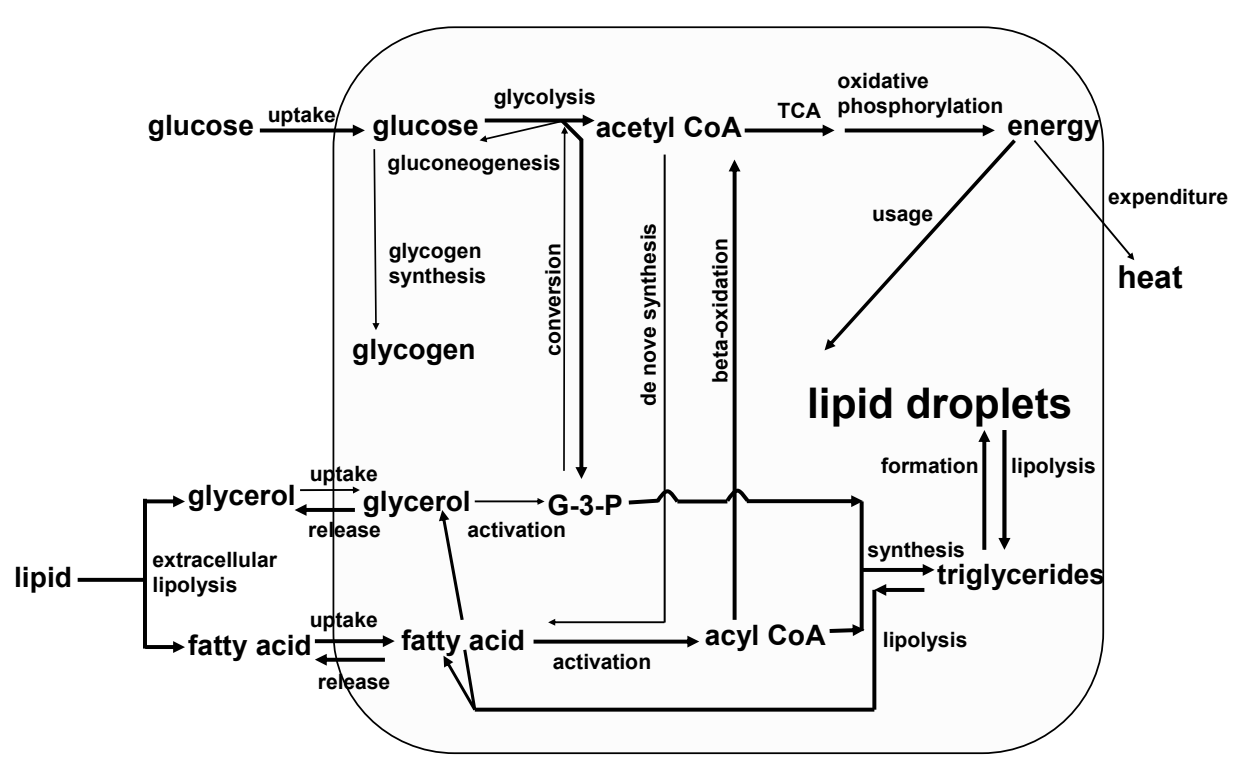

Fig. 2. Energy substances metabolism network of adipocytes. Environmental glucose and fatty acids are taken up into the cells and anabolized for lipid synthesis. They are also catabolized to generate energy for anabolism processes, such as de novo fatty acids synthesis, substance activation, lipid synthesis, and other fundamental functions of the cell. Meanwhile, part of the energy is lost from the cell and expanded as heat to the environment. Upon lipolysis, lipids in the droplet are catabolized to glycerol and free fatty acid, and released into the environment. These processes can all be affected by rosiglitazone (Chapter 4). The main directions of the energy substance flow in adipocytes under normal circumstance are in bold. 
The endocrine factors, including free fatty acids, require us to look at the physiology of adipocytes or adipose tissue in a broader system, at organism level, with organ-organ interactions. It is known that not only adipose tissue, but also liver, skeletal muscle, pancreases and brain are involved in maintaining glucose and lipid homeostasis. The interactions of adipose tissue with these organs play a role in the normal physiology of adipose tissue, while the immune system may interact with adipose tissue under pathogenic conditions. To unravel the etiology of metabolic syndrome and type 2 diabetes, the interaction between adipose tissue and these organs have been intensively studied, leading to a hormone and metabolite flux view [60, 71, 72]. In this thesis, we studied the circulating level of (putative) adipocyte secreted proteins in humans, and found the circulation levels of these proteins all can be influenced by other organs than adipose tissue in the body to some extent. As for PBEF/NAMPT/visfatin a close link with lipid profile, especially HDL-cholesterol, in the plasma as shown in Chapter 5, tempted us to speculate that the liver, which is a determining organ in HDL-cholesterol metabolism, might be the major source of this protein in circulation. Although $\mathrm{PBEF} / \mathrm{NAMPT} /$ visfatin is also a cytokine-like protein $[73,74]$, our data (unpublished) showed a complete absence of a correlation between circulating PBEF/NAMPT/visfatin and the inflammation marker CRP in either the inflamed subjects with heterogeneous background, or in the relatives and spouses of familial combined hyperlipidemia families. This suggests that the immune system is not involved in the production of the putative adipokine. As shown in Chapter 6, PEDF has a strong correlation with adiposity in humans from normal weight till type I obesity (BMI 30-34.9) with normal glucose tolerance, but in obese people with impaired glucose tolerance, its circulation level lost such linear correlation with adiposity. This shows that under some circumstances, the signals from the body overwhelm the intrinsic capacity of adipocyte secretion. In addition, our unpublished data on acylation-stimulating protein (ASP) also strongly suggest an involvement of the liver in the formation of this 'adipokine' in the circulation. In fact, ASP is produced by inter-hydrolysis processing of complement C3, factor B and adipsin [75]. Adipsin and complement C3 are abundantly secreted proteins from adipocytes in both mouse and humans, but complement factor B is not. In humans, liver is the predominant organ to produce factor B, but can not produce adipsin [40]. Therefore cooperation between the liver and adipose tissue should occur to produce ASP in humans.

\section{Message}

Adipose tissue is an energy storage organ supported by the secretory function of adipocytes. Nowadays, its endocrine function is exaggerated, while the paracrine and autocrine functions are underestimated. The integration of gene expression, protein production, translocation and secretion, and the flux of metabolites at organ and whole organism levels is a promising way forward to understand the functional role of adipocytes and adipose tissue. 


\section{References}

1. Seldin, M.F., Toward functional genomics. Methods, 1997. 13(4): p. 325-6.

2. Galperin, M.Y. and M.J. Ellison, Systems biology: sprint or marathon? Curr Opin Biotechnol, 2006. 17(5): p. 437-9.

3. Stelling, J., et al., Robustness of cellular functions. Cell, 2004. 118(6): p. 675-85.

4. Ge, H., A.J. Walhout, and M. Vidal, Integrating 'omic' information: a bridge between genomics and systems biology. Trends Genet, 2003. 19(10): p. 551-60.

5. Liu, E.T., Systems Biology, Integrative Biology, Predictive Biology. Cell, 2005. 121(4): p. 505-506.

6. Van Dien, S. and C.H. Schilling, Bringing metabolomics data into the forefront of systems biology. Mol Syst Biol, 2006. 2: p. 20060035.

7. Bork, P., Is there biological research beyond Systems Biology? A comparative analysis of terms. Mol Syst Biol, 2005. 1: p. 20050012.

8. Kitano, H., Systems biology: a brief overview. Science, 2002. 295(5560): p. 1662-4.

9. Nurse, P., Systems biology: understanding cells. Nature, 2003. 424(6951): p. 883.

10. Wiener, N., Cybernetics or Control and Communication in the Animal and the Machine. 1948, Cambridge, MA: MIT Press.

11. Siiteri, P.K., Adipose tissue as a source of hormones. Am J Clin Nutr, 1987. 45(1 Suppl): p. 277-82.

12. van Anken, E., et al., Sequential waves of functionally related proteins are expressed when B cells prepare for antibody secretion. Immunity, 2003. 18(2): p. 243-53.

13. Coulouarn, C., et al., Genome-wide response of the human Hep3B hepatoma cell to proinflammatory cytokines, from transcription to translation. Hepatology, 2005. 42(4): p. 946-55.

14. Hegde, P.S., I.R. White, and C. Debouck, Interplay of transcriptomics and proteomics. Curr Opin Biotechnol, 2003. 14(6): p. 647-51.

15. Ideker, T., et al., Integrated genomic and proteomic analyses of a systematically perturbed metabolic network. Science, 2001. 292(5518): p. 929-34.

16. Kahn, C.R. and M.F. White, The insulin receptor and the molecular mechanism of insulin action. J Clin Invest, 1988. 82(4): p. 1151-6.

17. Zhong, Q., et al., Endothelin-1 inhibits resistin secretion in 3T3-L1 adipocytes. Biochem Biophys Res Commun, 2002. 296(2): p. 383-7.

18. Seki, T., et al., Reciprocal regulation of tissue-type and urokinase-type plasminogen activators in the differentiation of murine preadipocyte line 3T3-L1 and the hormonal regulation of fibrinolytic factors in the mature adipocytes. J Cell Physiol, 2001. 189(1): p. 72-8.

19. Millar, C.A., et al., Adipsin and the glucose transporter GLUT4 traffic to the cell surface via independent pathways in adipocytes. Traffic, 2000. 1(2): p. 141-51.

20. Bogan, J.S. and H.F. Lodish, Two compartments for insulin-stimulated exocytosis in 3T3-L1 adipocytes defined by endogenous ACRP30 and GLUT4. J Cell Biol, 1999. 146(3): p. 609-20.

21. Green, H. and M. Meuth, An established pre-adipose cell line and its differentiation in culture. Cell, 1974. 3(2): p. 127-33.

22. Ntambi, J.M. and K. Young-Cheul, Adipocyte differentiation and gene expression. J Nutr, 2000. 130(12): p. $3122 \mathrm{~S}-3126 \mathrm{~S}$.

23. Gregoire, F.M., C.M. Smas, and H.S. Sul, Understanding adipocyte differentiation. Physiol Rev, 1998. 78(3): p. 783-809.

24. Watson, R.T., M. Kanzaki, and J.E. Pessin, Regulated membrane trafficking of the insulin-responsive glucose transporter 4 in adipocytes. Endocr Rev, 2004. 25(2): p. 177-204.

25. Summers, S.A., et al., Differentiation-dependent suppression of platelet-derived growth factor signaling in cultured adipocytes. J Biol Chem, 1999. 274(34): p. 23858-67.

26. Fasshauer, M., et al., Hormonal regulation of adiponectin gene expression in 3T3-L1 adipocytes. Biochem Biophys Res Commun, 2002. 290(3): p. 1084-9.

27. MacDougald, O.A., et al., Regulated expression of the obese gene product (leptin) in white adipose tissue and 3T3-L1 adipocytes. Proc Natl Acad Sci U S A, 1995. 92(20): p. 9034-7.

28. Soukas, A., et al., Distinct transcriptional profiles of adipogenesis in vivo and in vitro. J Biol Chem, 2001. 276(36): p. 34167-74.

29. Bell, A., L. Grunder, and A. Sorisky, Rapamycin inhibits human adipocyte differentiation in primary culture. Obes Res, 2000. 8(3): p. 249-54.

30. Wajchenberg, B.L., Subcutaneous and visceral adipose tissue: their relation to the metabolic syndrome. Endocr Rev, 2000. 21(6): p. 697-738.

31. Giorgino, F., L. Laviola, and J.W. Eriksson, Regional differences of insulin action in adipose tissue: insights from in vivo and in vitro studies. Acta Physiol Scand, 2005. 183(1): p. 13-30.

32. Green, H. and O. Kehinde, Formation of normally differentiated subcutaneous fat pads by an established preadipose cell line. J Cell Physiol, 1979. 101(1): p. 169-71. 
33. Mandrup, S., et al., Obese gene expression at in vivo levels by fat pads derived from s.c. implanted 3T3F442A preadipocytes. Proc Natl Acad Sci U S A, 1997. 94(9): p. 4300-5.

34. Bergen, W.G. and H.J. Mersmann, Comparative aspects of lipid metabolism: impact on contemporary research and use of animal models. J Nutr, 2005. 135(11): p. 2499-502.

35. Guan, H.P., et al., A futile metabolic cycle activated in adipocytes by antidiabetic agents. Nat Med, 2002. 8(10): p. 1122-8.

36. Tan, G.D., et al., A "futile cycle" induced by thiazolidinediones in human adipose tissue? Nat Med, 2003. 9(7): p. 811-2; author reply 812 .

37. Steppan, C.M., et al., The hormone resistin links obesity to diabetes. Nature, 2001. 409(6818): p. $307-12$.

38. Patel, L., et al., Resistin is expressed in human macrophages and directly regulated by PPAR gamma activators. Biochem Biophys Res Commun, 2003. 300(2): p. 472-6.

39. Fukuhara, A., et al., Visfatin: a protein secreted by visceral fat that mimics the effects of insulin. Science, 2005. 307(5708): p. 426-30.

40. Su, A.I., et al., A gene atlas of the mouse and human protein-encoding transcriptomes. Proc Natl Acad Sci U S A, 2004. 101(16): p. 6062-7.

41. Rosen, B.S., et al., Adipsin and complement factor D activity: an immune-related defect in obesity. Science, 1989. 244(4911): p. 1483-7.

42. Napolitano, A., et al., Concentrations of adipsin in blood and rates of adipsin secretion by adipose tissue in humans with normal, elevated and diminished adipose tissue mass. Int J Obes Relat Metab Disord, 1994. 18(4): p. 213-8.

43. Zhang, Y., et al., Positional cloning of the mouse obese gene and its human homologue. Nature, 1994. 372(6505): p. 425-32.

44. Chen, H., et al., Evidence that the diabetes gene encodes the leptin receptor: identification of a mutation in the leptin receptor gene in $\mathrm{db} / \mathrm{db}$ mice. Cell, 1996. 84(3): p. 491-5.

45. Cervero, A., et al., The role of the leptin in reproduction. Curr Opin Obstet Gynecol, 2006. 18(3): p. 297303.

46. Arner, P., Resistin: yet another adipokine tells us that men are not mice. Diabetologia, 2005. 48(11): p. 2203-5.

47. Bouwman, F., J. Renes, and E. Mariman, A combination of protein profiling and isotopomer analysis using matrix-assisted laser desorption/ionization-time of flight mass spectrometry reveals an active metabolism of the extracellular matrix of 3T3-L1 adipocytes. Proteomics, 2004. 4(12): p. 3855-63.

48. Chen, X., et al., Quantitative proteomic analysis of the secretory proteins from rat adipose cells using a 2D liquid chromatography-MS/MS approach. J Proteome Res, 2005. 4(2): p. 570-7.

49. Pierleoni, C., et al., Fibronectins and basal lamina molecules expression in human subcutaneous white adipose tissue. Eur J Histochem, 1998. 42(3): p. 183-8.

50. Maeda, K., et al., Analysis of an expression profile of genes in the human adipose tissue. Gene, 1997. 190(2): p. 227-35.

51. Smith, J.J., et al., Expression and functional profiling reveal distinct gene classes involved in fatty acid metabolism. Mol Syst Biol, 2006. 2: p. 20060009.

52. Scherer, P.E., Adipose tissue: from lipid storage compartment to endocrine organ. Diabetes, 2006. 55(6): p. $1537-45$.

53. Pittenger, M.F., et al., Multilineage potential of adult human mesenchymal stem cells. Science, 1999. 284(5411): p. 143-7.

54. Kim, D.H., et al., Gene expression profile of cytokine and growth factor during differentiation of bone marrow-derived mesenchymal stem cell. Cytokine, 2005. 31(2): p. 119-26.

55. Kalluri, R., Basement membranes: structure, assembly and role in tumour angiogenesis. Nat Rev Cancer, 2003. 3(6): p. 422-33.

56. Karsenty, G. and R.W. Park, Regulation of type I collagen genes expression. Int Rev Immunol, 1995. 12(2-4): p. 177-85.

57. Smith, S.R., The endocrinology of obesity. Endocrinol Metab Clin North Am, 1996. 25(4): p. 921-42.

58. Mohamed-Ali, V., J.H. Pinkney, and S.W. Coppack, Adipose tissue as an endocrine and paracrine organ. Int J Obes Relat Metab Disord, 1998. 22(12): p. 1145-58.

59. Himms-Hagen, J., Physiological roles of the leptin endocrine system: differences between mice and humans. Crit Rev Clin Lab Sci, 1999. 36(6): p. 575-655.

60. Kadowaki, T., et al., Adiponectin and adiponectin receptors in insulin resistance, diabetes, and the metabolic syndrome. J Clin Invest, 2006. 116(7): p. 1784-92.

61. Mayes, J.S. and G.H. Watson, Direct effects of sex steroid hormones on adipose tissues and obesity. Obes Rev, 2004. 5(4): p. 197-216.

62. Semenkovich, C.F., et al., Insulin regulation of lipoprotein lipase activity in 3T3-L1 adipocytes is mediated at posttranscriptional and posttranslational levels. J Biol Chem, 1989. 264(15): p. 9030-8. 
63. Ailhaud, G., M. Teboul, and F. Massiera, Angiotensinogen, adipocyte differentiation and fat mass enlargement. Curr Opin Clin Nutr Metab Care, 2002. 5(4): p. 385-9.

64. Skurk, T., et al., Production and release of macrophage migration inhibitory factor from human adipocytes. Endocrinology, 2005. 146(3): p. 1006-11.

65. Cinti, S., et al., Adipocyte death defines macrophage localization and function in adipose tissue of obese mice and humans. J Lipid Res, 2005. 46(11): p. 2347-55.

66. Tombran-Tink, J., The neuroprotective and angiogenesis inhibitory serpin, PEDF: new insights into phylogeny, function, and signaling. Front Biosci, 2005. 10: p. 2131-49.

67. Peeraully, M.R., J.R. Jenkins, and P. Trayhurn, NGF gene expression and secretion in white adipose tissue: regulation in 3T3-L1 adipocytes by hormones and inflammatory cytokines. Am J Physiol Endocrinol Metab, 2004. 287(2): p. E331-9.

68. Rupnick, M.A., et al., Adipose tissue mass can be regulated through the vasculature. Proc Natl Acad Sci U S A, 2002. 99(16): p. 10730-5.

69. Kolonin, M.G., et al., Reversal of obesity by targeted ablation of adipose tissue. Nat Med, 2004. 10(6): p. 625-32.

70. Feinstein, D.L., et al., Receptor-independent actions of PPAR thiazolidinedione agonists: is mitochondrial function the key? Biochem Pharmacol, 2005. 70(2): p. 177-88.

71. Frayn, K.N., Adipose tissue and the insulin resistance syndrome. Proc Nutr Soc, 2001. 60(3): p. 375-80.

72. Shoelson, S.E., J. Lee, and A.B. Goldfine, Inflammation and insulin resistance. J Clin Invest, 2006. 116(7): p. 1793-801.

73. Jia, S.H., et al., Pre-B cell colony-enhancing factor inhibits neutrophil apoptosis in experimental inflammation and clinical sepsis. J Clin Invest, 2004. 113(9): p. 1318-27.

74. Samal, B., et al., Cloning and characterization of the cDNA encoding a novel human pre-B-cell colonyenhancing factor. Mol Cell Biol, 1994. 14(2): p. 1431-7.

75. Cianflone, K., Z. Xia, and L.Y. Chen, Critical review of acylation-stimulating protein physiology in humans and rodents. Biochim Biophys Acta, 2003. 1609(2): p. 127-43. 
Supplementary materials 
Chapter 3

Supplementary Table 1. Quantitative real time PCR primer sequences

\begin{tabular}{|c|c|c|c|c|c|}
\hline gene & Refseq & sense primer $\left(5^{\prime}>3^{\prime}\right)$ & antisense primer $\left(5^{\prime}>3^{\prime}\right)$ & $\begin{array}{l}\text { product } \\
\text { length }\end{array}$ & $\mathrm{T}_{\text {annealing }}$ \\
\hline Rps 15 & NM_009091 & cggagatggtgggtagcatgg & acgggtttgtaggtgatggagaac & 118 & $60^{\circ} \mathrm{C}$ \\
\hline Sulf2 & NM_028072 & tgtaaaggctacaagcagtgcaac & cccaaccttcccatagctgtcc & 160 & $60^{\circ} \mathrm{C}$ \\
\hline Cspg2 & XM_488510 & tttcctgattggcattagtgaagagtc & gcacacataggaagtctcggtagg & 130 & $60^{\circ} \mathrm{C}$ \\
\hline Chst2 & NM_018763 & agcagatcaaacaggtggaggag & tcttgggaaccettctcaaagcc & 140 & $60^{\circ} \mathrm{C}$ \\
\hline P4hal & NM_011030 & ctgttctatatgagcgatgtgtctgc & tgecgtgtactgtaatctccttcc & 140 & $60^{\circ} \mathrm{C}$ \\
\hline Pcolce & NM_008788 & acaaaaccggagactggacctg & tggactgtagagaaccacgaagc & 178 & $60^{\circ} \mathrm{C}$ \\
\hline Collal & NM_007742 & cagattgagaacatccgcagcc & tgacctgtctccatgttgcagtag & 170 & $60^{\circ} \mathrm{C}$ \\
\hline Colla2 & NM_007743 & gccaacaagcatgtctggttagg & cgagctgagttgccatttcettg & 100 & $60^{\circ} \mathrm{C}$ \\
\hline Col3al & NM_009930 & agaagtctctgaagctgatgggatc & tagtctcattgccttgcgtgtttg & 158 & $60^{\circ} \mathrm{C}$ \\
\hline Col6a2 & NM_146007 & cgcaacatgacgctgttctctg & agggaagttctggacacacgatc & 103 & $60^{\circ} \mathrm{C}$ \\
\hline Col6a3 & XM_484897 & agcacaccgagcatccagttc & tccacaacctccataccagaatctc & 181 & $60^{\circ} \mathrm{C}$ \\
\hline Stcl & NM_009285 & tccttgccattcggaggtgttc & gaaggcttcggacaagtctgttg & 180 & $60^{\circ} \mathrm{C}$ \\
\hline$A d m$ & NM_009627 & ctaagtcgtgggaagagggaactac & gaatgtgggettcgctctgattg & 157 & $60^{\circ} \mathrm{C}$ \\
\hline$V e g f a$ & NM_009505 & accaaagccagcacataggagag & cggatcttggacaaacaaatgctttc & 140 & $60^{\circ} \mathrm{C}$ \\
\hline$V e g f b$ & NM_011697 & accaagtccgaatgcagatcctc & tatggcaaccetgtctggettc & 137 & $60^{\circ} \mathrm{C}$ \\
\hline $\operatorname{Veg} f \mathrm{c}$ & NM_009506 & cctgggaaatgtgcctgtgaatg & cggcatacttcttcactaaaggacag & 158 & $60^{\circ} \mathrm{C}$ \\
\hline Figf & NM_010216 & ccgccatccttactcaattatcagaag & caggcagtggagtctcgtcttg & 146 & $60^{\circ} \mathrm{C}$ \\
\hline Pik3r2 & NM_008841 & tcgtgtggctcacccagaaag & gcgtcctcatcctccatcagtg & 106 & $60^{\circ} \mathrm{C}$ \\
\hline $\operatorname{Irs} 2$ & XM_357863 & gccctctgccagcacctatg & cgcttcactctttcacgactgtg & 80 & $60^{\circ} \mathrm{C}$ \\
\hline
\end{tabular}


Chapter 3

Supplementary Table 2. Genes involved in insulin pathways

\begin{tabular}{|c|c|c|c|c|c|}
\hline \multirow[b]{2}{*}{$\begin{array}{l}\text { Gene } \\
\text { symbol }\end{array}$} & \multirow[b]{2}{*}{ Name } & \multicolumn{2}{|c|}{ Ins/Basal } & \multicolumn{2}{|c|}{ Ins + Glc/Glc } \\
\hline & & $\begin{array}{c}\text { fold } \\
\text { change }\end{array}$ & $p$ & $\begin{array}{c}\text { fold } \\
\text { change }\end{array}$ & $p$ \\
\hline Irs2 & Insulin receptor substrate 2 & 1.04 & 0.896 & -1.16 & 0.306 \\
\hline Irs1 & Insulin receptor substrate 1 & -1.07 & 0.658 & -1.10 & 0.497 \\
\hline Pik3r2 & $\begin{array}{l}\text { Phosphatidylinositol 3-kinase, regulatory subunit, } \\
\text { polypeptide } 2 \text { (p85 beta) }\end{array}$ & 1.22 & 0.046 & 1.39 & 0.011 \\
\hline Akt1 & Thymoma viral proto-oncogene 1 & 1.11 & 0.354 & 1.28 & 0.158 \\
\hline Akt2 & Thymoma viral proto-oncogene 2 & 1.09 & 0.448 & 1.12 & 0.254 \\
\hline Akt2 & Thymoma viral proto-oncogene 2 & 1.02 & 0.965 & 1.08 & 0.767 \\
\hline Frap1 & $\begin{array}{l}\text { FK506 binding protein 12-rapamycin associated protein } \\
1\end{array}$ & -1.15 & 0.247 & 1.00 & 0.919 \\
\hline Eif4e & Eukaryotic translation initiation factor $4 \mathrm{E}$ & 1.18 & 0.100 & 1.07 & 0.444 \\
\hline Rps6kb1 & Ribosomal protein S6 kinase, polypeptide (1p70/85s6k) & -1.10 & 0.135 & -1.10 & 0.435 \\
\hline Gsk3b & Glycogen synthase kinase 3 beta & 1.09 & 0.529 & 1.10 & 0.254 \\
\hline Gys3 & Glycogen synthase 3 , brain & -1.00 & 0.962 & 1.16 & 0.097 \\
\hline Ppp1r14b & $\begin{array}{l}\text { Protein phosphatase 1, regulatory (inhibitor) subunit } \\
\text { 14B }\end{array}$ & 1.02 & 0.801 & 1.10 & 0.457 \\
\hline Ppp1cb & Protein phosphatase 1 , catalytic subunit, beta isoform & 1.09 & 0.336 & 1.03 & 0.991 \\
\hline Ppp1cc & $\begin{array}{l}\text { Protein phosphatase 1, catalytic subunit, gamma } \\
\text { isoform }\end{array}$ & 1.11 & 0.185 & -1.00 & 0.874 \\
\hline Ppp1ca & Protein phosphatase 1 , catalytic subunit, alpha isoform & 1.08 & 0.050 & 1.18 & 0.027 \\
\hline Ppp1r11 & Protein phosphatase 1, regulatory (inhibitor) subunit 11 & 1.07 & 0.292 & 1.12 & 0.168 \\
\hline Ppp1r7 & Protein phosphatase 1, regulatory (inhibitor) subunit 7 & 1.12 & 0.079 & 1.03 & 0.536 \\
\hline Ppp1r3c & Protein phosphatase 1, regulatory (inhibitor) subunit $3 \mathrm{C}$ & -1.03 & 0.698 & 1.04 & 0.512 \\
\hline Foxo1 & Forkhead box O1 & 1.07 & 0.330 & -1.06 & 0.512 \\
\hline Bad & Bcl-associated death promoter & 1.12 & 0.297 & -1.13 & 0.117 \\
\hline Prkci & Protein kinase $\mathrm{C}$, iota & 1.06 & 0.512 & -1.08 & 0.561 \\
\hline Aps & Adaptor protein with pleckstrin homology and src & -1.15 & 0.252 & -1.11 & 0.301 \\
\hline Sorbs1 & Sorbin and SH3 domain containing 1 & 1.08 & 0.537 & -1.02 & 0.793 \\
\hline Flot2 & Flotillin 2 & 1.02 & 0.825 & 1.10 & 0.294 \\
\hline Flot1 & Flotillin 1 & -1.07 & 0.388 & 1.02 & 0.776 \\
\hline Stx $4 a$ & Syntaxin 4A (placental) & 1.04 & 0.713 & 1.02 & 0.724 \\
\hline Stxbp4 & Syntaxin binding protein 4 & -1.07 & 0.378 & -1.04 & 0.304 \\
\hline Slc2a4 & $\begin{array}{l}\text { Solute carrier family } 2 \text { (facilitated glucose transporter), } \\
\text { member } 4\end{array}$ & 1.03 & 0.517 & 1.07 & 0.163 \\
\hline Grb2 & Hypothetical D930050J11 & 1.06 & 0.440 & 1.11 & 0.101 \\
\hline Sos 1 & Son of sevenless homolog 1 (Drosophila) & 1.02 & 0.984 & -1.25 & 0.069 \\
\hline Kras2 & Kirsten rat sarcoma oncogene 2 , expressed & 1.06 & 0.443 & 1.14 & 0.251 \\
\hline Raf1 & V-raf-1 leukemia viral oncogene 1 & 1.08 & 0.231 & 1.04 & 0.687 \\
\hline Map2k1 & Mitogen activated protein kinase kinase 1 & 1.04 & 0.581 & -1.03 & 0.712 \\
\hline Mapk1 & Mitogen activated protein kinase 1 & 1.15 & 0.235 & 1.11 & 0.253 \\
\hline Mapk1 & Mitogen activated protein kinase 1 & 1.05 & 0.465 & -1.04 & 0.694 \\
\hline Mapk3 & Mitogen activated protein kinase 3 & -1.03 & 0.868 & -1.02 & 0.771 \\
\hline Lipe & Lipase, hormone sensitive & 1.00 & 0.870 & 1.08 & 0.355 \\
\hline Pten & Phosphatase and tensin homolog & 1.22 & 0.240 & 1.06 & 0.757 \\
\hline Inppl1 & Inositol polyphosphate phosphatase-like 1 & -1.08 & 0.563 & -1.01 & 0.947 \\
\hline Ptpn1 & Protein tyrosine phosphatase, non-receptor type 1 & 1.01 & 0.835 & 1.13 & 0.109 \\
\hline
\end{tabular}


Chapter 4

Supplementary Table 1. Q-PCR primer sequences

\begin{tabular}{|c|c|c|c|c|c|}
\hline gene & Refseq & sense primer $\left(5^{\prime}>3^{\prime}\right)$ & antisense primer $\left(5^{\prime}>3^{\prime}\right)$ & $\begin{array}{l}\text { product } \\
\text { length }\end{array}$ & $\mathrm{T}_{\text {annealing }}$ \\
\hline Rps 15 & NM_009091 & cggagatggtgggtagcatgg & acgggtttgtaggtgatggagaac & 118 & $60^{\circ} \mathrm{C}$ \\
\hline Sparc & NM_009242 & gtcctggtcaccttgtacgagag & acatattgtagttcttctcaaagtctcgg & 160 & $60^{\circ} \mathrm{C}$ \\
\hline $\operatorname{Prdx} 1$ & NM_011034 & gctctgtggatgagattatacgactag & ttaagcacgagtagagtacaagagtttc & 220 & $60^{\circ} \mathrm{C}$ \\
\hline$A d n$ & NM_013459 & tcaccattaacatgatgtgtgcagag & ggatgacactcgggtatagacgc & 164 & $60^{\circ} \mathrm{C}$ \\
\hline$C 3$ & NM_009778 & aaagatttcacacaccgaagaagactg & gagcatcccatcgtcettctctg & 160 & $60^{\circ} \mathrm{C}$ \\
\hline Fabp4 & NM_024406 & aatcaccgcagacgacaggaag & tgccetttcataaactcttgtggaag & 178 & $60^{\circ} \mathrm{C}$ \\
\hline Collal & NM_007742 & cagattgagaacatccgcagcc & tgacctgtctccatgttgcagtag & 170 & $60^{\circ} \mathrm{C}$ \\
\hline Colla2 & NM_007743 & gccaacaagcatgtctggttagg & cgagetgagttgccatttcettg & 100 & $60^{\circ} \mathrm{C}$ \\
\hline Col3al & NM_009930 & agaagtctctgaagctgatgggatc & tagtctcattgccttgcgtgtttg & 158 & $60^{\circ} \mathrm{C}$ \\
\hline$S c d 1$ & NM_009127 & tcatggtcctgctgcacttgg & ctgtggctccagaggegatg & 145 & $60^{\circ} \mathrm{C}$ \\
\hline Pnpla2 & NM_025802 & ccagttcaaccttcgcaatctctac & gcatgttggaaagggtggtcatc & 179 & $60^{\circ} \mathrm{C}$ \\
\hline Lipe & NM_010719 & tcagggacagaggcagaggac & tccacttagttccaggaaggagttg & 147 & $60^{\circ} \mathrm{C}$ \\
\hline Ppap2a & NM_008903 & gactcttacgacccatgetccag & agaatgtgtgtccttgaagaaatcgg & 179 & $60^{\circ} \mathrm{C}$ \\
\hline Ppap $2 b$ & NM_080555 & tcacgggtatctgactacaagcatc & gcagtgagaggctcgtcttagtc & 130 & $60^{\circ} \mathrm{C}$ \\
\hline Dgatl & NM_010046 & tccagaactccatgaagcccttc & tgccacagcattgagacaggag & 140 & $60^{\circ} \mathrm{C}$ \\
\hline Dgat2 & NM_026384 & ctatttggctacgttggetggtaac & ttggagagcaagtagtctatggtgtc & 111 & $60^{\circ} \mathrm{C}$ \\
\hline Adfp & NM_007408 & gtccetgtctaccaagctctgc & tggttggcactgtgcatattcttc & 153 & $60^{\circ} \mathrm{C}$ \\
\hline Plin & NM_175640 & ccaggctgtctcctctaccaaag & tcgatgtctcggaattcgctctc & 150 & $60^{\circ} \mathrm{C}$ \\
\hline Cav1 & NM_007616 & agacgaggtgactgagaagcaag & tgtgtgtccettctggttctgc & 140 & $60^{\circ} \mathrm{C}$ \\
\hline$P i k 3 r 2$ & NM_008841 & tcgtgtggetcacccagaaag & gcgtcctcatcctccatcagtg & 106 & $60^{\circ} \mathrm{C}$ \\
\hline $\operatorname{Irs} 2$ & XM_357863 & gccetctgccagcacctatg & cgcttcactctttcacgactgtg & 80 & $60^{\circ} \mathrm{C}$ \\
\hline Serpina $3 c$ & NM_008458 & cttctccaaacaagctgacctatctg & cagactggttcttctactaagaatgcg & 160 & $60^{\circ} \mathrm{C}$ \\
\hline Pparg & NM_011146 & gaagttcaatgcactggaattagatgac & ttgtcttggatgtcctcgatggg & 120 & $60^{\circ} \mathrm{C}$ \\
\hline
\end{tabular}




\section{Chapter 4}

Supplementary Fig. 1. Comparison between microarray and quantitative real time RT-PCR analysis. The mean of the fold change is shown. $n=5$ for array $n=6$ for RT-PCR; The line of 1.3 and -1.3 fold changes was used as threshold of differential expression.

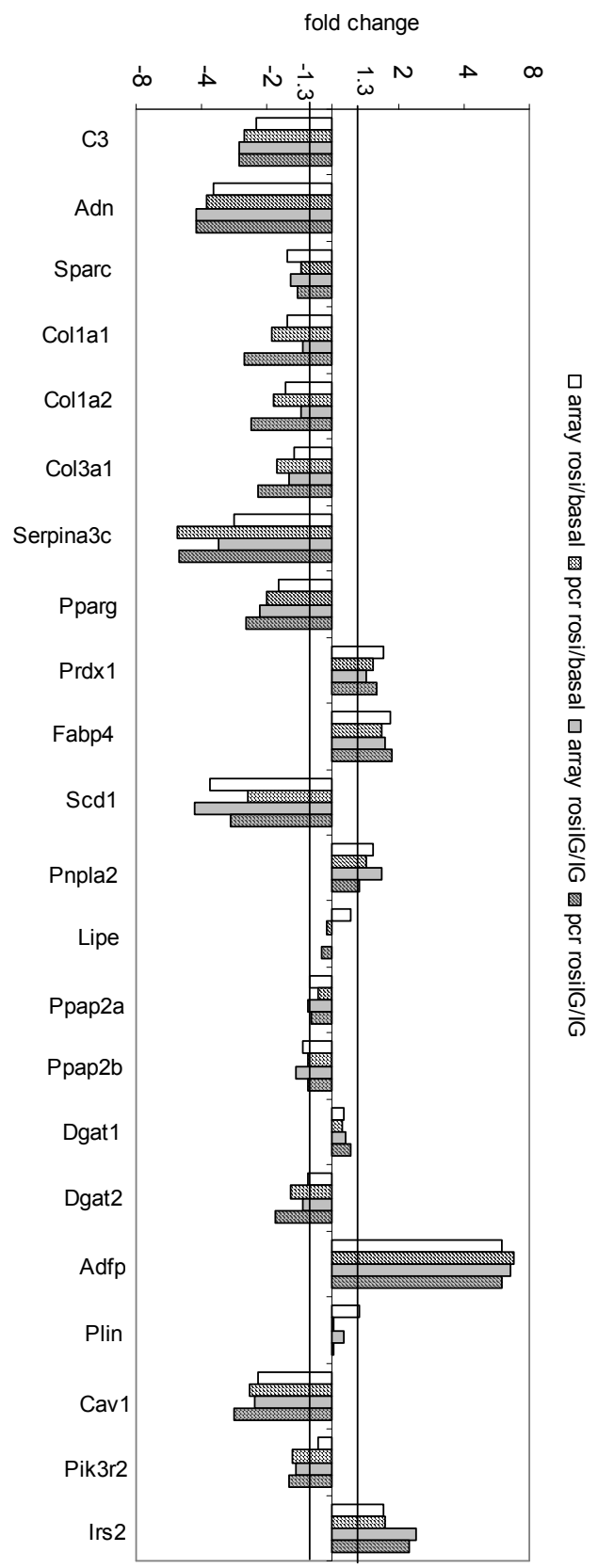


Supplementary materials 


\section{Summary}




\section{Summary}

The physiological function of white adipose tissue is essential for the body, as described in Chapter 1. Adipose tissue consists mainly of fat cells, adipocytes, which exert a protective role in energy homeostasis through their fat-storing capability, and through secreted signal molecules participating in the regulation of the energy balance. Under normal conditions, the adipocytes are able to adjust the metabolism of lipids and the secretion of the signaling molecules to the need of the body. However, the balance can be broken, when adipose tissue mass increases above a certain level. Indeed, obesity and overweight have been recognized by the WHO as a major risk for diet-related chronic diseases, globally. The disturbance of secreted signal molecules from adipocytes and adipose tissue has been implicated in the development of obesity related diseases. A large number of these molecules are proteins. A lot of these proteins have been discovered, but apparently many more are still unknown. There is also much to learn about how these signals function. This thesis describes research employing the murine 3T3-L1 cell model and high-throughput proteomics and transcriptomics to discover new secreted proteins from adipocytes and to study their regulation. This thesis also describes investigations to substantiate a functional role of the novel secreted proteins in humans using epidemiological analysis.

By profiling secreted proteins during 3T3-L1 adipocyte differentiation with a blocking strategy, as described in Chapter 2, novel adipocyte secreted proteins have been identified, especially growth factors. It is also shown that extracellular matrix proteins, mainly composed of collagens, are an important component of the adipocyte secretome.

The secretome of adipocytes is dynamic and can be regulated. This thesis describes the systemic effects of two stimuli, insulin and rosiglitazone. Some of the regulatory mechanisms are revealed by examining the transcriptome.

Insulin, a hormone that is relevant to nutritional status and is also related to insulin resistance and type 2 diabetes, has a significant impact on the secretome of 3T3-L1 adipocytes as described in Chapter 3. It stimulates the secretion of most genuine secreted proteins, while it suppresses cell leakage and protein degradation. By combining transcriptomics and proteomics, it was found that transcription is not the major regulation point for these secreted proteins. For extracellular matrix components, our data suggest that the mRNA level of processing enzymes, but not of target proteins, is the regulation point at which insulin stimulates secretion and processing.

Although being regarded as an 'insulin sensitizer', the drug Rosiglitazone has opposite effects compared to insulin with respect to the secretion of mature 3T3-L1 adipocytes and also with respect to lipid metabolism as described in Chapter 4. Rosiglitazone introduces a general suppression of genes encoding secreted proteins, and a general decrease of the secretion. Meanwhile, a considerable increase in lipid catabolism occurs. These changes are part of the detailed mechanism for the role of this drug in treating type 2 diabetes. We further proposed that there might be a general mechanism connecting energy status of an adipocyte and its secretory activity. 
When proteins secreted from adipocytes need to play a systemic role in the body, blood circulation is one major place to go first. The existence of an association of the circulating levels of these proteins in blood with adiposity and other parameters can verify the link between adipocytes and these proteins, and further suggest a functional role in the body. Two proteins have been studied in this way.

Visfatin is a recently discovered adipocyte-secreted protein that was shown by some to be associated with visceral fat and insulin resistance. However, in non-diabetic Caucasian subjects as described in Chapter 5, its plasma level lacks association with whole body adiposity and visceral fat size, and with insulin resistance, but correlated positively with HDL-cholesterol and negatively with triglycerides. This implies that a role in lipid metabolism may be more related to its real physiological function in humans. The relation to lipid metabolism may be linked to its known enzymatic function in NAD metabolism.

For another novel 3T3-L1 adipocyte secreted protein that was identified in Chapter 2, pigment epithelium-derived factor (PEDF), strong evidence was obtained for it being a true adipocyte secreted protein in humans, by studying both normal and obese subjects as described in Chapter 6. The relation among its plasma level, hypertension and impaired glucose metabolism, shows that PEDF may play a role in the development of obesity related insulin resistance and cardiovascular diseases.

The above studies have generated a view of adipocytes at the system level as discussed in Chapter 7. The secretory function and activity of adipocytes cannot be separated from the intracellular lipid storage and lipid handling function of adipocytes. The adipocytes need to be regarded as a system at the level of a cell. In addition, the secretory function of adipocytes should be regarded at the level of whole body considering organ-organ interactions. 


\section{Samenvatting}

De fysiologie van het vetweefsel is van essentieel belang voor het lichaam, zoals beschreven in Hoofdstuk 1. Vetweefsel bestaat voornamelijk uit vetcellen, adipocyten, die een beschermende invloed uitoefenen op de energie-huishouding vanwege hun eigenschap om vet op te slaan, en daarnaast vanwege het uitscheiden van signaalmoleculen die helpen de energie-balans te regelen. Onder normale omstandigheden zijn de adipocyten in staat om hun lipiden-metabolisme en de mate van uitscheiding van signaal-moleculen aan te passen aan de behoeften van het lichaam. Echter, deze balans kan worden verstoord wanneer de totale massa aan vetweefsel een bepaalde grens overschreidt. Inderdaad heeft de Wereld Gezondheids Organisatie obesitas en overgewicht erkend als een van de voornaamste, wereldwijde risiko's voor het ontstaan van dieet-gerelateerde chronische aandoeningen. De verstoring van de door adipocyten en vetweefsel uitgescheiden signaal-moleculen wordt daarbij beschouwd als een van de factoren die ten grondslag liggen aan de ontwikkeling van obesitas-gerelateerde ziekten. Een groot deel van deze moleculen zijn eiwitten. Inmiddels is er al een heel aantal bekend bekend, maar ongetwijfeld zijn er nog meer te ontdekken. Ook valt er nog veel te leren over de werking van deze moleculen. In dit proefschrift wordt onderzoek beschreven, waarbij het muizen 3T3-L1 celmodel is gebruikt om met behulp van highthroughput proteomics en transcriptomics nieuwe, door adipocyten uitgescheiden eiwitten te identificeren en hun regulatie te bestuderen. Tevens wordt in dit proefschrift onderzoek beschreven waarmee de functionaliteit van nieuw ontdekte uitgescheiden eiwitten in de mens wordt onderbouwd met behulp van epidemiologische analyse.

Door protein-profiling van uitgescheiden eiwitten gedurende de differentiatie van 3T3L1 adipocyten, waarbij een strategisch gebruik is gemaakt secretie-remmende condities, zoals beschreven in Hoofdstuk 2, is een aantal additionele eiwitten geïdentificeerd als factoren die door adipocyten worden uitgescheiden, met name groeifactoren. Ook wordt aangetoond dat eiwitten van de extracellulaire matrix, voornamelijk collagenen, een belangrijk deel uitmaken van het adipocyten-secretoom.

Het adypocyten-secretoom is dynamisch en kan worden beïnvloed. In dit proefschrift worden de systemische effecten van twee stimuli, insuline en rosiglitazone, beschreven. Bepaalde aspecten van het regulatoire mechanisme worden zichtbaar gemaakt door het transcriptoom nader te onderzoeken.

Insuline, een hormoon dat relevant is voor de voedingsstatus en tevens gerelateerd is met insuline-resistentie en type II diabetes, heeft een significante invloed op het secretoom van 3T3-L1 adipocyten, zoals beschreven in Hoofdstuk 3. Het stimuleert de uitscheiding van de meeste eiwitten, terwijl het passieve lekken van eiwitten uit cellen alsmede de afbraak van eiwitten worden onderdrukt. Door transcriptomics en proteomics te combineren werd aangetoond dat de regulatie niet op het niveau ligt van de transcriptie van de genen voor uitgescheiden eiwitten. Nader onderzoek m.b.t. eiwitten van de extracellulaire matrix toont aan, dat veeleer het mRNA van de processing enzymen, en niet van de collagenen zelf, het aangrijpingspunt is voor het stimuleren van eiwit-uitscheiding en -processing door insuline. 
Ofschoon beschouwd als 'insuline sensitizer', induceert het medicijn Rosiglitazone in vergelijking met insuline tegenovergestelde effecten met betrekking tot de eiwituitscheiding en het lipiden-metabolisme van mature 3T3-L1 adipocyten zoals beschreven in Hoofdstuk 4. Rosiglitazone onderdrukt algemeen de activiteit van de genen voor uitgescheiden eiwitten alsmede het proces van de uitscheiding zelf. Tegelijkertijd wordt een aanzienlijke verhoging van de lipiden-afbraak in de cellen waargenomen. Deze veranderingen zijn onderdeel van het gedetailleerde werkingsmechanisme van dit medicijn bij de behandeling van type II diabetes. Meer algemeen geven onze resultaten aan dat de energie-status van de adipocyt en de activiteit van eiwit-uitscheiding onlosmakelijk met elkaar verbonden zijn.

Eiwitten die door adipocyten uitgescheiden worden en een systemische rol vervullen in het lichaam, komen eerst in het bloed terecht. Het vinden van een associatie tussen het circulatoire niveau van een eiwit en adipositeit met de daaraan gerelateerde parameters wijst op een nauwe relatie tussen enerzijds adipocyten en anderzijds het circulerende eiwit, en dit kan worden beschouwd als een aanwijzing voor een functionele rol in het lichaam.

Visfatine is een recent ontdekt adipocyt-gesecreteerd eiwit, waarvan sommigen hebben aangetoond dat het plasma niveau geassocieerd is met het viscerale vet en met insuline resistentie. Echter, in niet-diabete personen van Kaukasische oorsprong, zoals beschreven in Hoofdstuk 5, kon door ons geen associatie worden aangetoond met adipositeit, omvang van het viscerale vet, en insuline resistentie. Echter, wel werd er positieve correlatie gevonden met HDL-cholesterol en een negatieve correlatie met triglyceriden. Dit kan erop duiden dat de fysiologische functie van visfatine in de mens gezocht moet worden in het lipiden-metabolisme. Een dergelijk verband met het lipiden-metabolisme zou kunnen samenhangen met de feitelijke enzymatische functie van het eiwit in het cellulaire NAD metabolisme.

Voor een ander uitgescheiden eiwit, pigment epithelium-derived factor (PEDF), dat werd geidentificeerd in Hoofdstuk 2, werd door vergelijking van de niveaus in normale en obese personen overtuigend aangetoond dat het ook in de mens door adipocyten wordt uitgescheiden zoals beschreven in Hoofdstuk 6. De relatie tussen het plasma niveau, hypertensie en een verstoord glucose metabolisme, geeft aan dat PEDF een rol zou kunnen spelen bij het ontstaan van obesitas-gerelateerde insuline resistentie en harten vaatziekten.

De bovengenoemde studies leiden tot de overweging hoe adipocyten moeten worden beschouwd in het systeem-denken, zoals beschreven in Hoofdstuk 7. De functie en activiteit van adipocyten m.b.t. het uitscheiden van signaal-eiwitten kan niet los worden gezien van de intracellulaire opslag en omzetting van lipiden. Om de resultaten te interpreteren, die uit 'omics'-experimenten zijn verkregen, dienen de adipocyten te worden beschouwd als een systeem op het niveau van de cel. Echter, waar het gaat om uitgescheiden eiwitten met een rol in de communicatie tussen organen, dient het systeem uitgebreid te worden tot het gehele lichaam. 


\section{Acknowledgements}

First of all, I thank the Centre for Human Nutrigenomics (CHN), which is the sponsor of this project. For me, $\mathrm{CHN}$ is not just a name but an organization of which I am proud to be a member. I got to know other scientists and $\mathrm{PhD}$ students in this field quickly through CHN.

I am grateful to the members of Assessment Committee and Supervisory Committee: Prof. Dr. Wim Saris, Prof. Dr. Susanne Klaus, Prof. Dr. Ronald Mensink, Prof. Dr. Michael Müller, Prof. Dr. Frederik-Jan van Schooten, Prof. Dr. Peter Verhaert and Dr. Ben van Ommen for your time and effort to critically evaluate this thesis.

Edwin, you are far more than a promotor and daily supervisor to me. You are my guide and friend in science and life. Each step of my progress has your effort. I am short of words to express my gratefulness to you for leading me to this stage of my life, in which I see my power and find joy and peace. I know that my 'hot' temper is quite in contrast to your modest temper. Thank God, we still can work together so well. I take it as fun to 'quarrel' with you in our discussions, for solving problems and generating ideas. May this fun last beyond this time.

Jaap, you are also so important to me. Your enthusiasm for science deeply touched me. I really enjoyed the time every Thursday afternoon in Rikilt, when we had work discussions. You always encouraged me to try, to go further bravely. You not only taughter me how to do research, but also how to be a good scientist. The finish of this $\mathrm{PhD}$ project does not mean an end of our friendship. We all know that in the future we will find the pleasure again in working together.

Johan, thanks for being there as my daily supervisor at the start of my research and keep on till the last for my thesis. You always looked positively on me and encouraged me. Sometimes I was maybe a little stubborn, but your help and support are appreciated in heart.

I stayed with the Functional Genomics (FunGen) group for three years in the PhD project and will continue to stay for another three-year period for my post-doc. I am glad to have you all as my colleagues and friends. Thanks to you all FunGen members for technical support, useful discussions and friendly care. Some special points need to be mentioned: Freek, you are the real master in this big family. Besides your excellent technical work in this project, I thank you also for teaching me all the techniques in proteomics and managing my project account. Egbert, thanks for working together with me, especially in the later stage of my study, also thanks to your family for the special kindness. Kaatje, you were the key person to let me choose this $\mathrm{PhD}$ position. Thanks for helping me make this decision, also thanks for help in passing through this final 
graduation procedure. Ronny, thanks for being my roommates. You always gave me positive responses. Geert, thanks for being so kind to me. It is great we can share the passion for science. Jonathan, thanks for teaching me in the lab and finding out the problem of my computer. Janneke and Nicole, thanks for joining the female force in the group.

Also I thank people in the department of Human Biology who are so kind to me, especially Jos for always accompanying me on weekends in the corridor; Antoine, Herman, Rene, Esther (Kornips), Sander, Gijs, Joan and Arjen (now in the Dept. Molecular Genetics), for the useful help and discussions for the work; Hasibe and Andera for being my roommates; Claudia, Larisa and Ilona for taking care of my general situation; Loek and Paul for the computer support; Mandy, Wouter, Cheryl, Eefje, Margriet and Klaas for special kindness and invitations.

I really enjoyed my year in Rikilt and I am glad to see my relation with my colleagues and friends there is lasting. I deeply appreciate the super-well-organized labs and the groups in Rikilt, especially the Food Bioactives (BS) group. I would like to mention some special points of you: Annelies, besides the excellent technical support in this project, also thanks for teaching me techniques in microarray analysis and caring me at work and life. Wendy, you showed your great generous mind in passing your knowledge on data processing to the group, including me, thanks for spending time in teaching me programms. Eveline, you helped me start the first experiment in Rikilt on cDNA synthesis. Jos, you taught me how to design primers. Marjolein, with Annelies and Eveline, you took good care of the lab to make sure that it runs smoothly. Together with Tona, Thomas, Vasileios and Caroline, you all made up a very nice and funny big office group. Let me miss you now and then. Vincent, you were helpful not only on computer and web, but also direct in experiment. Thanks for the setting up the metabolites assay, enable me to finish my work in time. Esther, thank you for teaching me how to isolate RNA. Also it was very touching in attending your wedding in Church, with all English translations. Marjorie, thanks for helping the cell culture, although we did not go further on that part. Yvonne (Dommels), Gera, Linette, Evert, Nicole, Ilija and Peter, thanks for your ideas in work discussions and support in the group.

Also thanks to other people in Rikilt: Robert, for your support to the group; Jeroen, for your thorough discussions with me on PCR, Ruud and Jan, for your network support. So many familiar faces showed their kindness to me, I am sorry to stop here. But I am really grateful to all the people so friendly to me in Rikilt.

The work in this thesis also included efforts from others groups: Jean-Paul, Erik and Johan of the Proteomics Facilities of Hasselt Univeristy, thanks for your excellent work on LC-MS/MS protein identification. Marleen, Carla and Martijn of the Department of Internal Medicine, thanks for letting me using the samples of FCHL cohort, and teaching me so much on association studies. Vicky, thanks for all the technical help in the lab. Jos and Frederik of the Department of Molecular Cell Biology, thanks for 
accepting my sudden request for using fluoresces cofocal microscopy and spending time in teaching me the techniques. Chris, Martijn, Magali and Michiel of the Big Cat Group, thanks for the excellent work on GenMapp fatty acid pathways. Will and Marja of the Department of Clinical Chemistry, Thanks for the accurate work on high inflamed subjects and hsCRP assay.

I thank other friends beyond my work for your support and help in life during this period. Zhu Yang and Kuang Yi-hua, thanks for introducing me to the Netherlands and taking care of me as a family member. Feng $\mathbf{L i}$, thanks for your deep understanding and friendship from Australia. Michel, I am glad to meet you almost every Sunday in Randwyck. Thanks to you and Francisca for showing me the nice art works. Sun Jingjing, Ren Xin-ying, Du Hai-dong, Yee and Gabriele, my friends in Wageningen, thanks for treating me so kindly when I stayed and visited Wageningen. I really enjoyed the cozy moments we shared together. Qi Shu-fan, Bai Li-li, Li You-nan, Weng Lin and Wu Ya-qian, it was nice to know you in our Chinese Network of Life Science Maastricht branch. Thanks for all your friendship. Sabine, thanks for taking care of my room when I was in Wageningen.

Finally, I thank my family for all your sacrifice, support and love. Dear father and mother, thanks for giving me life and let me be the one I like to be. You set me free to be here and carry the loneliness at home. All this I can feel. A Hui, my dear sister, thanks for taking good care of the parents, and charging me every week with your supportive call. Tao Yu-wei and Tao Yu-qi, my lovely twin nieces, thanks for bringing me lots of fun and cheering me up. Dear grandparents, if I had known that my leaving would cost your lives, I would have given up the chance to go abroad. This deep pain will be with me forever. Hope your souls are in peace and joy watching me today.

最后, 我感谢我的家人为我的牺牲, 给我的支持和爱。亲爱的爸爸妈妈, 感谢你们生我养我。你们给了我自由, 去过我想要的生活。我知道为此你 们承受了子女不在身边的失落。阿蕙, 亲爱的妹妹, 感谢你照顾父母, 以 免我后顾之忧。每个星期和你的通话, 都是在精神上给我充电。陶予玮 和陶予琦, 我可爱的外甥女们, 感谢你们给我带来的欢乐。亲爱的外公外 婆, 如果我能预见你们会因我的离开而逝去, 我不会出国来。此痛将随我 一生。愿你们在天之灵为我的现在感到欣慰。

1 January 2007, in Maastricht 


\section{Publications}

1. Wang P, Cai RR, Feng YM, Zhang YS. (2000) Studies on insulin/IGF-1 hybrid and IGF-1 growth-promoting functional region.

IUBMB Life. 49(4):321-5.

2. Wang P, Mariman E, Keijer J, Bouwman F, Noben JP, Robben J, Renes J. (2004) Profiling of the secreted proteins during 3T3-L1 adipocyte differentiation leads to the identification of novel adipokines.

Cell Mol Life Sci. 61(18):2405-17.

3. Wang P, Keijer J, Bunschoten A, Bouwman F, Renes J, Mariman E. (2006) Insulin modulates the secretion of proteins from mature 3T3-L1 adipocytes: a role for transcriptional regulation of processing.

Diabetologia. 49(10):2453-62.

4. Wang P, Renes J, Bouwman F, Bunschoten A, Mariman E, Keijer J. (2007) Absence of an adipogenic effect of rosiglitazone on mature 3T3-L1 adipocytes: increase of lipid catabolism and reduction of adipokine expression.

Diabetologia. In press

5. Wang P, van Greevenbroek M, Bouwman F, Brouwers M, van der Kallen C, Smit E, Keijer J, Mariman E. The circulating PBEF/NAMPT/visfatin level is associated with a beneficial blood lipid profile.

Submitted

6. Smit E, Wang P, Goossens G, Kruishoop M, van Baak M, Blaak E, van der Kallen C, van Greevenbroek M, Feskens E, Brouwers M, Mariman E. Pigment epithelium-derived factor, a potent anti-angiogenic factor and newly identified adipokines, is associated with obesity, hypertension and impaired glucose metabolism in humans.

Submitted 


\section{Curriculum Vitae}

Ping Wang was born in Shanghai, China on 27 April 1970. She studied Food Science and Technology at the East China University of Sciences and Technology in Shanghai from 1988 to 1992, and graduated as a Bachelor of Engineering with distinction. Afterwards she worked as an analyst and later also as administrator assistant in Shanghai Cereal and Oil Products Quality Supervision and Testing Center of Chinese Ministry of Internal Trade, located in Shanghai Cereal Sciences Institute until 1995, when she went back to the mother university to be a master student. From 1996 to 1998 she got her practical training in the State Key Laboratory of Molecular Biology in Shanghai Institute of Biochemistry, Chinese Academia of Sciences. She worked on the protein engineering and biological analysis of an insulin / IGF-1 hybrid. Based on that work, she graduated as a Master of Science in Biochemistry in July 1998. After a short working period at SGS-CSTC Standards Technical Services Co. Ltd. Shanghai Branch, she worked on functional food supplements in the Department of Technology Development at Lipsun Bioproducts Company for two years. From August 2000, She moved from Shanghai to the Netherlands. At Wageningen University she studied Agrofood and Bioprocess Technology and got her practical training on soybean protein hydrolysates in the Department of Technology Development and Quality at Numico Research Co. She graduated as a Master of Science with distinction in Biotechnology in January 2002. After graduation she worked as a PhD student first in the Department of Lipid Biochemistry at Utrecht University, then found her ultimate $\mathrm{PhD}$ position in the Department of Human Biology, Maastricht University at the end of 2002. In this PhD research project of the Centre for Human Nutrigenomics, she worked as well in the Group of Food Bioactives at Rikilt-Institute of Food Safety, Wageningen. After finishing her thesis on the secreted proteins from adipocytes, she was appointed as a postdoc from January 2007 on the DioGenes European project on diet, obesity and genes. 
